\title{
Modeling Enclosure Design in Above-Grade Walls
}

J. Lstiburek, K. Ueno, and S. Musunuru Building Science Corporation

March 2016 


\section{NOTICE}

This report was prepared as an account of work sponsored by an agency of the United States government. Neither the United States government nor any agency thereof, nor any of their employees, subcontractors, or affiliated partners makes any warranty, express or implied, or assumes any legal liability or responsibility for the accuracy, completeness, or usefulness of any information, apparatus, product, or process disclosed, or represents that its use would not infringe privately owned rights. Reference herein to any specific commercial product, process, or service by trade name, trademark, manufacturer, or otherwise does not necessarily constitute or imply its endorsement, recommendation, or favoring by the United States government or any agency thereof. The views and opinions of authors expressed herein do not necessarily state or reflect those of the United States government or any agency thereof.

Available electronically at SciTech Connect http:/www.osti.gov/scitech

Available for a processing fee to U.S. Department of Energy

and its contractors, in paper, from:

U.S. Department of Energy

Office of Scientific and Technical Information

P.O. Box 62

Oak Ridge, TN 37831-0062

OSTI http://www.osti.gov

Phone: 865.576.8401

Fax: 865.576.5728

Email: reports@osti.gov

Available for sale to the public, in paper, from:

U.S. Department of Commerce

National Technical Information Service

5301 Shawnee Road

Alexandria, VA 22312

NTIS http://www.ntis.gov

Phone: 800.553 .6847 or 703.605 .6000

Fax: 703.605.6900

Email: orders@ntis.gov 


\title{
Modeling Enclosure Design in Above-Grade Walls
}

\author{
Prepared for:
}

The National Renewable Energy Laboratory

On behalf of the U.S. Department of Energy's Building America Program

Office of Energy Efficiency and Renewable Energy

15013 Denver West Parkway

Golden, CO 80401

NREL Contract No. DE-AC36-08GO28308

Prepared by:

J. Lstiburek, K. Ueno, and S. Musunuru

Building Science Corporation

3 Lan Drive, Suite 102

Westford, MA 01886

NREL Technical Monitor: Stacey Rothgeb

Prepared under Subcontract No. KNDJ-0-40337-05

March 2016 
The work presented in this report does not represent performance of any product relative to regulated minimum efficiency requirements.

The laboratory and/or field sites used for this work are not certified rating test facilities. The conditions and methods under which products were characterized for this work differ from standard rating conditions, as described.

Because the methods and conditions differ, the reported results are not comparable to rated product performance and should only be used to estimate performance under the measured conditions. 


\section{Contents}

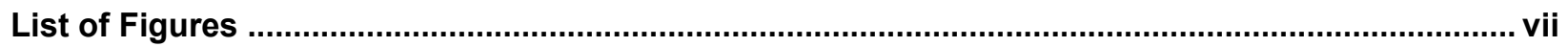

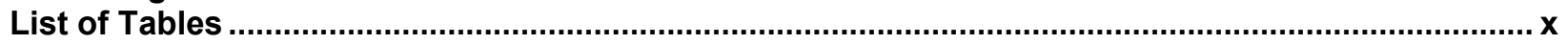

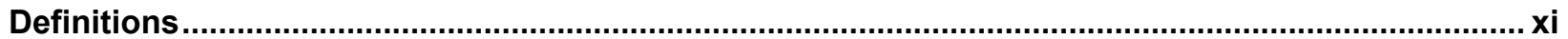

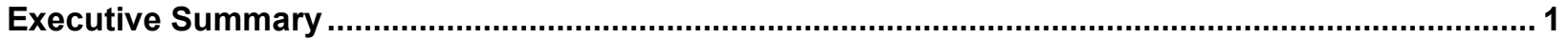

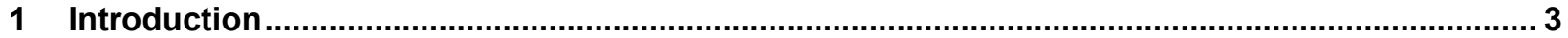

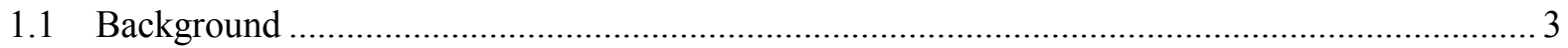

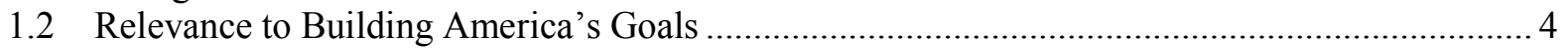

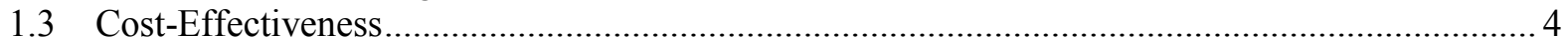

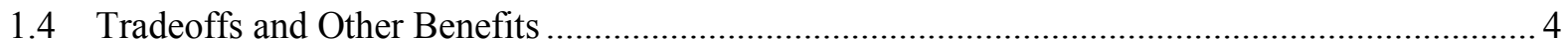

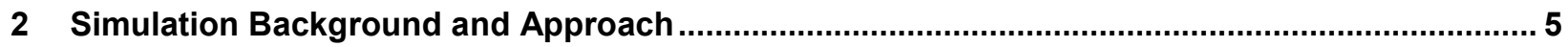

2.1 Model Calibration, Failure Criteria, and Wall Selection........................................................... 5

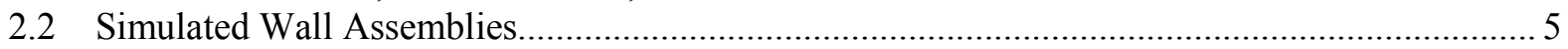

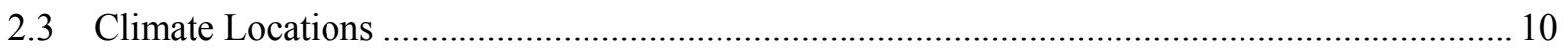

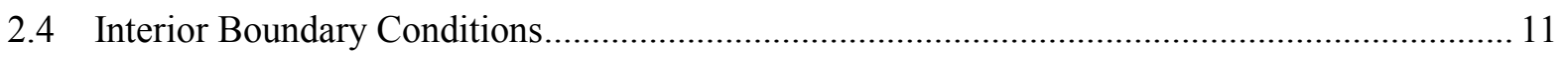

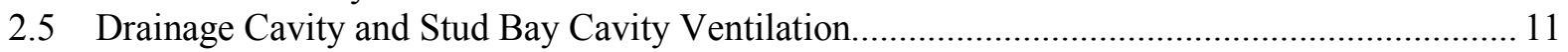

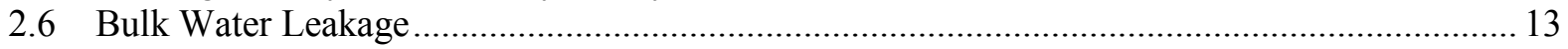

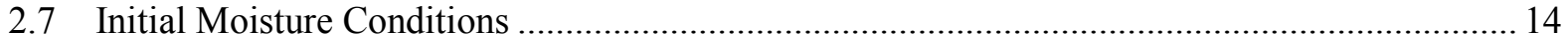

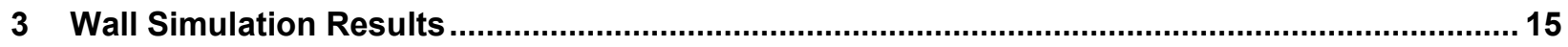

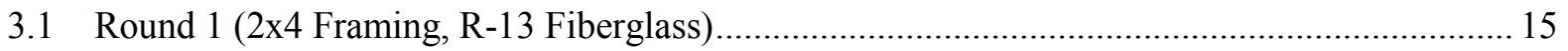

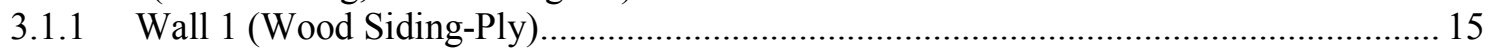

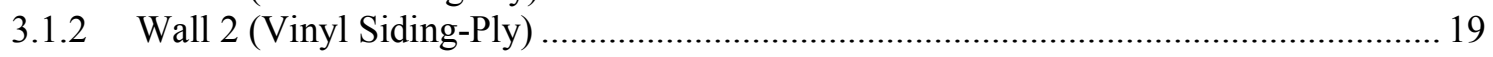

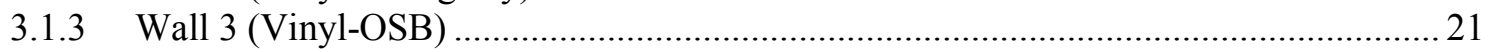

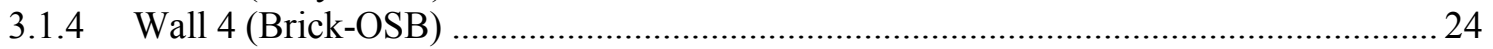

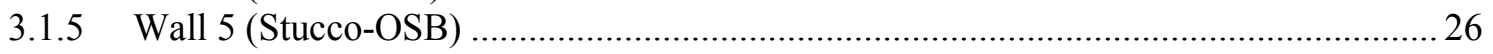

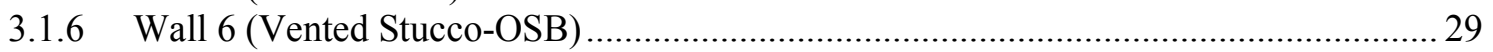

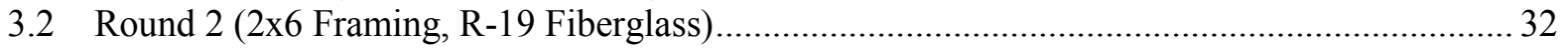

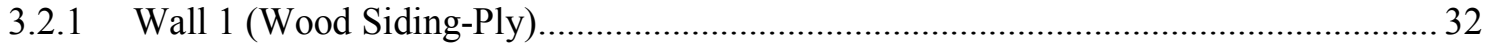

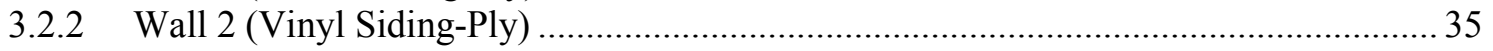

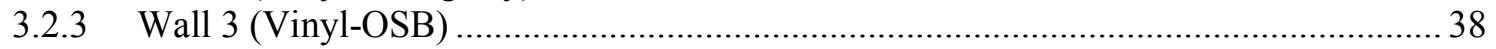

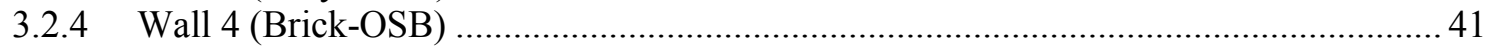

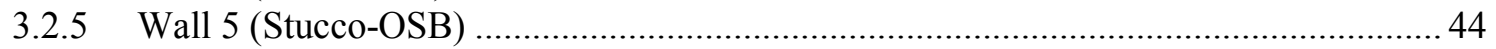

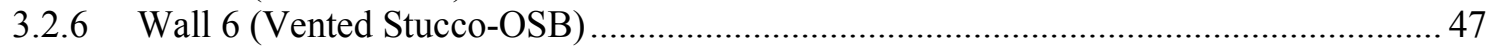

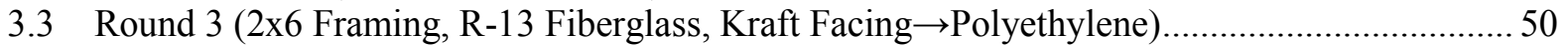

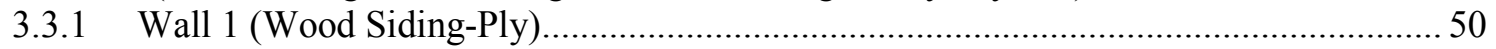

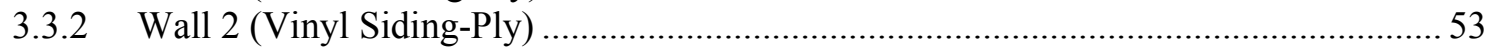

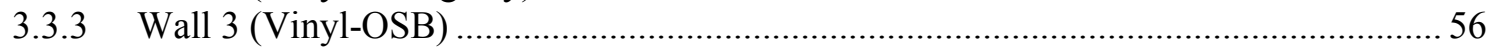

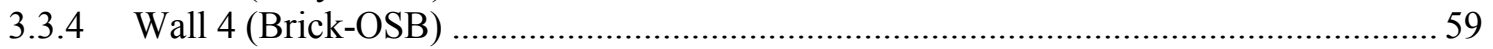

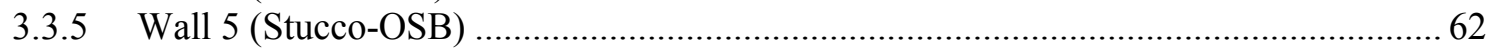

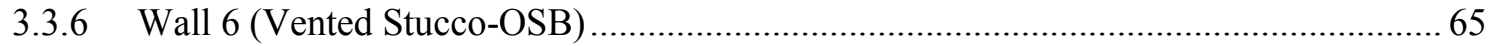

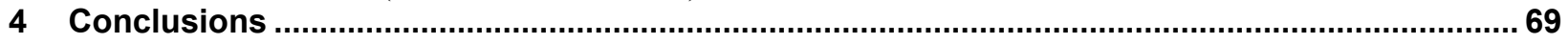

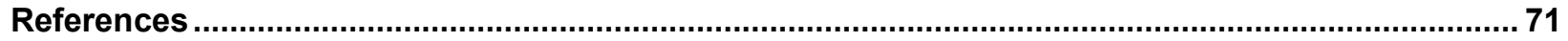

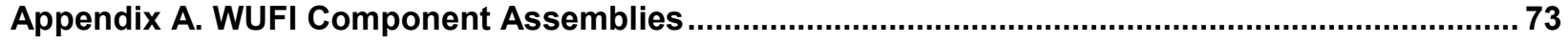

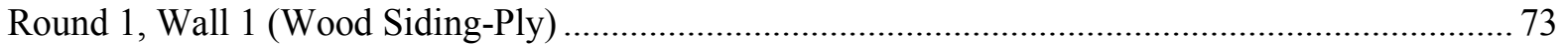

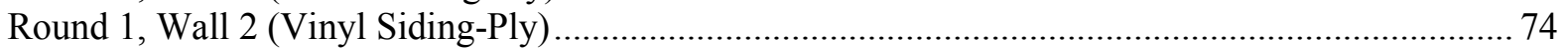

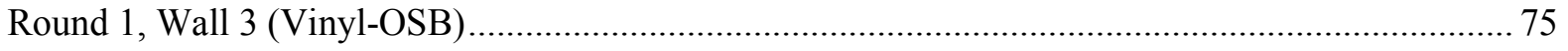

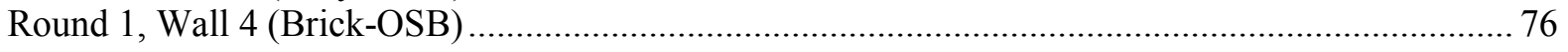

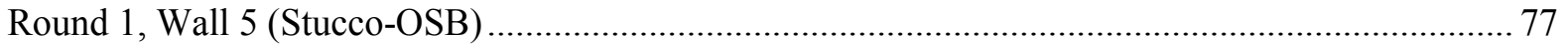

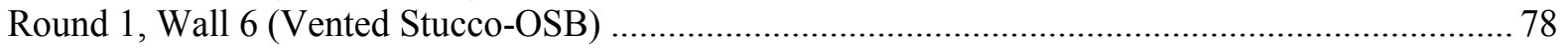

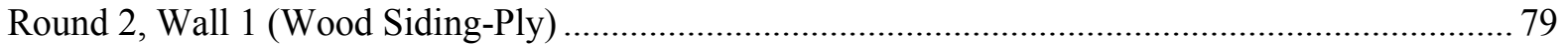

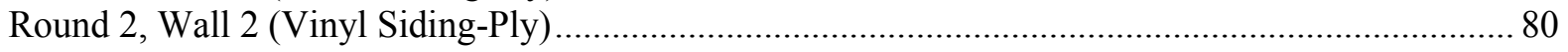


Round 2, Wall 3 (Vinyl-OSB)

Round 2, Wall 4 (Brick-OSB)

Round 2, Wall 5 (Stucco-OSB)

Round 2, Wall 6 (Vented Stucco-OSB)

Round 3, Wall 1 (Wood Siding-Ply)

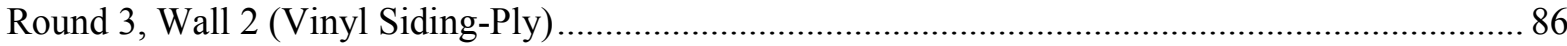

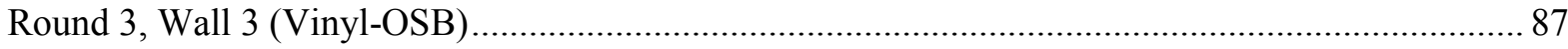

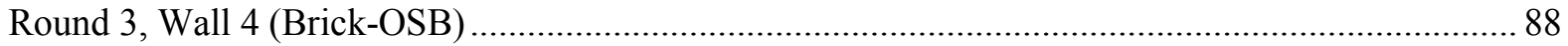

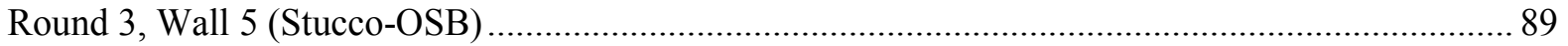

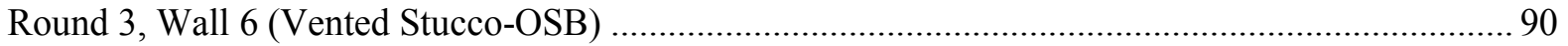

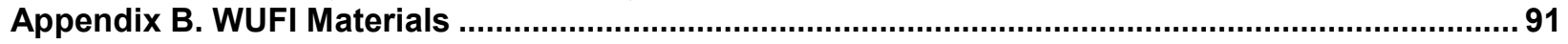

Appendix C. WUFI Surface Transfer Coefficients ….................................................................. 107

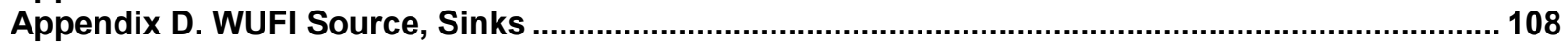

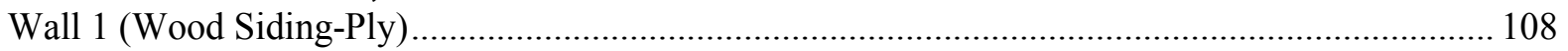

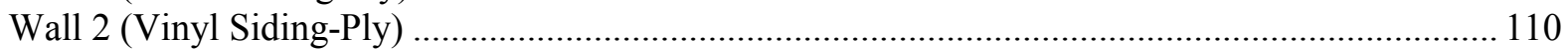

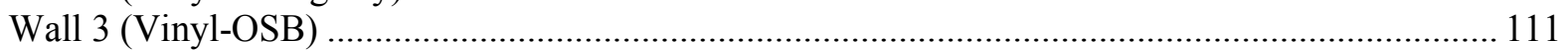

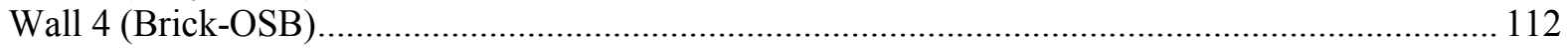

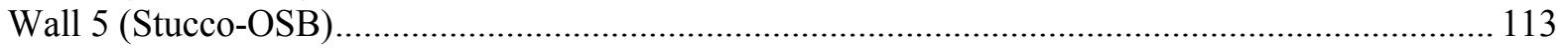

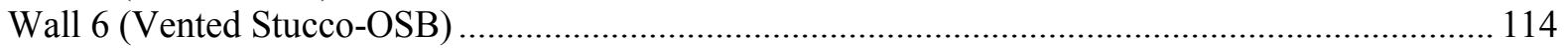




\section{List of Figures}

Figure 1. DOE climate zone map with simulated cities highlighted.

Figure 2. Interior temperature and relative humidity boundary conditions for Chicago (left) and Seattle

(right)

\section{1}

Figure 3. WUFI cross section (Round 1, Wall 3) showing ventilation air spaces ..................................... 12

Figure 4. WUFI exterior surface boundary conditions, rain adhesion highlighted................................ 13

Figure 5. WUFI cross section (Round 1, Wall 1) showing moisture source/sink terms ........................... 13

Figure 6. WUFI cross section (Round 1, Wall 1) showing sheathing MC of the interior layer................. 15

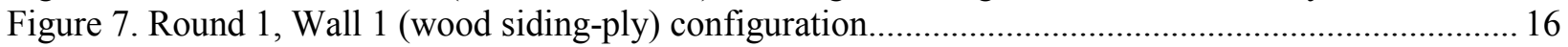

Figure 8. Round 1, Wall 1 sheathing MC in Houston (Zone 2A), north (left) and south (right) ............... 17

Figure 9. Round 1, Wall 1 sheathing MC in Atlanta (Zone 3A), north (left) and south (right)................ 17

Figure 10. Round 1, Wall 1 sheathing MC in Kansas City (Zone 4A), north (left) and south (right) ........ 17

Figure 11. Round 1, Wall 1 sheathing MC in Seattle (Zone 4C), north (left) and south (right) ................. 18

Figure 12. Round 1, Wall 1 sheathing MC in Chicago (Zone 5A), north (left) and south (right) ............. 18

Figure 13. Round 1, Wall 1 sheathing MC in Minneapolis (Zone 6A), north (left) and south (right)........ 18

Figure 14. Round 1, Wall 2 (vinyl siding-ply) configuration .............................................................. 19

Figure 15. Round 1, Wall 2 sheathing MC in Houston (Zone 2A), north (left) and south (right) .............. 20

Figure 16. Round 1, Wall 2 sheathing MC in Atlanta (Zone 3A), north (left) and south (right)............... 20

Figure 17. Round 1, Wall 2 sheathing MC in Kansas City (Zone 4A), north (left) and south (right) ........ 20

Figure 18. Round 1, Wall 2 sheathing MC in Seattle (Zone 4C), north (left) and south (right)................ 20

Figure 19. Round 1, Wall 2 sheathing MC in Chicago (Zone 5A), north (left) and south (right) ............. 21

Figure 20. Round 1, Wall 2 sheathing MC in Minneapolis (Zone 6A), north (left) and south (right)........ 21

Figure 21. Round 1, Wall 3 (Vinyl-OSB) configuration .................................................................... 22

Figure 22. Round 1, Wall 3 sheathing MC in Houston (Zone 2A), north (left) and south (right)............. 22

Figure 23. Round 1, Wall 3 sheathing MC in Atlanta (Zone 3A), north (left) and south (right)................ 22

Figure 24. Round 1, Wall 3 sheathing MC in Kansas City (Zone 4A), north (left) and south (right) ........ 23

Figure 25. Round 1, Wall 3 sheathing MC in Seattle (Zone 4C), north (left) and south (right)................. 23

Figure 26. Round 1, Wall 3 sheathing MC in Chicago (Zone 5A), north (left) and south (right) .............. 23

Figure 27. Round 1, Wall 3 sheathing MC in Minneapolis (Zone 6A), north (left) and south (right)........ 23

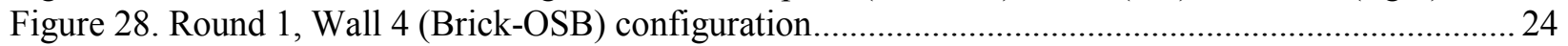

Figure 29. Round 1, Wall 4 sheathing MC in Houston (Zone 2A), north (left) and south (right)............. 25

Figure 30. Round 1, Wall 4 sheathing MC in Atlanta (Zone 3A), north (left) and south (right)............... 25

Figure 31. Round 1, Wall 4 sheathing MC in Kansas City (Zone 4A), north (left) and south (right) ........ 25

Figure 32. Round 1, Wall 4 sheathing MC in Seattle (Zone 4C), north (left) and south (right)................ 25

Figure 33. Round 1, Wall 4 sheathing MC in Chicago (Zone 5A), north (left) and south (right) .............. 26

Figure 34. Round 1, Wall 4 sheathing MC in Minneapolis (Zone 6A), north (left) and south (right)........ 26

Figure 35. Round 1, Wall 5 (Stucco-OSB) configuration.................................................................... 27

Figure 36. Round 1, Wall 5 sheathing MC in Houston (Zone 2A), north (left) and south (right) .............. 27

Figure 37. Round 1, Wall 5 sheathing MC in Atlanta (Zone 3A), north (left) and south (right)............... 27

Figure 38. Round 1, Wall 5 sheathing MC in Kansas City (Zone 4A), north (left) and south (right) ........ 28

Figure 39. Round 1, Wall 5 sheathing MC in Seattle (Zone 4C), north (left) and south (right)............... 28

Figure 40. Round 1, Wall 5 sheathing MC in Chicago (Zone 5A), north (left) and south (right) ............. 28

Figure 41. Round 1, Wall 5 sheathing MC in Minneapolis (Zone 6A), north (left) and south (right)........ 29

Figure 42. Round 1, Wall 6 (vented stucco-OSB) configuration............................................................. 30

Figure 43. Round 1, Wall 6 sheathing MC in Houston (Zone 2A), north (left) and south (right)............. 30

Figure 44. Round 1, Wall 6 sheathing MC in Atlanta (Zone 3A), north (left) and south (right)................ 30

Figure 45. Round 1, Wall 6 sheathing MC in Kansas City (Zone 4A), north (left) and south (right) ........ 31

Figure 46. Round 1, Wall 6 sheathing MC in Seattle (Zone 4C), north (left) and south (right) ................. 31

Figure 47. Round 1, Wall 6 sheathing MC in Chicago (Zone 5A), north (left) and south (right) .............. 31

Figure 48. Round 1, Wall 6 sheathing MC in Minneapolis (Zone 6A), north (left) and south (right)........ 32 
Figure 49. Round 2, Wall 1 (wood siding-ply) configuration.

Figure 50. Round 2, Wall 1 sheathing MC in Houston (Zone 2A), north (left) and south (right) ............. 33

Figure 51. Round 2, Wall 1 sheathing MC in Atlanta (Zone 3A), north (left) and south (right)............... 33

Figure 52. Round 2, Wall 1 sheathing MC in Kansas City (Zone 4A), north (left) and south (right) ........ 34

Figure 53. Round 2, Wall 1 sheathing MC in Seattle (Zone 4C), north (left) and south (right)................ 34

Figure 54. Round 2, Wall 1 sheathing MC in Chicago (Zone 5A), north (left) and south (right) .............. 34

Figure 55. Round 2, Wall 1 sheathing MC in Minneapolis (Zone 6A), north (left) and south (right)........ 35

Figure 56. Round 2, Wall 2 (vinyl siding-ply) configuration .......................................................... 36

Figure 57. Round 2, Wall 2 sheathing MC in Houston (Zone 2A), north (left) and south (right) .............. 36

Figure 58. Round 2, Wall 2 sheathing MC in Atlanta (Zone 3A), north (left) and south (right)............... 36

Figure 59. Round 2, Wall 2 sheathing MC in Kansas City (Zone 4A), north (left) and south (right) ........ 37

Figure 60. Round 2, Wall 2 sheathing MC in Seattle (Zone 4C), north (left) and south (right)................ 37

Figure 61. Round 2, Wall 2 sheathing MC in Chicago (Zone 5A), north (left) and south (right) .............. 37

Figure 62. Round 2, Wall 2 sheathing MC in Minneapolis (Zone 6A), north (left) and south (right)....... 38

Figure 63. Round 2, Wall 3 (Vinyl-OSB) configuration ..................................................................... 39

Figure 64. Round 2, Wall 3 sheathing MC in Houston (Zone 2A), north (left) and south (right) ............. 39

Figure 65. Round 2, Wall 3 sheathing MC in Atlanta (Zone 3A), north (left) and south (right)................ 39

Figure 66. Round 2, Wall 3 sheathing MC in Kansas City (Zone 4A), north (left) and south (right) ........ 40

Figure 67. Round 2, Wall 3 sheathing MC in Seattle (Zone 4C), north (left) and south (right) ................. 40

Figure 68. Round 2, Wall 3 sheathing MC in Chicago (Zone 5A), north (left) and south (right) ............. 40

Figure 69. Round 2, Wall 3 sheathing MC in Minneapolis (Zone 6A), north (left) and south (right)....... 41

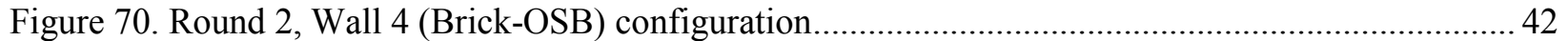

Figure 71. Round 2, Wall 4 sheathing MC in Houston (Zone 2A), north (left) and south (right) ............. 42

Figure 72. Round 2, Wall 4 sheathing MC in Atlanta (Zone 3A), north (left) and south (right).............. 42

Figure 73. Round 2, Wall 4 sheathing MC in Kansas City (Zone 4A), north (left) and south (right) ........ 43

Figure 74. Round 2, Wall 4 sheathing MC in Seattle (Zone 4C), north (left) and south (right)............... 43

Figure 75. Round 2, Wall 4 sheathing MC in Chicago (Zone 5A), north (left) and south (right) ............. 43

Figure 76. Round 2, Wall 4 sheathing MC in Minneapolis (Zone 6A), north (left) and south (right)....... 44

Figure 77. Round 2, Wall 5 (Stucco-OSB) configuration..................................................................... 45

Figure 78. Round 2, Wall 5 sheathing MC in Houston (Zone 2A), north (left) and south (right) ............. 45

Figure 79. Round 2, Wall 5 sheathing MC in Atlanta (Zone 3A), north (left) and south (right)............... 45

Figure 80. Round 2, Wall 5 sheathing MC in Kansas City (Zone 4A), north (left) and south (right) ........ 46

Figure 81. Round 2, Wall 5 sheathing MC in Seattle (Zone 4C), north (left) and south (right)................ 46

Figure 82. Round 2, Wall 5 sheathing MC in Chicago (Zone 5A), north (left) and south (right) ............. 46

Figure 83. Round 2, Wall 5 sheathing MC in Minneapolis (Zone 6A), north (left) and south (right)....... 47

Figure 84. Round 2, Wall 6 (Vented Stucco-OSB) configuration ...................................................... 48

Figure 85. Round 2, Wall 6 sheathing MC in Houston (Zone 2A), north (left) and south (right) .............. 48

Figure 86. Round 2, Wall 6 sheathing MC in Atlanta (Zone 3A), north (left) and south (right)............... 48

Figure 87. Round 2, Wall 6 sheathing MC in Kansas City (Zone 4A), north (left) and south (right) ........ 49

Figure 88. Round 2, Wall 6 sheathing MC in Seattle (Zone 4C), north (left) and south (right)............... 49

Figure 89. Round 2, Wall 6 sheathing MC in Chicago (Zone 5A), north (left) and south (right) ............. 49

Figure 90. Round 2, Wall 6 sheathing MC in Minneapolis (Zone 6A), north (left) and south (right)........ 50

Figure 91. Round 3, Wall 1 (Wood Siding-Ply) configuration............................................................. 51

Figure 92. Round 3, Wall 1 sheathing MC in Houston (Zone 2A), north (left) and south (right) ............. 51

Figure 93. Round 3, Wall 1 sheathing MC in Atlanta (Zone 3A), north (left) and south (right)............... 51

Figure 94. Round 3, Wall 1 sheathing MC in Kansas City (Zone 4A), north (left) and south (right) ........ 52

Figure 95. Round 3, Wall 1 sheathing MC in Seattle (Zone 4C), north (left) and south (right)................ 52

Figure 96. Round 3, Wall 1 sheathing MC in Chicago (Zone 5A), north (left) and south (right) ............. 52

Figure 97. Round 3, Wall 1 sheathing MC in Minneapolis (Zone 6A), north (left) and south (right)....... 53

Figure 98. Round 3, Wall 2 (Vinyl Siding-Ply) configuration ......................................................... 54

Figure 99. Round 3, Wall 2 sheathing MC in Houston (Zone 2A), north (left) and south (right) .............. 54 
Figure 100. Round 3, Wall 2 sheathing MC in Atlanta (Zone 3A), north (left) and south (right).....

Figure 101. Round 3, Wall 2 sheathing MC in Kansas City (Zone 4A), north (left) and south (right) ...... 55

Figure 102. Round 3, Wall 2 sheathing MC in Seattle (Zone 4C), north (left) and south (right).............. 55

Figure 103. Round 3, Wall 2 sheathing MC in Chicago (Zone 5A), north (left) and south (right) ............ 55

Figure 104. Round 3, Wall 2 sheathing MC in Minneapolis (Zone 6A), north (left) and south (right)...... 56

Figure 105. Round 3, Wall 3 (Vinyl-OSB) configuration ................................................................. 57

Figure 106. Round 3, Wall 3 sheathing MC in Houston (Zone 2A), north (left) and south (right) ............5 57

Figure 107. Round 3, Wall 3 sheathing MC in Atlanta (Zone 3A), north (left) and south (right)............. 57

Figure 108. Round 3, Wall 3 sheathing MC in Kansas City (Zone 4A), north (left) and south (right) ...... 58

Figure 109. Round 3, Wall 3 sheathing MC in Seattle (Zone 4C), north (left) and south (right) .............. 58

Figure 110. Round 3, Wall 3 sheathing MC in Chicago (Zone 5A), north (left) and south (right) ............ 58

Figure 111. Round 3, Wall 3 sheathing MC in Minneapolis (Zone 6A), north (left) and south (right)..... 59

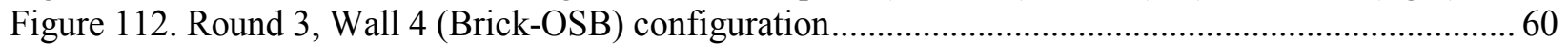

Figure 113. Round 3, Wall 4 sheathing MC in Houston (Zone 2A), north (left) and south (right) ............ 60

Figure 114. Round 3, Wall 4 sheathing MC in Atlanta (Zone 3A), north (left) and south (right).............. 60

Figure 115. Round 3, Wall 4 sheathing MC in Kansas City (Zone 4A), north (left) and south (right) ...... 61

Figure 116. Round 3, Wall 4 sheathing MC in Seattle (Zone 4C), north (left) and south (right).............. 61

Figure 117. Round 3, Wall 4 sheathing MC in Chicago (Zone 5A), north (left) and south (right) ............ 61

Figure 118. Round 3, Wall 4 sheathing MC in Minneapolis (Zone 6A), north (left) and south (right)...... 62

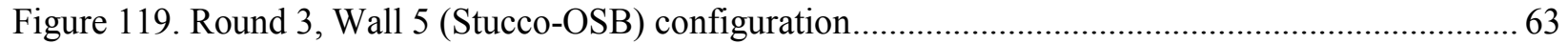

Figure 120. Round 3, Wall 5 sheathing MC in Houston (Zone 2A), north (left) and south (right) ............ 63

Figure 121. Round 3, Wall 5 sheathing MC in Atlanta (Zone 3A), north (left) and south (right)............ 63

Figure 122. Round 3, Wall 5 sheathing MC in Kansas City (Zone 4A), north (left) and south (right) ...... 64

Figure 123. Round 3, Wall 5 sheathing MC in Seattle (Zone 4C), north (left) and south (right).............. 64

Figure 124. Round 3, Wall 5 sheathing MC in Chicago (Zone 5A), north (left) and south (right) ............ 64

Figure 125. Round 3, Wall 5 sheathing MC in Minneapolis (Zone 6A), north (left) and south (right)...... 65

Figure 126. Round 3, Wall 6 (Vented Stucco-OSB) configuration ...................................................... 66

Figure 127. Round 3, Wall 6 sheathing MC in Houston (Zone 2A), north (left) and south (right) ............ 66

Figure 128. Round 3, Wall 6 sheathing MC in Atlanta (Zone 3A), north (left) and south (right)............. 66

Figure 129. Round 3, Wall 6 sheathing MC in Kansas City (Zone 4A), north (left) and south (right) ...... 67

Figure 130. Round 3, Wall 6 sheathing MC in Seattle (Zone 4C), north (left) and south (right) .............. 67

Figure 131. Round 3, Wall 6 sheathing MC in Chicago (Zone 5A), north (left) and south (right) ........... 67

Figure 132. Round 3, Wall 6 sheathing MC in Minneapolis (Zone 6A), north (left) and south (right)...... 68

Unless otherwise noted, all figures were created by Building Science Corporation. 


\section{List of Tables}

Table 1. Round 1 (2x4 Framing, R-13 Fiberglass) Wall Assemblies ...................................................... 7

Table 2. Round 2 (2x6 Framing, R-19 Fiberglass) Wall Assemblies ......................................................... 8

Table 3. Round 3 (2x6 Framing, R-19 Fiberglass, Kraft Facing $\rightarrow$ Polyethylene) Wall Assemblies ............ 9

Table 4. Simulation Geographic Locations with Climate Zones ........................................................... 10

Table 5. Simulation Locations with Climate Zones and Interior RH Levels .......................................... 11

Table 6. Cladding and Stud Bay Ventilation Rates, in Air Changes per Hour ......................................... 12

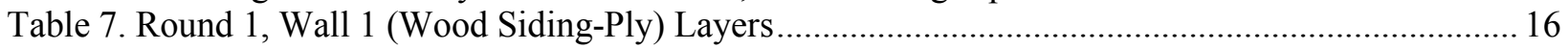

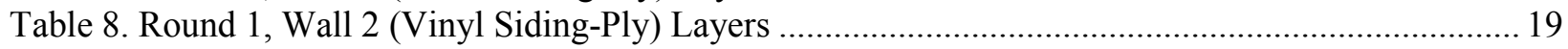

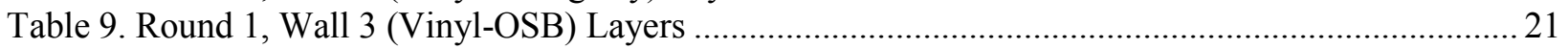

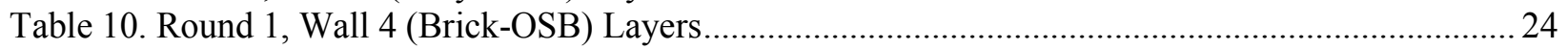

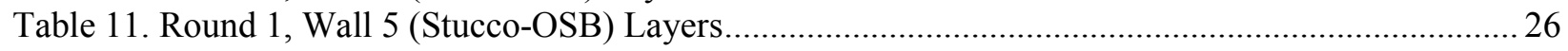

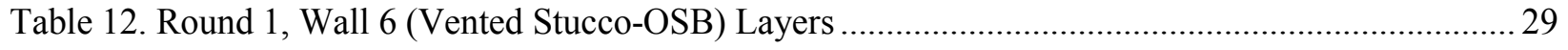

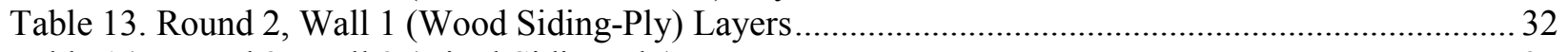

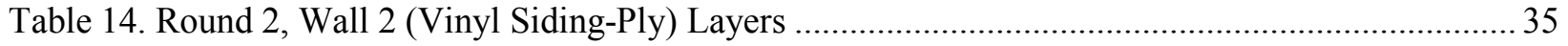

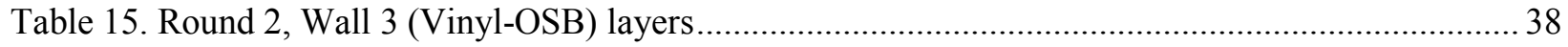

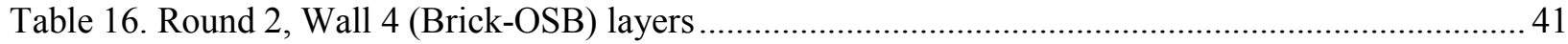

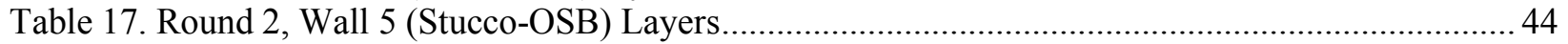

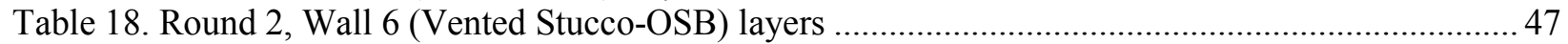

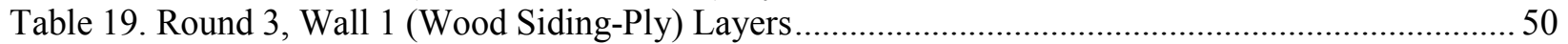

Table 20. Round 3, Wall 2 (Vinyl Siding-Ply) layers.......................................................................... 53

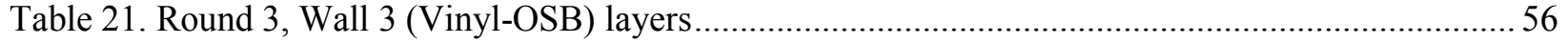

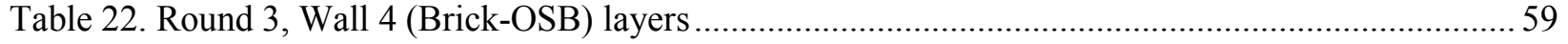

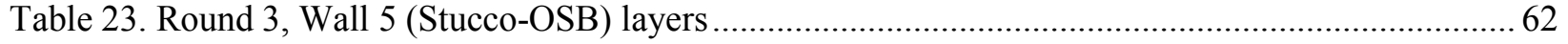

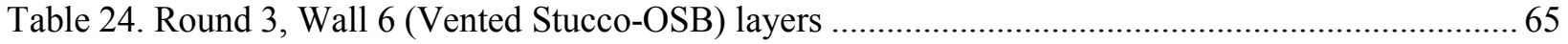

Unless otherwise noted, all tables were created by Building Science Corporation. 


\section{Definitions}

$\mathrm{ACH}$

ASHRAE

DOE

IECC

$\mathrm{MC}$

NREL

OSB

$\mathrm{RH}$

WUFI
Air changes per hour

American Society of Heating, Refrigerating and Air-Conditioning Engineers, Inc.

U.S. Department of Energy

International Energy Conservation Code

Moisture content (wood $\%$ by weight)

National Renewable Energy Laboratory

Oriented strand board

Relative humidity

Wärme und Feuchte instationär (software model) 


\section{Executive Summary}

Using simulations that predict hygrothermal behavior of building enclosure assemblies is increasingly common among researchers, architects, designers, and energy analysts. Such simulations can be powerful tools, but with increasing dissemination of these modeling toolsmost notably the Wärme und Feuchte instationär (WUFI) software model-less-experienced practitioners have run models that provide unrealistic results. In some cases these results contradict extensive field experience and known history of assemblies, which result in confusion in the building industry and problems with advancing the knowledge of moisture-safe building enclosure/shell assemblies.

Building Science Corporation modeled typically well-performing wall assemblies using WUFI Version 5.3 software and demonstrated that these models agree with historic experience when calibrated and modeled correctly. This technical report provides a library of WUFI modeling input data and results. Within the limits of existing experience, this information can be generalized for applications to a broad population of houses.

WUFI was calibrated, or "tuned," using wall assemblies with historically successful performance. The primary performance criterion or failure criterion establishing historic performance was moisture content of the exterior sheathing-more specifically, historic reports of decay based on the observation of large numbers of wall assemblies (buildings) during a decade or longer. The primary tuning parameters (simulation inputs) were specifying airflow and appropriate material properties. "Rational" hygric loads were established based on experiencespecifically, rain wetting and interior moisture (relative humidity) levels. The tuning parameters were limited or bounded by published data or experience.

WUFI is a one-dimensional combined heat and moisture flow model. Typical building assemblies are multilayer systems with complex three-dimensional airflow pathways. Onedimensional combined heat and moisture flow models have proven difficult to use for analysis in these types of assemblies due to the complexity added by the airflow and rain components.

Rain is a significant moisture load, and modeling the rain transport mechanism - a threedimensional phenomenon in a multilayer system - adds more complexity. The WUFI rain modeling inputs assumed a fraction (1\%) of the incident water penetrating passed the cladding and a smaller fraction $(0.01 \%)$ penetrating past the water control layer and into the sheathing.

WUFI is capable of modeling cladding ventilation by introducing interior or exterior air into an air space within the assembly. This allows for explicit (and correct) modeling of ventilated rainscreen behaviors. Using this airflow model within WUFI also allows for the analysis of "through the assembly airflow" (i.e., air leakage through typical imperfect assemblies). The flow was approximated by adding air spaces between the insulation and sheathing, where interior- and exterior-sourced air was introduced.

Running the rainwater and airflow tuned WUFI software model generated the library of input data and results presented. The results agree with historical experience of these assemblies constructed in the climate zones modeled. 
The WUFI templates provided with this report supply useful information and resources to new or less-experienced users. The files present various custom settings that help avoid results that require overly conservative enclosure assemblies. Overall, better material data, consistent initial assumptions, and consistent inputs among practitioners will improve the quality of WUFI modeling and the level of sophistication in the field. 


\section{Introduction}

Hygrothermal simulations such as the Wärme und Feuchte instationär (WUFI) software model (Künzel 2002) are coming into increasingly common use among building science researchers and practitioners, architects and designers, and energy analysts. Such simulations have been shown to be powerful and validated tools that predict hygrothermal behavior of enclosure assemblies. Simulation developers have continued to expand the capabilities of such tools over time.

However, with increasing dissemination of these modeling tools, most notably WUFI, lessexperienced or less-informed practitioners have run models that provide unrealistic resultstypically overly conservative. In some cases, these results clearly contradict extensive field experience and known history of assemblies, showing failure when failure does not occur in reality. In other more worrisome cases, models run on assemblies that clearly have not performed well historically. This has resulted in confusion in the building industry-specifically, problems with advancing knowledge of moisture-safe building enclosure/shell assemblies. Development of moisture-safe enclosure assemblies is a component that will contribute to the Building America target of reducing residential carbon emissions $20 \%$ by 2020 and $80 \%$ by 2050 .

The National Renewable Energy Laboratory (NREL) and the U.S. Department of Energy's (DOE) Building America Standing Technical Committee on Enclosures presented top priorities for research in their document Building America Technical Innovations Leading to 50\% Savings - A Critical Path (NREL 2013). Critical Milestone E4, under Enclosures, states:

"Develop guidance on design methods for enclosure design with a focus on above-grade walls; guidance to be provided for both new construction and retrofits in all U.S. climate zones."

To address this priority, Building Science Corporation modeled typical wall assemblies that have performed well historically, and demonstrated that these models agree with historic experience when calibrated and modeled correctly. A library of input data and results are provided.

\subsection{Background}

Hygrothermal analysis is a relatively new field. The fundamentals date back to the $1950 \mathrm{~s}$. Analysis was observation and experience based. The major focus was rain and groundwater control. As insulation was introduced into assemblies, energy flows were altered, resulting in materials remaining wetter for longer periods of time. Simultaneously, new building materials were introduced that were inherently more water sensitive. The focus shifted from rain and groundwater to vapor movement in the form of air transport and molecular diffusion. Calculation methods of predicting performance and assessing risk were primitive and typically fundamentally flawed. Analysis remained rooted in observation and experience; i.e., a "build it, wet it, watch what happens" methodology.

In the 1980s with the advent of numerical analysis and computer availability, it was believed that a shift from observation and experience to numerical methods based on physics was possible. Numerous models were developed but none with reasonable predictive capability. In the 1990s this changed based on work done in Canada (Kumaran et al. 1994) and Sweden (Viitanen and Ritschkoff 1991). These models were principally research tools rather than design tools. Work done in Germany in 2000 changed the modeling status quo (Künzel 2002). However, such design 
models were limited to mass assemblies typical to Europe. North American assemblies are hollow, multilayered, and dominated by three-dimensional airflow networks that have proven problematic to modeling efforts.

The dominant European model has proven to be attractive to North American practitioners. WUFI is popular despite its inability to provide reasonable predictive outcomes unless used by an experienced sophisticated user who already "knows" the correct outcome. In fact, despite the sophistication of the numerical analysis, available research is still dominated by experiment. We still must "build it, wet it and watch it." Then, the observed outcomes are used to "tune" available models. The field remains phenomenologically based, as there is yet no widely accepted theory of combined heat and moisture flow.

\subsection{Relevance to Building America's Goals}

Given the Building America goals of reducing home energy use by $30 \%$ to $50 \%$ (compared to 2009 energy codes for new homes and pre-retrofit energy use for existing homes), this research is an effort to reduce the first cost of wall assemblies. Many low-cost high-performance wall assemblies are not being used due to inappropriate failure criteria (ASHRAE Standard 160; American Society of Heating, Refrigerating, and Air-Conditioning Engineers [ASHRAE] 2009) linked with inappropriate hygrothermal modeling.

This work also falls under the category of "2.0 Risk Reduction and Minimization," from the document FY 2014 Residential Energy System Research Needs (NREL 2013).

\subsection{Cost-Effectiveness}

The goal of this research is to encourage the use of lower-cost moisture-safe assemblies that are known to work based on field experience and first principles, which are currently being avoided due to inappropriate failure criteria caused by inappropriate hygrothermal modeling.

\subsection{Tradeoffs and Other Benefits}

Higher-cost moisture-safe assemblies will be replaced with lower-cost moisture-safe assemblies. As the modeling becomes more predictive, a reduction in the reliance on field experimentation is likely to occur, reducing the time between innovation and deployment. 


\section{Simulation Background and Approach}

This section describes Building Science Corporation's simulated wall assemblies, including climate locations, model calibration, failure criteria, interior boundary conditions, drainage cavity and stud bay cavity ventilation, bulk water leakage, and initial moisture conditions.

\subsection{Model Calibration, Failure Criteria, and Wall Selection}

Existing literature and engineering judgment based on experience provided the necessary information to calibrate the WUFI software models (ASHRAE 2013; Shi et al. 2004; Straube et al. 2004; Straube and Smegal 2009). Similarly, existing literature and engineering judgment based on experience was used to analyze and report on the failure thresholds and criteria for above-grade walls (Hutcheon and Handegord 1983; Kumaran et al. 1994; Straube and Burnett 2005; Timusk 2005; Viitanen and Ritschkoff 1991).

The calibration of the software models and analysis of the failure thresholds/criteria was accomplished by first understanding above-grade walls with historically successful performance (Künzel 2002; Ojanen et al. 1994). Walls with historically successful performance were identified by the participants of a Building America Expert Meeting (Ueno and Lstiburek 2014) and by Building Science Corporation dialog with the home building industry and code authorities.

A round of WUFI files was generated based on these identified common wall assemblies. The behavior of these assemblies was examined to determine appropriate failure criteria based on this historic record. The intent was to counter much of the common existing modeling, which shows that walls known to perform well (historically) do not meet various failure criteria ( $A S H R A E$ Standard 160, ASHRAE 2009). Each of these wall assemblies is accompanied by a short case study that explains the history of the wall, how it works (hygrothermally), the function of each component (air barrier versus vapor retarder versus water control), and the thought process behind the design.

All simulations were run using WUFI one-dimensional software, version 5.3. Simulations were run for a period of 3 years to reduce the effect of initial conditions (moisture stored in building materials), and to show longer-term trends of moisture accumulation or drying.

\subsection{Simulated Wall Assemblies}

Three rounds of simulation work were conducted (Round 1, Round 2, and Round 3); each successive round of simulations was used to "tune" successive rounds. Wall assembly variables included standard framing $(2 \times 4)$ versus advanced framing $(2 \times 6)$, i.e., R-13 versus R-19 insulation; plywood sheathing versus oriented strand board (OSB) sheathing; vapor retarders (Class II) versus vapor barriers (Class I); and unvented and drained claddings versus vented and drained claddings.

The three simulation rounds changed the "base wall" (cavity insulation level and interior vapor control) as follows:

- Round 1 is based on a 2x4 (R-13 fiberglass batt insulation) wall with interior vapor control provided by an interior Kraft facer on the fiberglass batt insulation. 
- Round 2 substitutes 2x6 framing (R-19 fiberglass batt insulation) for the $2 \times 4$ framing of Round 1.

- $\quad$ Round 3 changes Round 2 by replacing the Kraft facer with 6-mil polyethylene.

Within each round, a series of changes were made to the cladding types and exterior structural sheathing. There were six wall combinations per round as discussed below:

- Wall 1 (Wood Siding-Ply): latex-painted wood siding over plywood sheathing

- Wall 2 (Vinyl Siding-Ply): changes Wall 1 by substituting vinyl siding for wood siding; highlighted in red in Table 1, Table 2, and Table 3

- Wall 3 (Vinyl-OSB): changes Wall 2 by substituting OSB sheathing for plywood; highlighted in green in Table 1, Table 2, and Table 3

- Wall 4 (Brick-OSB): changes Wall 3 by replacing vinyl siding with a drained and ventilated brick cladding; highlighted in blue in Table 1, Table 2, and Table 3

- Wall 5 (Stucco-OSB): changes Wall 4 by replacing brick with hard-coat stucco, applied over two layers of \#15 felt; highlighted in blue in Table 1, Table 2, and Table 3

- Wall 6 (Vented Stucco-OSB): changes Wall 5 by replacing stucco with stucco applied over a spacer or "breather" mesh between two layers of \#15 felt; highlighted in blue in Table 1, Table 2, and Table 3. The reasoning behind this spacer mesh in promoting ventilation drying is discussed by Lstiburek (2007).

All walls use \#15 asphalt saturated Kraft paper (building paper) as a water control layer/drainage plane, fiberglass stud bay insulation, and interior gypsum board with latex paint.

All simulations were performed in six climate zones (see 2.3 Climate Locations), resulting in 36 simulations ( 6 walls multiplied by 6 climates) per round.

The full listing of the wall assembly components are shown in Table 1 (Round 1), Table 2 (Round 2) and Table 3 (Round 3). 
Table 1. Round 1 (2x4 Framing, R-13 Fiberglass) Wall Assemblies

\begin{tabular}{|c|c|c|c|c|c|c|}
\hline & $\begin{array}{l}\text { Wall } 1 \text { (Wood } \\
\text { Siding-Ply) }\end{array}$ & $\begin{array}{l}\text { Wall } 2 \text { (Vinyl } \\
\text { Siding-Ply) }\end{array}$ & $\begin{array}{l}\text { Wall } 3 \\
\text { (Vinyl-OSB) }\end{array}$ & $\begin{array}{l}\text { Wall } 4 \\
\text { (Brick-OSB) }\end{array}$ & $\begin{array}{l}\text { Wall } 5 \\
\text { (Stucco-OSB) }\end{array}$ & $\begin{array}{l}\text { Wall } 6 \text { (Vented } \\
\text { Stucco-OSB) }\end{array}$ \\
\hline Cladding & $\begin{array}{l}\text { latex-painted wood } \\
\text { siding }\end{array}$ & vinyl siding & vinyl siding & brick veneer & stucco & $\begin{array}{l}\text { stucco } \\
\# 15 \text { asphalt paper } \\
\text { polypropylene } \\
\text { drainage mat } \\
(1 / 2 \text { in.) }\end{array}$ \\
\hline $\begin{array}{l}\text { Water Control } \\
\text { Layer }\end{array}$ & \#15 asphalt paper & \#15 asphalt paper & \#15 asphalt paper & \#15 asphalt paper & $\begin{array}{l}\# 15 \text { asphalt paper } \\
\text { (2 layers) }\end{array}$ & \#15 asphalt paper \\
\hline $\begin{array}{l}\text { Structural } \\
\text { Sheathing }\end{array}$ & plywood sheathing & plywood sheathing & OSB sheathing & OSB sheathing & OSB sheathing & OSB sheathing \\
\hline Framing & $2 \times 4$ framing & $2 \times 4$ framing & $2 \times 4$ framing & $2 \times 4$ framing & $2 \times 4$ framing & $2 \times 4$ framing \\
\hline $\begin{array}{l}\text { Cavity } \\
\text { Insulation }\end{array}$ & $\begin{array}{l}\text { R-13 fiberglass } \\
\text { batt }\end{array}$ & $\begin{array}{l}\text { R-13 fiberglass } \\
\text { batt }\end{array}$ & $\begin{array}{l}\text { R-13 fiberglass } \\
\text { batt }\end{array}$ & $\begin{array}{l}\mathrm{R}-13 \text { fiberglass } \\
\text { batt }\end{array}$ & $\begin{array}{l}\text { R-13 fiberglass } \\
\text { batt }\end{array}$ & $\begin{array}{l}\text { R-13 fiberglass } \\
\text { batt }\end{array}$ \\
\hline Vapor Control & $\begin{array}{l}\text { Kraft facer on } \\
\text { fiberglass batt }\end{array}$ & $\begin{array}{l}\text { Kraft facer on } \\
\text { fiberglass batt }\end{array}$ & $\begin{array}{l}\text { Kraft facer on } \\
\text { fiberglass batt }\end{array}$ & $\begin{array}{l}\text { Kraft facer on } \\
\text { fiberglass batt }\end{array}$ & $\begin{array}{l}\text { Kraft facer on } \\
\text { fiberglass batt }\end{array}$ & $\begin{array}{l}\text { Kraft facer on } \\
\text { fiberglass batt }\end{array}$ \\
\hline Interior Finish & gypsum wall board & gypsum wall board & gypsum wall board & gypsum wall board & gypsum wall board & gypsum wall board \\
\hline Interior Finish & latex paint & latex paint & latex paint & latex paint & latex paint & latex paint \\
\hline
\end{tabular}


Table 2. Round 2 (2×6 Framing, R-19 Fiberglass) Wall Assemblies

\begin{tabular}{|c|c|c|c|c|c|c|}
\hline & $\begin{array}{l}\text { Wall } 1 \text { (Wood } \\
\text { Siding-Ply) }\end{array}$ & $\begin{array}{l}\text { Wall } 2 \text { (Vinyl } \\
\text { Siding-Ply) }\end{array}$ & $\begin{array}{l}\text { Wall } 3 \\
\text { (Vinyl-OSB) }\end{array}$ & $\begin{array}{l}\text { Wall } 4 \\
\text { (Brick-OSB) }\end{array}$ & $\begin{array}{l}\text { Wall } 5 \\
\text { (Stucco-OSB) }\end{array}$ & $\begin{array}{l}\text { Wall } 6 \text { (Vented } \\
\text { Stucco-OSB) }\end{array}$ \\
\hline Cladding & $\begin{array}{l}\text { latex-painted wood } \\
\text { siding }\end{array}$ & vinyl siding & vinyl siding & brick veneer & stucco & $\begin{array}{l}\text { stucco } \\
\# 15 \text { asphalt paper } \\
\text { polypropylene } \\
\text { drainage mat } \\
(1 / 2 \text { in.) }\end{array}$ \\
\hline $\begin{array}{l}\text { Water Control } \\
\text { Layer }\end{array}$ & \#15 asphalt paper & \#15 asphalt paper & \#15 asphalt paper & \#15 asphalt paper & $\begin{array}{l}\# 15 \text { asphalt paper } \\
\text { (2 layers) }\end{array}$ & \#15 asphalt paper \\
\hline $\begin{array}{l}\text { Structural } \\
\text { Sheathing }\end{array}$ & plywood sheathing & plywood sheathing & OSB sheathing & OSB sheathing & OSB sheathing & OSB sheathing \\
\hline Framing & $2 \times 6$ framing & $2 \times 6$ framing & $2 \times 6$ framing & $2 \times 6$ framing & $2 \times 6$ framing & $2 \times 6$ framing \\
\hline $\begin{array}{l}\text { Cavity } \\
\text { Insulation }\end{array}$ & $\begin{array}{l}\text { R-19 fiberglass } \\
\text { batt }\end{array}$ & $\begin{array}{l}\text { R-19 fiberglass } \\
\text { batt }\end{array}$ & $\begin{array}{l}\text { R-19 fiberglass } \\
\text { batt }\end{array}$ & $\begin{array}{l}\text { R-19 fiberglass } \\
\text { batt }\end{array}$ & $\begin{array}{l}\text { R-19 fiberglass } \\
\text { batt }\end{array}$ & $\begin{array}{l}\text { R-19 fiberglass } \\
\text { batt }\end{array}$ \\
\hline Vapor Control & $\begin{array}{l}\text { Kraft facer on } \\
\text { fiberglass batt }\end{array}$ & $\begin{array}{l}\text { Kraft facer on } \\
\text { fiberglass batt }\end{array}$ & $\begin{array}{l}\text { Kraft facer on } \\
\text { fiberglass batt }\end{array}$ & $\begin{array}{l}\text { Kraft facer on } \\
\text { fiberglass batt }\end{array}$ & $\begin{array}{l}\text { Kraft facer on } \\
\text { fiberglass batt }\end{array}$ & $\begin{array}{l}\text { Kraft facer on } \\
\text { fiberglass batt }\end{array}$ \\
\hline Interior Finish & gypsum wall board & gypsum wall board & gypsum wall board & gypsum wall board & gypsum wall board & gypsum wall board \\
\hline Interior Finish & latex paint & latex paint & latex paint & latex paint & latex paint & latex paint \\
\hline
\end{tabular}


Table 3. Round 3 (2x6 Framing, R-19 Fiberglass, Kraft Facing $\rightarrow$ Polyethylene) Wall Assemblies

\begin{tabular}{|c|c|c|c|c|c|c|}
\hline & $\begin{array}{l}\text { Wall } 1 \text { (Wood } \\
\text { Siding-Ply) }\end{array}$ & $\begin{array}{l}\text { Wall } 2 \text { (Vinyl } \\
\text { Siding-Ply) }\end{array}$ & $\begin{array}{l}\text { Wall } 3 \\
\text { (Vinyl-OSB) }\end{array}$ & $\begin{array}{l}\text { Wall } 4 \\
\text { (Brick-OSB) }\end{array}$ & $\begin{array}{l}\text { Wall } 5 \\
\text { (Stucco-OSB) }\end{array}$ & $\begin{array}{l}\text { Wall } 6 \text { (Vented } \\
\text { Stucco-OSB) }\end{array}$ \\
\hline Cladding & $\begin{array}{l}\text { latex-painted wood } \\
\text { siding }\end{array}$ & vinyl siding & vinyl siding & brick veneer & stucco & $\begin{array}{l}\text { stucco } \\
\# 15 \text { asphalt paper } \\
\text { polypropylene } \\
\text { drainage mat } \\
(1 / 2 \text { in.) }\end{array}$ \\
\hline $\begin{array}{l}\text { Water Control } \\
\text { Layer }\end{array}$ & \#15 asphalt paper & \#15 asphalt paper & \#15 asphalt paper & \#15 asphalt paper & $\begin{array}{l}\# 15 \text { asphalt paper } \\
\text { (2 layers) }\end{array}$ & \#15 asphalt paper \\
\hline $\begin{array}{l}\text { Structural } \\
\text { Sheathing }\end{array}$ & plywood sheathing & plywood sheathing & OSB sheathing & OSB sheathing & OSB sheathing & OSB sheathing \\
\hline Framing & $2 \times 6$ framing & $2 \times 6$ framing & $2 \times 6$ framing & $2 \times 6$ framing & $2 \times 6$ framing & $2 \times 6$ framing \\
\hline $\begin{array}{l}\text { Cavity } \\
\text { Insulation }\end{array}$ & $\begin{array}{l}\mathrm{R}-19 \text { fiberglass } \\
\text { batt }\end{array}$ & $\begin{array}{l}\text { R-19 fiberglass } \\
\text { batt }\end{array}$ & $\begin{array}{l}\mathrm{R}-19 \text { fiberglass } \\
\text { batt }\end{array}$ & $\begin{array}{l}\text { R-19 fiberglass } \\
\text { batt }\end{array}$ & $\begin{array}{l}\text { R-19 fiberglass } \\
\text { batt }\end{array}$ & $\begin{array}{l}\mathrm{R}-19 \text { fiberglass } \\
\text { batt }\end{array}$ \\
\hline Vapor Control & polyethylene & polyethylene & polyethylene & polyethylene & polyethylene & polyethylene \\
\hline Interior Finish & gypsum wall board & gypsum wall board & gypsum wall board & gypsum wall board & gypsum wall board & gypsum wall board \\
\hline Interior Finish & latex paint & latex paint & latex paint & latex paint & latex paint & latex paint \\
\hline
\end{tabular}




\subsection{Climate Locations}

All of the wall assemblies were simulated in the climate locations shown in Table 4 and Figure 1 to understand the climate sensitivity of these assemblies.

WUFI database weather files were used for each climate, selecting the cold year data, which is the worst case for interior-sourced interstitial condensation.

Table 4. Simulation Geographic Locations with Climate Zones

\begin{tabular}{lll}
\hline City, State & IECC Climate Zone & Climate Description \\
\hline Minneapolis, MN & $6 \mathrm{~A}$ & Very Cold \\
\hline Chicago, IL & $5 \mathrm{~A}$ & Cold \\
Kansas City, MO & $4 \mathrm{~A}$ & Mixed-Humid \\
\hline Seattle, WA & $4 \mathrm{C}$ & Marine \\
Atlanta, GA & $3 \mathrm{~A}$ & Mixed-Humid \\
\hline Houston, TX & $2 \mathrm{~A}$ & Hot-Humid \\
\hline
\end{tabular}

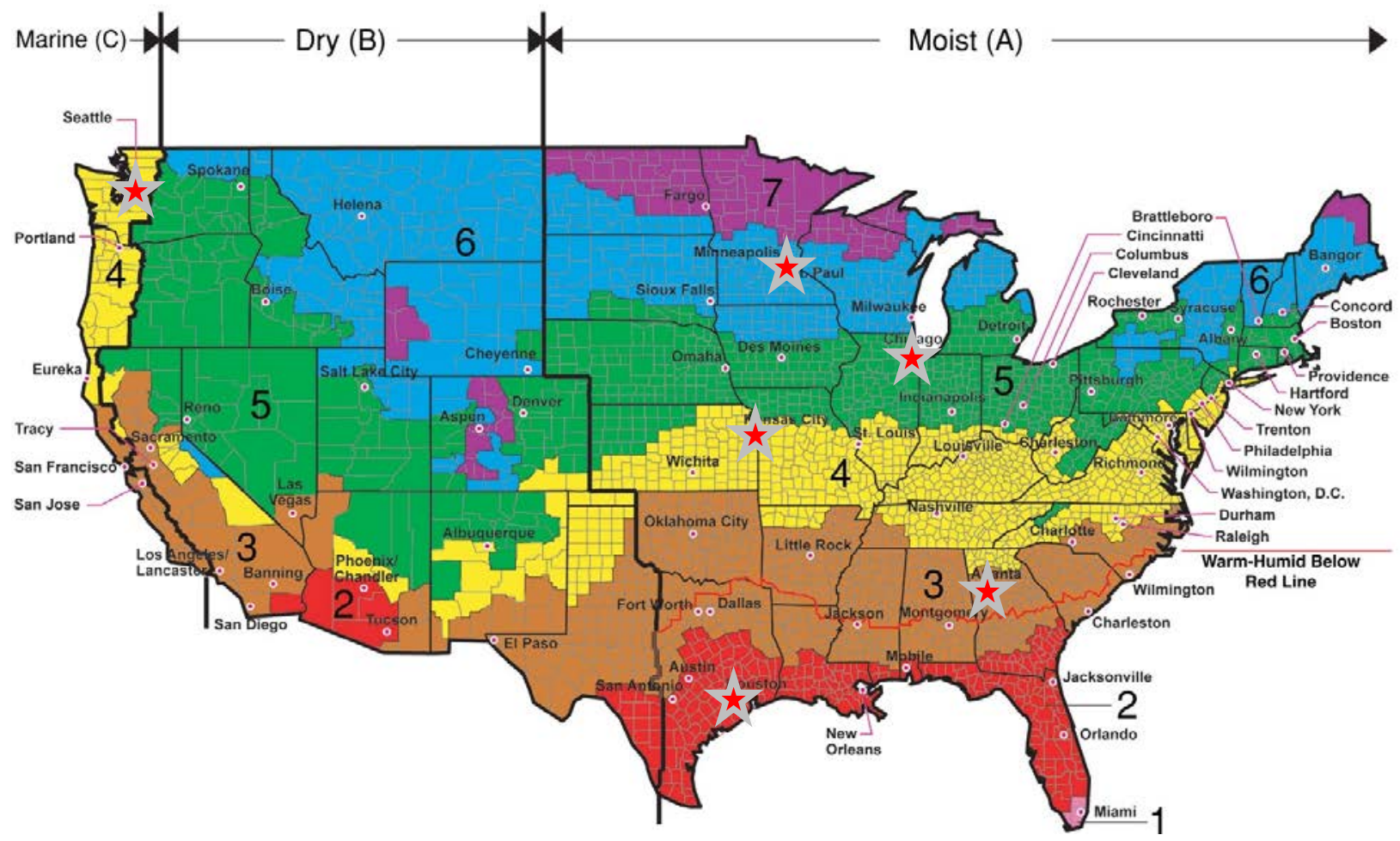

Figure 1. DOE climate zone map with simulated cities highlighted 


\subsection{Interior Boundary Conditions}

Interior conditions have a significant effect on hygrothermal simulations, especially when air leakage from the interior is simulated (see 2.5 Drainage Cavity and Stud Bay Cavity Ventilation). Interior temperature was varied as a sine wave in all climates, set at $75^{\circ} \mathrm{F} \pm 2^{\circ} \mathrm{F}$ $\left(73^{\circ} \mathrm{F}\right.$ to $\left.77^{\circ} \mathrm{F}\right)$, with the peak in early August (Figure 2).

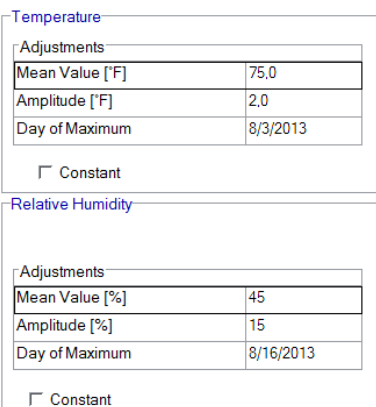

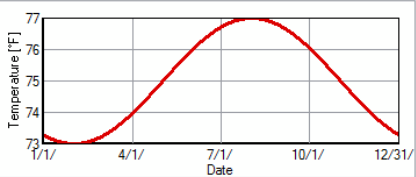

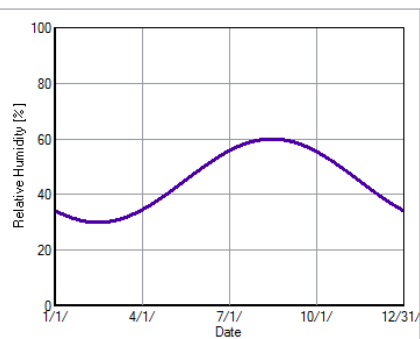

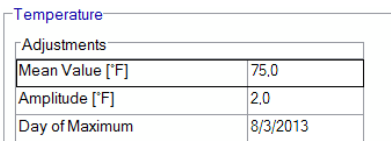

Day of Maximum $8 / 3 / 2013$

$\ulcorner$ Constant

Relative Humidity
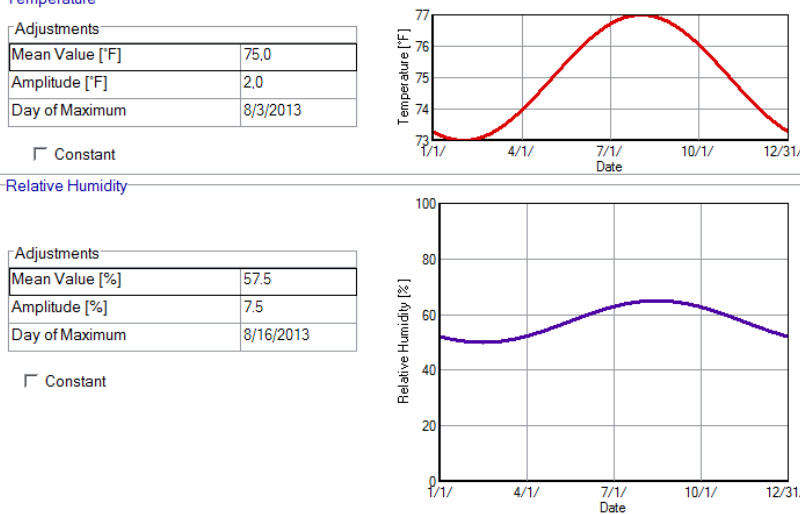

Figure 2. Interior temperature and relative humidity boundary conditions for Chicago (left) and Seattle (right)

Interior relative humidity (RH) levels were also set as a seasonal sine wave (Figure 2). However, interior climate conditions vary by climate region; mixed- and hot-humid climates have higher interior RHs than cold and very cold climates. The resulting sine wave minimum and maximum values are shown in Table 5; the RH maximum is set for mid-August.

Table 5. Simulation Locations with Climate Zones and Interior RH Levels

\begin{tabular}{lcccc}
\hline City, State & Climate Zone & Average RH & Minimum & Maximum \\
\hline Minneapolis, MN & 6A & $45 \%$ & $30 \%$ & $60 \%$ \\
\hline Chicago, IL & 5A & $45 \%$ & $30 \%$ & $60 \%$ \\
Kansas City, MO & 4A & $45 \%$ & $30 \%$ & $60 \%$ \\
\hline Seattle, WA & 4C & $57 \%$ & $50 \%$ & $65 \%$ \\
Atlanta, GA & 3A & $55 \%$ & $40 \%$ & $70 \%$ \\
Houston, TX & 2A & $55 \%$ & $40 \%$ & $70 \%$ \\
\hline
\end{tabular}

\subsection{Drainage Cavity and Stud Bay Cavity Ventilation}

Most of the claddings are designed as drained and ventilated cavities, which allow outside airflow behind the cladding to provide drying of rain wetting of the cladding. This ventilation airflow also bypasses vapor-impermeable materials (such as vinyl siding), thus allowing outward drying of the backup wall. 
This ventilation is represented in the WUFI simulation by using an air space (leftmost "air layer" in Figure 3) and providing air change with exterior air in this air space. Ventilation rates were selected based on Straube and Burnett (2005), and are presented in Table 6 ("cladding ventilation") as air changes per hour ( $\mathrm{ACH}$, in units of $1 / \mathrm{h})$. Note that vinyl siding is very air leaky, resulting in the high (200) air change; ventilated brick cavities have a much lower (10) rate. The conventional stucco wall (no ventilation) has no cladding ventilation (which contributes to moisture issues associated with this cladding, per Lstiburek 2007). The vented stucco was modeled at $10 \mathrm{ACH}$.

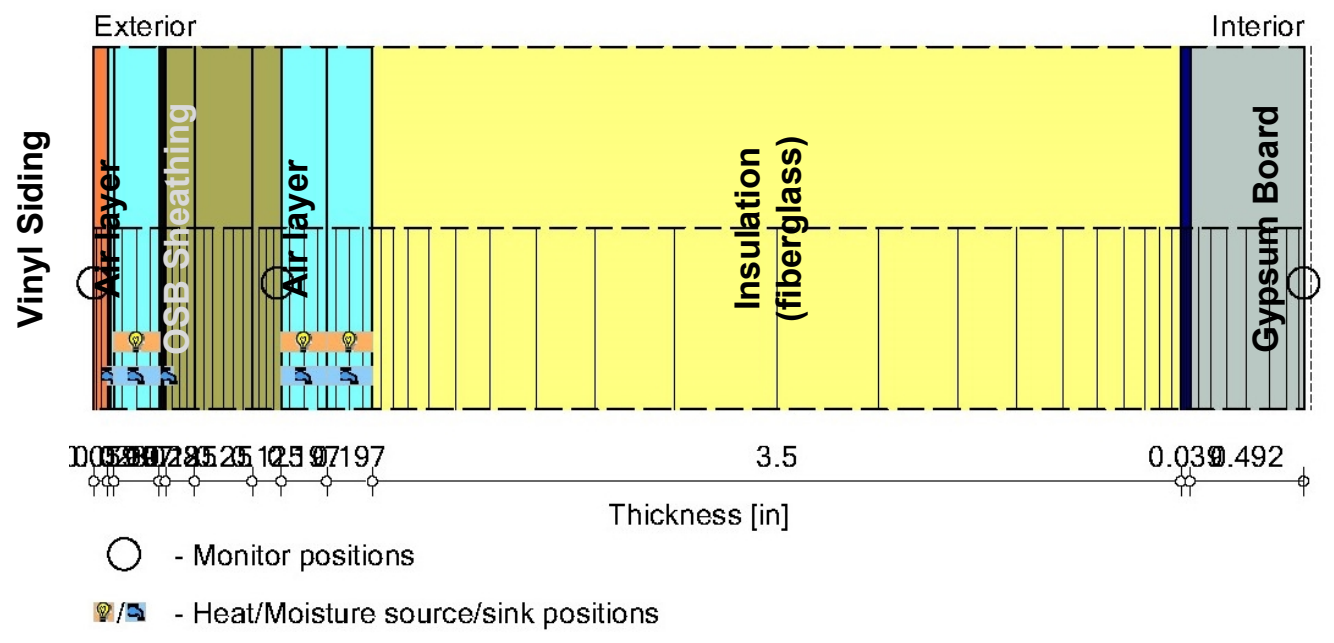

Figure 3. WUFI cross section (Round 1, Wall 3) showing ventilation air spaces

In addition, stud wall cavities are seldom built in a completely airtight manner. This leakage connects the stud bay cavity with both exterior and interior environments. To simulate the effect of this air leakage, small amounts of both exterior air and interior air (10 ACH respectively) were added in a layer inboard of the sheathing as shown in Figure 3 and Table 6.

Table 6. Cladding and Stud Bay Ventilation Rates, in Air Changes per Hour

\begin{tabular}{lrrr}
\hline & $\begin{array}{r}\text { Cladding } \\
\text { Ventilation (1/h) }\end{array}$ & $\begin{array}{r}\text { Sheathing } \\
\text { Ventilation } \\
\text { (Exterior) } \mathbf{( 1 / h )}\end{array}$ & $\begin{array}{r}\text { Sheathing } \\
\text { Ventilation } \\
\text { (Interior) } \mathbf{( 1 / h )}\end{array}$ \\
\hline Wall 1 (Wood Siding-Ply) & 20 & 10 & 10 \\
\hline Wall 2 Vinyl Siding-Ply) & 200 & 10 & 10 \\
Wall 3 (Vinyl-OSB) & 200 & 10 & 10 \\
Wall 4 (Brick-OSB) & 10 & 10 & 10 \\
Wall 5 (Stucco-OSB) & none & 10 & 10 \\
Wall 6 (Vented Stucco-OSB) & 10 & 10 & 10 \\
\hline
\end{tabular}

The ventilation rates are also provided in Appendix D. 


\subsection{Bulk Water Leakage}

In all cases, bulk water was introduced within the assembly to simulate the effect of rainwater exposure and penetration. First, in the exterior-side boundary conditions (Figure 4); 70\% of the incident rain adheres to the vertical wall surface (highlighted in red in Figure 4), and 30\% runs off.

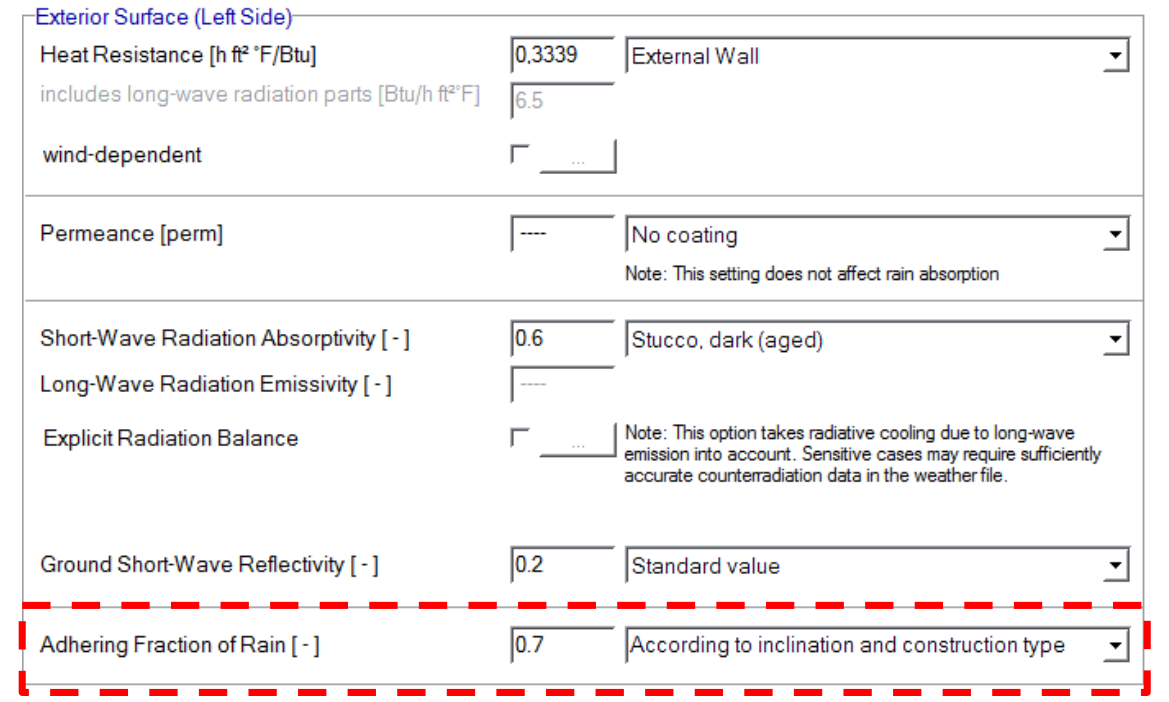

Figure 4. WUFI exterior surface boundary conditions, rain adhesion highlighted

This rainwater was introduced within the assembly using source terms in WUFI and placed as shown in Figure 5. A fraction of the adhering rainfall (1\%) was introduced at the inner face of the exterior surface (cladding) per the green circle in Figure 5. This reflects the fact that all claddings leak some fraction of the incident water. In addition, a smaller fraction $(0.01 \%)$ of the incident rainfall was introduced behind the water control layer (drainage plane) per the orange circle in Figure 5. This is intended to simulate water management failures that commonly occur in construction.

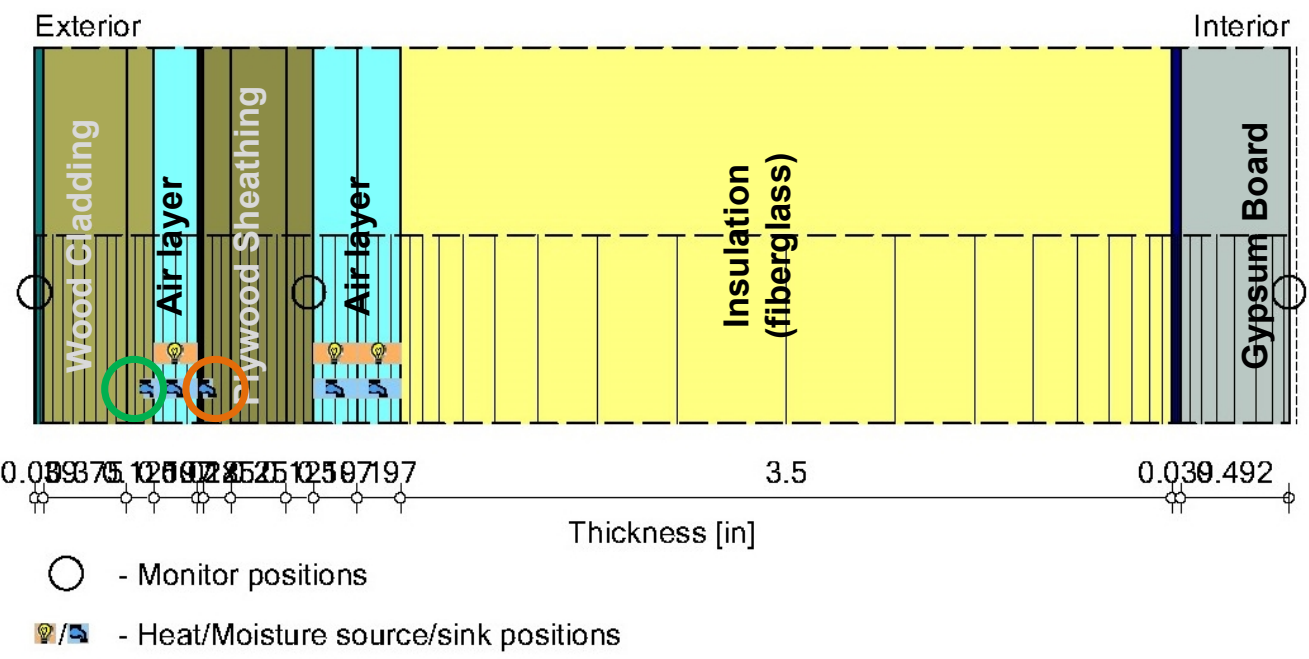

Figure 5. WUFI cross section (Round 1, Wall 1) showing moisture source/sink terms

More specifics on bulk water sources are provided in Appendix D. 


\subsection{Initial Moisture Conditions}

In all cases, wood materials were assumed to meet building-code-required initial moisture content (MC). For example, all wood-based materials used should be below $20 \% \mathrm{MC}$ by weight. 


\section{Wall Simulation Results}

This section presents the detailed descriptions of each of the six wall systems with graphs of sheathing MC, which is a common metric for evaluating failure. A common practice is to plot the $\mathrm{MC}$ of the entire sheathing layer; however, this value is simply the average MC of the sheathing thickness. In reality, sheathing failures are typically associated with high MCs on one face or another - for instance, the interior sheathing face for interior-sourced interstitial condensation, or the exterior face for rain leakage. Therefore, the sheathing was divided into three layers and the MC of the innermost $1 / 8$ in. (0.125 in.), as shown in red in Figure 6, was plotted.

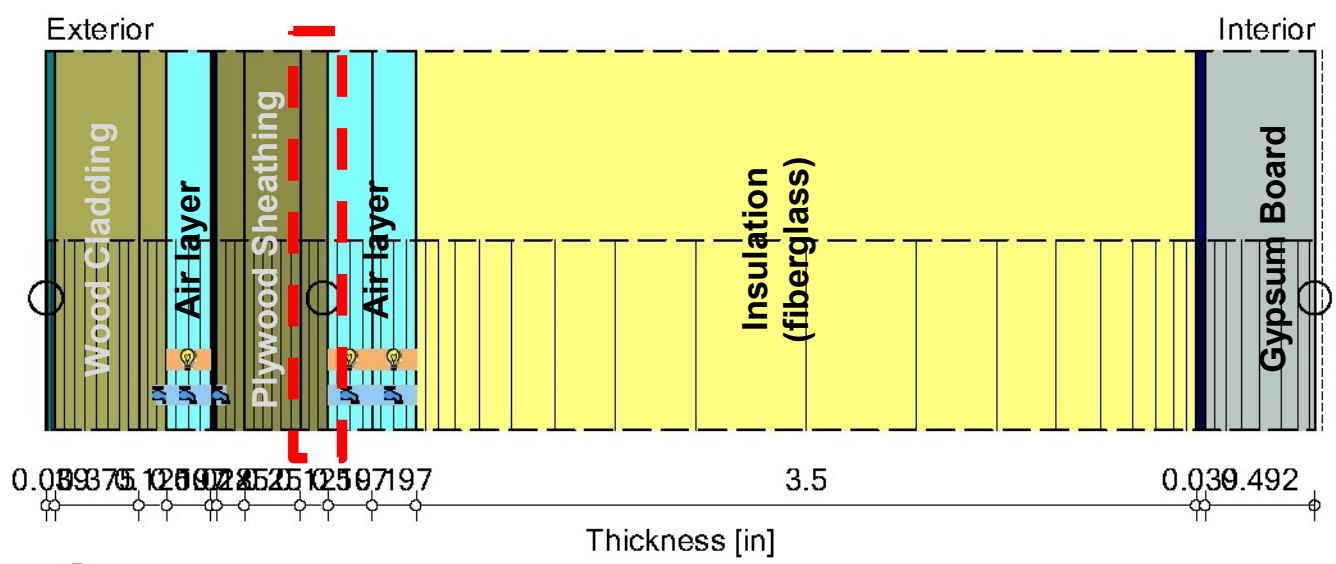

Figure 6. WUFI cross section (Round 1, Wall 1) showing sheathing MC of the interior layer

The original WUFI files will all be available for download for examination and further simulations.

It is important to note that interpreting the results of modeling has been problematic. As noted earlier, wall assemblies that have performed well historically in various climate zones "fail" when standardized moisture failure criteria such as that presented in ASHRAE Standard 160 (2009) are applied. As such, the primary performance criteria or failure criteria establishing historic performance is MC of the exterior sheathing: More specifically, historic reports of decay based on observation of large numbers of wall assemblies ("buildings") over a decade or longer.

\subsection{Round 1 (2x4 Framing, R-13 Fiberglass)}

The first round of wall systems has $2 \times 4$ framing with R-13 fiberglass batt.

\subsubsection{Wall 1 (Wood Siding-Ply)}

Table 7 describes the layers and their respective functions in the Round 1, Wall 1 configuration, and Figure 7 shows the layers from exterior to interior. 
Table 7. Round 1, Wall 1 (Wood Siding-Ply) Layers

\begin{tabular}{ll}
\hline Layer & Function \\
\hline Latex painted wood siding & provides exterior finish for aesthetics \\
\hline Asphalt saturated Kraft paper (building paper) & functions as air and water control layer \\
\hline Plywood sheathing & provides structural support \\
\hline 2x4 framing & provides structural support \\
\hline Kraft-faced R-13 fiberglass batt & functions as thermal and vapor control layer \\
\hline Gypsum wall board & provides interior finish \\
\hline Latex paint & functions as vapor drive throttle \\
\hline
\end{tabular}

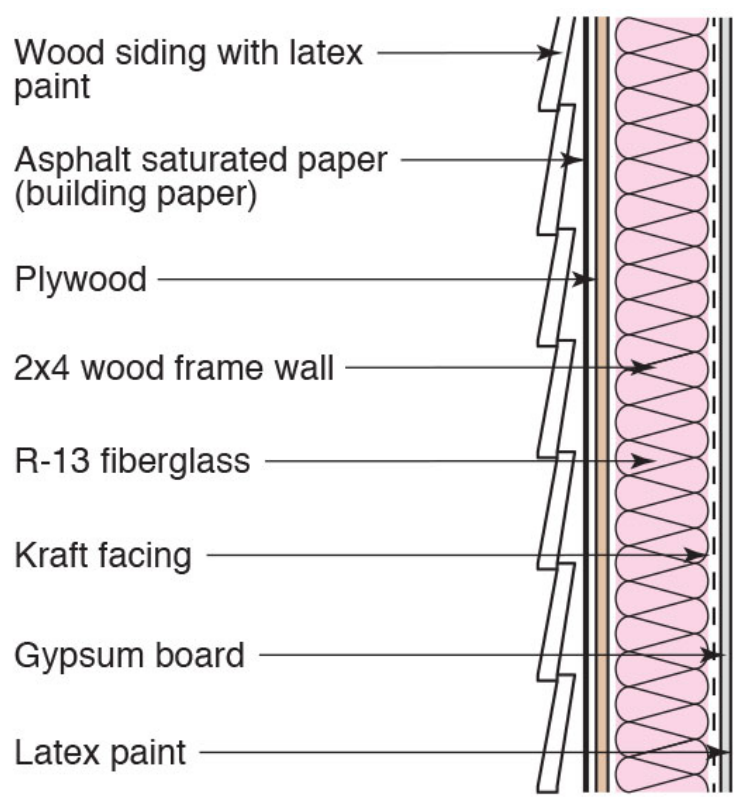

Figure 7. Round 1, Wall 1 (wood siding-ply) configuration

WUFI simulations are run on this wall on both north and south orientations in six climate locations; Figure 8 to Figure 13 show the MC graphs of the interior side of the exterior wall sheathing over a period of 3 years. 

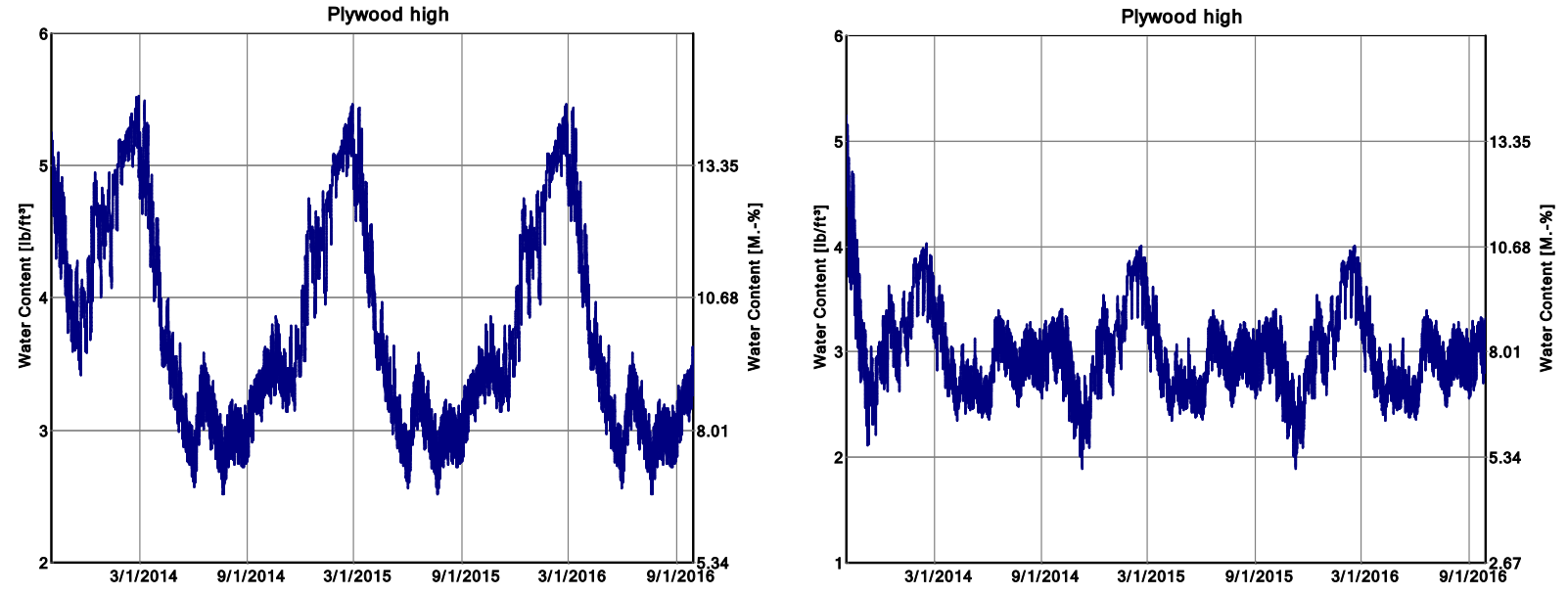

Figure 8. Round 1, Wall 1 sheathing MC in Houston (Zone 2A), north (left) and south (right)
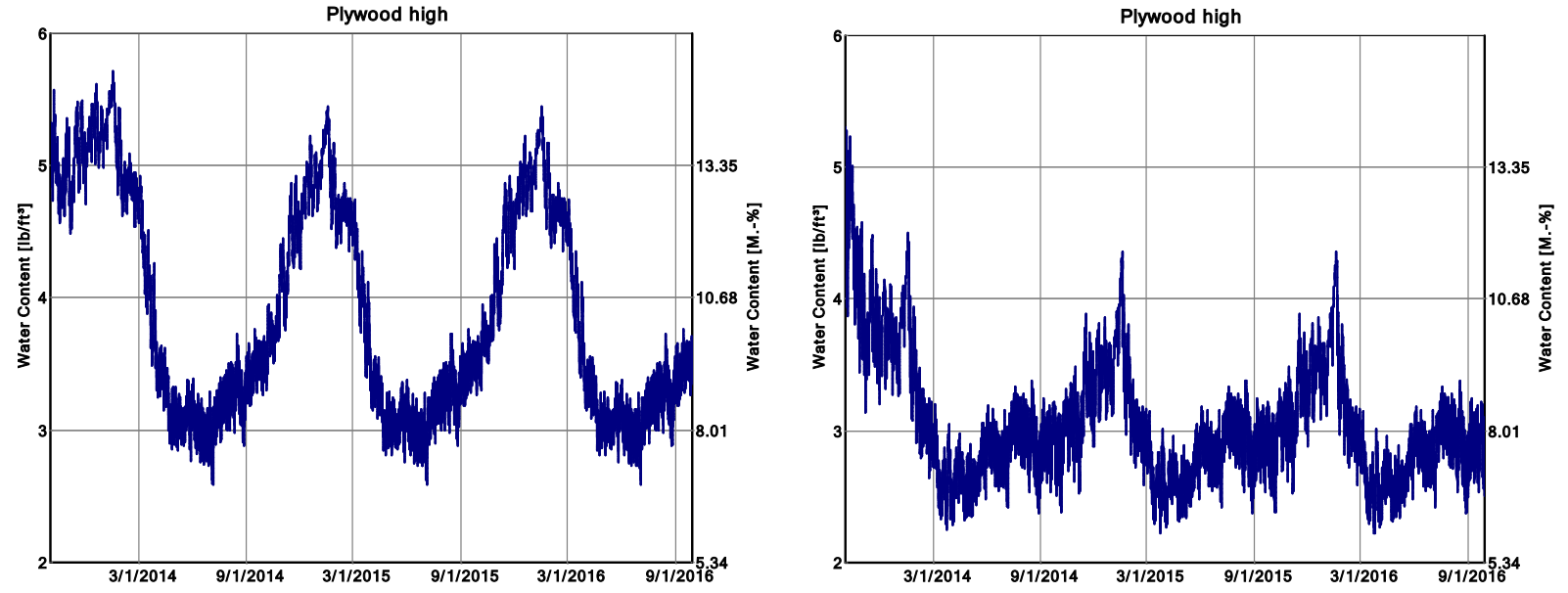

Figure 9. Round 1, Wall 1 sheathing MC in Atlanta (Zone 3A), north (left) and south (right)
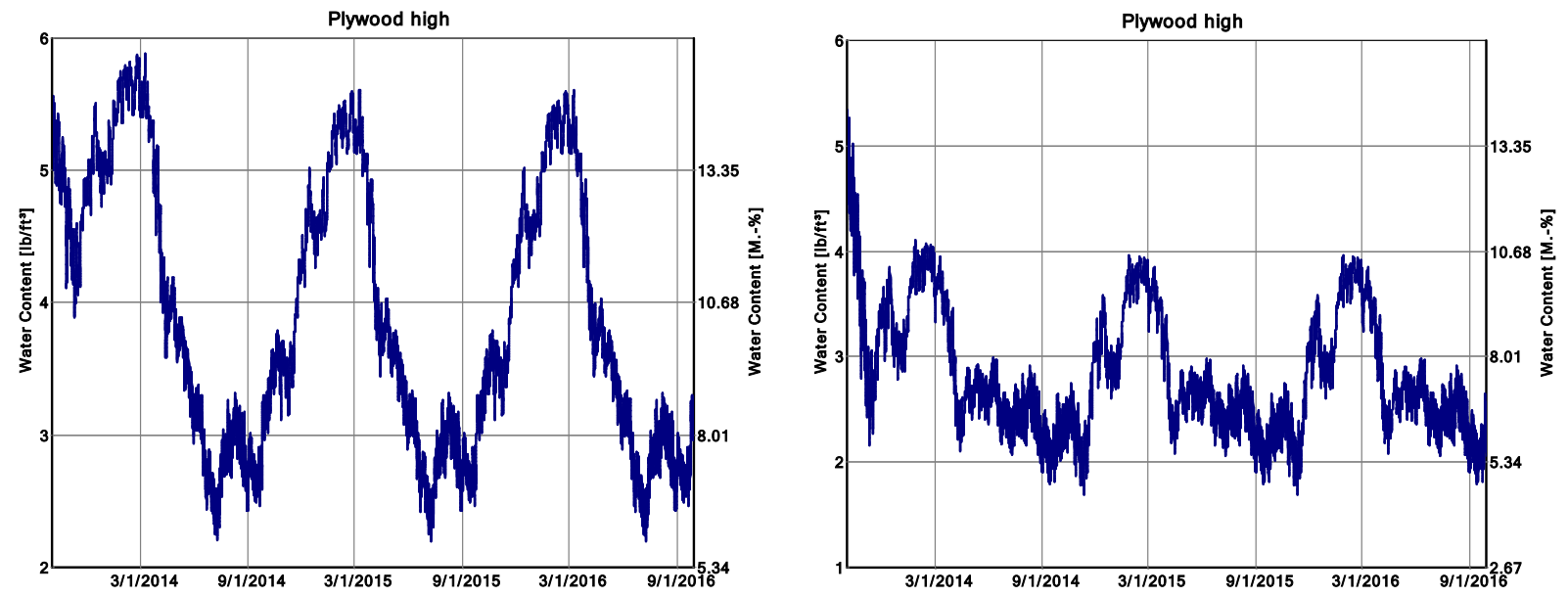

Figure 10. Round 1, Wall 1 sheathing MC in Kansas City (Zone 4A), north (left) and south (right) 

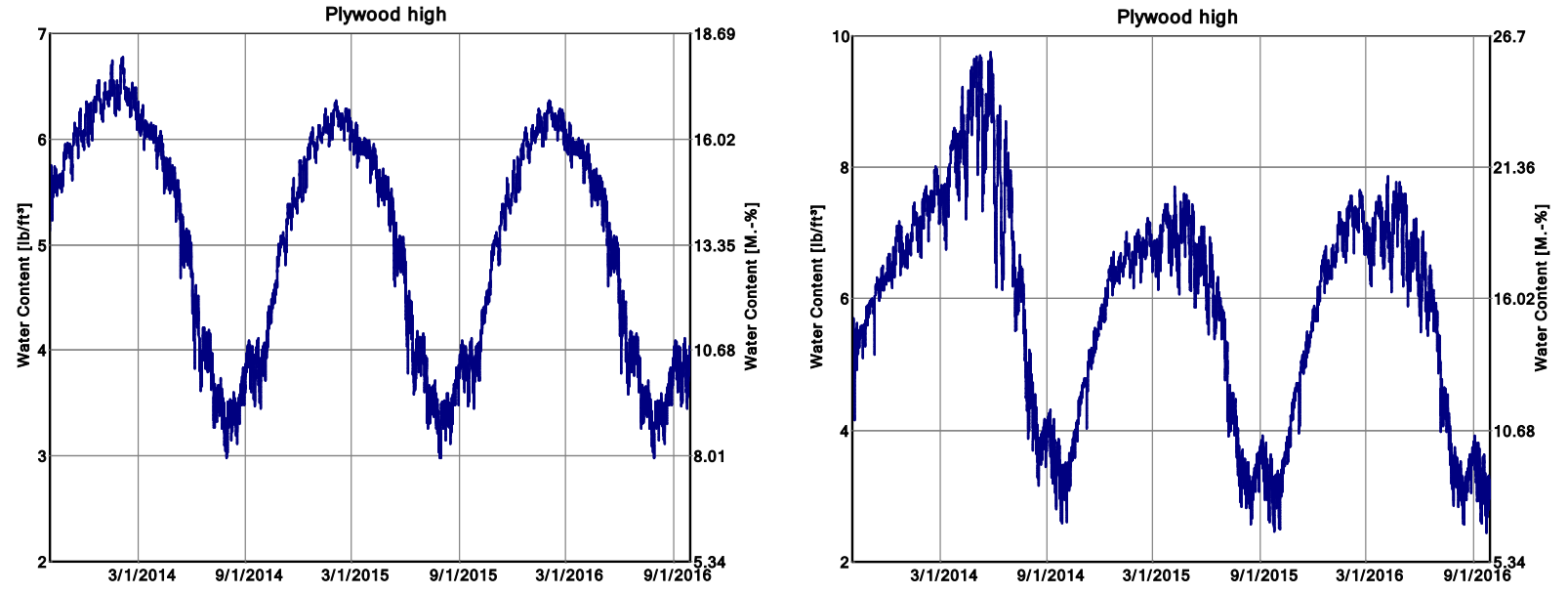

Figure 11. Round 1, Wall 1 sheathing MC in Seattle (Zone 4C), north (left) and south (right)
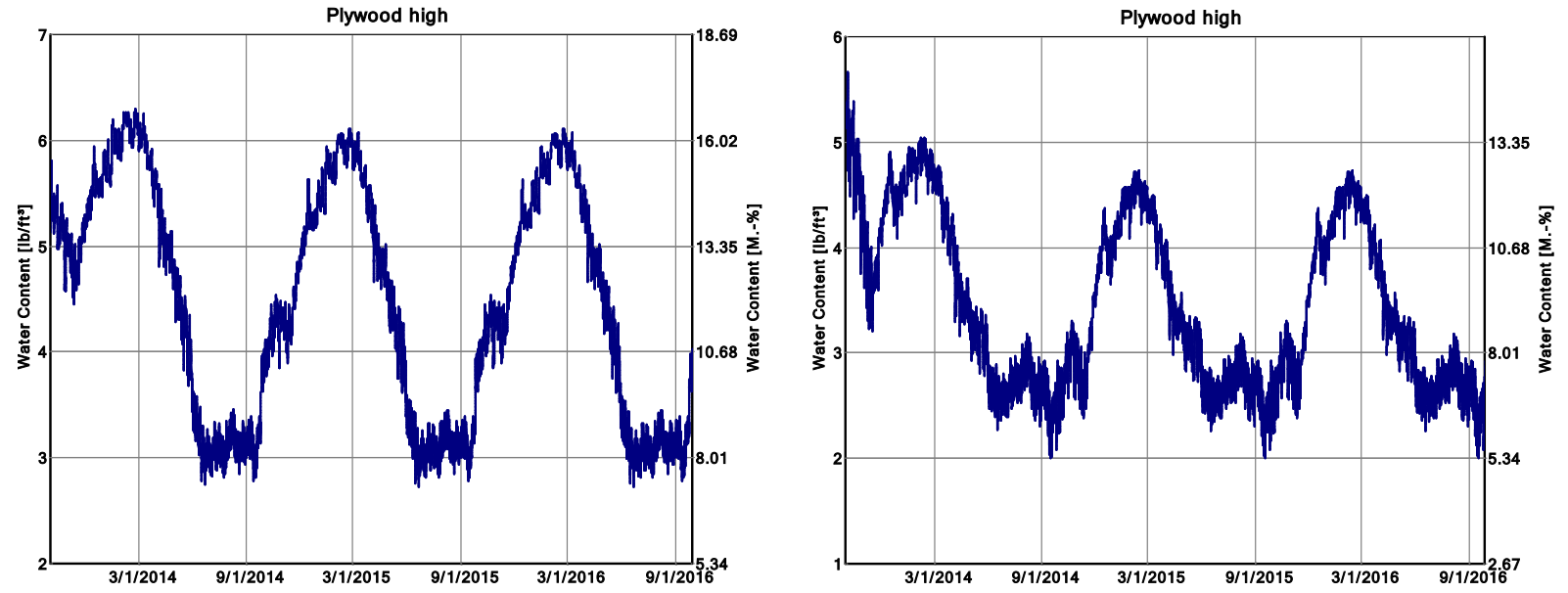

Figure 12. Round 1, Wall 1 sheathing MC in Chicago (Zone 5A), north (left) and south (right)
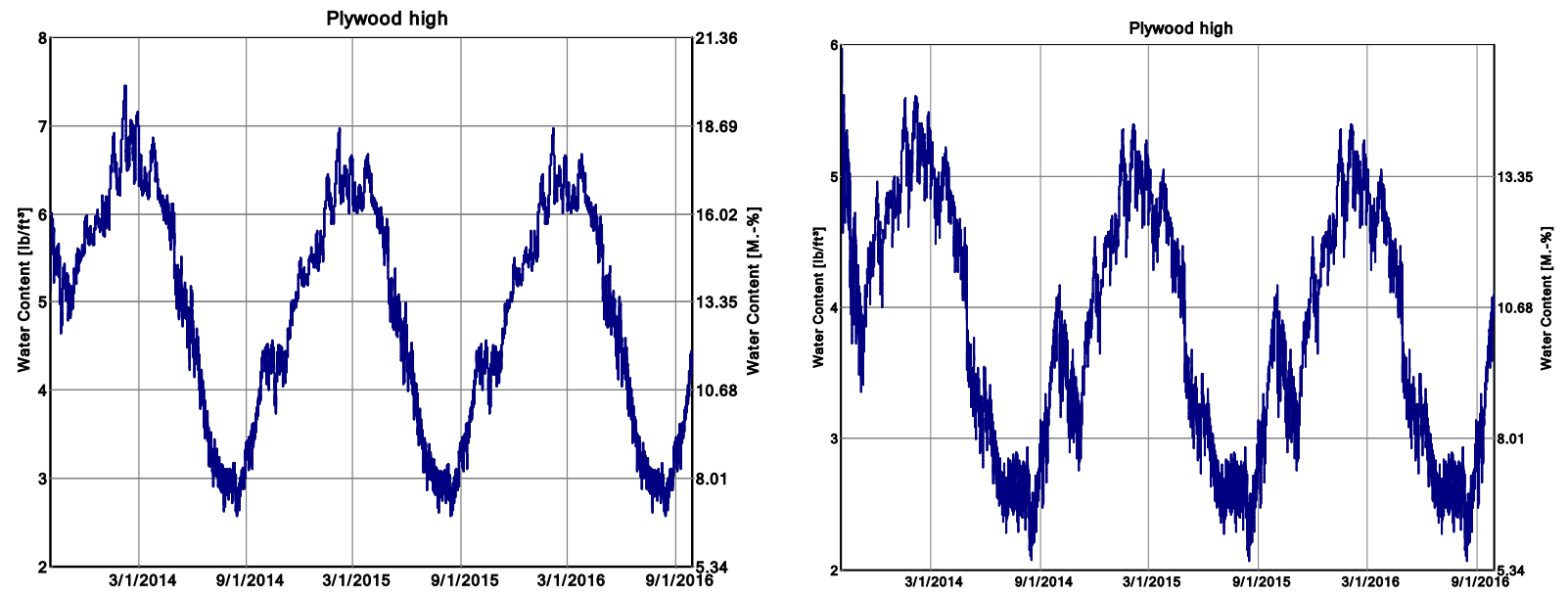

Figure 13. Round 1, Wall 1 sheathing MC in Minneapolis (Zone 6A), north (left) and south (right) 


\subsubsection{Wall 2 (Vinyl Siding-Ply)}

Table 8 describes the layers and their respective functions in the Round 1, Wall 2 configuration, and Figure 14 shows the layers from exterior to interior.

Table 8. Round 1, Wall 2 (Vinyl Siding-Ply) Layers

\begin{tabular}{ll}
\hline Layer & Function \\
\hline Vinyl siding & provides exterior finish for aesthetics \\
\hline Asphalt saturated Kraft paper (building paper) & functions as air and water control layer \\
\hline Plywood sheathing & provides structural support \\
\hline $\mathbf{2 x 4}$ framing & provides structural support \\
\hline Kraft-faced R-13 fiberglass batt & functions as thermal and vapor control layer \\
\hline Gypsum wall board & provides interior finish \\
\hline Latex paint & functions as vapor drive throttle \\
\hline
\end{tabular}

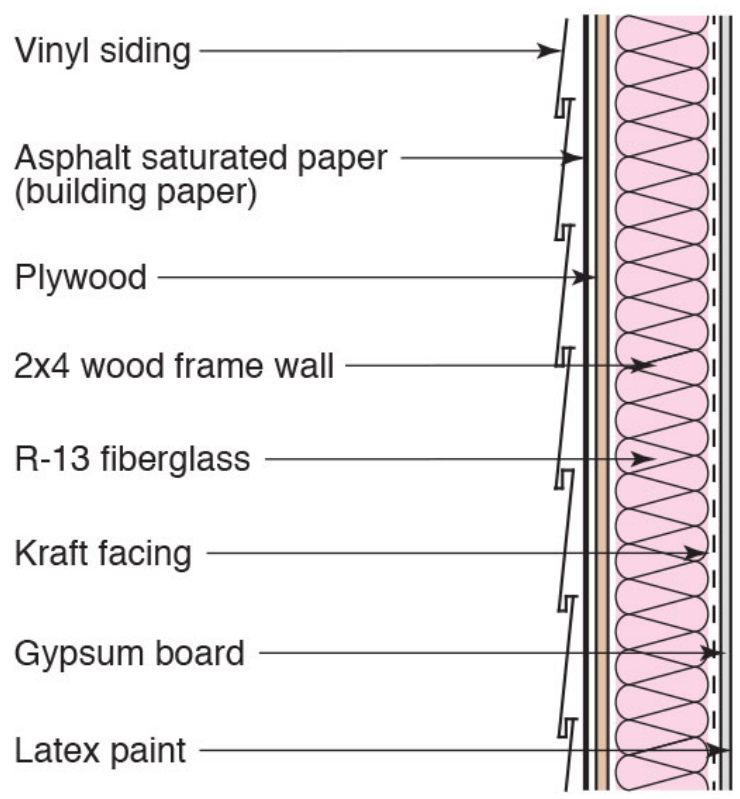

Figure 14. Round 1, Wall 2 (vinyl siding-ply) configuration

WUFI simulations are run on this wall on both north and south orientations in six climate zones; Figure 15 to Figure 20 show the MC graphs of the inner face of wall sheathing over a period of 3 years. 

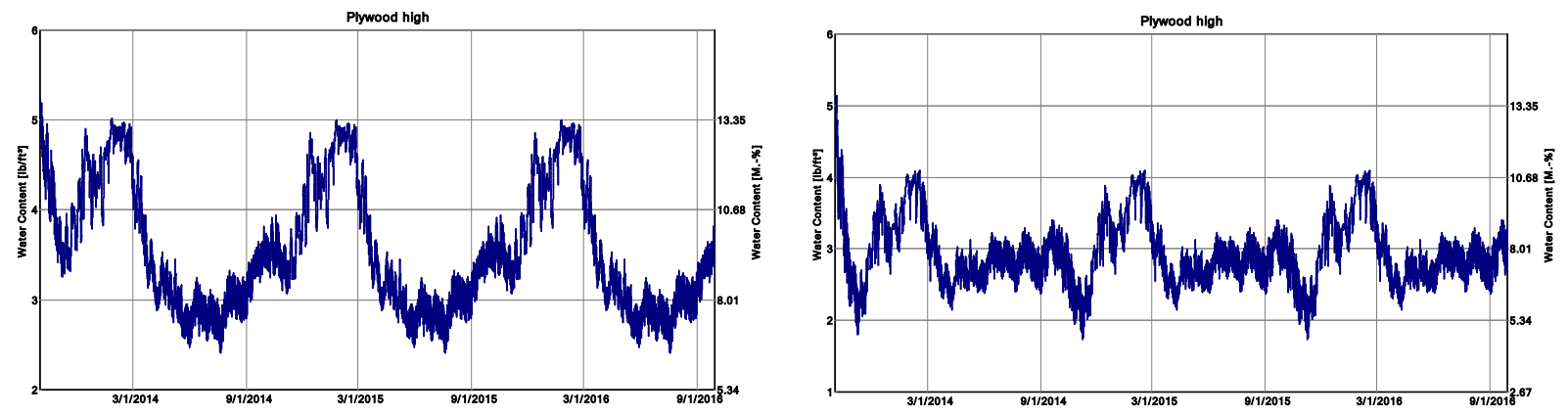

Figure 15. Round 1, Wall 2 sheathing MC in Houston (Zone 2A), north (left) and south (right)
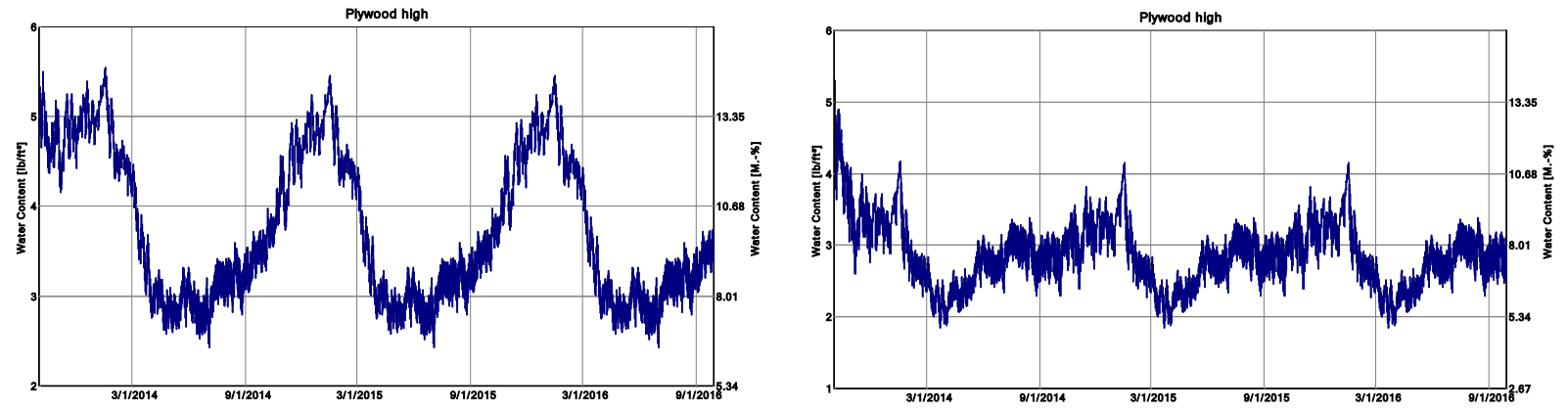

Figure 16. Round 1, Wall 2 sheathing MC in Atlanta (Zone 3A), north (left) and south (right)
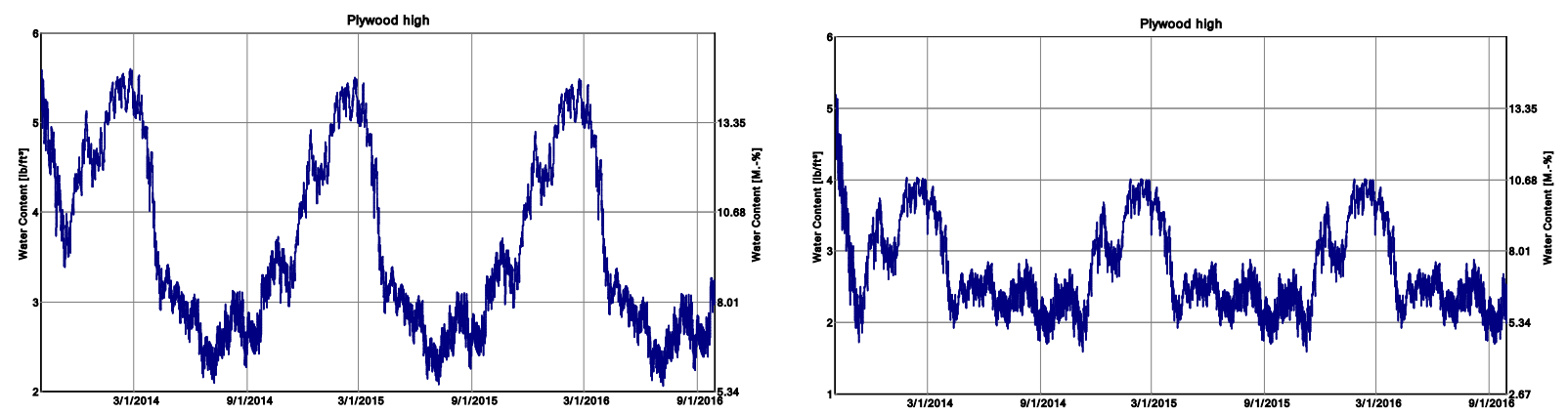

Figure 17. Round 1, Wall 2 sheathing MC in Kansas City (Zone 4A), north (left) and south (right)
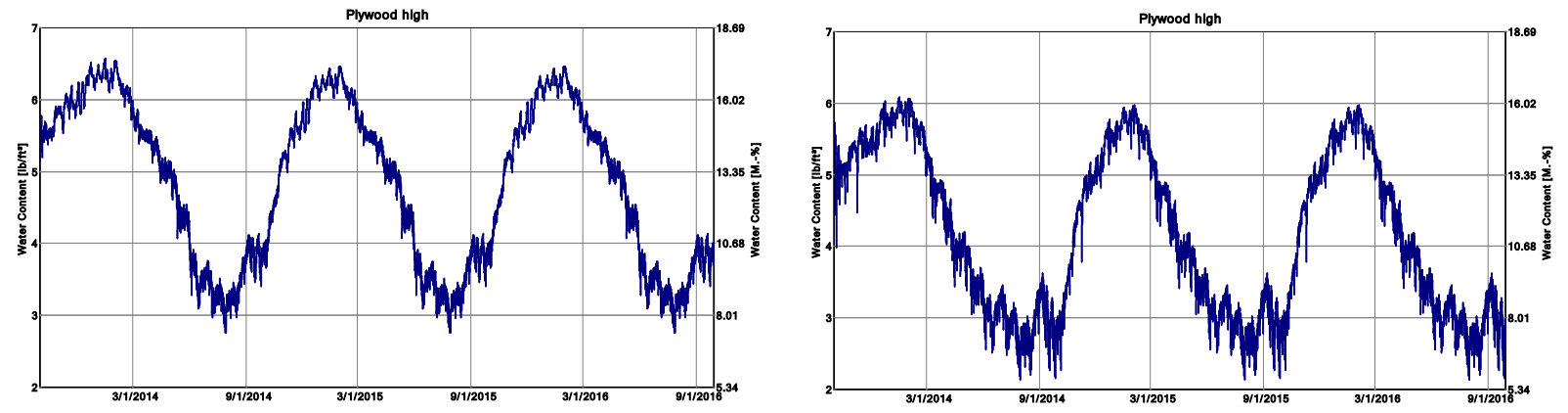

Figure 18. Round 1, Wall 2 sheathing MC in Seattle (Zone 4C), north (left) and south (right) 

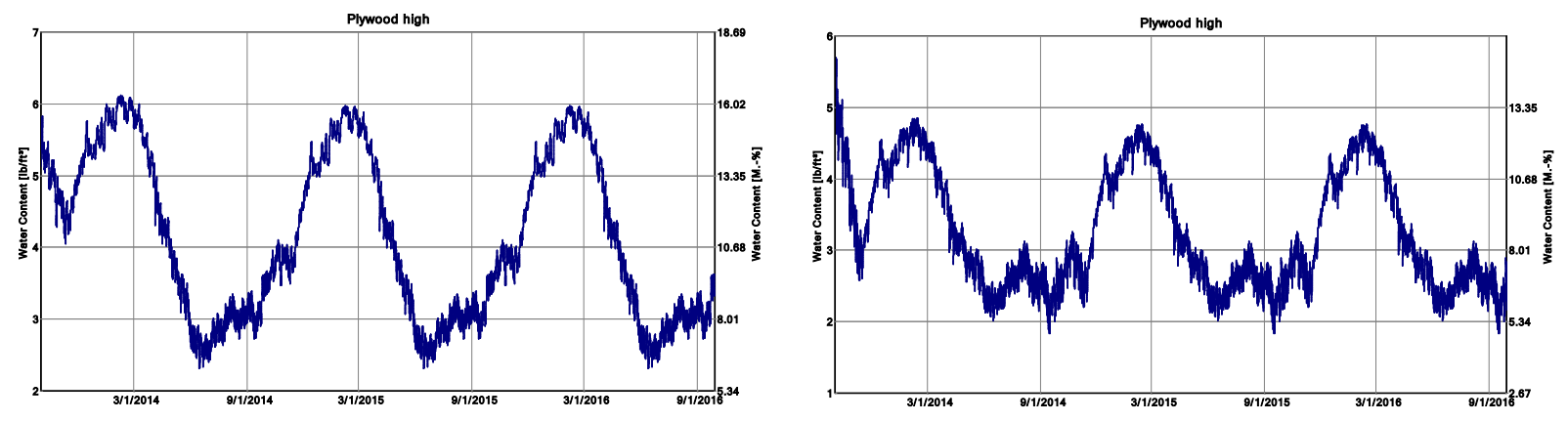

Figure 19. Round 1, Wall 2 sheathing MC in Chicago (Zone 5A), north (left) and south (right)
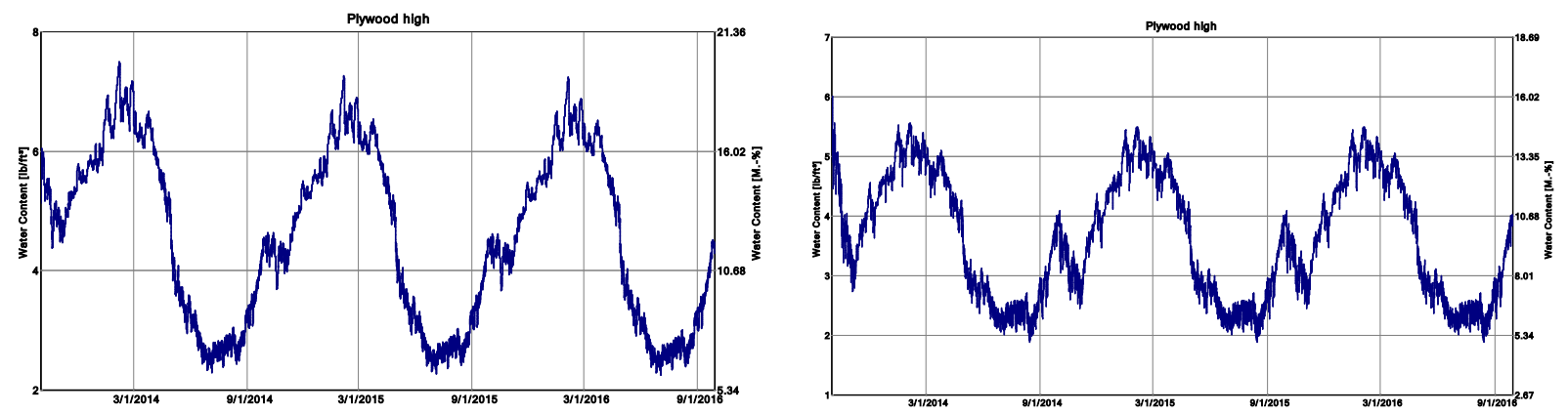

Figure 20. Round 1, Wall 2 sheathing MC in Minneapolis (Zone 6A), north (left) and south (right)

\subsubsection{Wall 3 (Vinyl-OSB)}

Table 9 describes the layers and their respective functions in the Round 1, Wall 3 configuration, and Figure 21 shows the layers from exterior to interior.

Table 9. Round 1, Wall 3 (Vinyl-OSB) Layers

\begin{tabular}{ll}
\hline Layer & Function \\
\hline Vinyl siding & provides exterior finish for aesthetics \\
\hline Asphalt saturated Kraft paper (building paper) & functions as air and water control layer \\
\hline OSB sheathing & provides structural support \\
\hline $\mathbf{2 x 4}$ framing & provides structural support \\
\hline Kraft-faced R-13 fiberglass batt & functions as thermal and vapor control layer \\
\hline Gypsum wall board & provides interior finish \\
\hline Latex paint & functions as vapor drive throttle \\
\hline
\end{tabular}




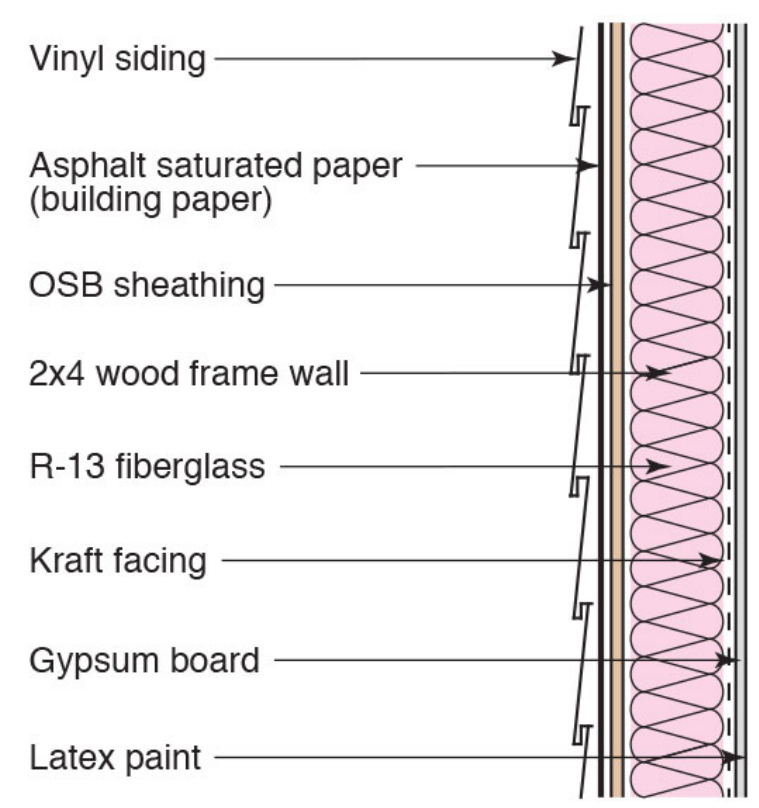

Figure 21. Round 1, Wall 3 (Vinyl-OSB) configuration

WUFI simulations are run on this wall on both north and south orientations in six climate zones; Figure 22 to Figure 27 show the MC graphs of the inner face of wall sheathing over a period of 3 years.
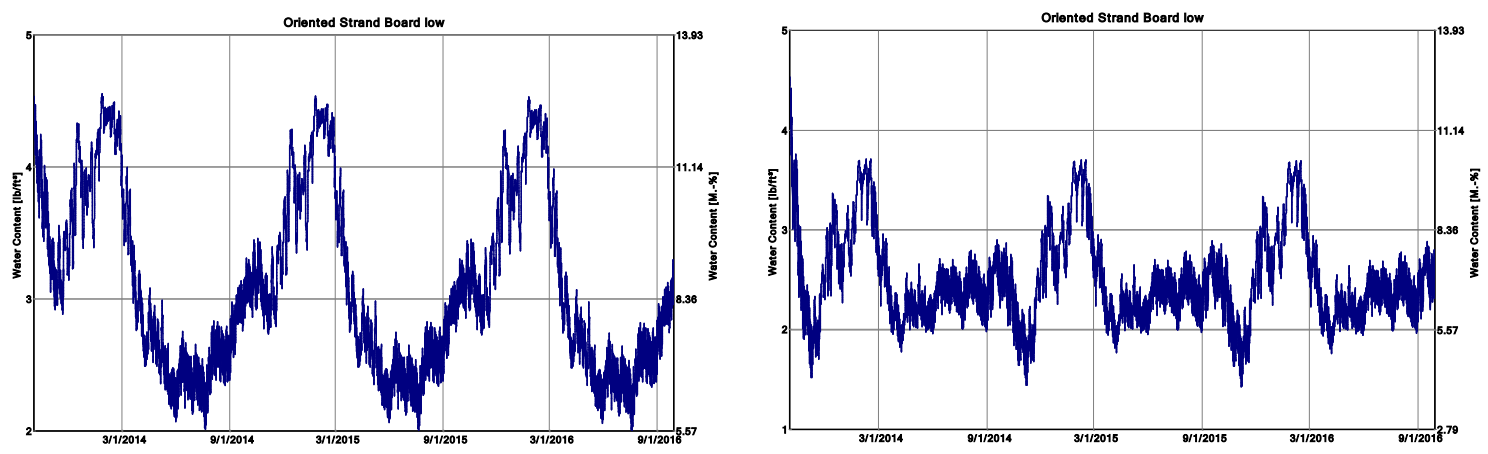

Figure 22. Round 1, Wall 3 sheathing MC in Houston (Zone 2A), north (left) and south (right)
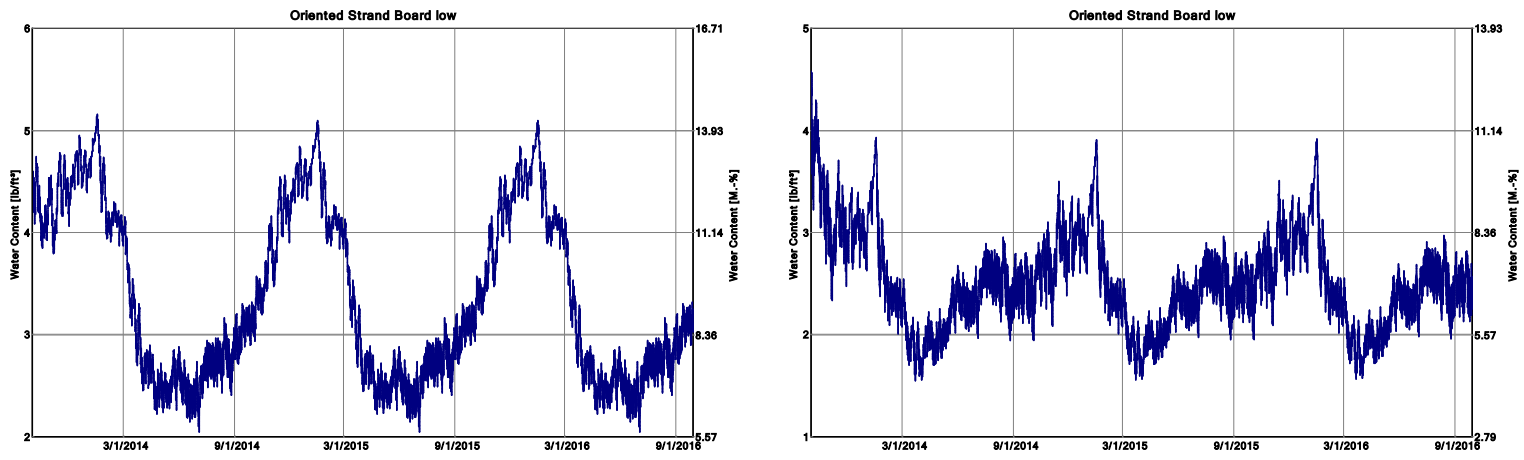

Figure 23. Round 1, Wall 3 sheathing MC in Atlanta (Zone 3A), north (left) and south (right) 

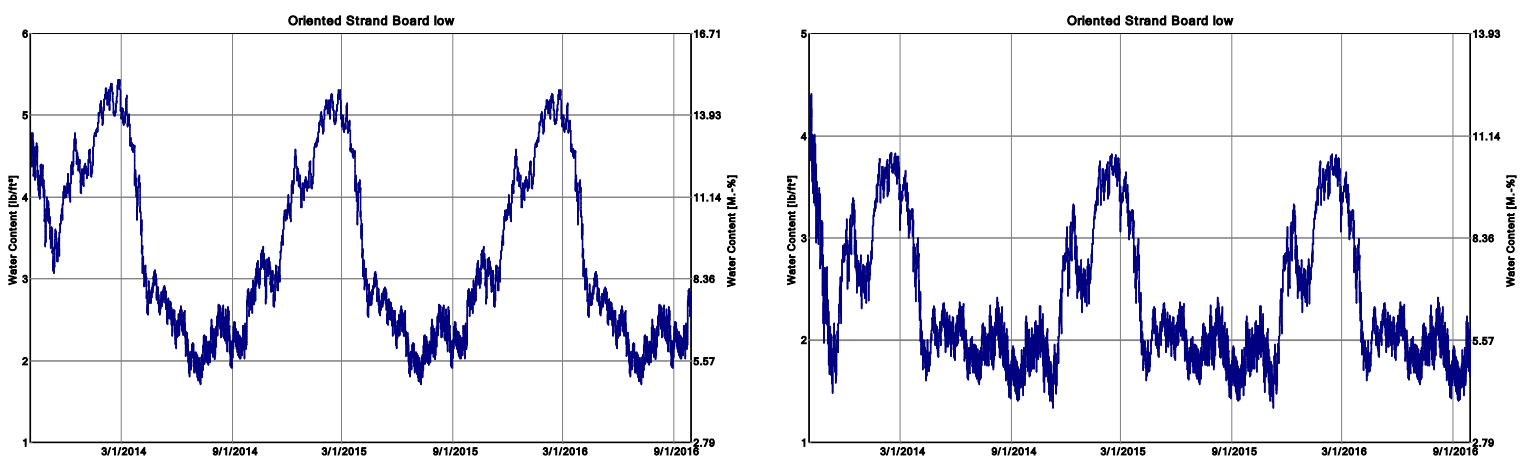

Figure 24. Round 1, Wall 3 sheathing MC in Kansas City (Zone 4A), north (left) and south (right)
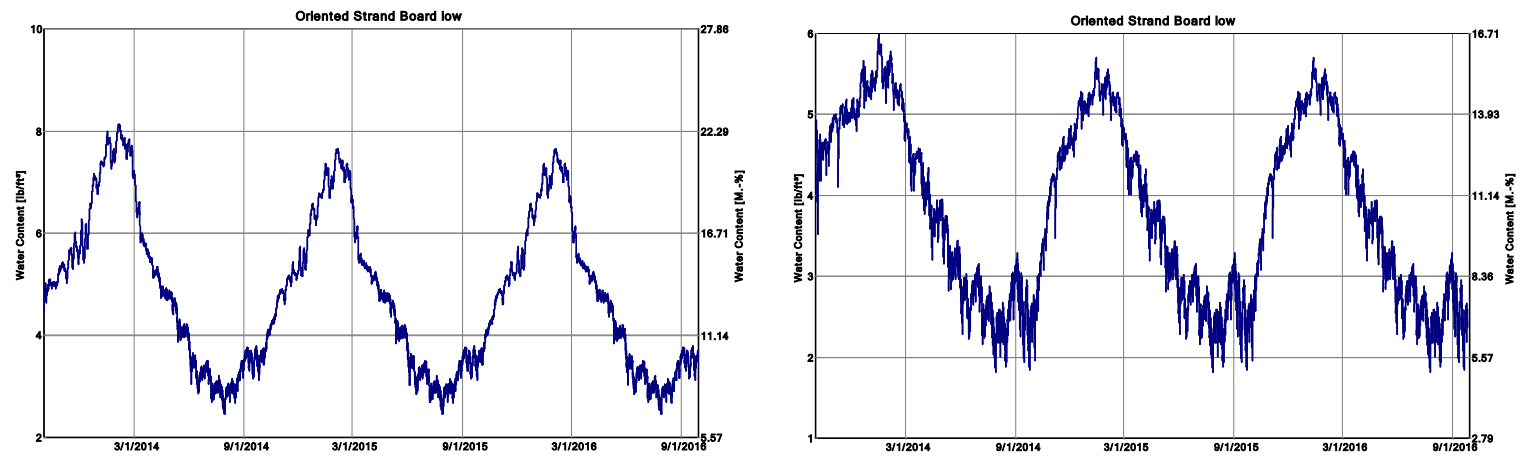

Figure 25. Round 1, Wall 3 sheathing MC in Seattle (Zone 4C), north (left) and south (right)
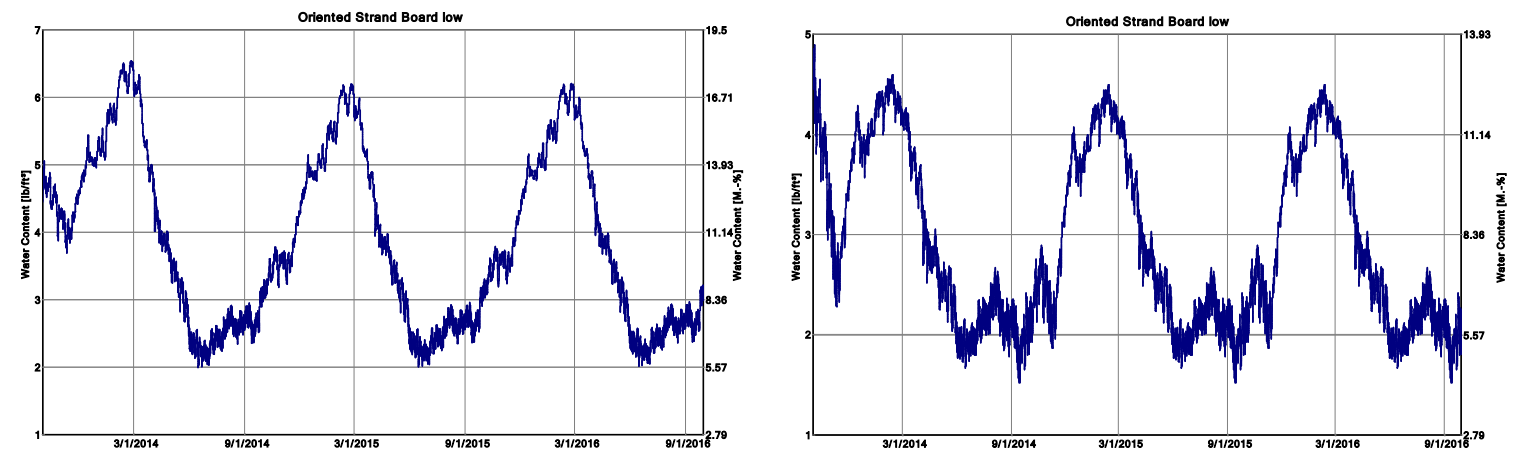

Figure 26. Round 1, Wall 3 sheathing MC in Chicago (Zone 5A), north (left) and south (right)
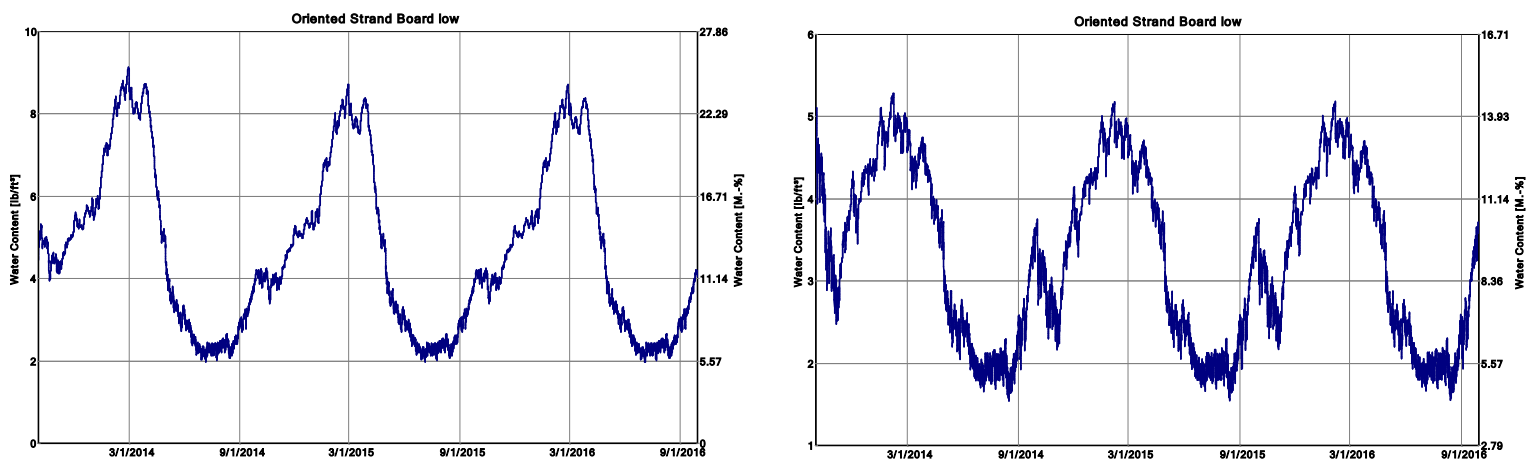

Figure 27. Round 1, Wall 3 sheathing MC in Minneapolis (Zone 6A), north (left) and south (right) 


\subsubsection{Wall 4 (Brick-OSB)}

Table 10 describes the layers and their respective functions in the Round 1, Wall 4 configuration, and Figure 28 shows the layers from exterior to interior.

Table 10. Round 1, Wall 4 (Brick-OSB) Layers

\begin{tabular}{ll}
\hline Layer & Function \\
\hline Brick veneer & provides exterior finish for aesthetics \\
\hline Asphalt saturated Kraft paper (building paper) & functions as air and water control layer \\
\hline OSB sheathing & provides structural support \\
\hline $\mathbf{2 x 4}$ framing & provides structural support \\
\hline Kraft-faced R-13 fiberglass batt & functions as thermal and vapor control layer \\
\hline Gypsum wall board & provides interior finish \\
\hline Latex paint & functions as vapor drive throttle \\
\hline
\end{tabular}

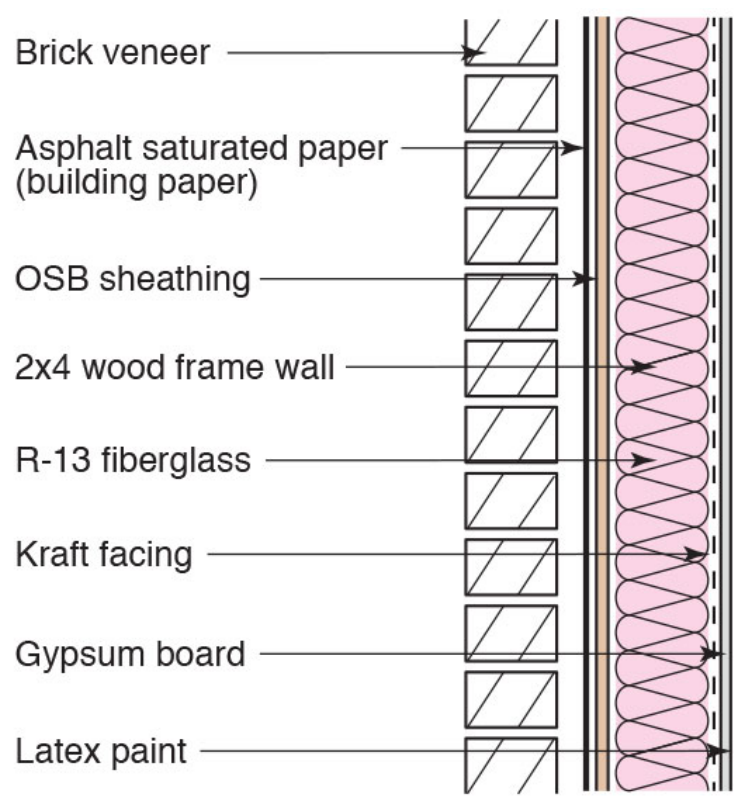

Figure 28. Round 1, Wall 4 (Brick-OSB) configuration

WUFI simulations are run on this wall on both north and south orientations in six climate zones; Figure 29 to Figure 34 show the MC graphs of the inner face of wall sheathing over a period of 3 years. 

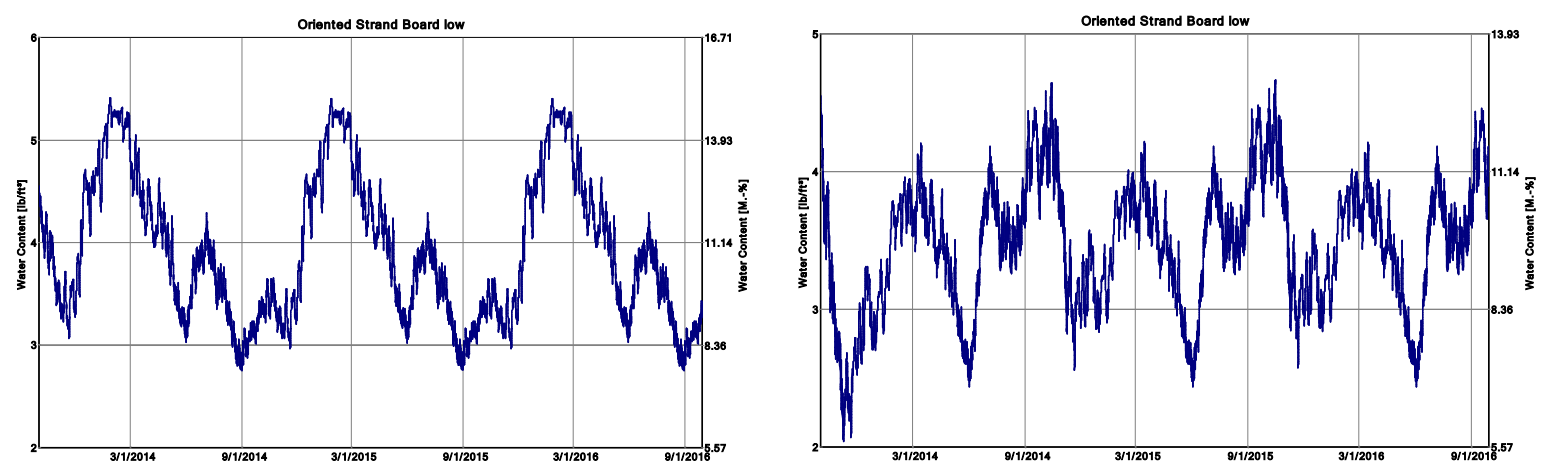

Figure 29. Round 1, Wall 4 sheathing MC in Houston (Zone 2A), north (left) and south (right)
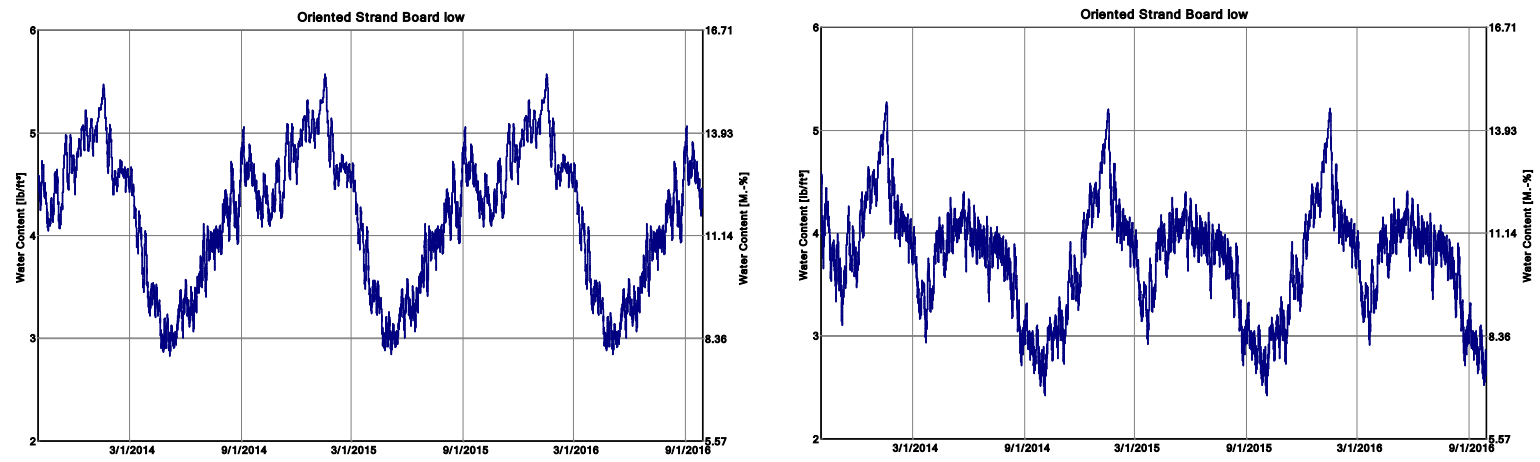

Figure 30. Round 1, Wall 4 sheathing MC in Atlanta (Zone 3A), north (left) and south (right)
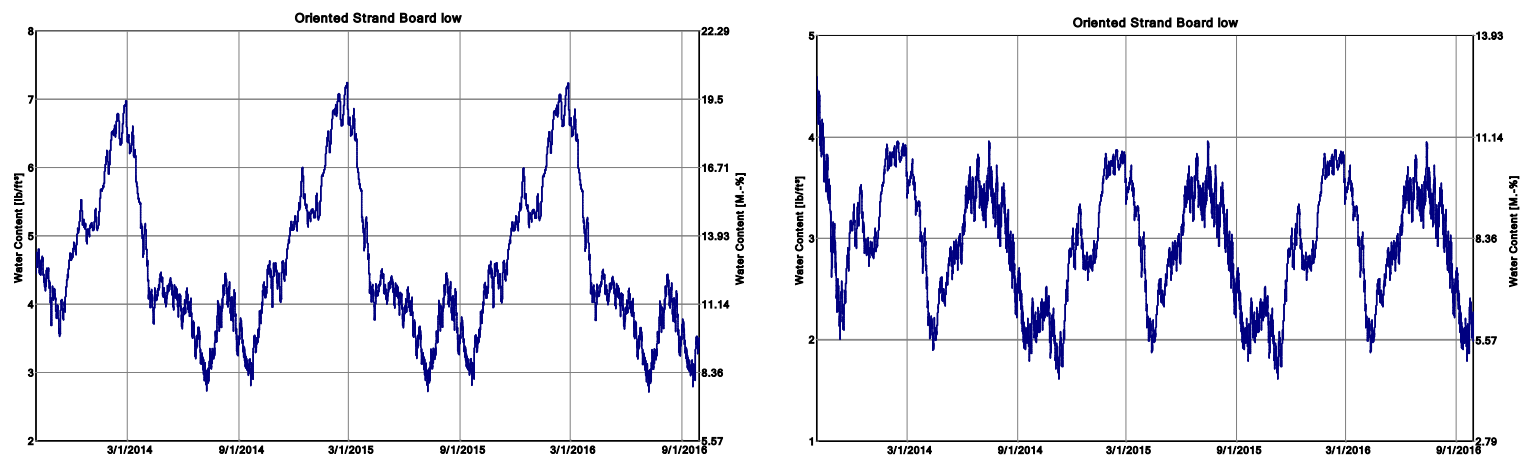

Figure 31. Round 1, Wall 4 sheathing MC in Kansas City (Zone 4A), north (left) and south (right)
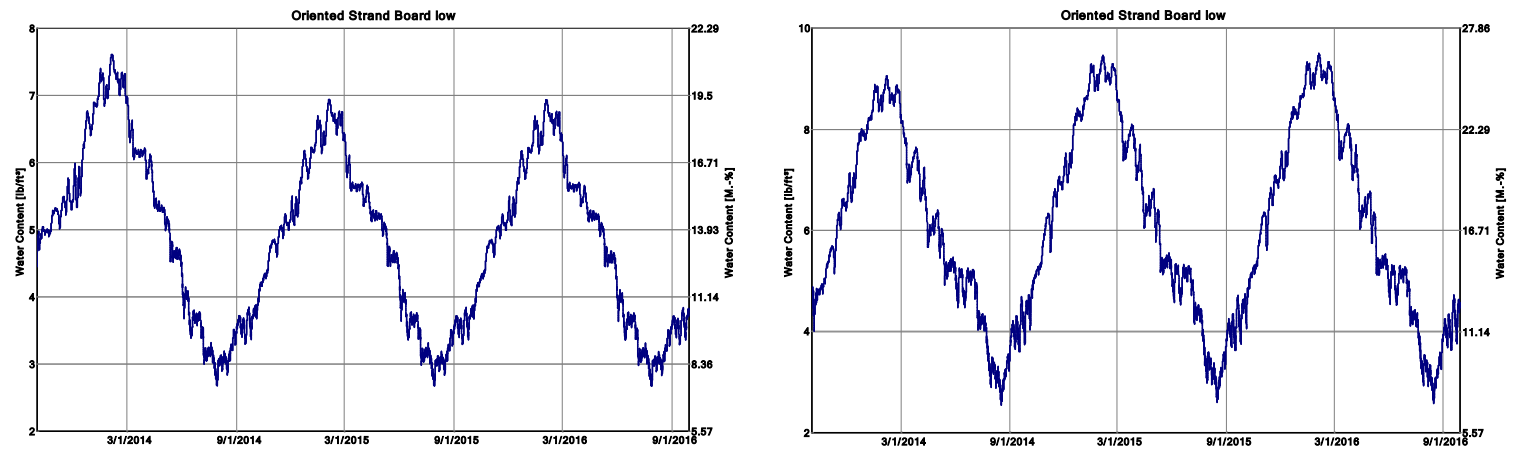

Figure 32. Round 1, Wall 4 sheathing MC in Seattle (Zone 4C), north (left) and south (right) 

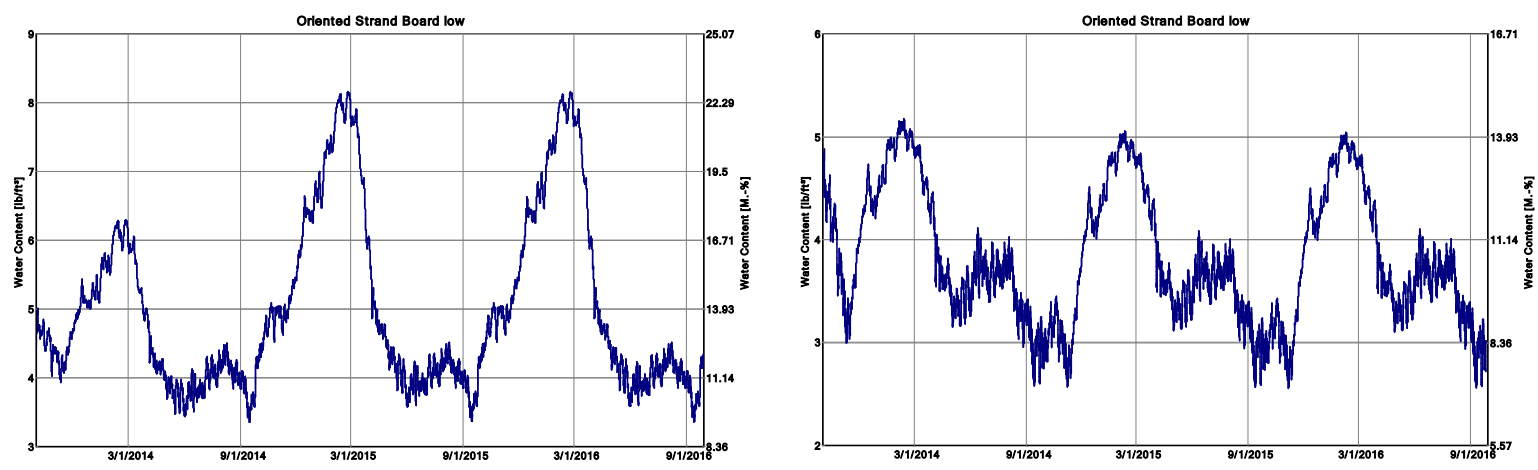

Figure 33. Round 1, Wall 4 sheathing MC in Chicago (Zone 5A), north (left) and south (right)
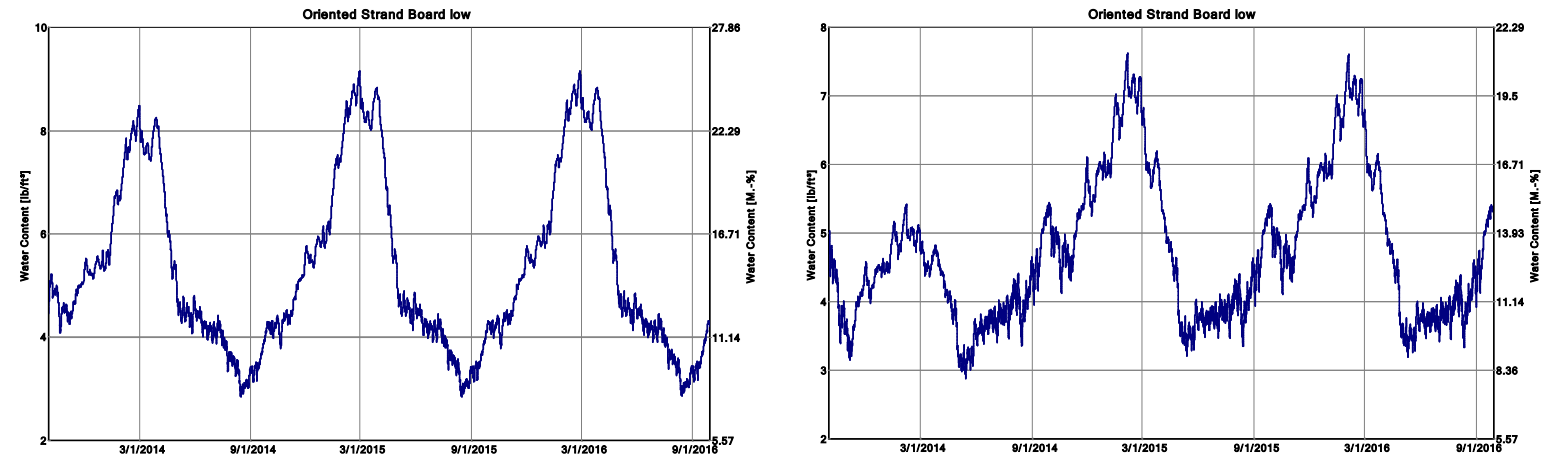

Figure 34. Round 1, Wall 4 sheathing MC in Minneapolis (Zone 6A), north (left) and south (right)

\subsubsection{Wall 5 (Stucco-OSB)}

Table 11 describes the layers and their respective functions in the Round 1, Wall 5 configuration, and Figure 35 shows the layers from exterior to interior.

Table 11. Round 1, Wall 5 (Stucco-OSB) Layers

\begin{tabular}{ll}
\hline Layer & Function \\
\hline Stucco & provides exterior finish for aesthetics \\
\hline $\begin{array}{l}\text { 2 layers asphalt saturated Kraft paper } \\
\text { (building paper) }\end{array}$ & functions as air and water control layer \\
\hline OSB sheathing & provides structural support \\
\hline $\mathbf{2 x 4}$ framing & provides structural support \\
\hline Kraft-faced R-13 fiberglass batt & functions as thermal and vapor control layer \\
\hline Gypsum wall board & provides interior finish \\
\hline Latex paint & functions as vapor drive throttle \\
\hline
\end{tabular}




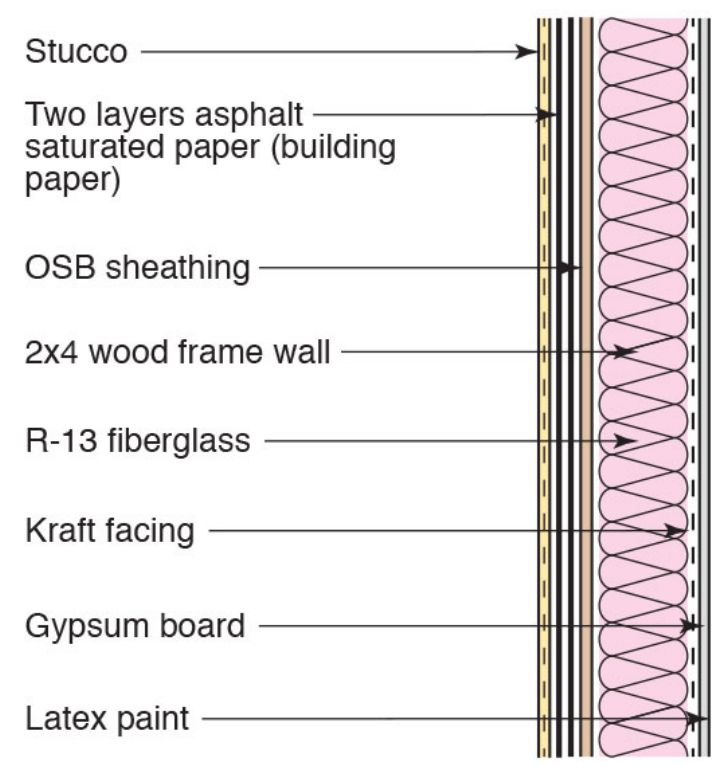

Figure 35. Round 1, Wall 5 (Stucco-OSB) configuration

WUFI simulations are run on this wall on both north and south orientations in six climate zones; Figure 36 to Figure 41 show the MC graphs of the inner face of wall sheathing over a period of 3 years.
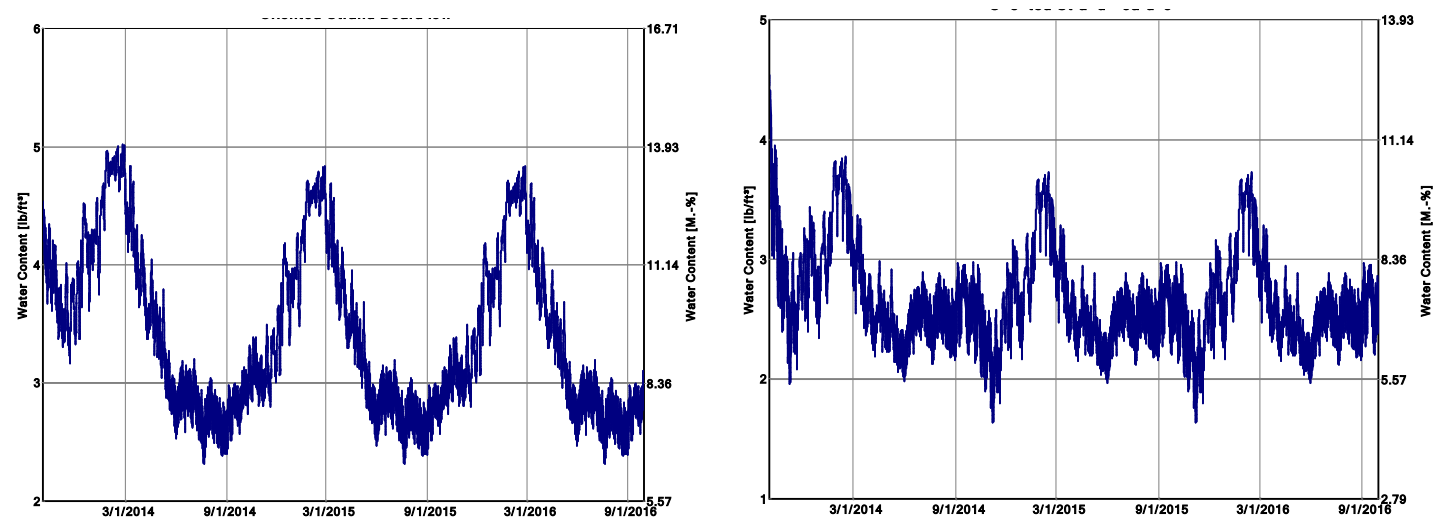

Figure 36. Round 1, Wall 5 sheathing MC in Houston (Zone 2A), north (left) and south (right)
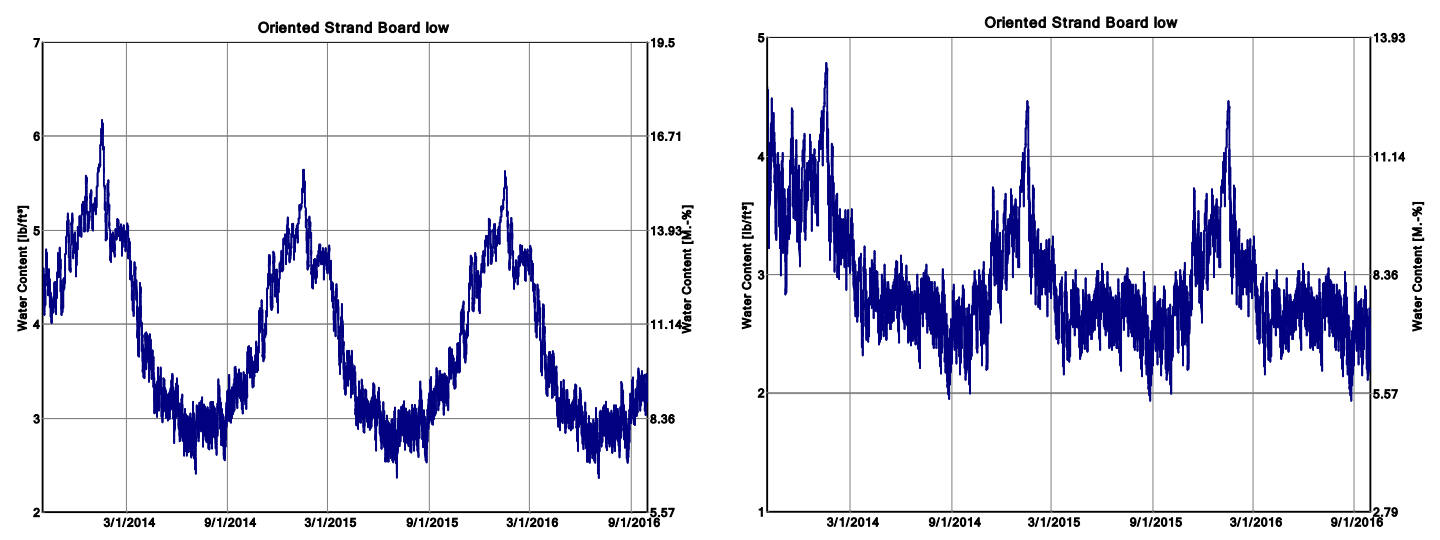

Figure 37. Round 1, Wall 5 sheathing MC in Atlanta (Zone 3A), north (left) and south (right) 

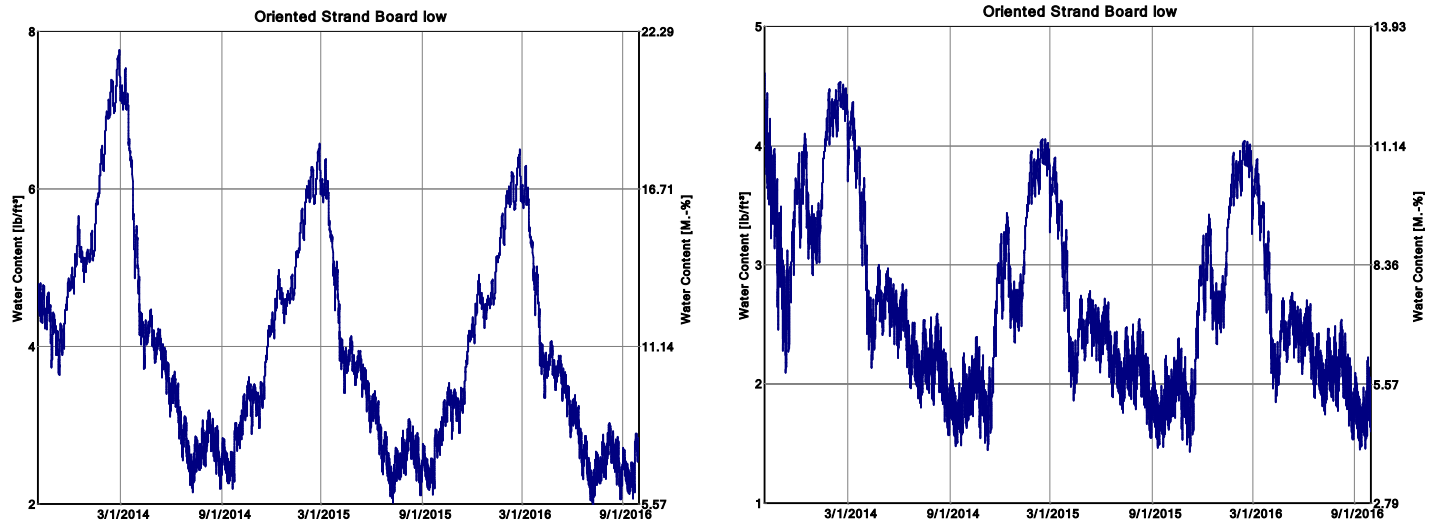

Figure 38. Round 1, Wall 5 sheathing MC in Kansas City (Zone 4A), north (left) and south (right)
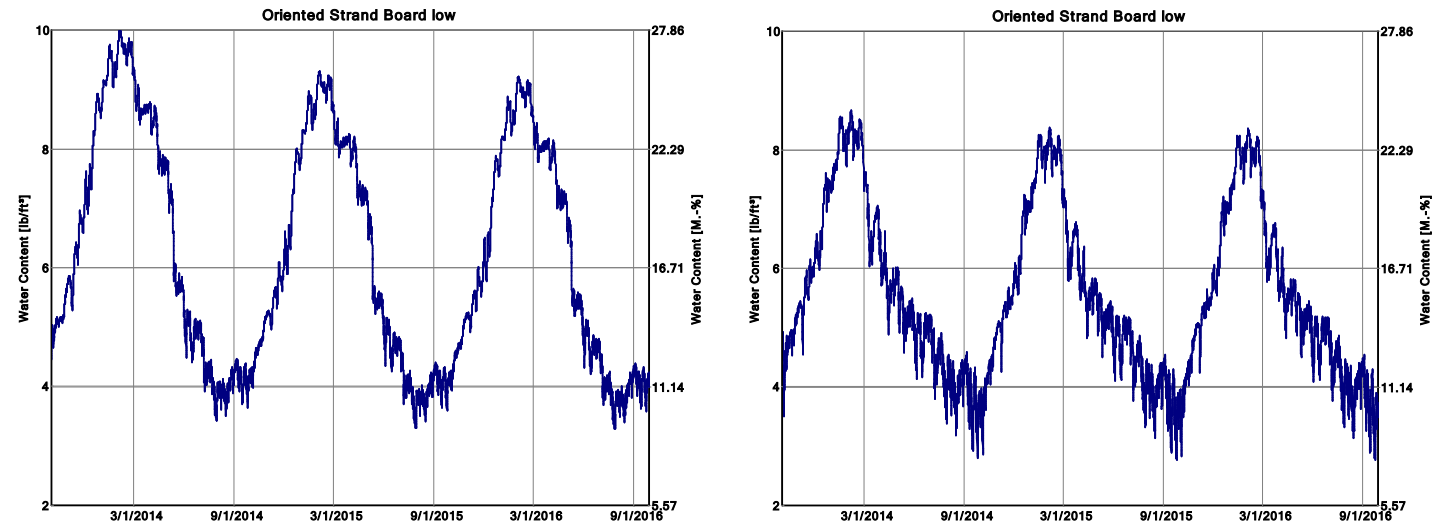

Figure 39. Round 1, Wall 5 sheathing MC in Seattle (Zone 4C), north (left) and south (right)
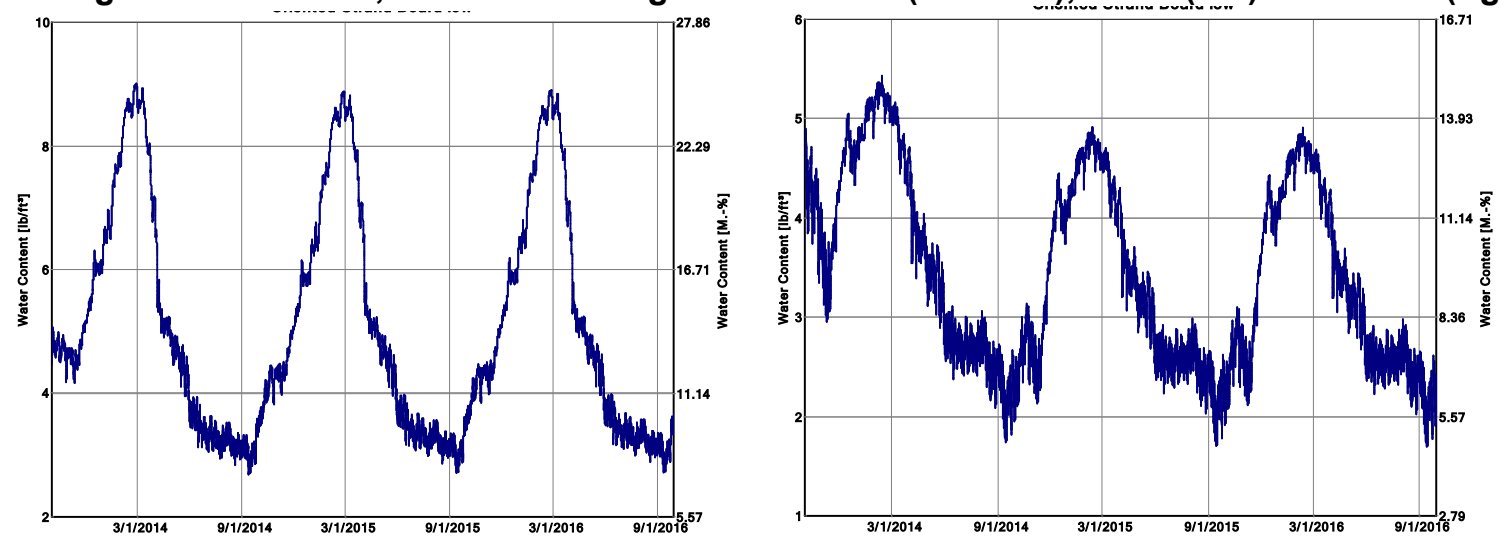

Figure 40. Round 1, Wall 5 sheathing MC in Chicago (Zone 5A), north (left) and south (right) 

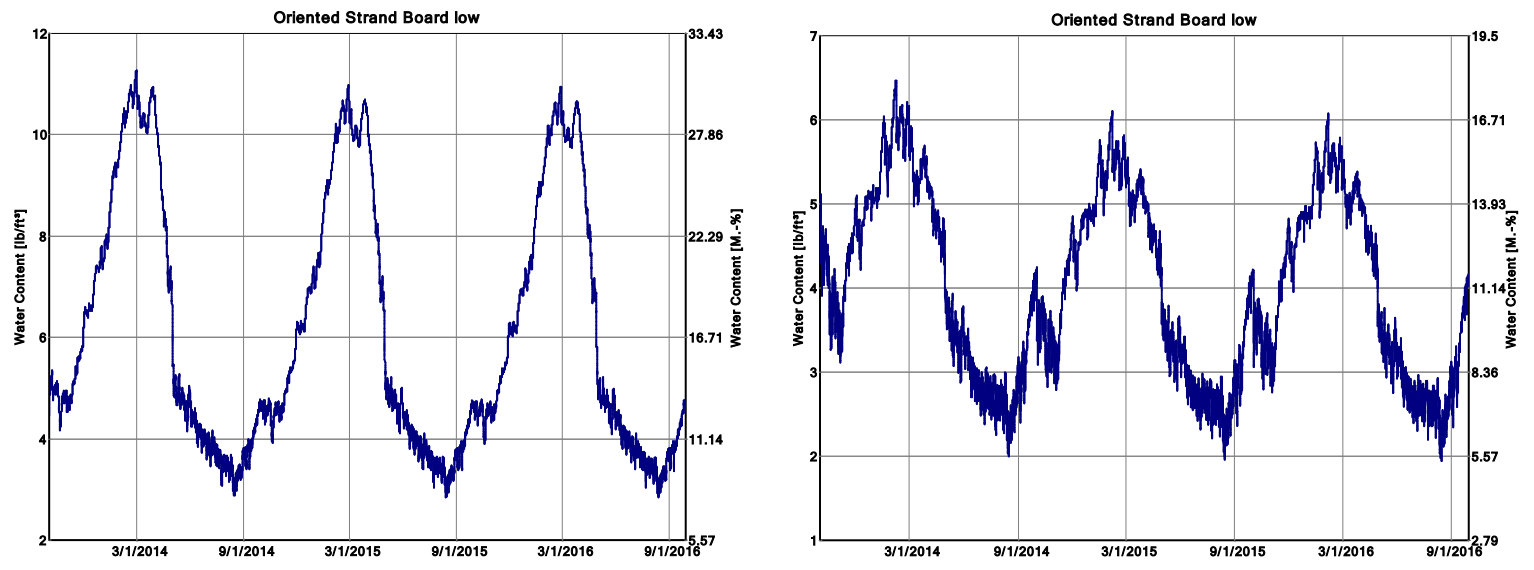

Figure 41. Round 1, Wall 5 sheathing MC in Minneapolis (Zone 6A), north (left) and south (right)

\subsubsection{Wall 6 (Vented Stucco-OSB)}

Table 12 describes the layers and their respective functions in the Round 1, Wall 6 configuration, and Figure 42 shows the layers from exterior to interior.

Table 12. Round 1, Wall 6 (Vented Stucco-OSB) Layers

\begin{tabular}{ll}
\hline Layer & Function \\
\hline Stucco & provides exterior finish for aesthetics \\
\hline $\begin{array}{l}1 \text { layer asphalt saturated Kraft paper } \\
\text { (building paper) }\end{array}$ & provides backing for stucco \\
\hline $\begin{array}{l}\text { Polypropylene drainage mat ( } 1 / 2 \text { inch) } \\
\text { Another layer asphalt saturated Kraft paper } \\
\text { (building paper) }\end{array}$ & provides drainage and ventilation gap \\
\hline OSB sheathing & functions as air and water control layer \\
\hline 2x4 framing & provides structural support \\
\hline Kraft-faced R-13 fiberglass batt & provides structural support \\
\hline Gypsum wall board & functions as thermal and vapor control layer \\
\hline Latex paint & provides interior finish \\
\hline
\end{tabular}




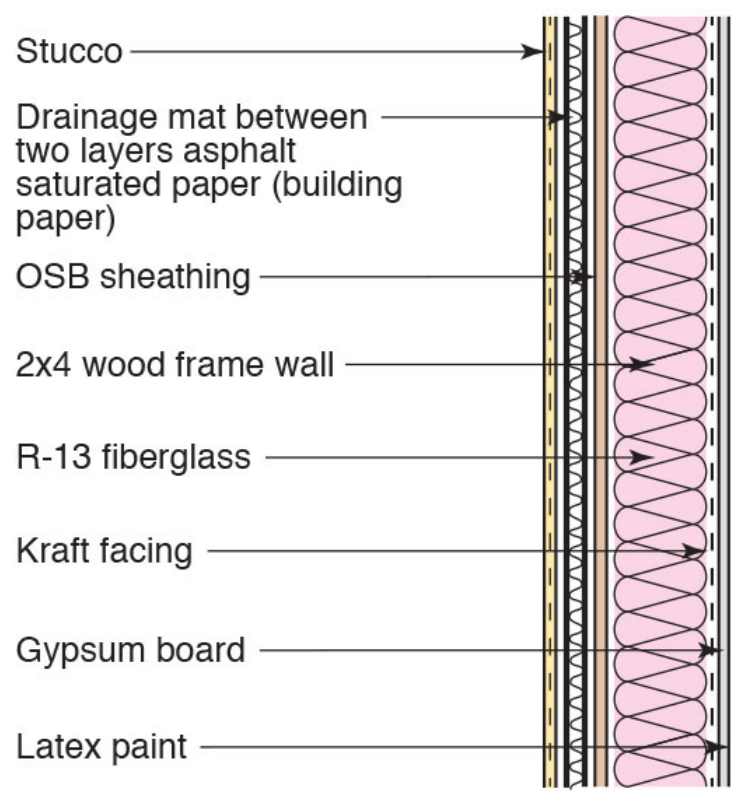

Figure 42. Round 1, Wall 6 (vented stucco-OSB) configuration

WUFI simulations are run on this wall on both north and south orientations in six climate zones; Figure 43 to Figure 48 show the MC graphs of the inner face of wall sheathing over a period of 3 years.
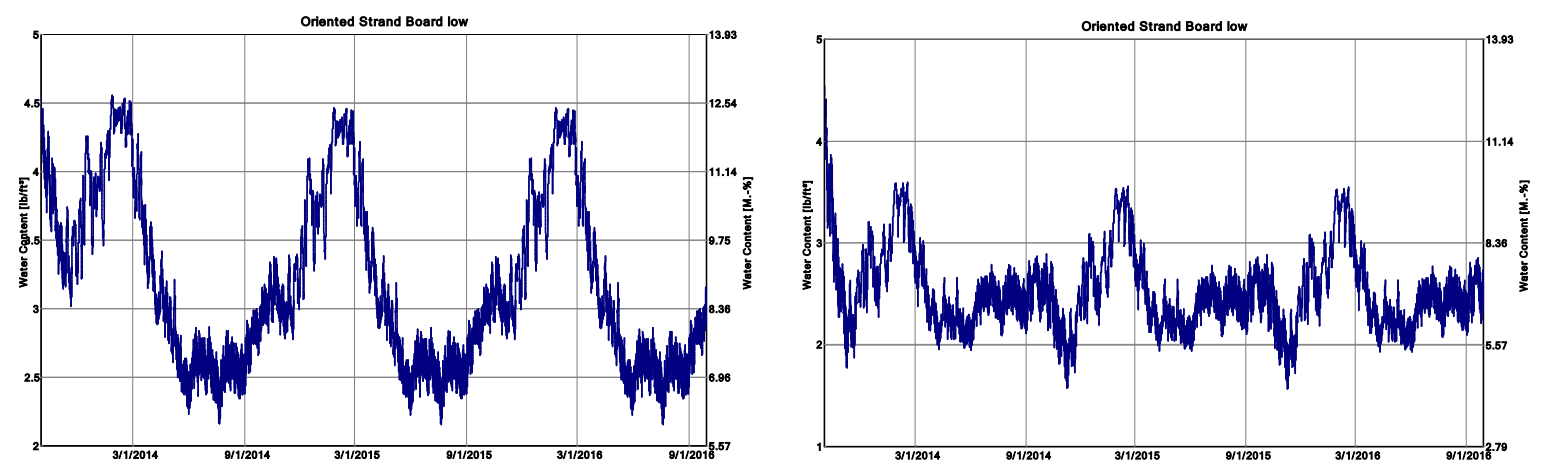

Figure 43. Round 1, Wall 6 sheathing MC in Houston (Zone 2A), north (left) and south (right)
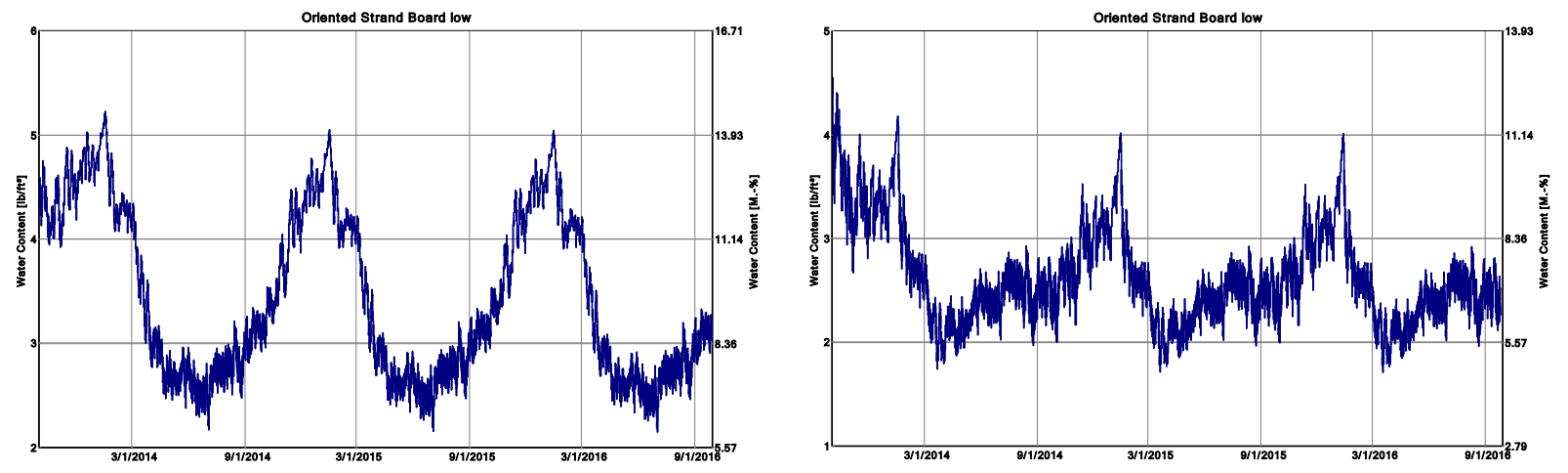

Figure 44. Round 1, Wall 6 sheathing MC in Atlanta (Zone 3A), north (left) and south (right) 

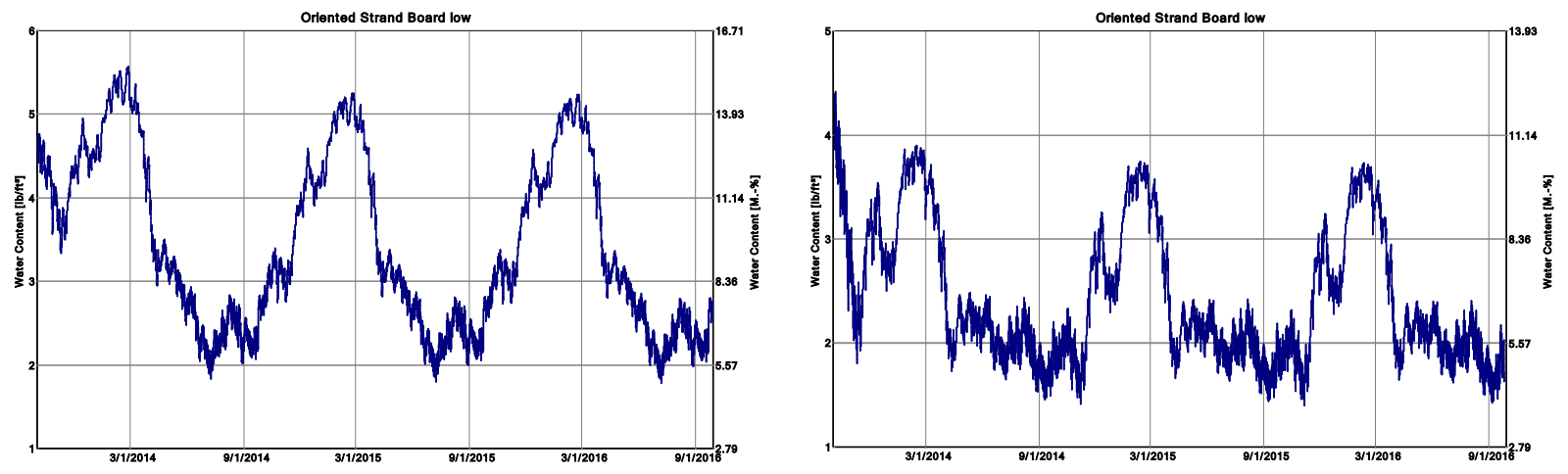

Figure 45. Round 1, Wall 6 sheathing MC in Kansas City (Zone 4A), north (left) and south (right)
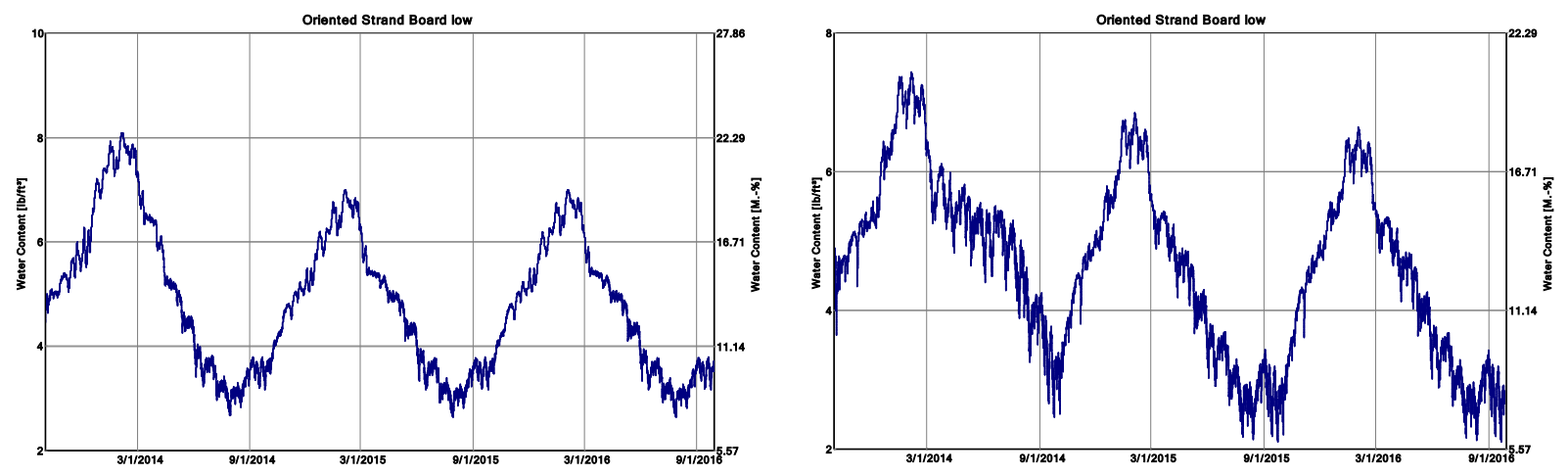

Figure 46. Round 1, Wall 6 sheathing MC in Seattle (Zone 4C), north (left) and south (right)
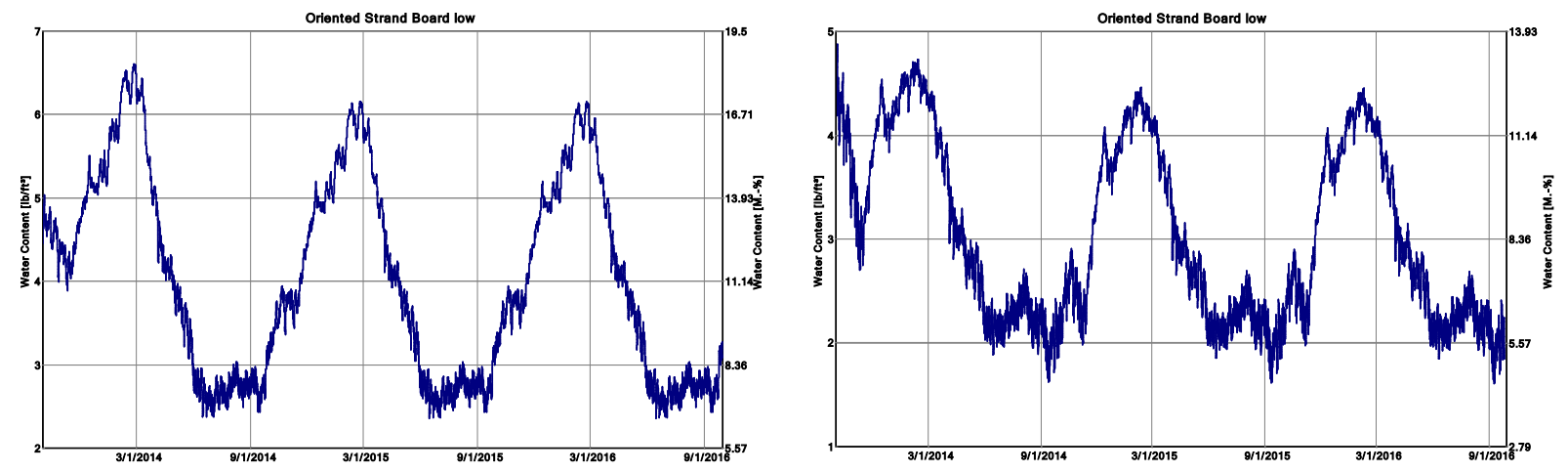

Figure 47. Round 1, Wall 6 sheathing MC in Chicago (Zone 5A), north (left) and south (right) 

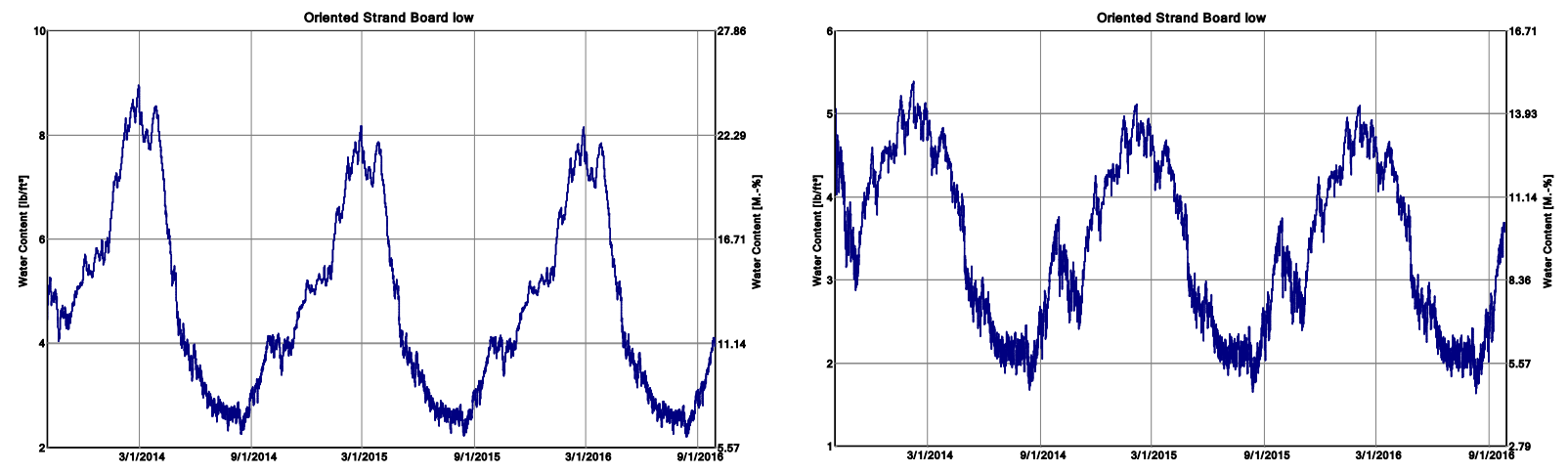

Figure 48. Round 1, Wall 6 sheathing MC in Minneapolis (Zone 6A), north (left) and south (right)

\subsection{Round 2 (2x6 Framing, R-19 Fiberglass)}

In the second round, $2 \times 4$ framing with R-13 Kraft faced fiberglass batts is replaced with $2 \times 6$ framing with R-19 Kraft faced fiberglass batt in each of the wall systems.

\subsubsection{Wall 1 (Wood Siding-Ply)}

Table 13 describes the layers and their respective functions in the Round 2, Wall 1 configuration, and Figure 49 shows the layers from exterior to interior.

Table 13. Round 2, Wall 1 (Wood Siding-Ply) Layers

\begin{tabular}{ll}
\hline Layer & Function \\
\hline Latex painted wood siding & provides exterior finish for aesthetics \\
\hline Asphalt saturated Kraft paper (building paper) & functions as air and water control layer \\
\hline Plywood sheathing & provides structural support \\
\hline 2x6 framing & provides structural support \\
\hline Kraft-faced R-19 fiberglass batt & functions as thermal and vapor control layer \\
\hline Gypsum wall board & provides interior finish \\
\hline Latex paint & functions as vapor drive throttle \\
\hline
\end{tabular}




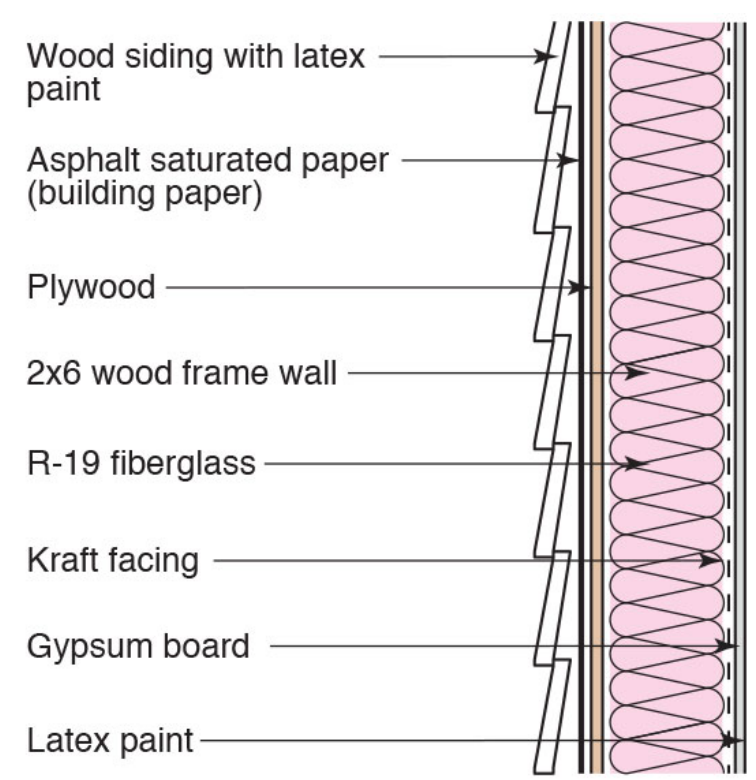

Figure 49. Round 2, Wall 1 (wood siding-ply) configuration

WUFI simulations are run on this wall on both north and south orientations in six climate locations; Figure 50 to Figure 55 show the MC graphs of the inner face of wall sheathing over a period of 3 years.
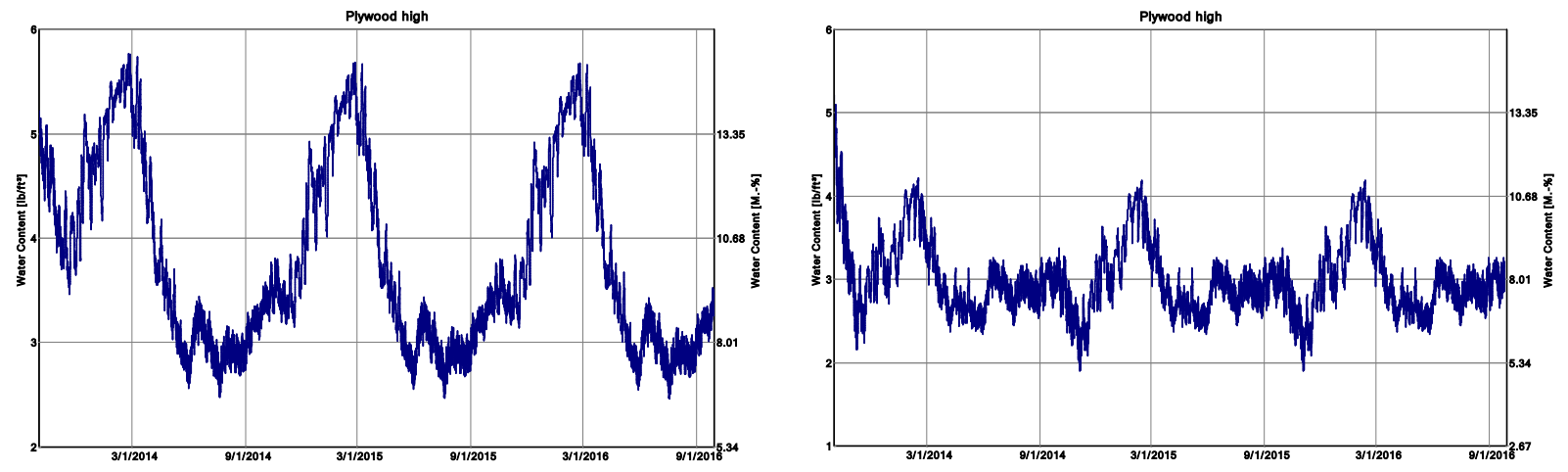

Figure 50. Round 2, Wall 1 sheathing MC in Houston (Zone 2A), north (left) and south (right)
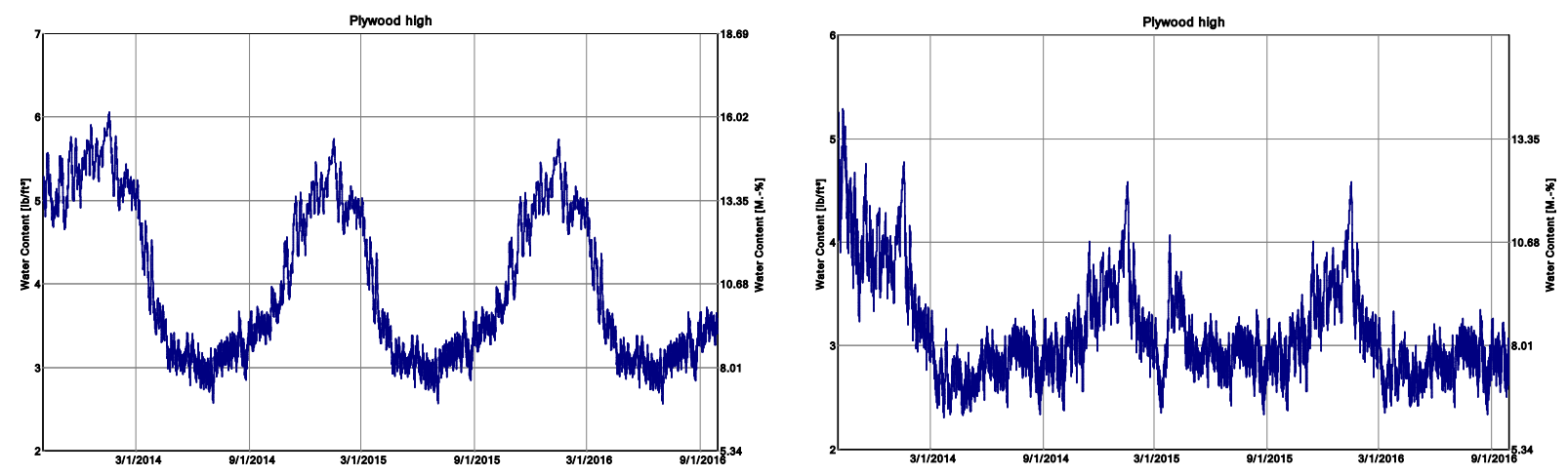

Figure 51. Round 2, Wall 1 sheathing MC in Atlanta (Zone 3A), north (left) and south (right) 

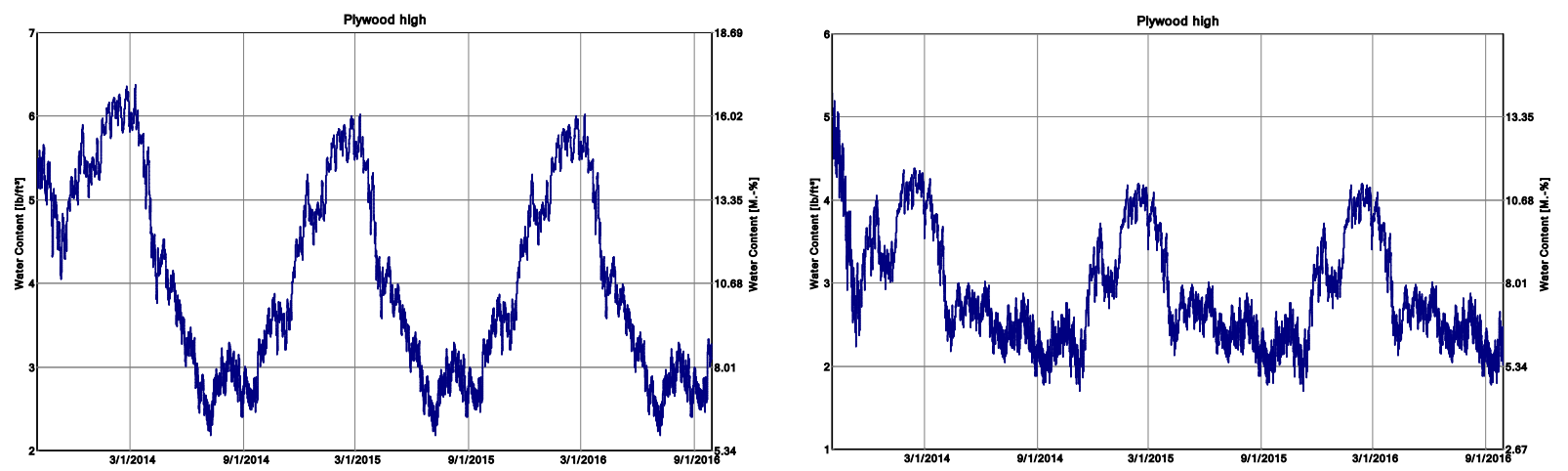

Figure 52. Round 2, Wall 1 sheathing MC in Kansas City (Zone 4A), north (left) and south (right)
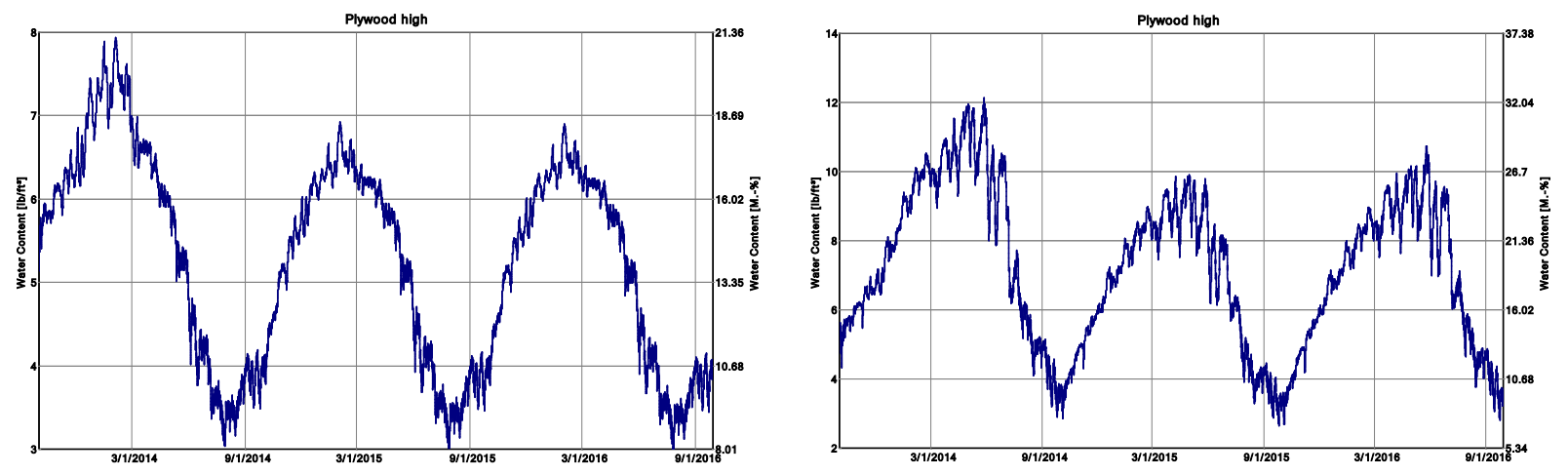

Figure 53. Round 2, Wall 1 sheathing MC in Seattle (Zone 4C), north (left) and south (right)
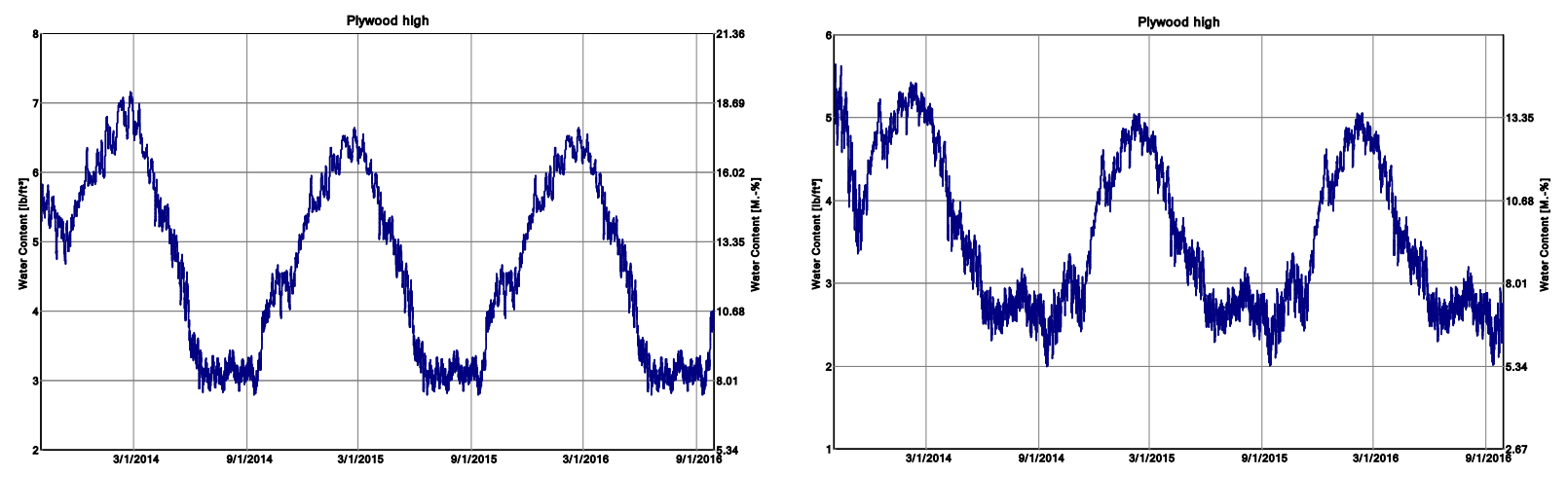

Figure 54. Round 2, Wall 1 sheathing MC in Chicago (Zone 5A), north (left) and south (right) 

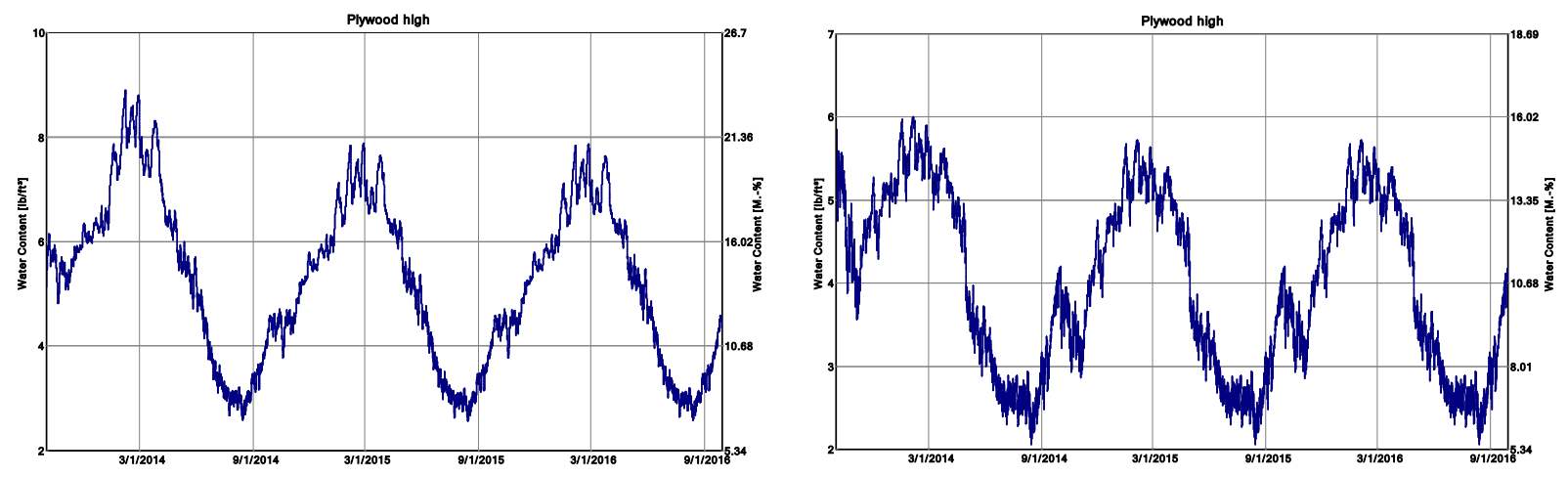

Figure 55. Round 2, Wall 1 sheathing MC in Minneapolis (Zone 6A), north (left) and south (right)

\subsubsection{Wall 2 (Vinyl Siding-Ply)}

Table 14 describes the layers and their respective functions in the Round 2, Wall 2 configuration, and Figure 56 shows the layers from exterior to interior.

Table 14. Round 2, Wall 2 (Vinyl Siding-Ply) Layers

\begin{tabular}{ll}
\hline Layer & Function \\
\hline Vinyl siding & provides exterior finish for aesthetics \\
\hline Asphalt saturated Kraft paper (building paper) & functions as air and water control layer \\
\hline Plywood sheathing & provides structural support \\
\hline $\mathbf{2 x 6}$ framing & provides structural support \\
\hline Kraft-faced R-19 fiberglass batt & functions as thermal and vapor control layer \\
\hline Gypsum wall board & provides interior finish \\
\hline Latex paint & functions as vapor drive throttle \\
\hline
\end{tabular}




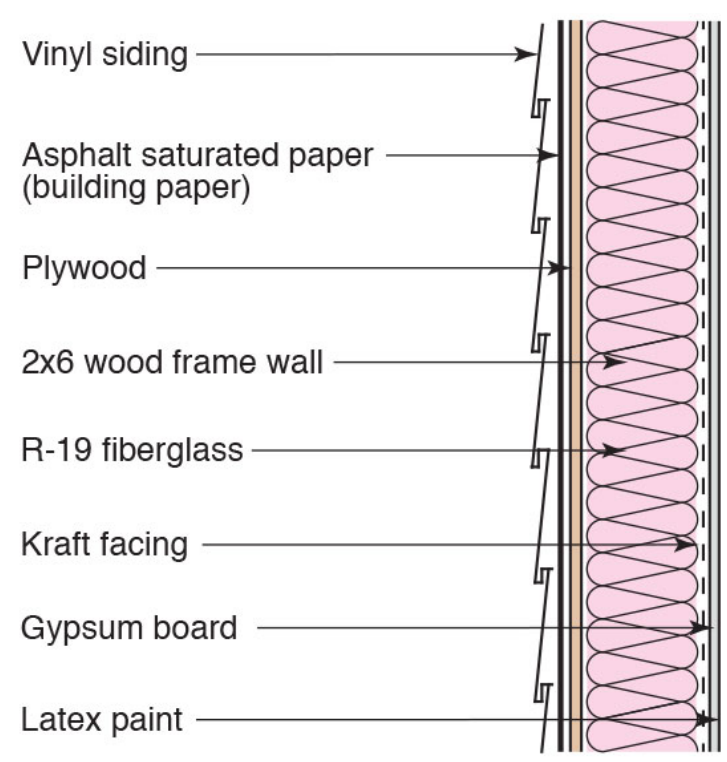

Figure 56. Round 2, Wall 2 (vinyl siding-ply) configuration

WUFI simulations are run on this wall on both north and south orientations in six climate zones; Figure 57 to Figure 62 show the MC graphs of the inner face of wall sheathing over a period of 3 years.
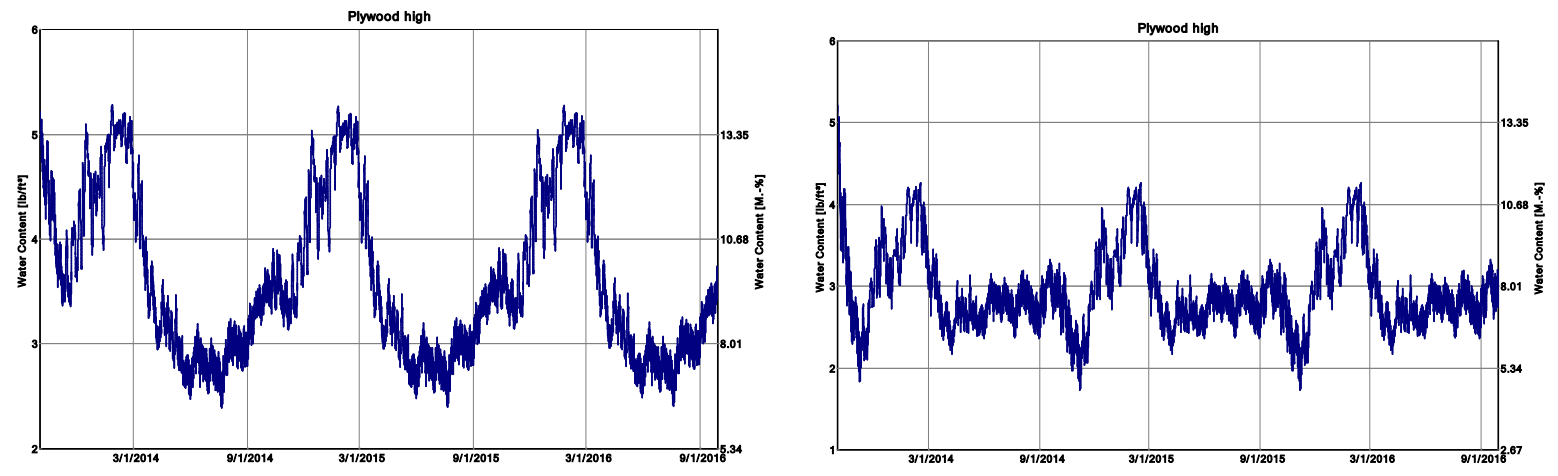

Figure 57. Round 2, Wall 2 sheathing MC in Houston (Zone 2A), north (left) and south (right)
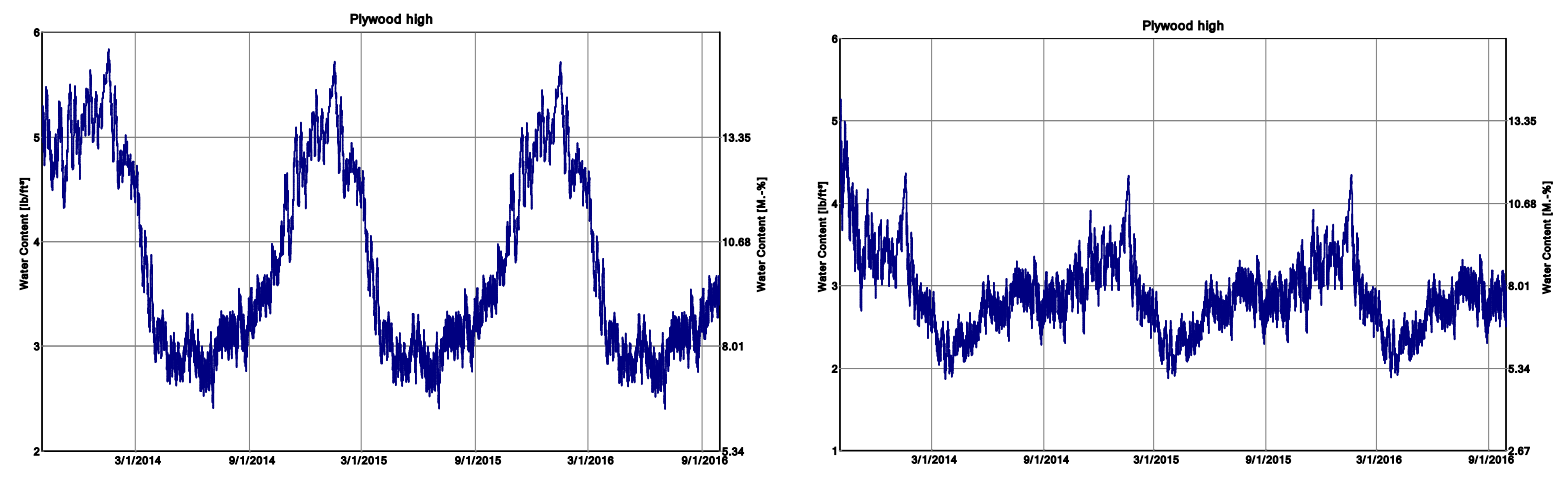

Figure 58. Round 2, Wall 2 sheathing MC in Atlanta (Zone 3A), north (left) and south (right) 

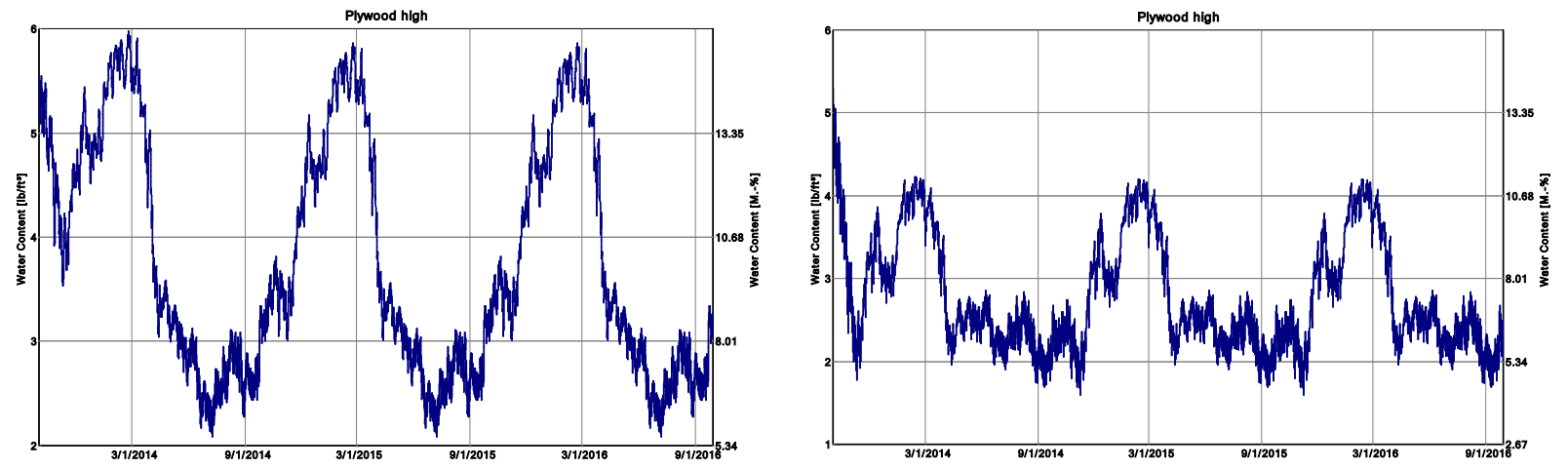

Figure 59. Round 2, Wall 2 sheathing MC in Kansas City (Zone 4A), north (left) and south (right)
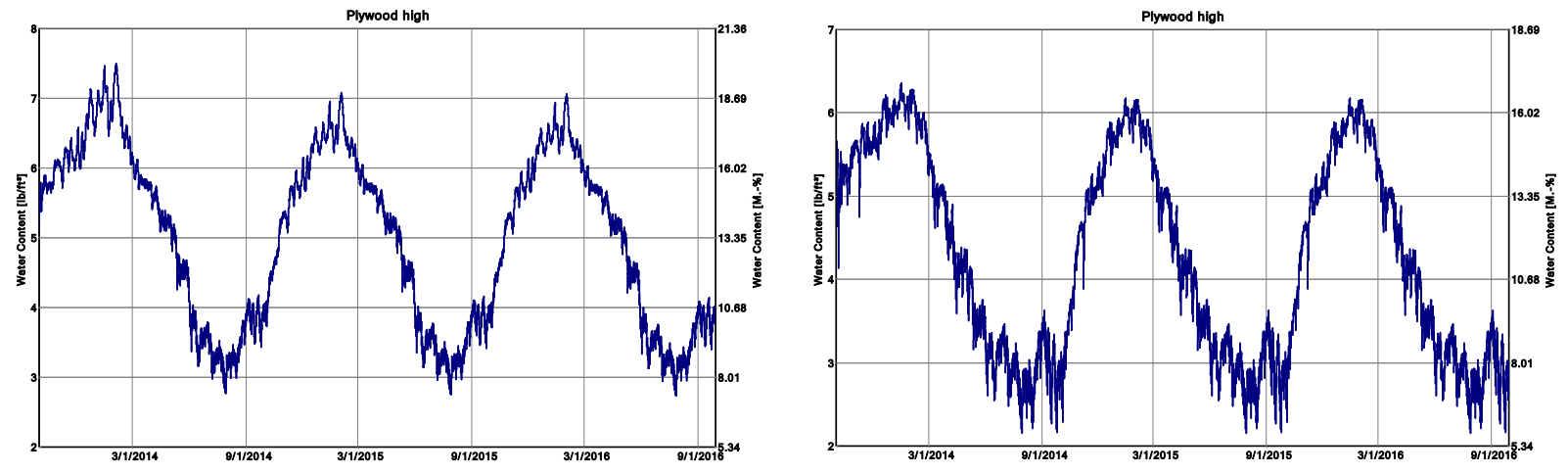

Figure 60. Round 2, Wall 2 sheathing MC in Seattle (Zone 4C), north (left) and south (right)
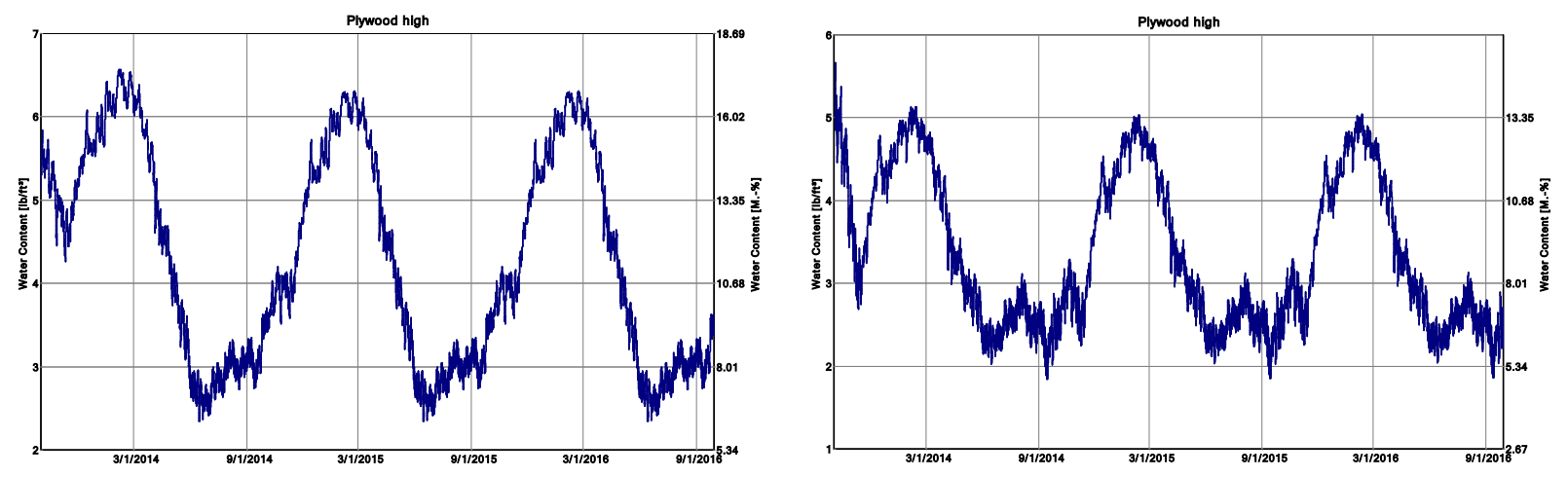

Figure 61. Round 2, Wall 2 sheathing MC in Chicago (Zone 5A), north (left) and south (right) 

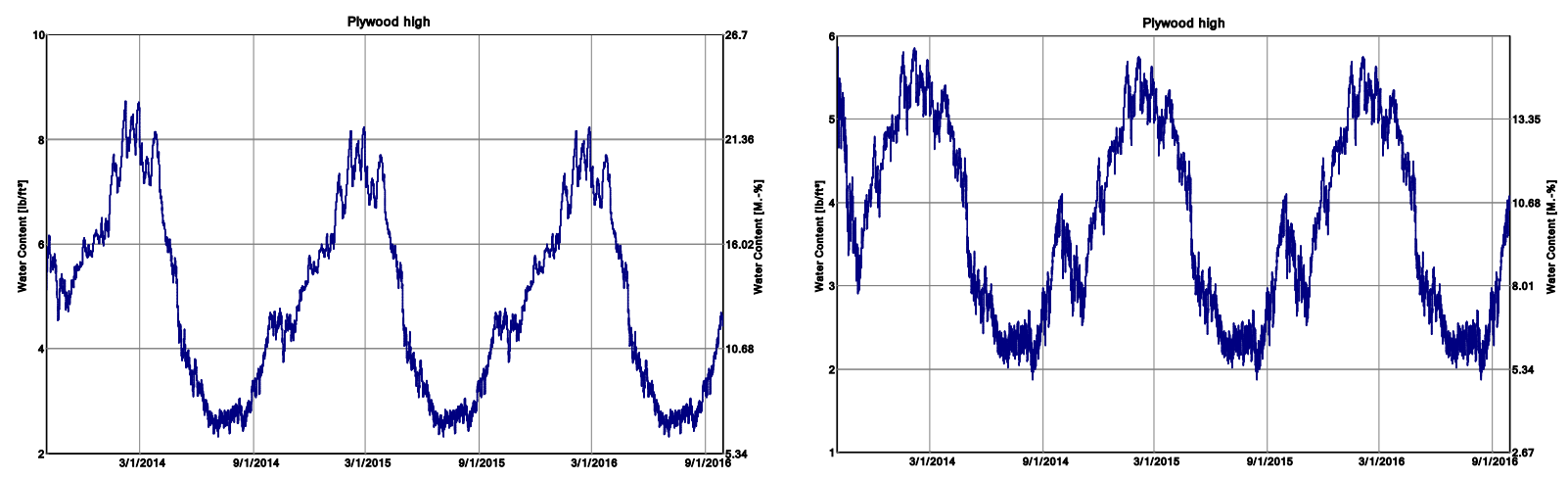

Figure 62. Round 2, Wall 2 sheathing MC in Minneapolis (Zone 6A), north (left) and south (right)

\subsubsection{Wall 3 (Vinyl-OSB)}

Table 15 describes the layers and their respective functions in the Round 2, Wall 3 configuration, and Figure 63 shows the layers from exterior to interior.

Table 15. Round 2, Wall 3 (Vinyl-OSB) layers

\begin{tabular}{ll}
\hline Layer & Function \\
\hline Vinyl siding & provides exterior finish for aesthetics \\
\hline Asphalt saturated Kraft paper (building paper) & functions as air and water control layer \\
\hline OSB sheathing & provides structural support \\
\hline $\mathbf{2 x 6}$ framing & provides structural support \\
\hline Kraft-faced R-19 fiberglass batt & functions as thermal and vapor control layer \\
\hline Gypsum wall board & provides interior finish \\
\hline Latex paint & functions as vapor drive throttle \\
\hline
\end{tabular}




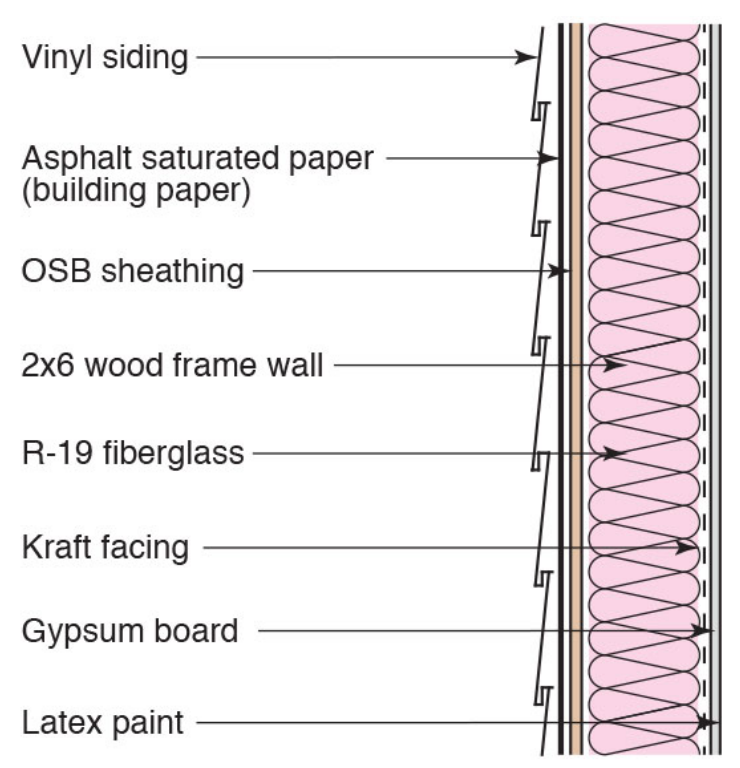

Figure 63. Round 2, Wall 3 (Vinyl-OSB) configuration

WUFI simulations are run on this wall on both north and south orientations in six climate zones; Figure 64 to Figure 69 show the MC graphs of the inner face of wall sheathing over a period of 3 years.
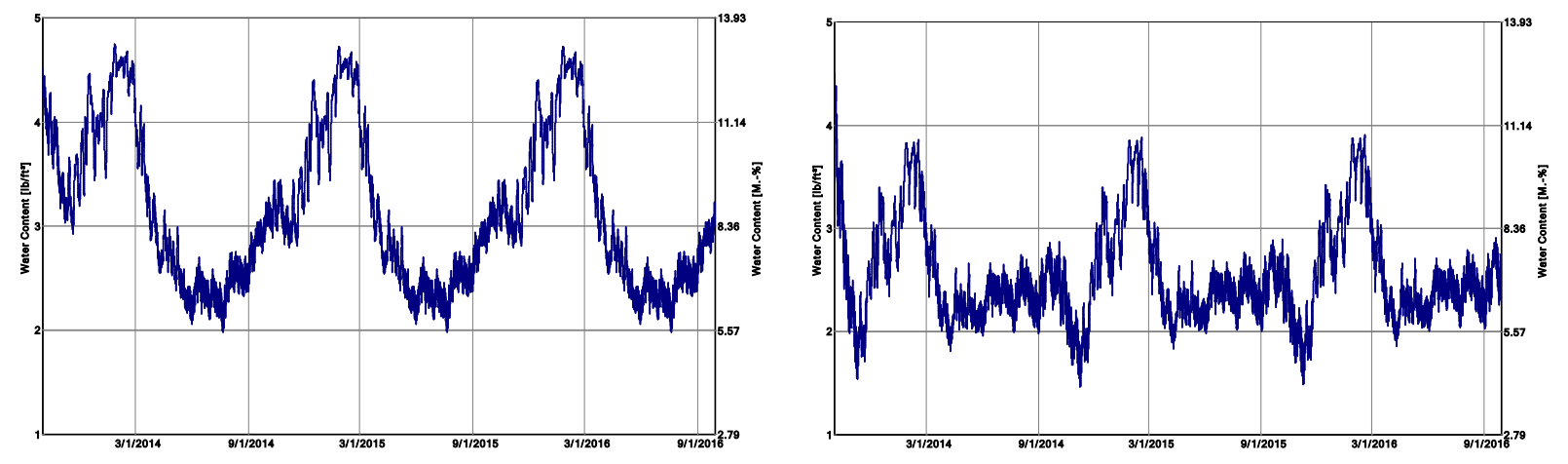

Figure 64. Round 2, Wall 3 sheathing MC in Houston (Zone 2A), north (left) and south (right)
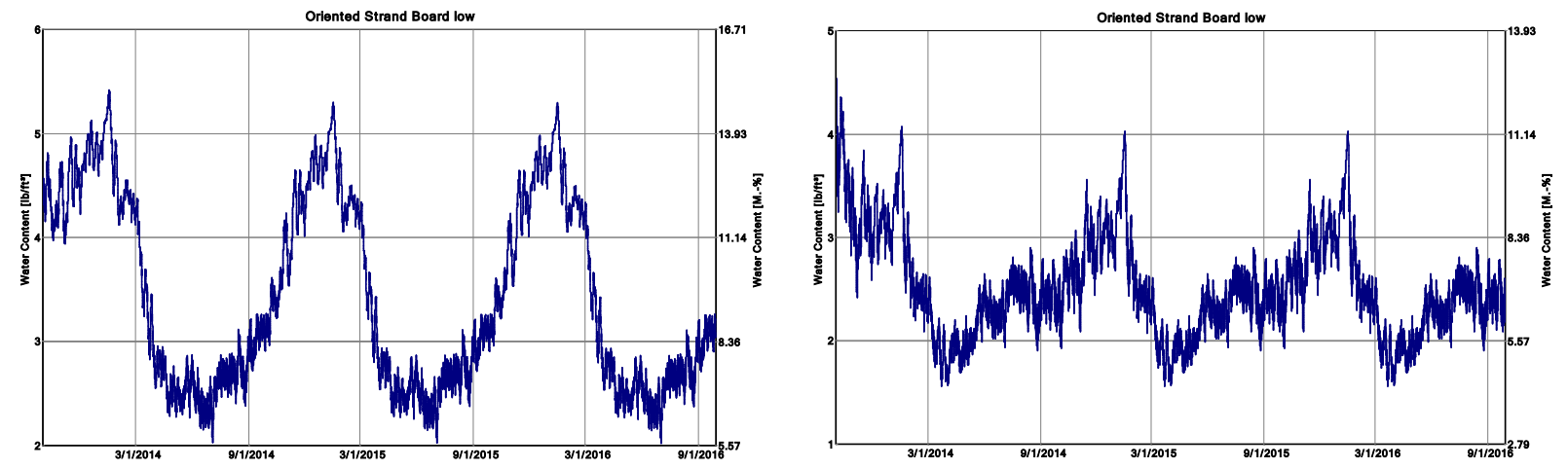

Figure 65. Round 2, Wall 3 sheathing MC in Atlanta (Zone 3A), north (left) and south (right) 

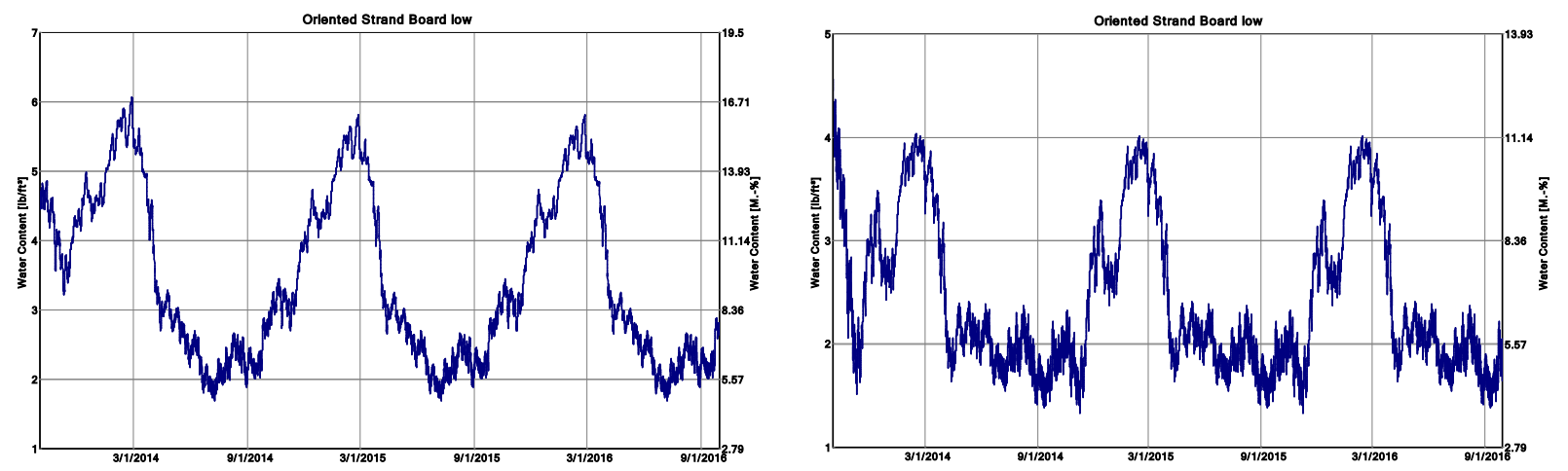

Figure 66. Round 2, Wall 3 sheathing MC in Kansas City (Zone 4A), north (left) and south (right)
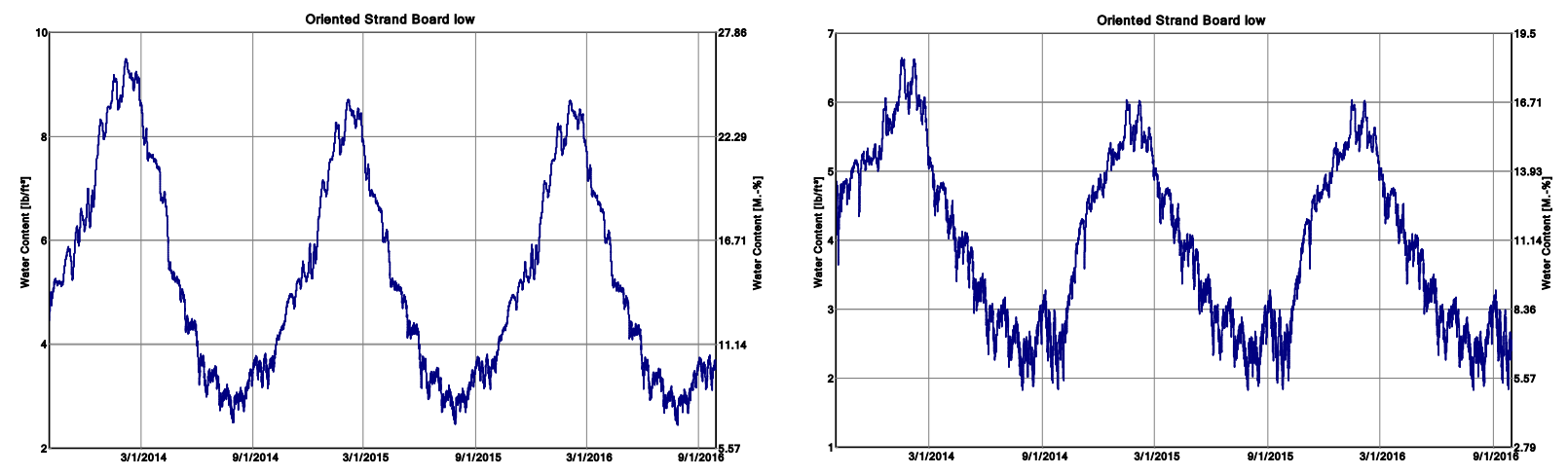

Figure 67. Round 2, Wall 3 sheathing MC in Seattle (Zone 4C), north (left) and south (right)
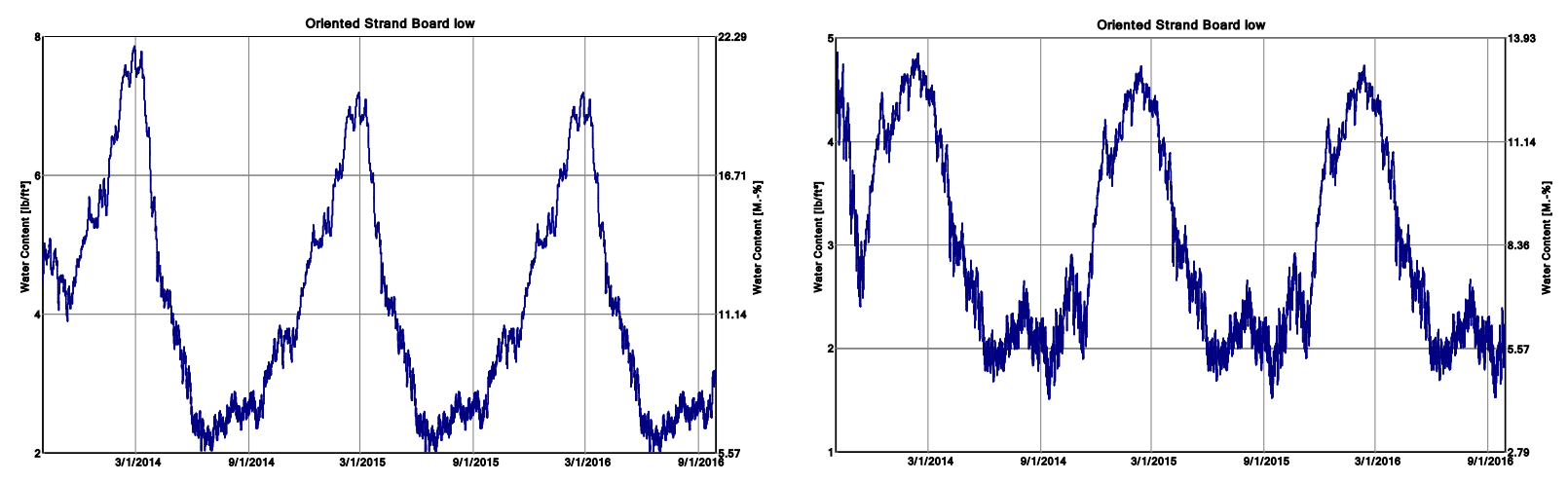

Figure 68. Round 2, Wall 3 sheathing MC in Chicago (Zone 5A), north (left) and south (right) 

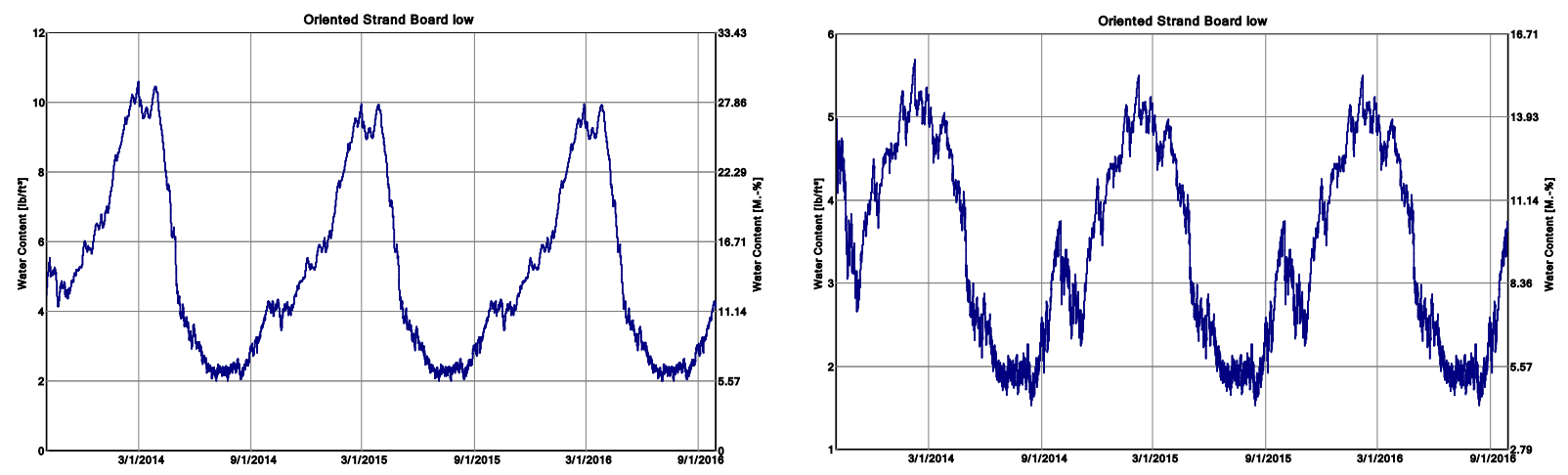

Figure 69. Round 2, Wall 3 sheathing MC in Minneapolis (Zone 6A), north (left) and south (right)

\subsubsection{Wall 4 (Brick-OSB)}

Table 16 describes the layers and their respective functions in the Round 2, Wall 4 configuration, and Figure 70 shows the layers from exterior to interior.

Table 16. Round 2, Wall 4 (Brick-OSB) layers

\begin{tabular}{ll}
\hline Layer & Function \\
\hline Brick veneer & provides exterior finish for aesthetics \\
\hline Asphalt saturated Kraft paper (building paper) & functions as air and water control layer \\
\hline OSB sheathing & provides structural support \\
\hline $\mathbf{2 x 6}$ framing & provides structural support \\
\hline Kraft-faced R-19 fiberglass batt & functions as thermal and vapor control layer \\
\hline Gypsum wall board & provides interior finish \\
\hline Latex paint & functions as vapor drive throttle \\
\hline
\end{tabular}




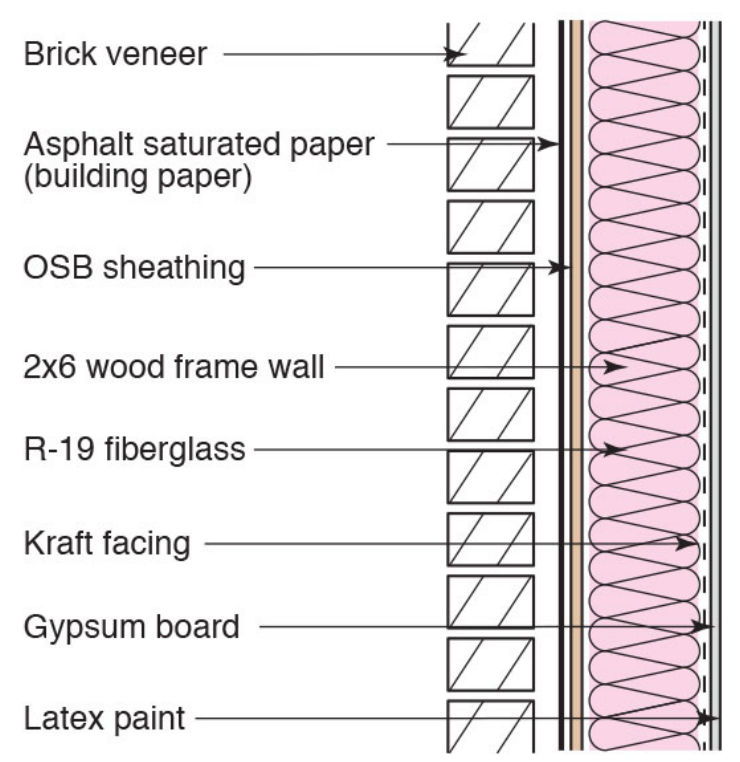

Figure 70. Round 2, Wall 4 (Brick-OSB) configuration

WUFI simulations are run on this wall on both north and south orientations in six climate zones; Figure 71 to Figure 76 show the MC graphs of the inner face of wall sheathing over a period of 3 years.
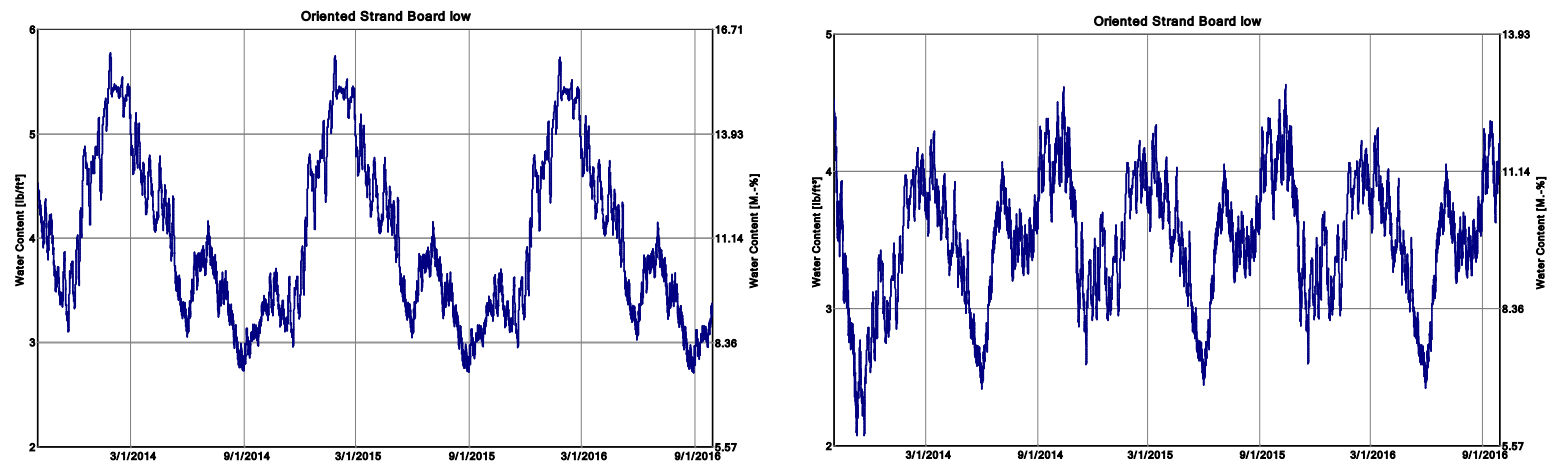

Figure 71. Round 2, Wall 4 sheathing MC in Houston (Zone 2A), north (left) and south (right)
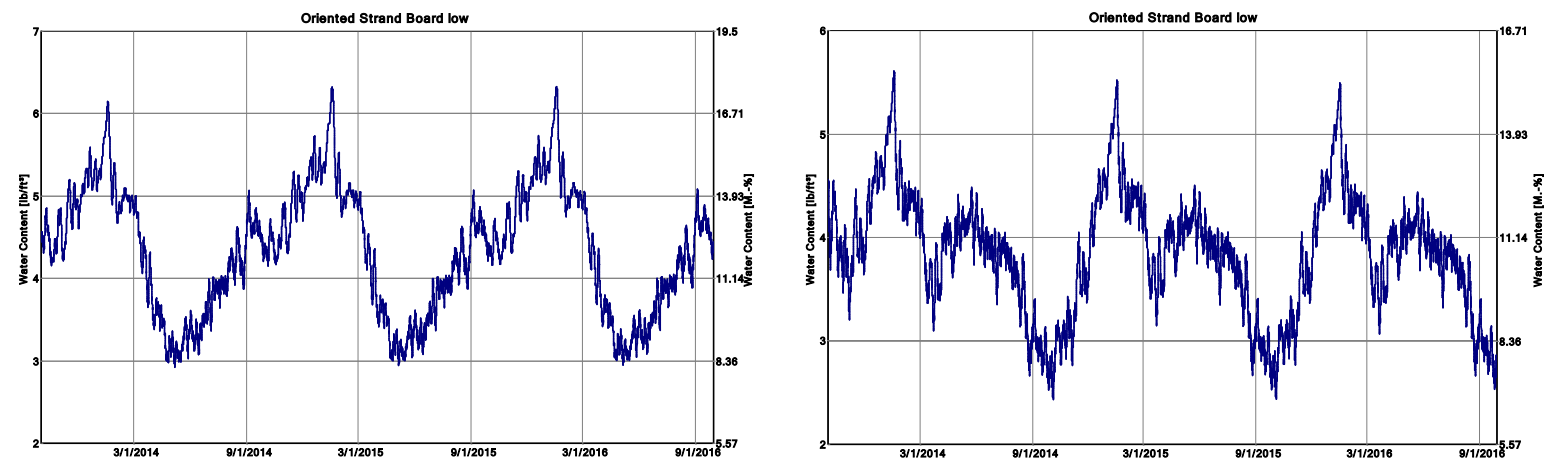

Figure 72. Round 2, Wall 4 sheathing MC in Atlanta (Zone 3A), north (left) and south (right) 

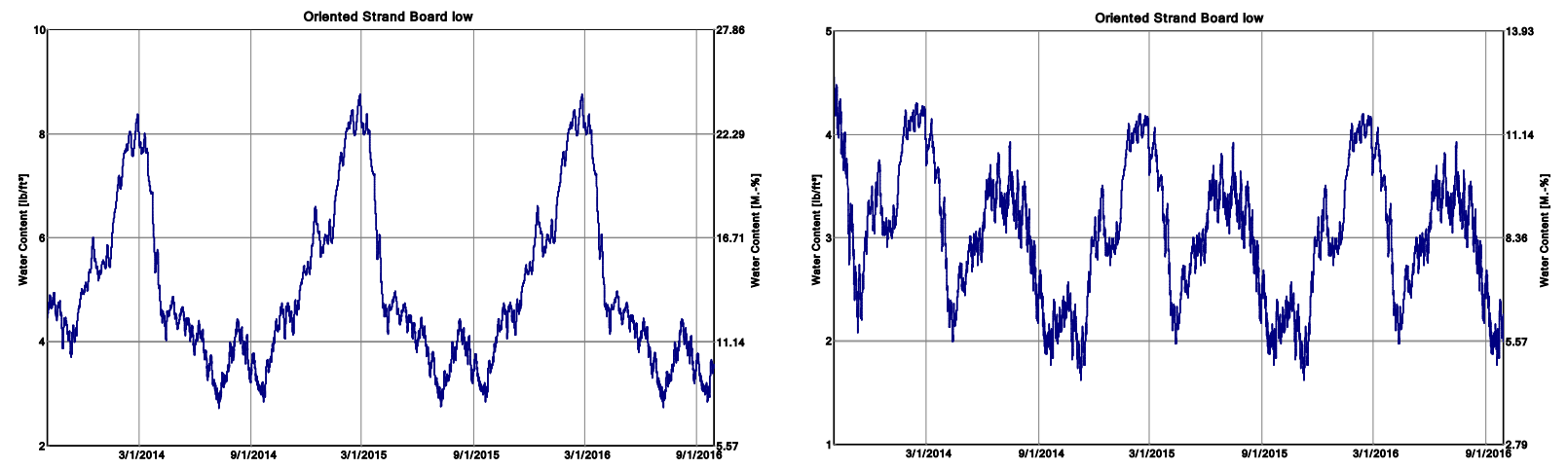

Figure 73. Round 2, Wall 4 sheathing MC in Kansas City (Zone 4A), north (left) and south (right)
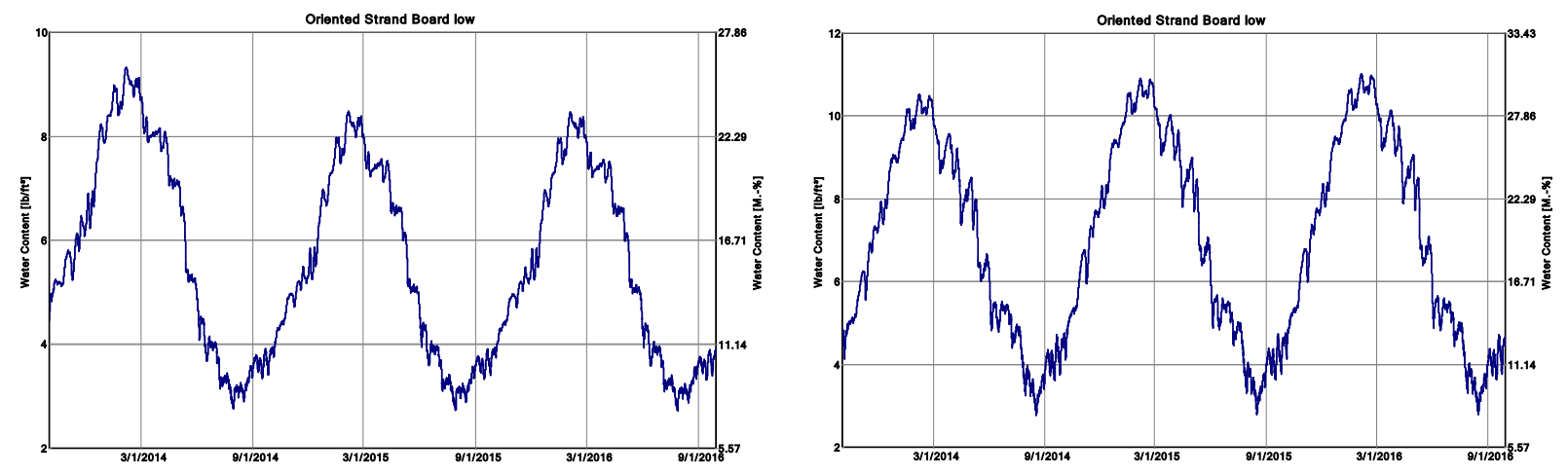

Figure 74. Round 2, Wall 4 sheathing MC in Seattle (Zone 4C), north (left) and south (right)
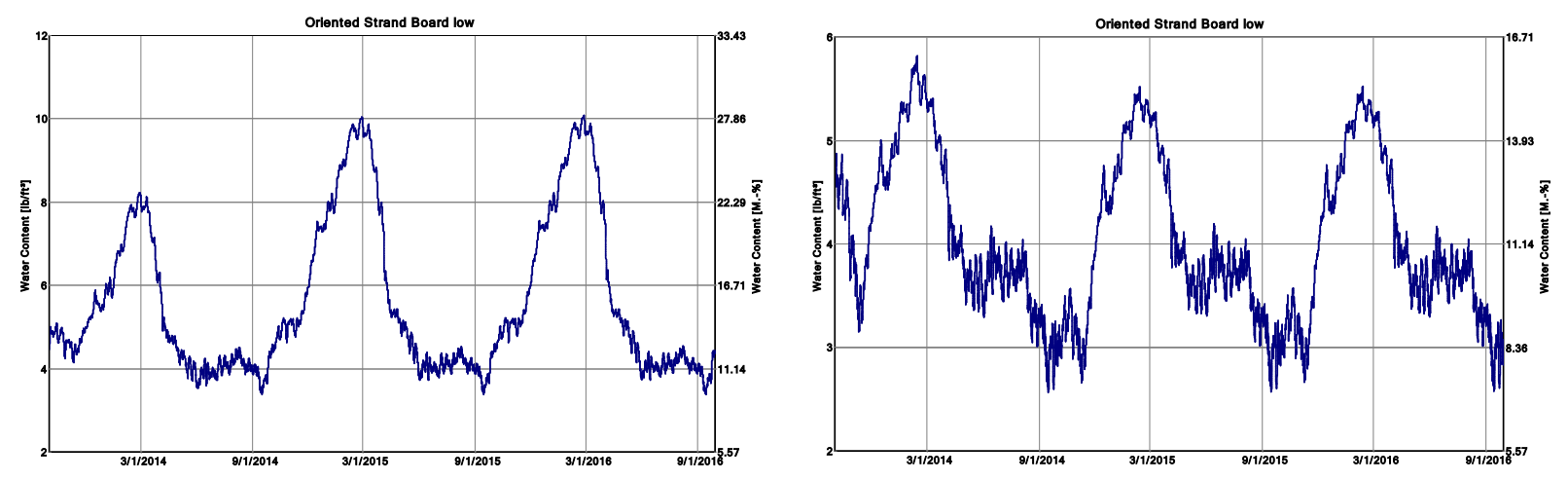

Figure 75. Round 2, Wall 4 sheathing MC in Chicago (Zone 5A), north (left) and south (right) 

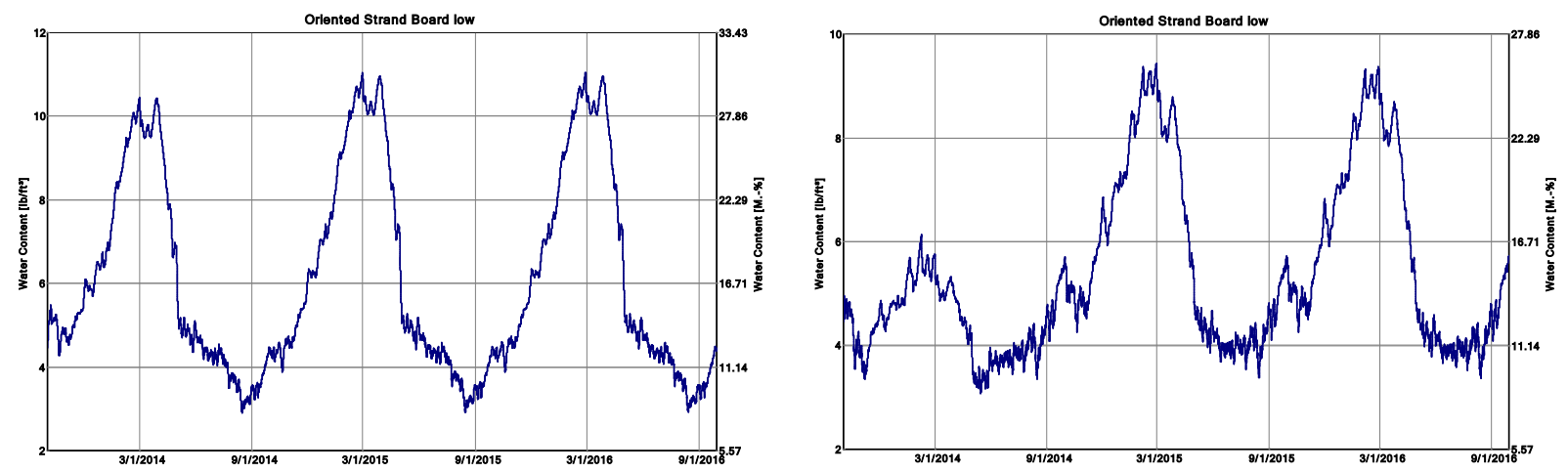

Figure 76. Round 2, Wall 4 sheathing MC in Minneapolis (Zone 6A), north (left) and south (right)

\subsubsection{Wall 5 (Stucco-OSB)}

Table 17 describes the layers and their respective functions in the Round 2, Wall 5 configuration, and Figure 77 shows the layers from exterior to interior.

Table 17. Round 2, Wall 5 (Stucco-OSB) Layers

\begin{tabular}{ll}
\hline Layer & Function \\
\hline Stucco & provides exterior finish for aesthetics \\
\hline $\begin{array}{l}\text { 2 layers asphalt saturated Kraft paper } \\
\text { (building paper) }\end{array}$ & functions as air and water control layer \\
\hline OSB sheathing & provides structural support \\
\hline 2x6 framing & provides structural support \\
\hline Kraft-faced R-19 fiberglass batt & functions as thermal and vapor control layer \\
\hline Gypsum wall board & provides interior finish \\
\hline Latex paint & functions as vapor drive throttle \\
\hline
\end{tabular}




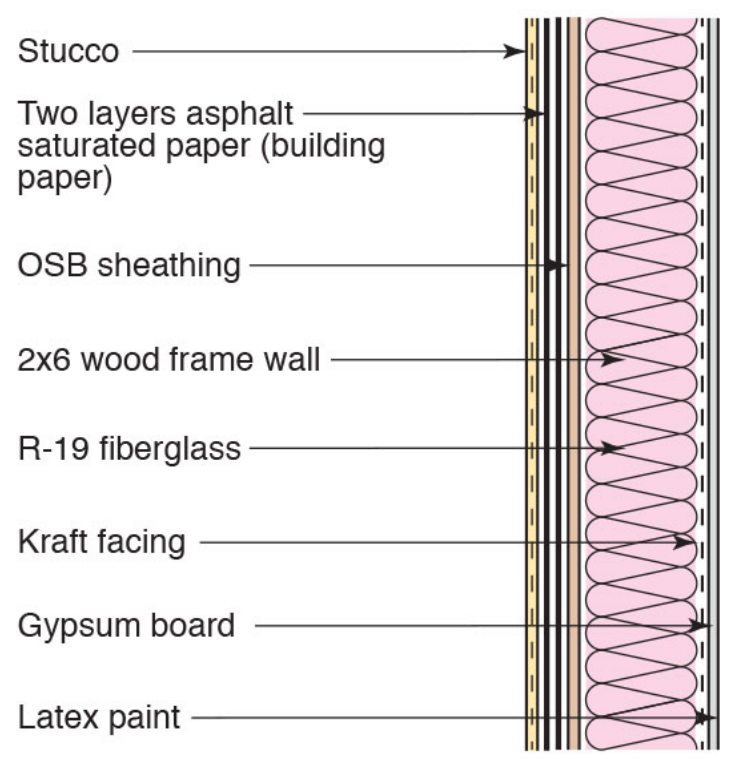

Figure 77. Round 2, Wall 5 (Stucco-OSB) configuration

WUFI simulations are run on this wall on both north and south orientations in six climate zones; Figure 78 to Figure 83 show the MC graphs of the inner face of wall sheathing over a period of 3 years.
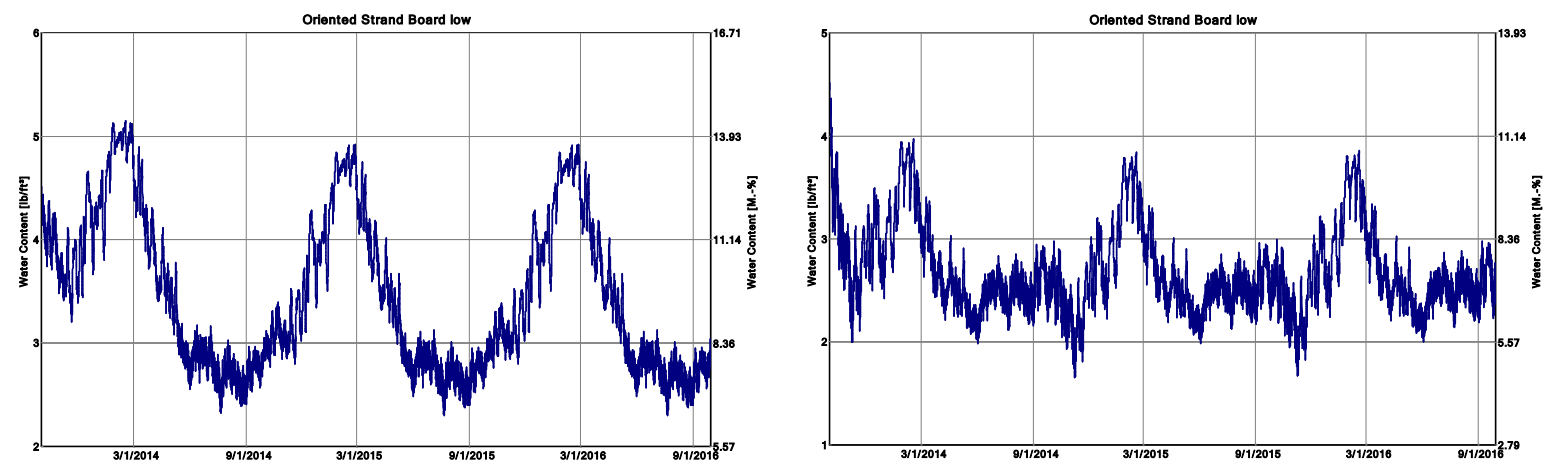

Figure 78. Round 2, Wall 5 sheathing MC in Houston (Zone 2A), north (left) and south (right)
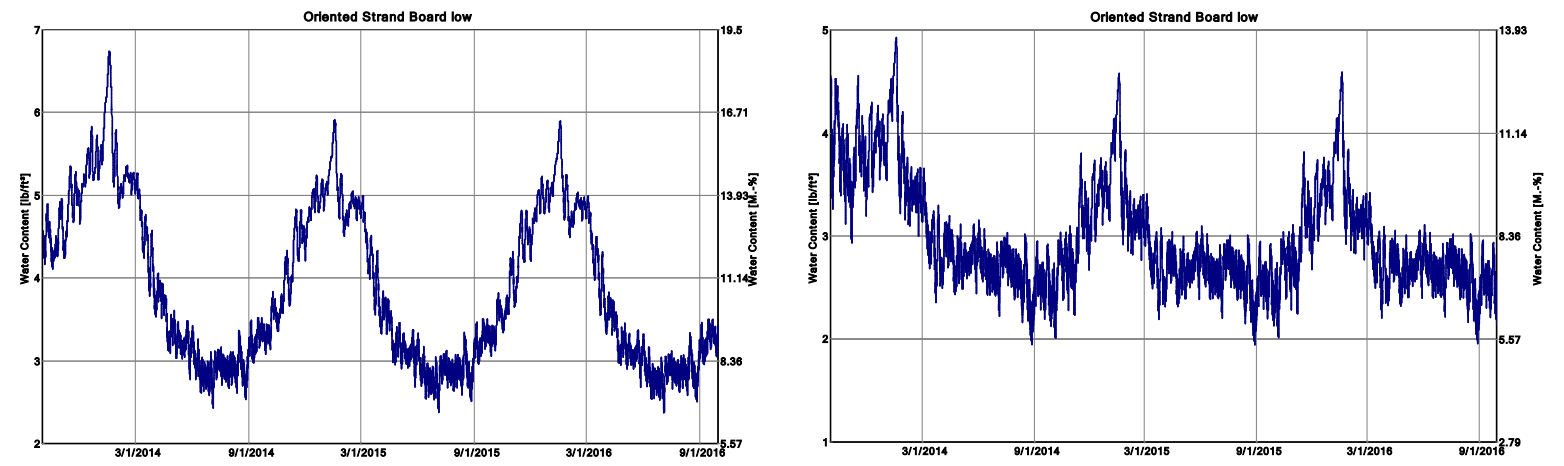

Figure 79. Round 2, Wall 5 sheathing MC in Atlanta (Zone 3A), north (left) and south (right) 

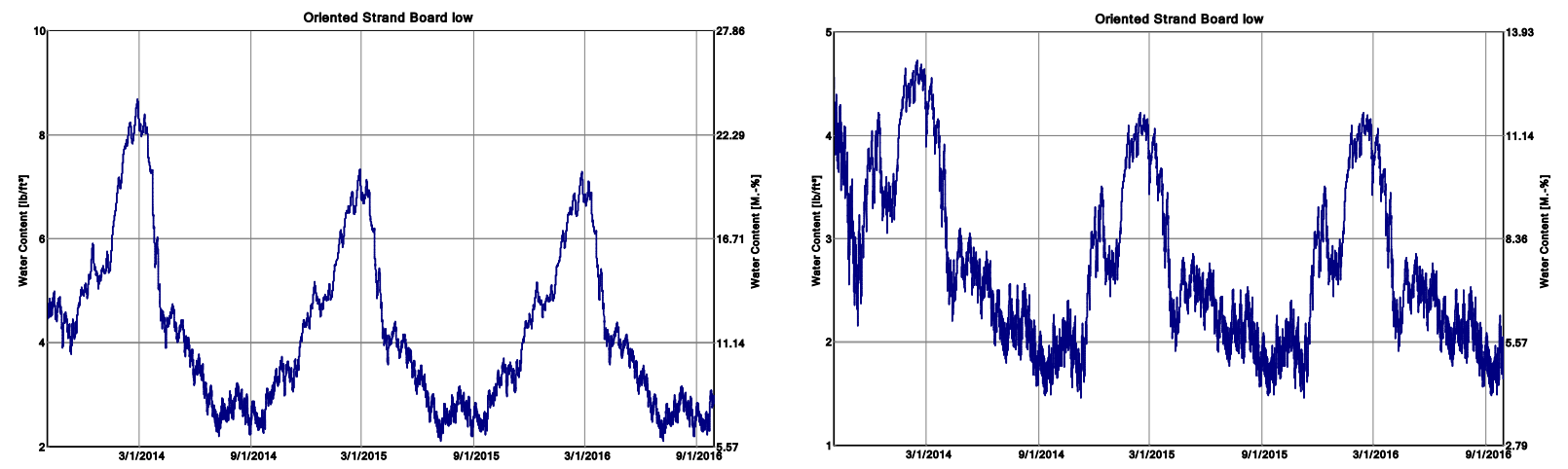

Figure 80. Round 2, Wall 5 sheathing MC in Kansas City (Zone 4A), north (left) and south (right)
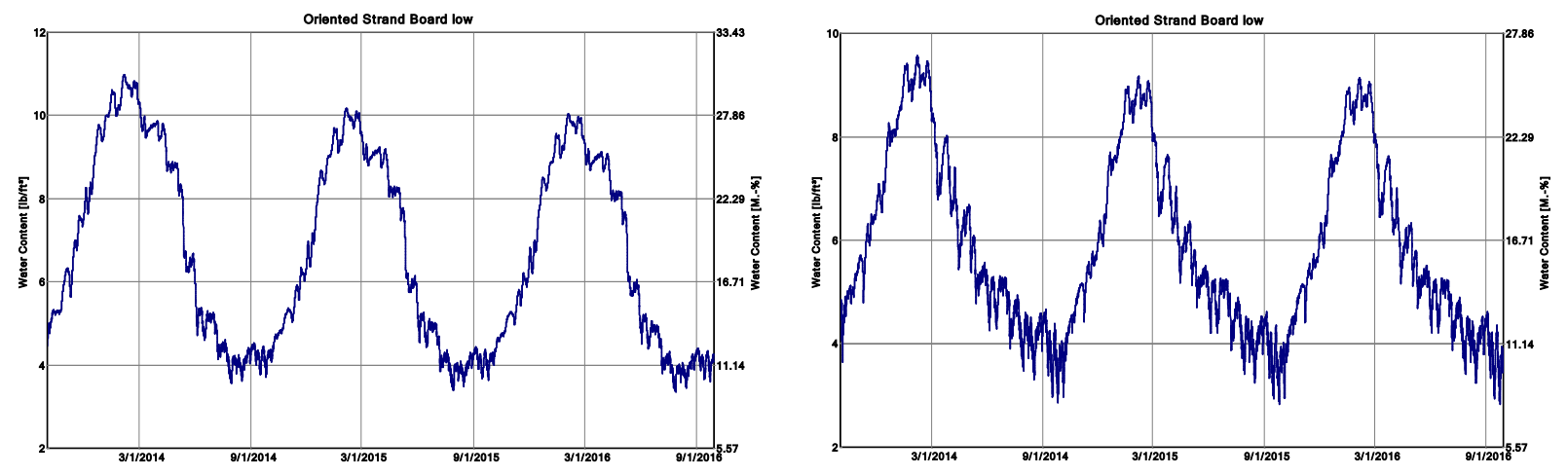

Figure 81. Round 2, Wall 5 sheathing MC in Seattle (Zone 4C), north (left) and south (right)
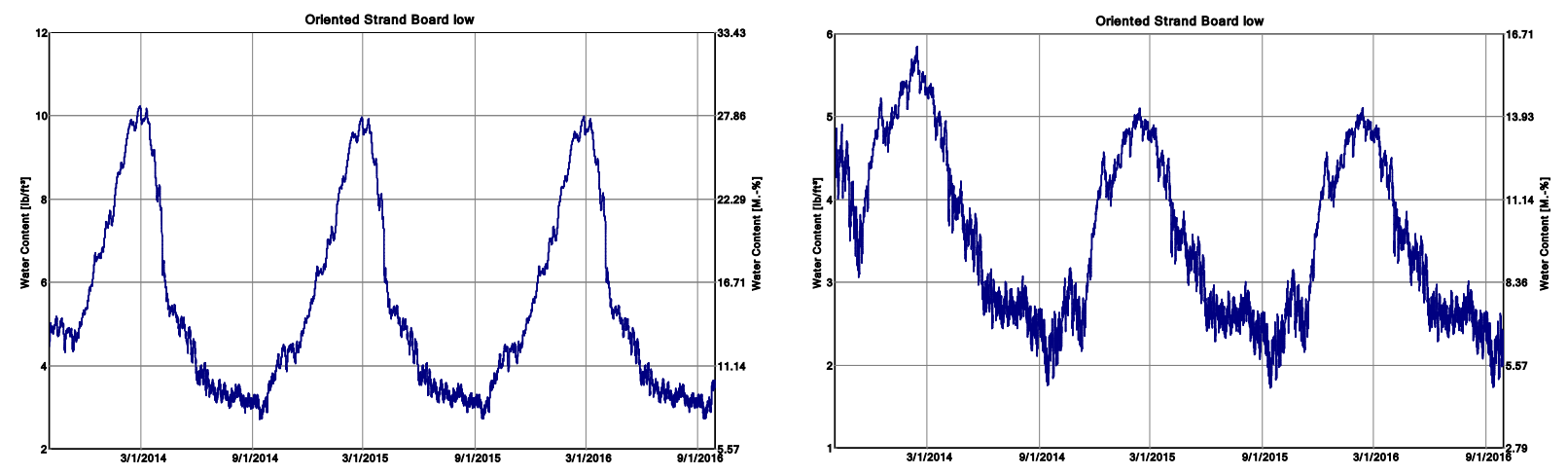

Figure 82. Round 2, Wall 5 sheathing MC in Chicago (Zone 5A), north (left) and south (right) 

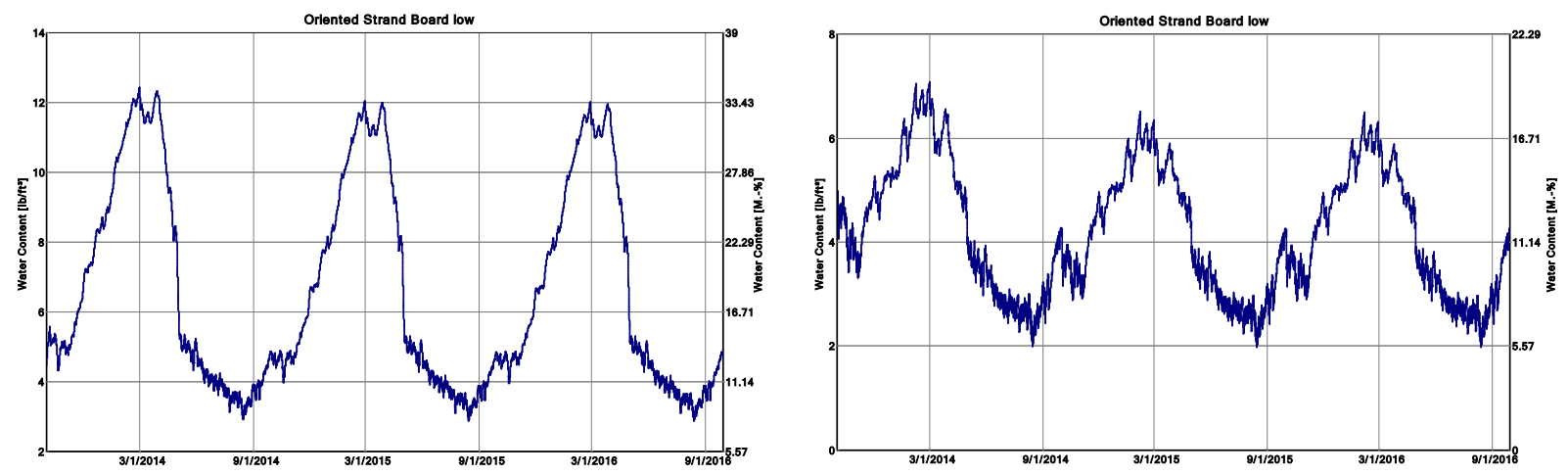

Figure 83. Round 2, Wall 5 sheathing MC in Minneapolis (Zone 6A), north (left) and south (right)

\subsubsection{Wall 6 (Vented Stucco-OSB)}

Table 18 describes the layers and their respective functions in the Round 2, Wall 6 configuration, and Figure 84 shows the layers from exterior to interior.

Table 18. Round 2, Wall 6 (Vented Stucco-OSB) layers

\begin{tabular}{ll}
\hline Layer & Function \\
\hline Stucco & provides exterior finish for aesthetics \\
\hline $\begin{array}{l}1 \text { layer asphalt saturated Kraft paper } \\
\text { (building paper) }\end{array}$ & provides backing for stucco \\
\hline Polypropylene drainage mat $(\mathbf{1} / \mathbf{2}$ in.) & provides drainage and ventilation gap \\
\hline $\begin{array}{l}\text { Another layer asphalt saturated Kraft paper } \\
\text { (building paper) }\end{array}$ & functions as air and water control layer \\
\hline $\begin{array}{l}\text { OSB sheathing } \\
\text { 2x6 framing }\end{array}$ & provides structural support \\
\hline Kraft-faced $\mathbf{R}-19$ fiberglass batt & provides structural support \\
\hline Gypsum wall board & functions as thermal and vapor control layer \\
\hline Latex paint & provides interior finish \\
\hline
\end{tabular}




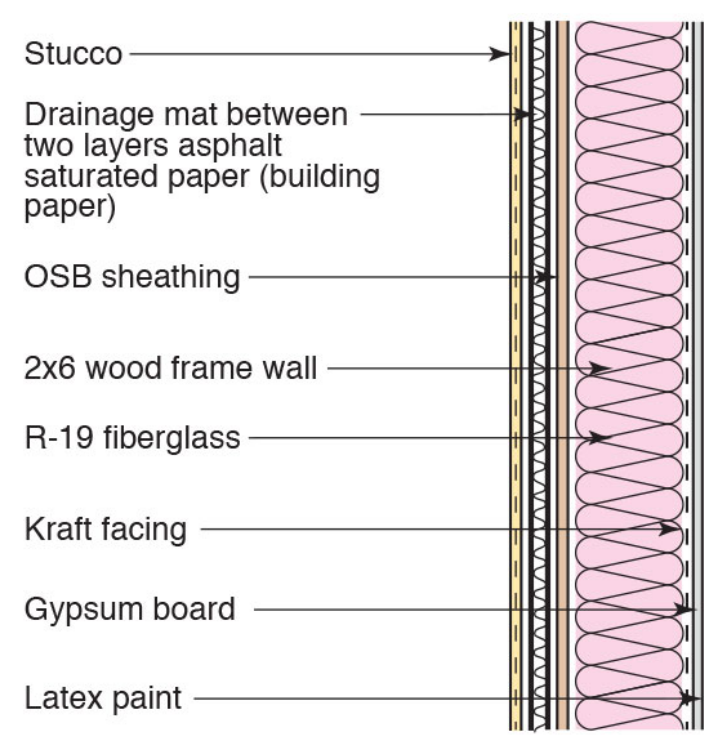

Figure 84. Round 2, Wall 6 (Vented Stucco-OSB) configuration

WUFI simulations are run on this wall on both north and south orientations in six climate zones; Figure 85 to Figure 90 show the MC graphs of the inner face of wall sheathing over a period of 3 years.
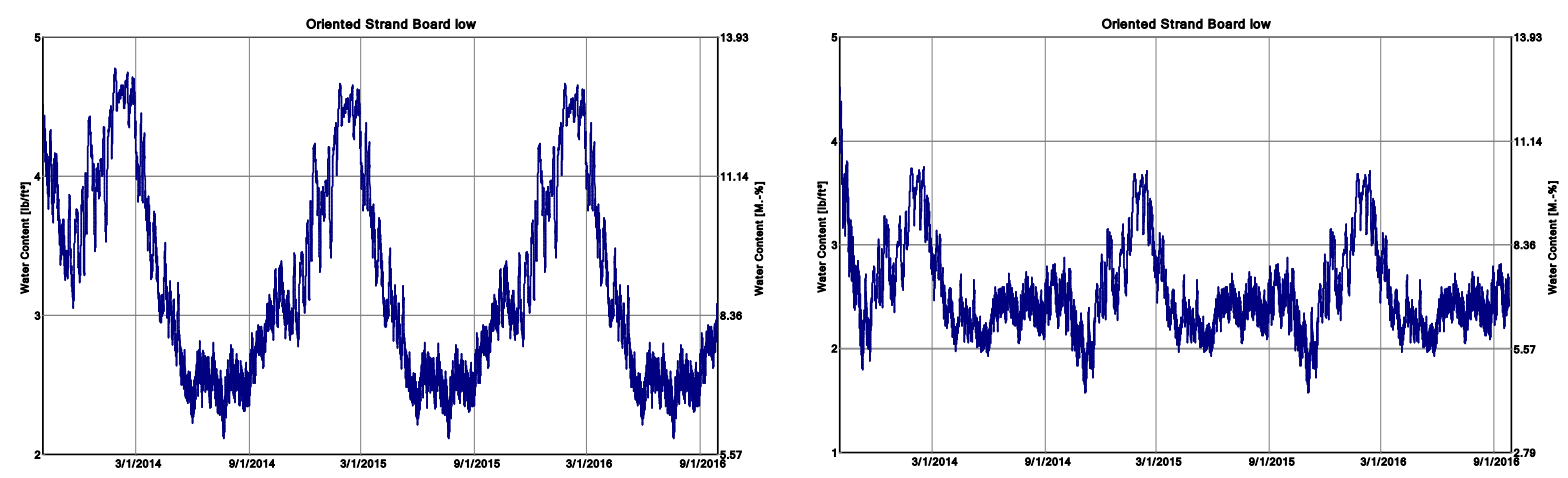

Figure 85. Round 2, Wall 6 sheathing MC in Houston (Zone 2A), north (left) and south (right)
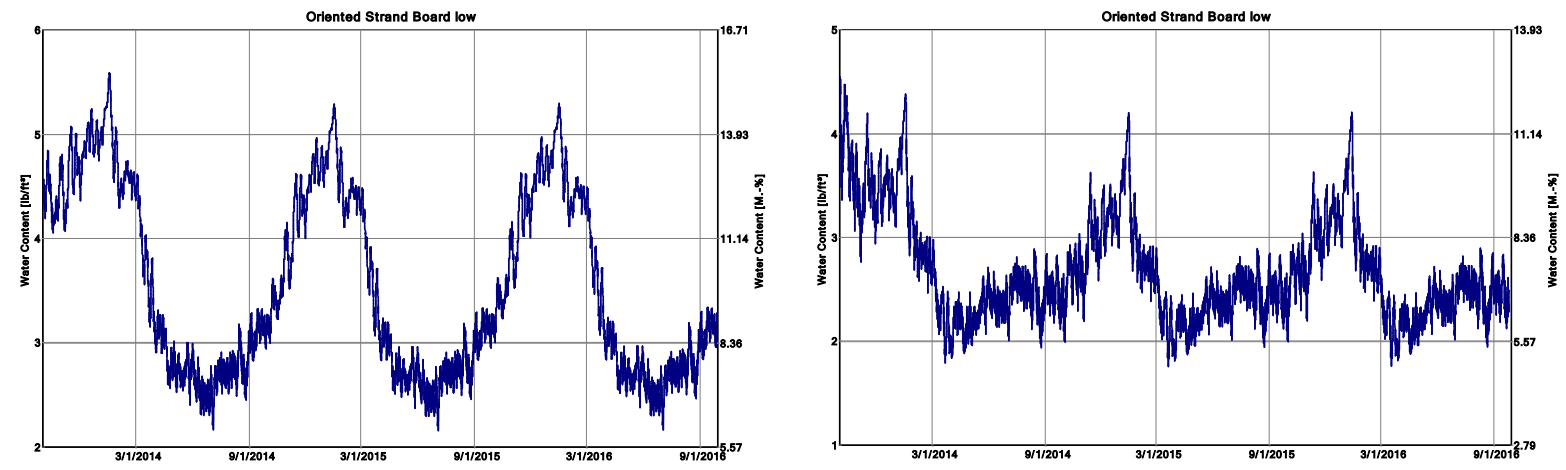

Figure 86. Round 2, Wall 6 sheathing MC in Atlanta (Zone 3A), north (left) and south (right) 

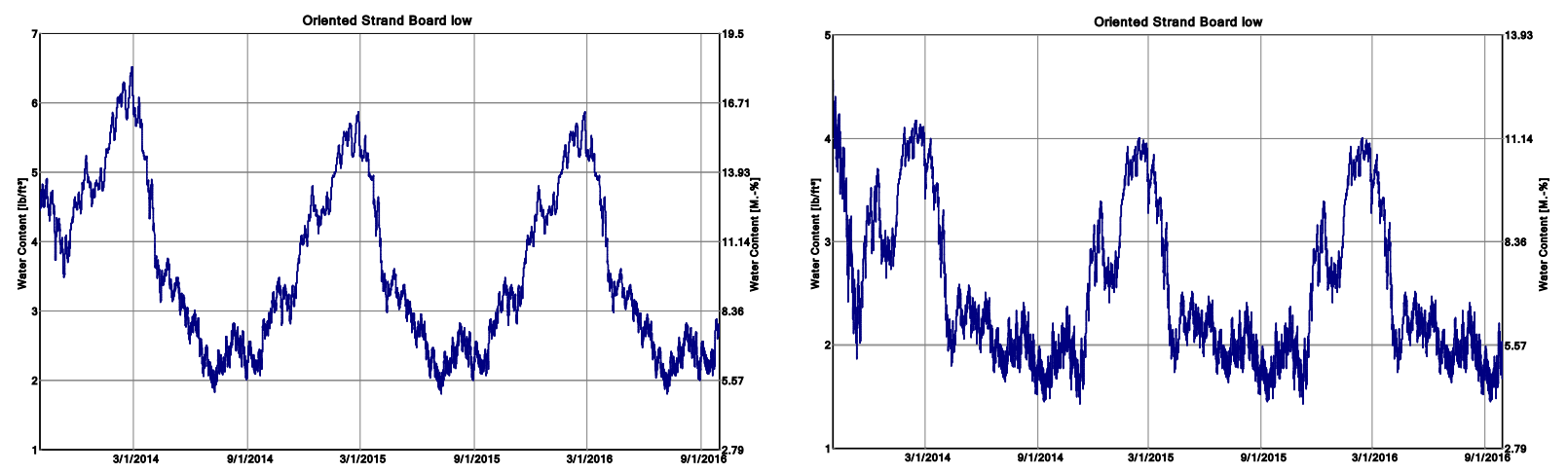

Figure 87. Round 2, Wall 6 sheathing MC in Kansas City (Zone 4A), north (left) and south (right)
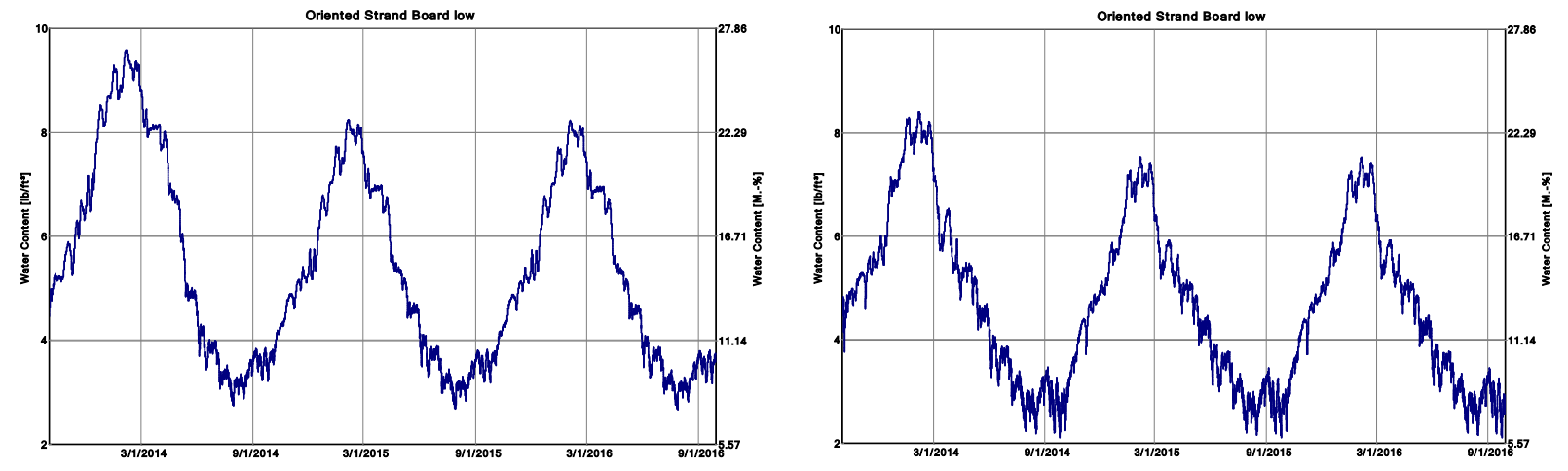

Figure 88. Round 2, Wall 6 sheathing MC in Seattle (Zone 4C), north (left) and south (right)
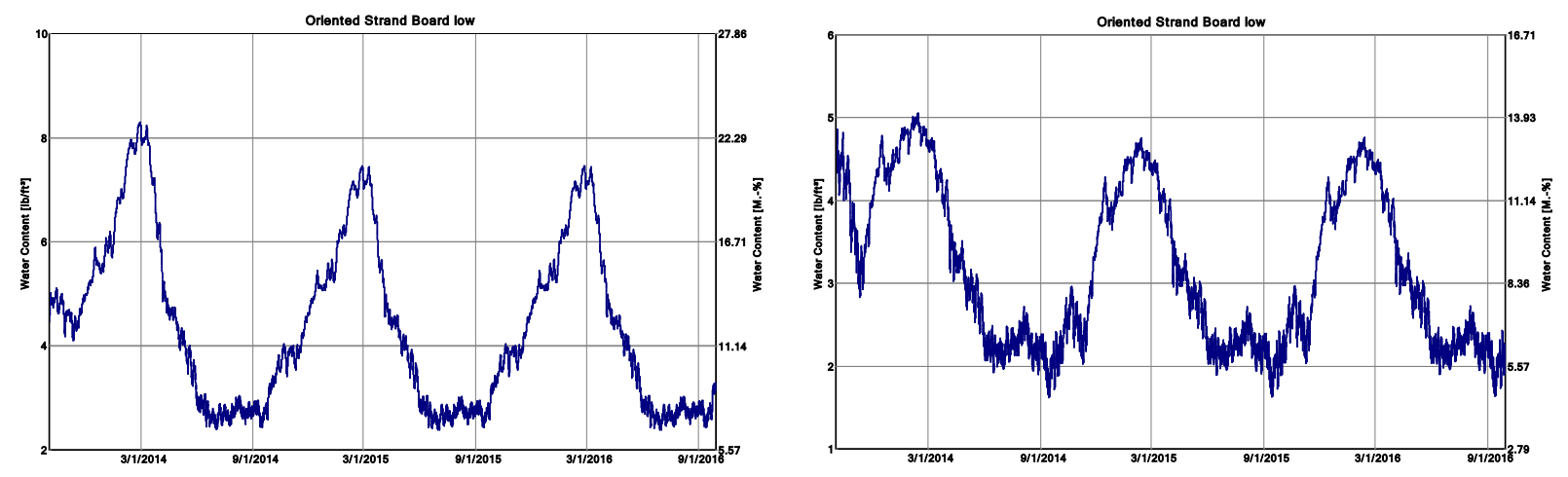

Figure 89. Round 2, Wall 6 sheathing MC in Chicago (Zone 5A), north (left) and south (right) 

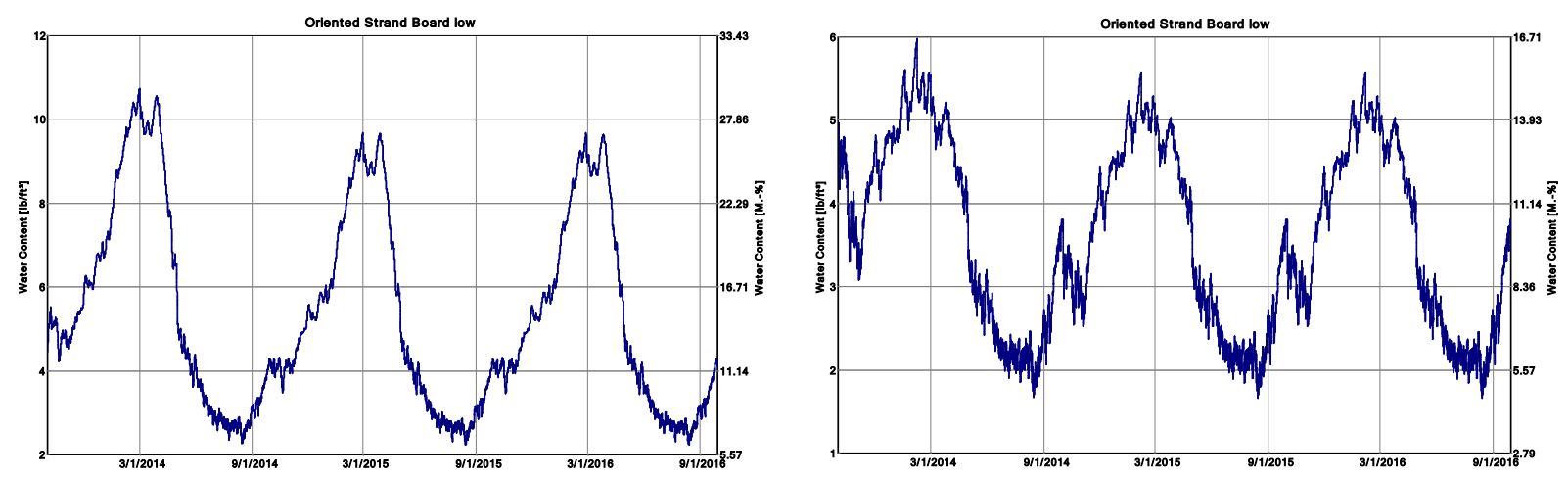

Figure 90. Round 2, Wall 6 sheathing MC in Minneapolis (Zone 6A), north (left) and south (right)

\subsection{Round 3 (2x6 Framing, R-13 Fiberglass, Kraft Facing $\rightarrow$ Polyethylene)}

In the third round, the Round 2 walls are redone replacing Kraft facing with 6-mil polyethylene.

\subsubsection{Wall 1 (Wood Siding-Ply)}

Table 19 describes the layers and their respective functions in the Round 3, Wall 1 configuration, and Figure 91 shows the layers from exterior to interior.

Table 19. Round 3, Wall 1 (Wood Siding-Ply) Layers

\begin{tabular}{ll}
\hline Layer & Function \\
\hline Latex painted wood siding & provides exterior finish for aesthetics \\
\hline Asphalt saturated Kraft paper (building paper) & functions as air and water control layer \\
\hline Plywood sheathing & provides structural support \\
\hline $\mathbf{2 \times 6}$ framing & provides structural support \\
\hline R-19 fiberglass batt & functions as thermal control layer \\
\hline 6-mil polyethylene & functions as vapor control layer \\
\hline Gypsum wall board & provides interior finish \\
\hline Latex paint & functions as vapor drive throttle \\
\hline
\end{tabular}




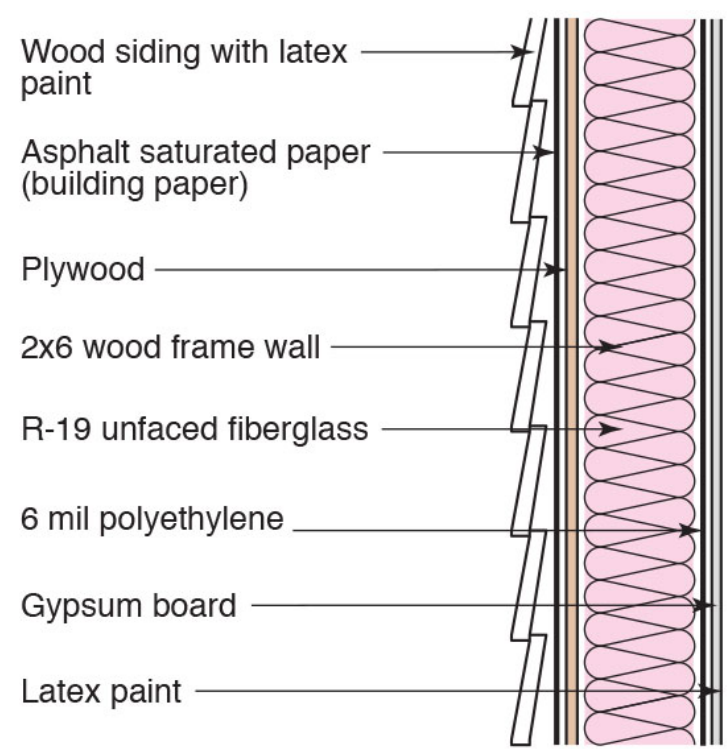

Figure 91. Round 3, Wall 1 (Wood Siding-Ply) configuration

WUFI simulations are run on this wall on both north and south orientations in six climate locations; Figure 92 to Figure 97 show the MC graphs of the inner face of wall sheathing over a period of 3 years.
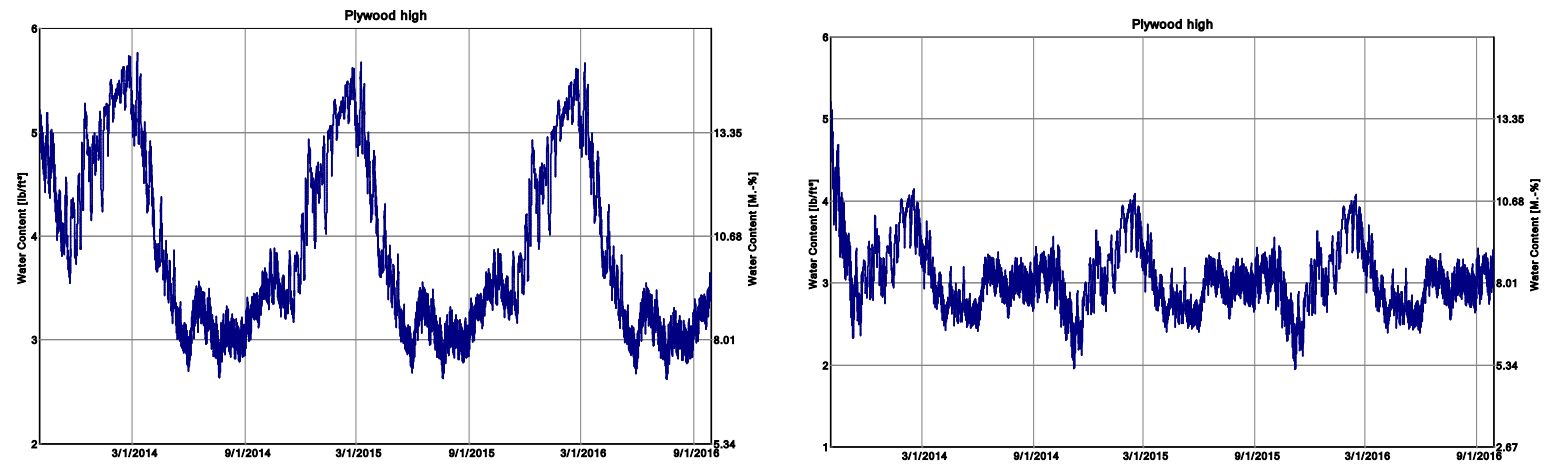

Figure 92. Round 3, Wall 1 sheathing MC in Houston (Zone 2A), north (left) and south (right)
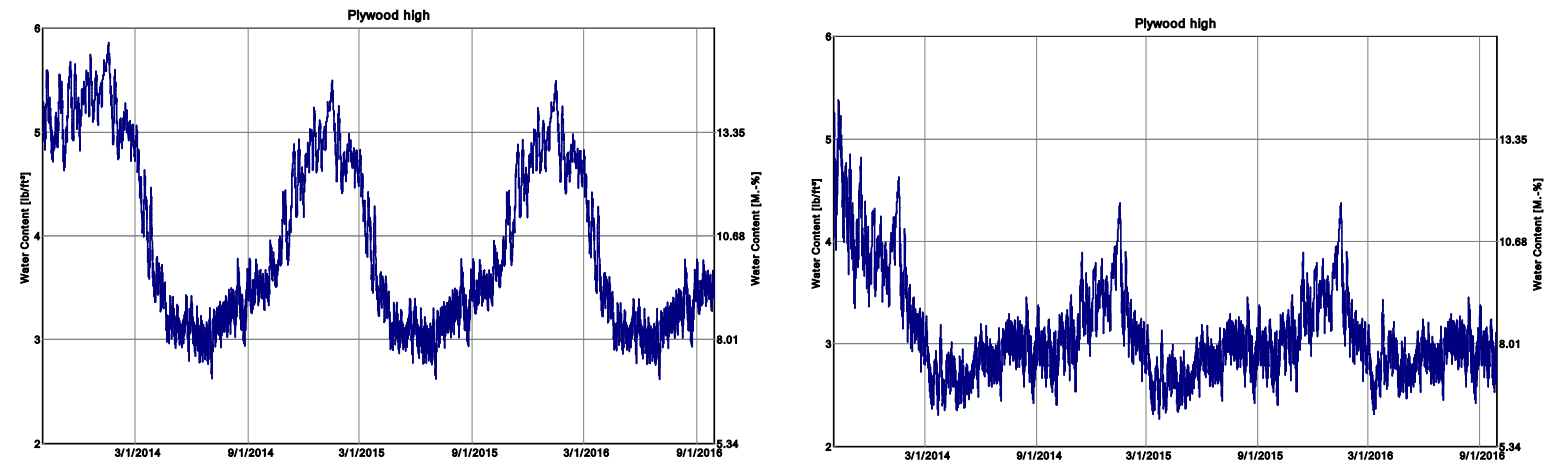

Figure 93. Round 3, Wall 1 sheathing MC in Atlanta (Zone 3A), north (left) and south (right) 

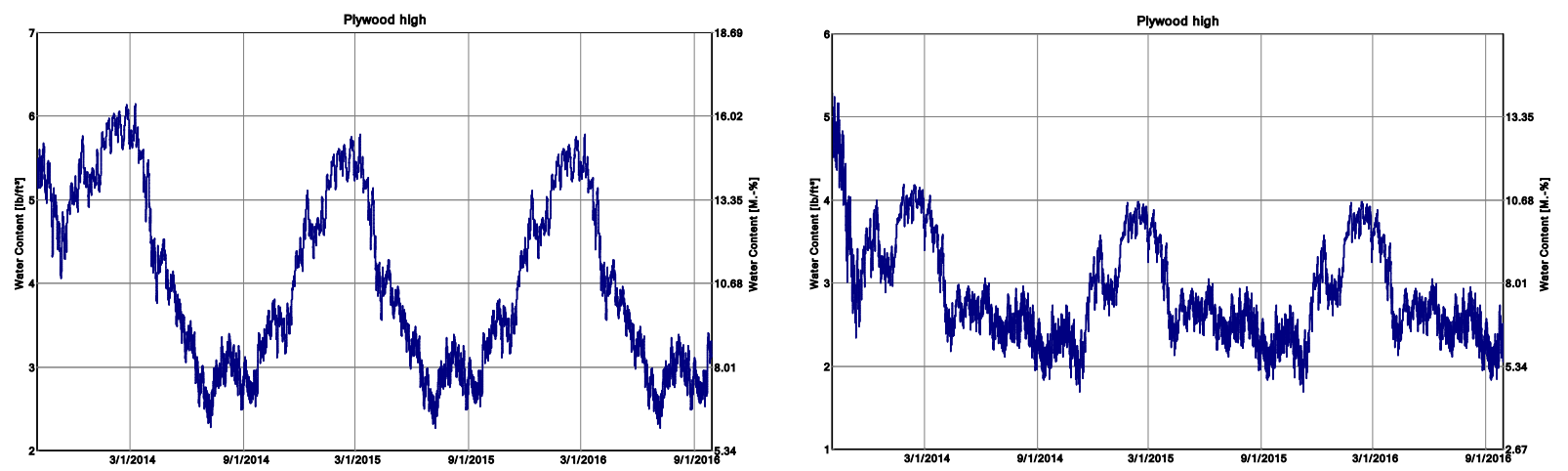

Figure 94. Round 3, Wall 1 sheathing MC in Kansas City (Zone 4A), north (left) and south (right)
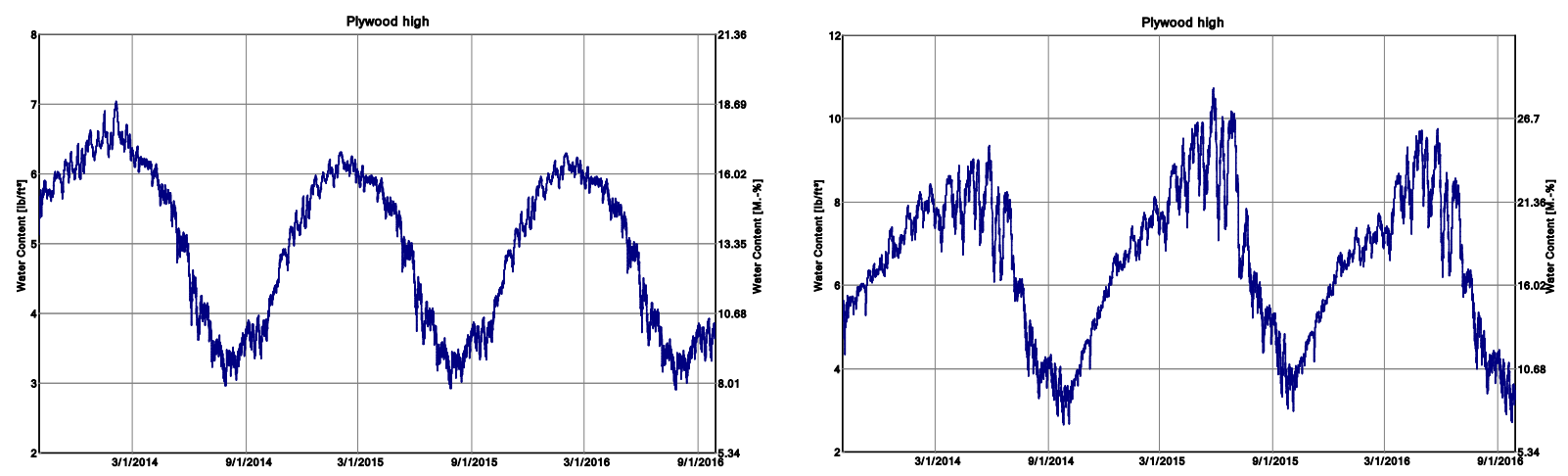

Figure 95. Round 3, Wall 1 sheathing MC in Seattle (Zone 4C), north (left) and south (right)
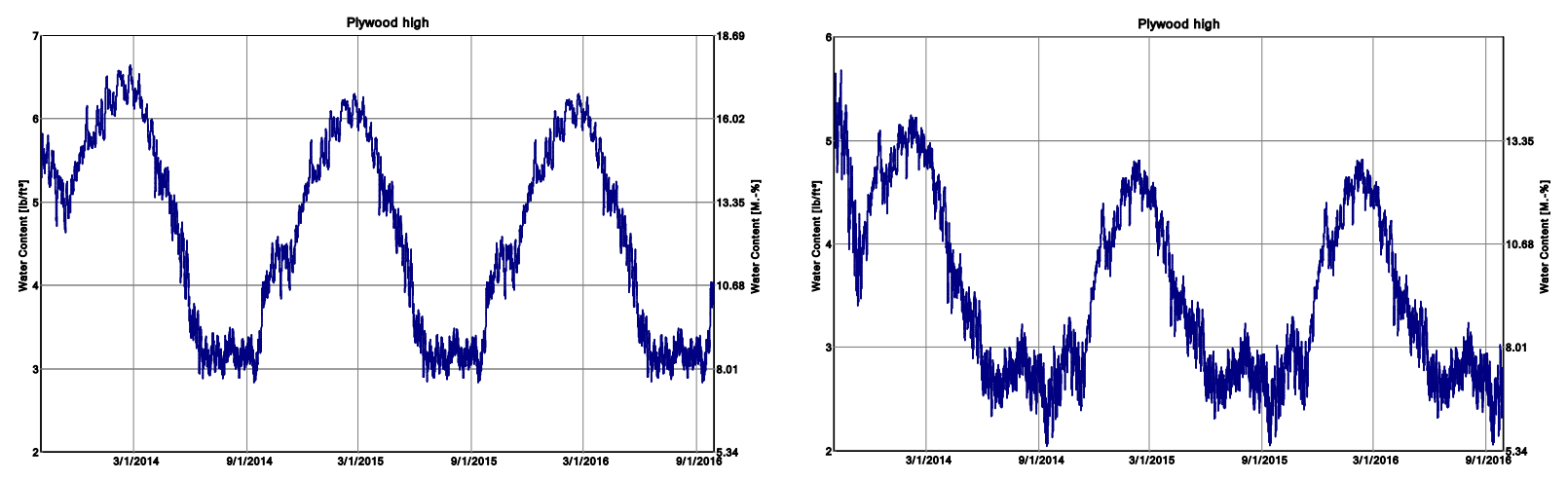

Figure 96. Round 3, Wall 1 sheathing MC in Chicago (Zone 5A), north (left) and south (right) 

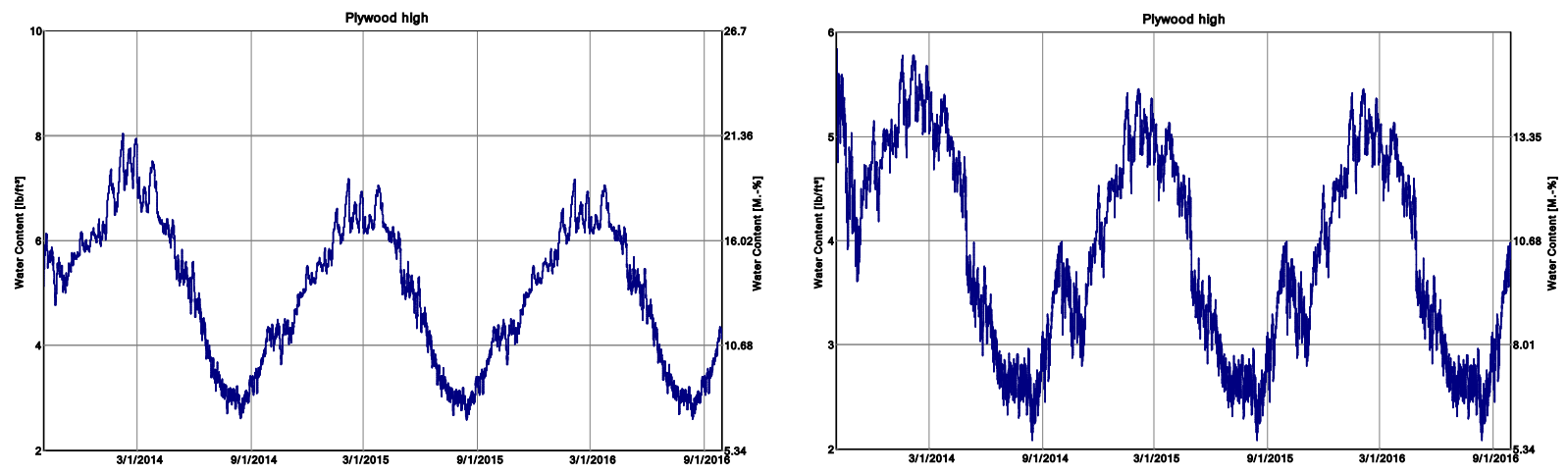

Figure 97. Round 3, Wall 1 sheathing MC in Minneapolis (Zone 6A), north (left) and south (right)

\subsubsection{Wall 2 (Vinyl Siding-Ply)}

Table 20 describes the layers and their respective functions in the Round 3, Wall 2 configuration, and Figure 98 shows the layers from exterior to interior.

Table 20. Round 3, Wall 2 (Vinyl Siding-Ply) layers

\begin{tabular}{ll}
\hline Layer & Function \\
\hline Vinyl siding & provides exterior finish for aesthetics \\
\hline Asphalt saturated Kraft paper (building paper) & functions as air and water control layer \\
\hline Plywood sheathing & provides structural support \\
\hline $\mathbf{2 x 6}$ framing & provides structural support \\
R-19 fiberglass batt & functions as thermal control layer \\
\hline 6-mil polyethylene & functions as vapor control layer \\
\hline Gypsum wall board & provides interior finish \\
\hline Latex paint & functions as vapor drive throttle \\
\hline
\end{tabular}




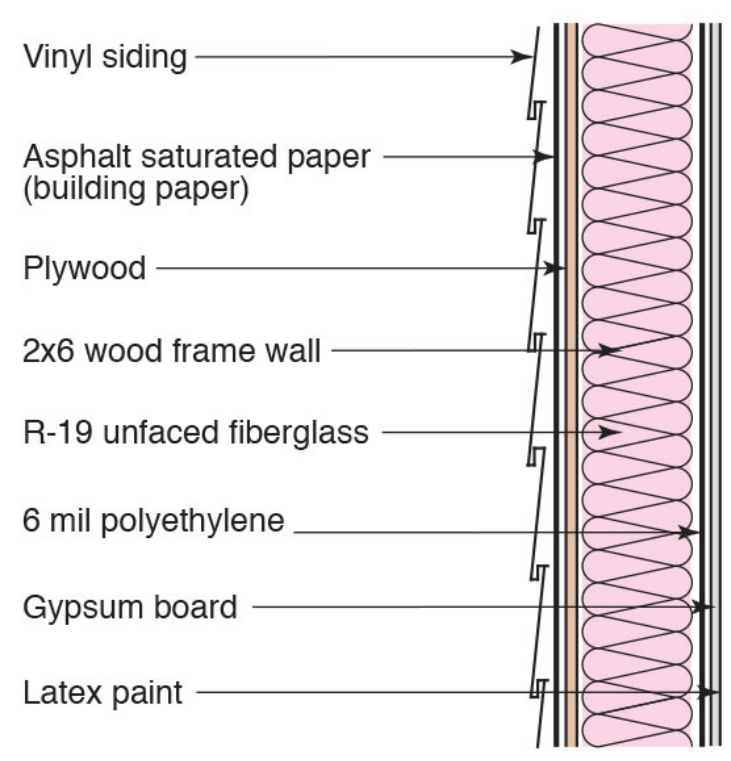

Figure 98. Round 3, Wall 2 (Vinyl Siding-Ply) configuration

WUFI simulations are run on this wall on both north and south orientations in six climate zones; Figure 99 to Figure 104 show the MC graphs of the inner face of wall sheathing over a period of 3 years.
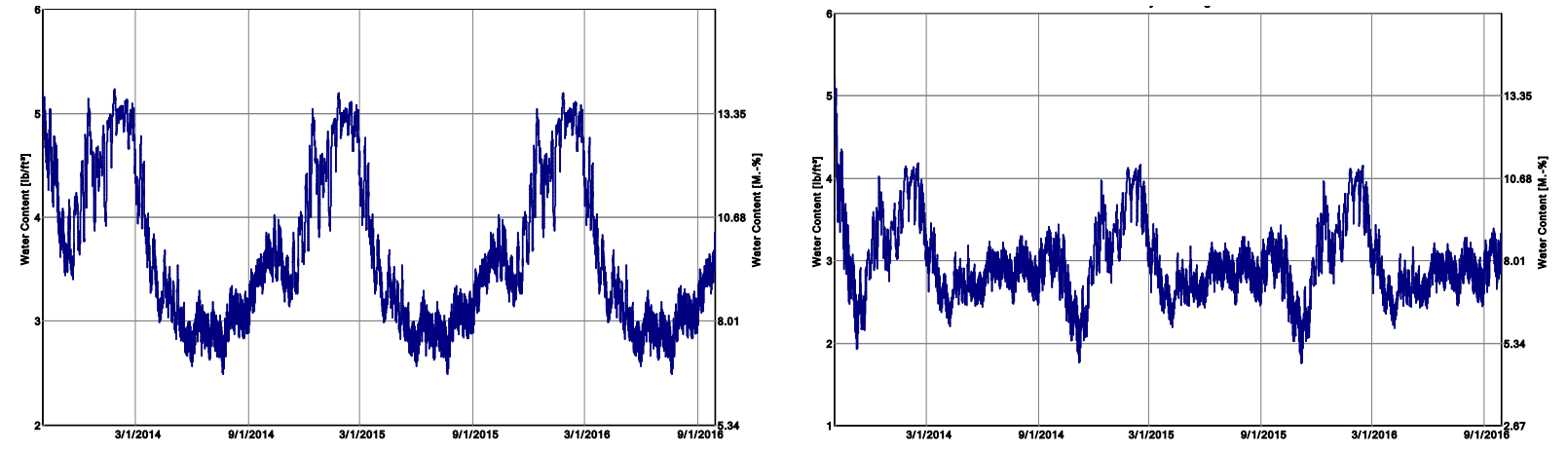

Figure 99. Round 3, Wall 2 sheathing MC in Houston (Zone 2A), north (left) and south (right)
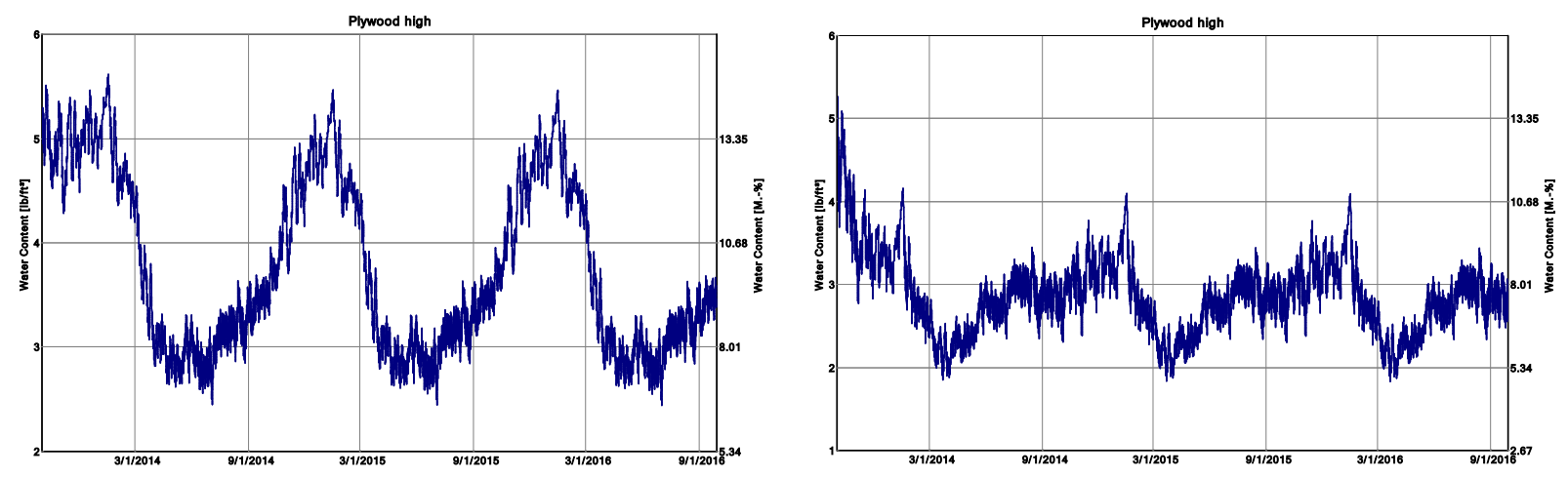

Figure 100. Round 3, Wall 2 sheathing MC in Atlanta (Zone 3A), north (left) and south (right) 

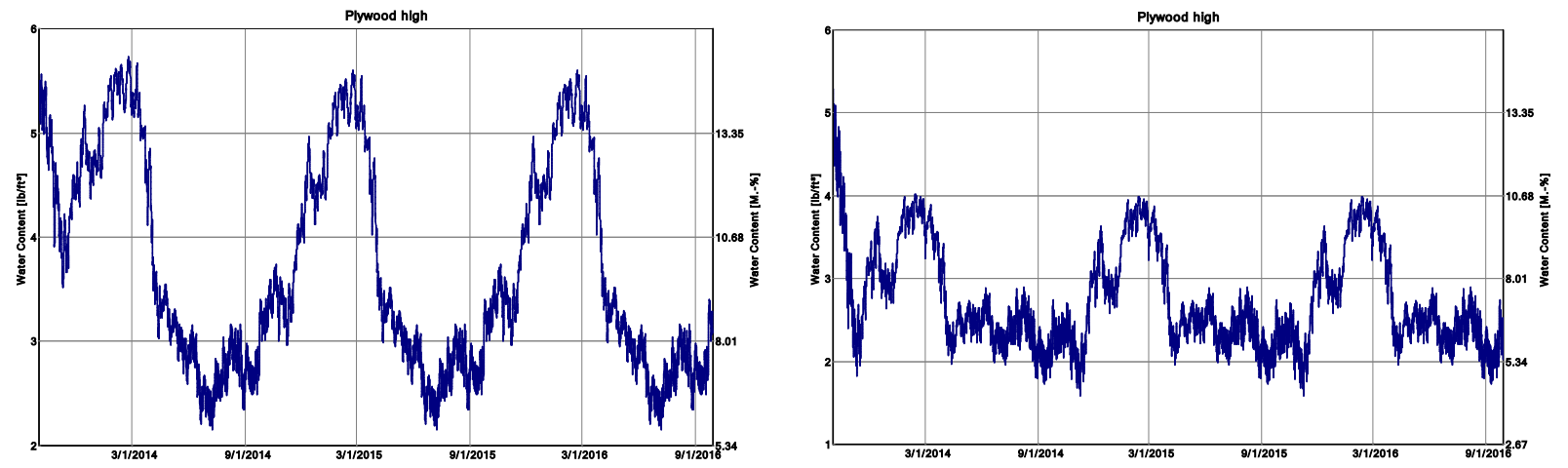

Figure 101. Round 3, Wall 2 sheathing MC in Kansas City (Zone 4A), north (left) and south (right)
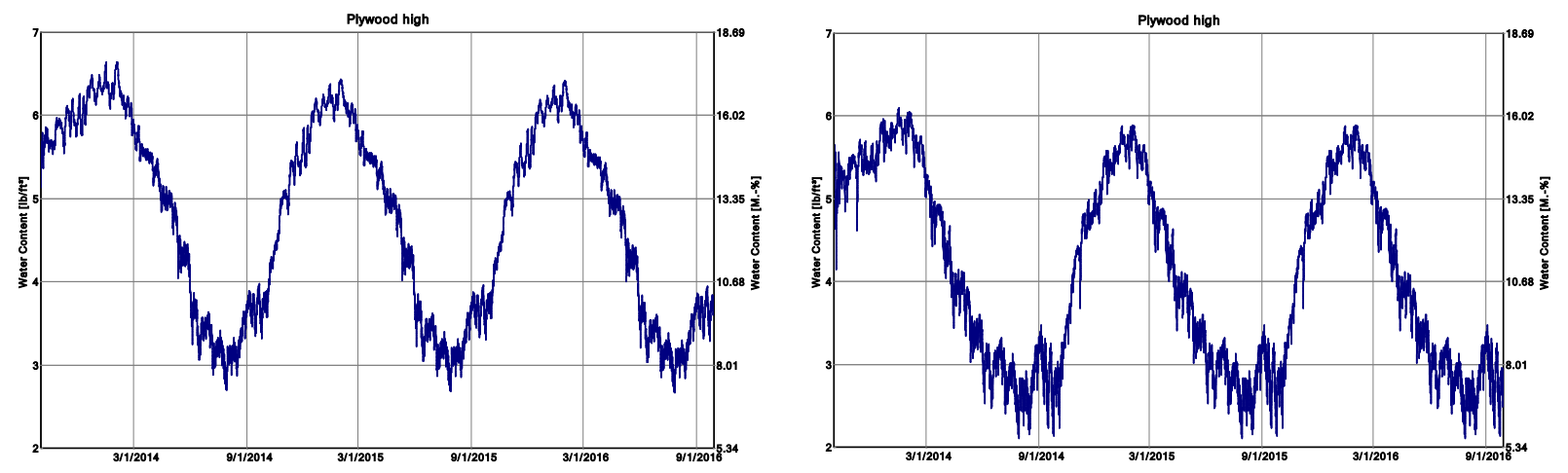

Figure 102. Round 3, Wall 2 sheathing MC in Seattle (Zone 4C), north (left) and south (right)
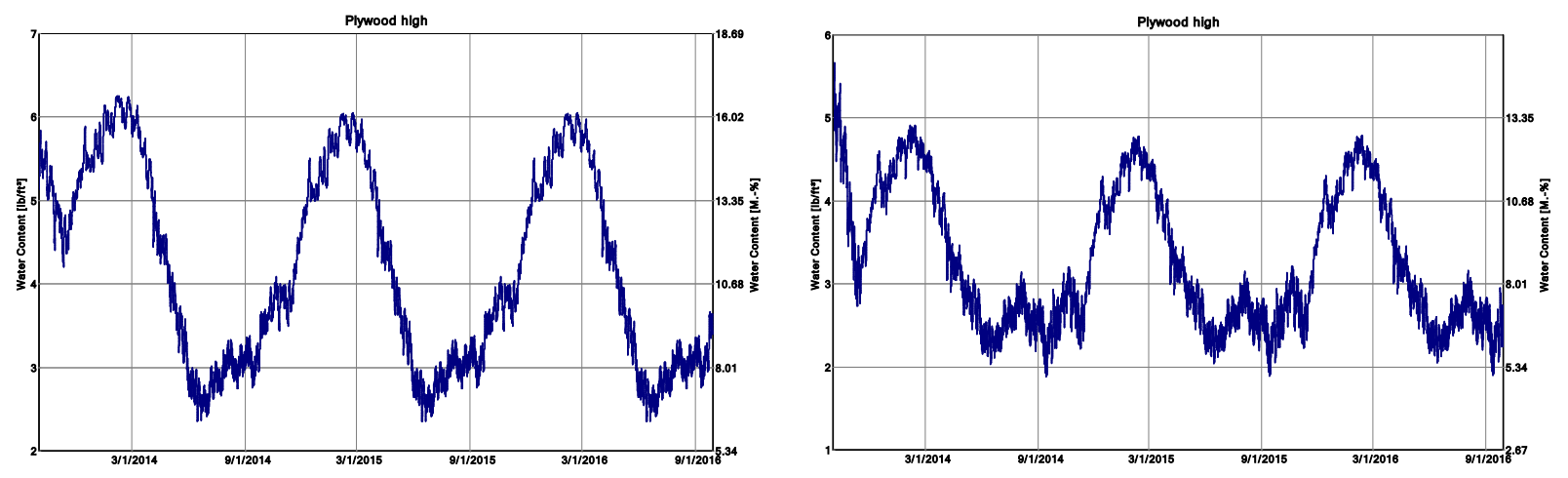

Figure 103. Round 3, Wall 2 sheathing MC in Chicago (Zone 5A), north (left) and south (right) 

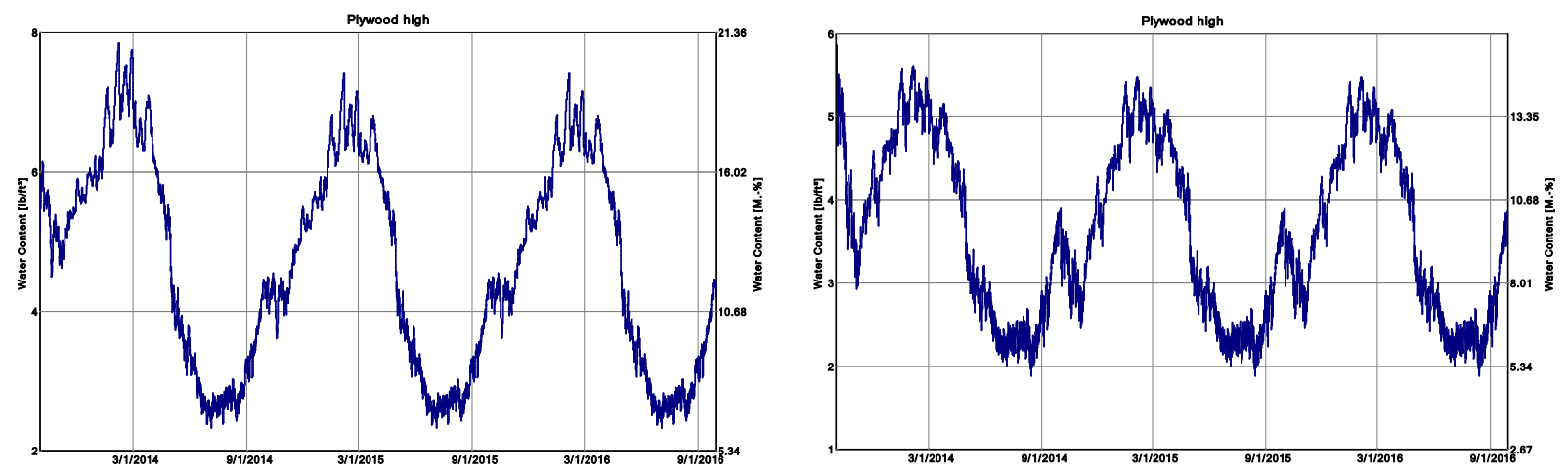

Figure 104. Round 3, Wall 2 sheathing MC in Minneapolis (Zone 6A), north (left) and south (right)

\subsubsection{Wall 3 (Vinyl-OSB)}

Table 21 describes the layers and their respective functions in the Round 3, Wall 3 configuration, and Figure 105 shows the layers from exterior to interior.

Table 21. Round 3, Wall 3 (Vinyl-OSB) layers

\begin{tabular}{ll}
\hline Layer & Function \\
\hline Vinyl siding & provides exterior finish for aesthetics \\
\hline Asphalt saturated Kraft paper (building paper) & functions as air and water control layer \\
\hline OSB sheathing & provides structural support \\
\hline 2x6 framing & provides structural support \\
\hline R-19 fiberglass batt & functions as thermal control layer \\
\hline 6-mil polyethylene & functions as vapor control layer \\
\hline Gypsum wall board & provides interior finish \\
\hline Latex paint & functions as vapor drive throttle \\
\hline
\end{tabular}




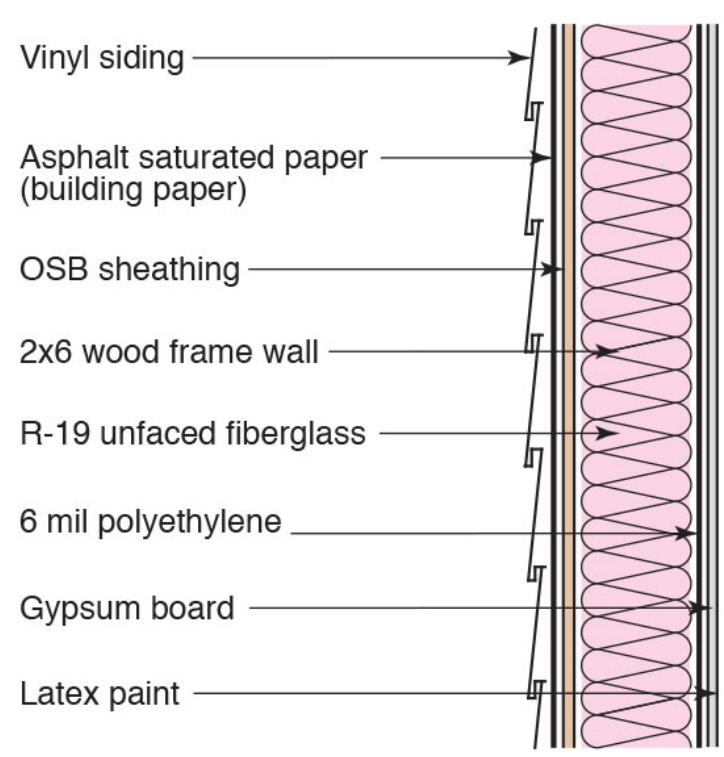

Figure 105. Round 3, Wall 3 (Vinyl-OSB) configuration

WUFI simulations are run on this wall on both north and south orientations in six climate zones; Figure 106 to Figure 111 show the MC graphs of the inner face of wall sheathing over a period of 3 years.
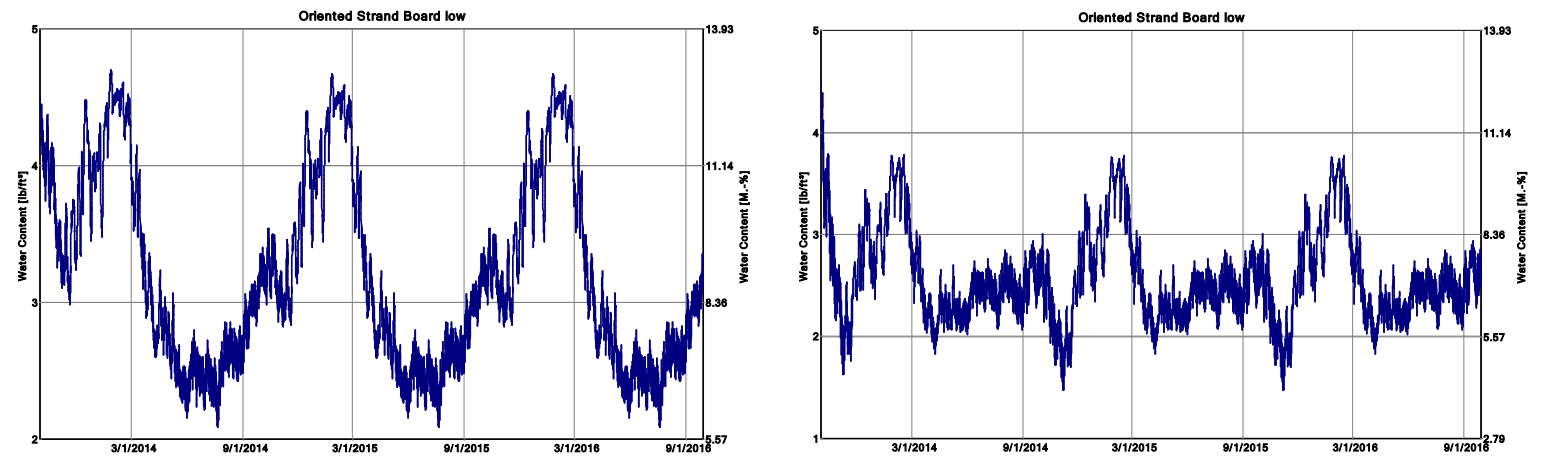

Figure 106. Round 3, Wall 3 sheathing MC in Houston (Zone 2A), north (left) and south (right)
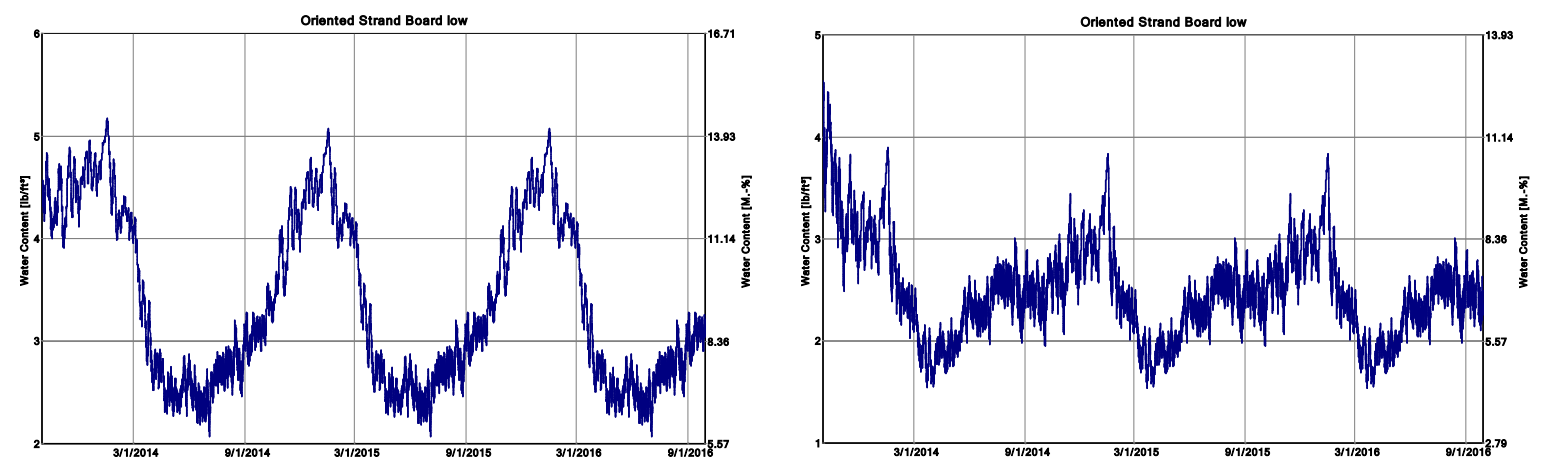

Figure 107. Round 3, Wall 3 sheathing MC in Atlanta (Zone 3A), north (left) and south (right) 

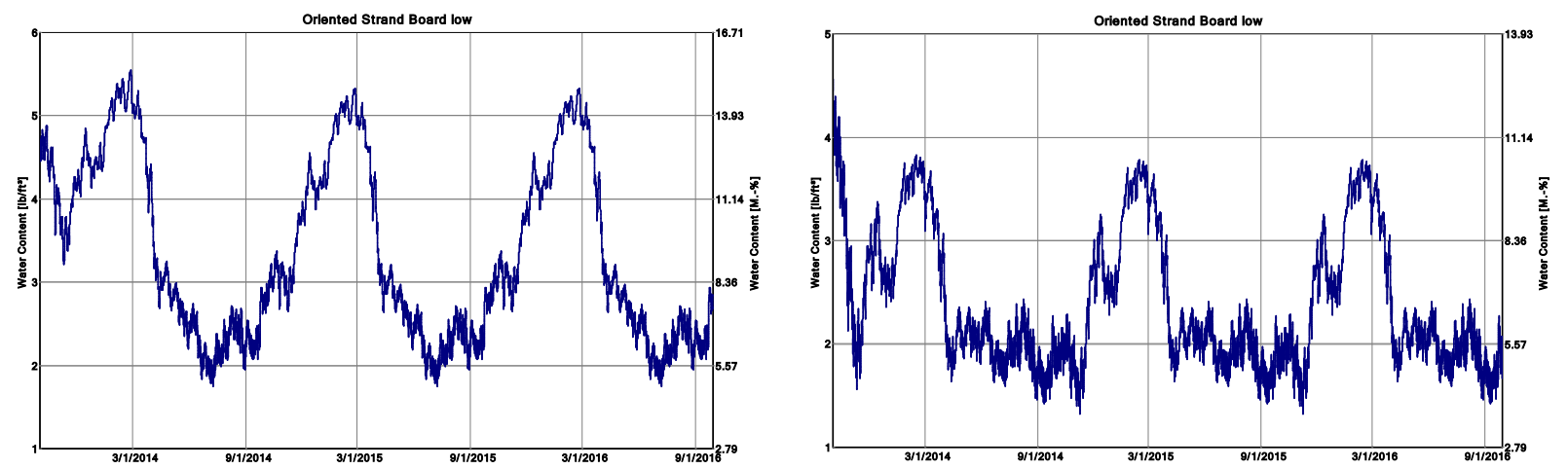

Figure 108. Round 3, Wall 3 sheathing MC in Kansas City (Zone 4A), north (left) and south (right)
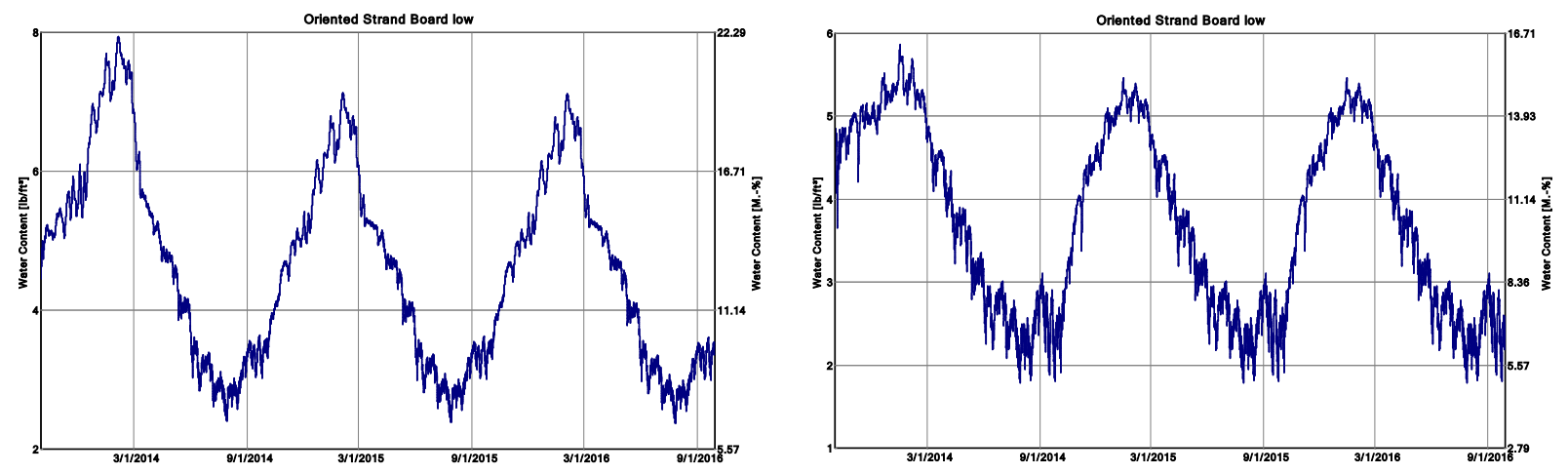

Figure 109. Round 3, Wall 3 sheathing MC in Seattle (Zone 4C), north (left) and south (right)
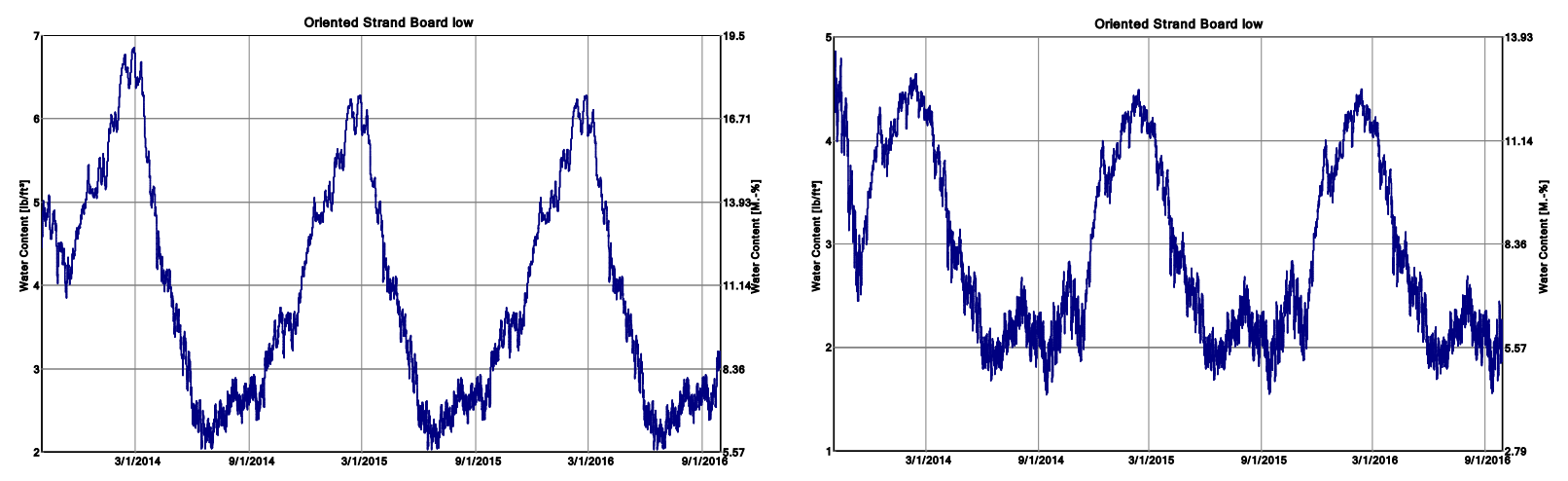

Figure 110. Round 3, Wall 3 sheathing MC in Chicago (Zone 5A), north (left) and south (right) 

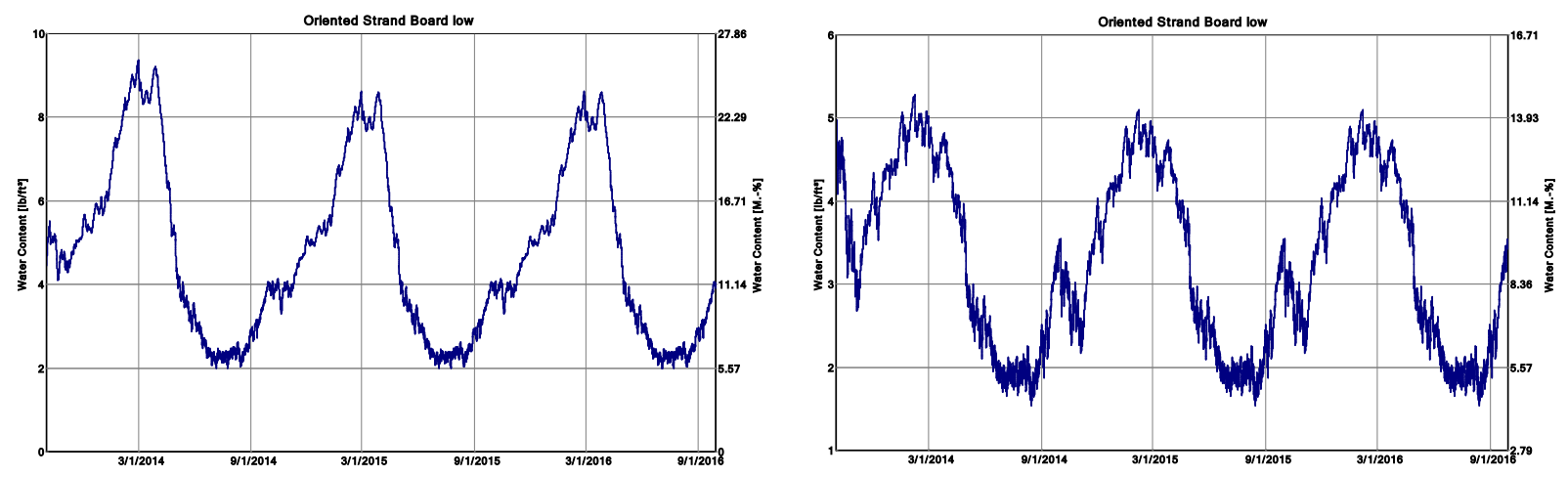

Figure 111. Round 3, Wall 3 sheathing MC in Minneapolis (Zone 6A), north (left) and south (right)

\subsubsection{Wall 4 (Brick-OSB)}

Table 22 describes the layers and their respective functions in the Round 3, Wall 4 configuration, and Figure 112 shows the layers from exterior to interior.

Table 22. Round 3, Wall 4 (Brick-OSB) layers

\begin{tabular}{ll}
\hline Layer & Function \\
\hline Brick veneer & provides exterior finish for aesthetics \\
\hline Asphalt saturated Kraft paper (building paper) & functions as air and water control layer \\
\hline OSB sheathing & provides structural support \\
\hline 2x6 framing & provides structural support \\
\hline R-19 fiberglass batt & functions as thermal control layer \\
\hline 6-mil polyethylene & functions as vapor control layer \\
\hline Gypsum wall board & provides interior finish \\
\hline Latex paint & functions as vapor drive throttle \\
\hline
\end{tabular}




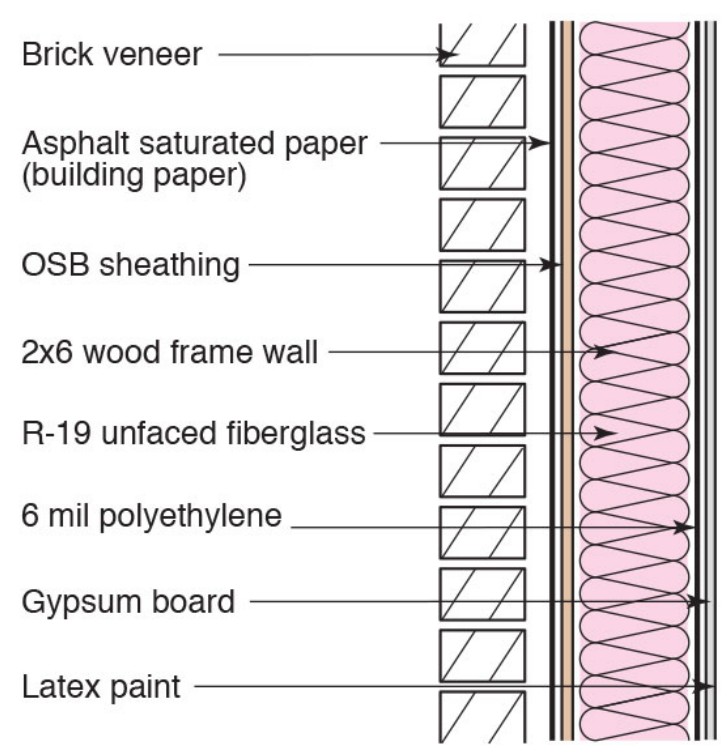

Figure 112. Round 3, Wall 4 (Brick-OSB) configuration

WUFI simulations are run on this wall on both north and south orientations in six climate zones; Figure 113 to Figure 118 show the MC graphs of the inner face of wall sheathing over a period of 3 years.
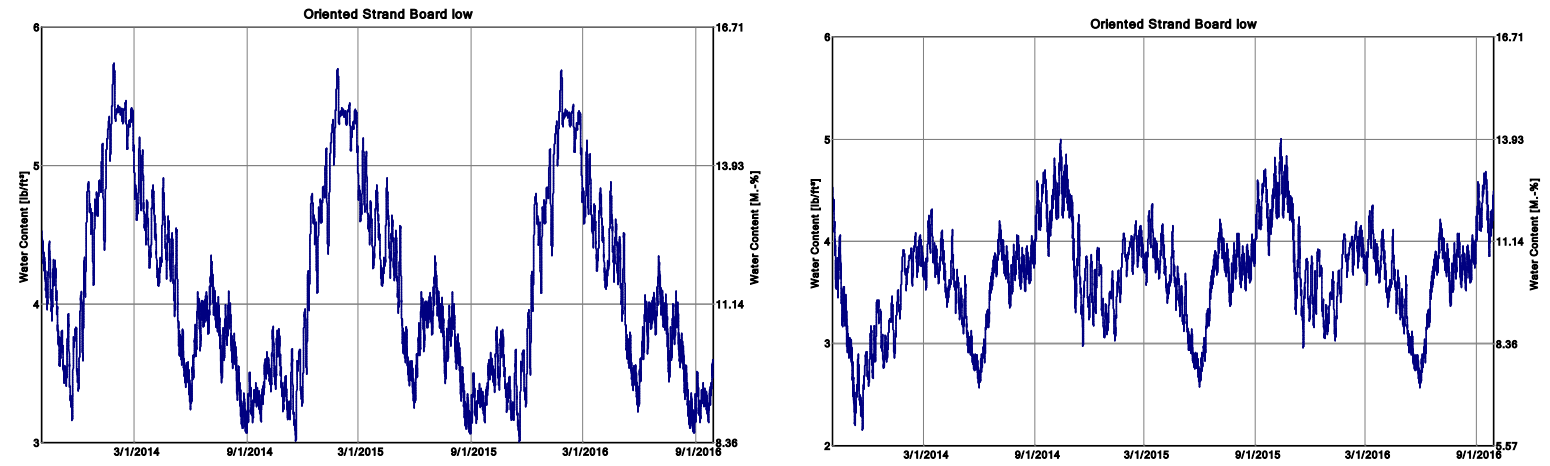

Figure 113. Round 3, Wall 4 sheathing MC in Houston (Zone 2A), north (left) and south (right)
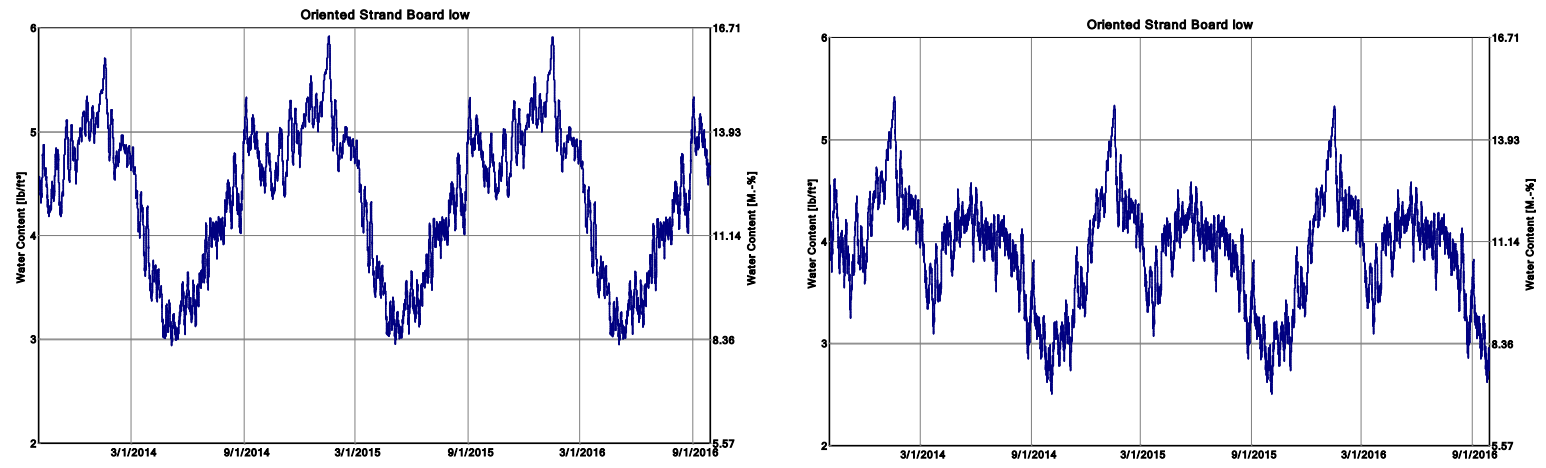

Figure 114. Round 3, Wall 4 sheathing MC in Atlanta (Zone 3A), north (left) and south (right) 

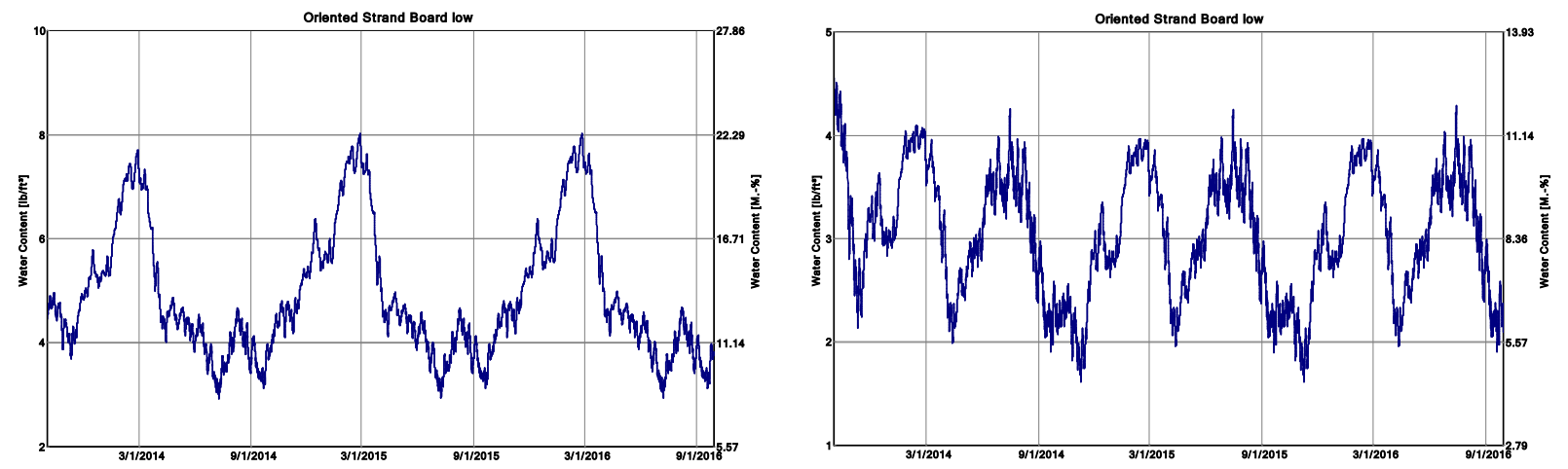

Figure 115. Round 3, Wall 4 sheathing MC in Kansas City (Zone 4A), north (left) and south (right)
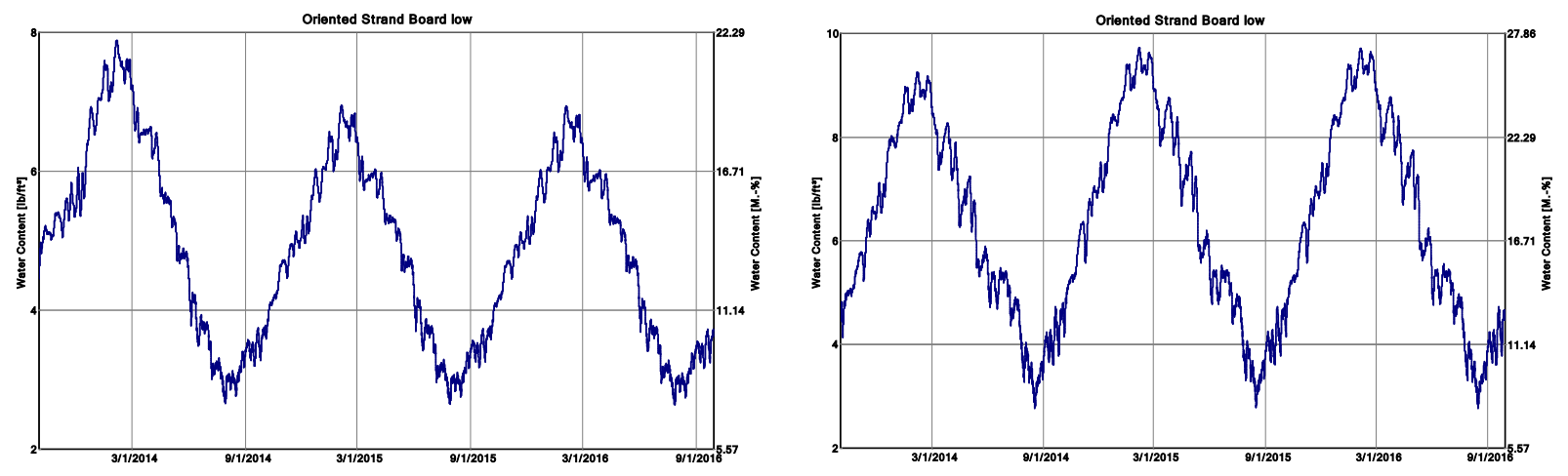

Figure 116. Round 3, Wall 4 sheathing MC in Seattle (Zone 4C), north (left) and south (right)
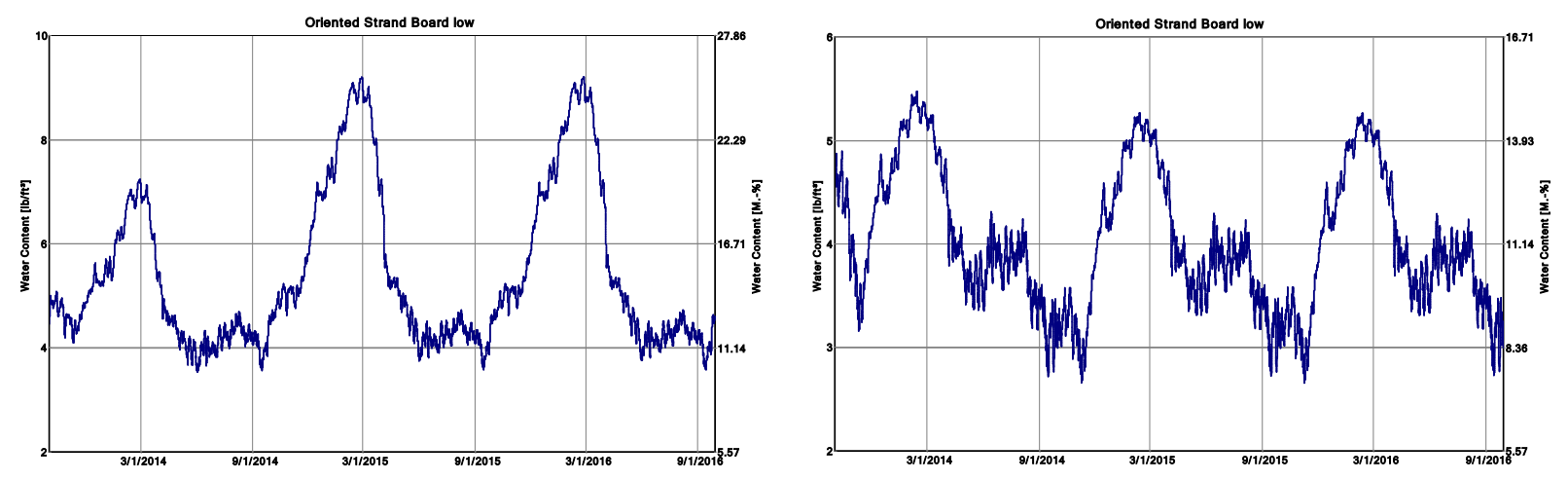

Figure 117. Round 3, Wall 4 sheathing MC in Chicago (Zone 5A), north (left) and south (right) 

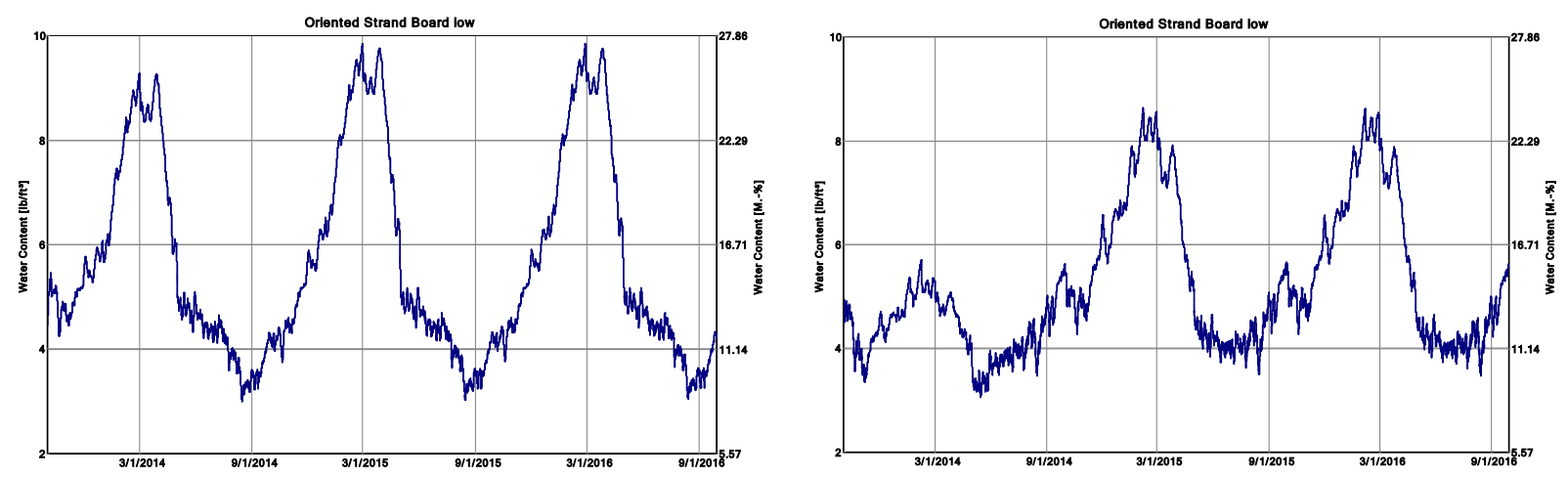

Figure 118. Round 3, Wall 4 sheathing MC in Minneapolis (Zone 6A), north (left) and south (right)

\subsubsection{Wall 5 (Stucco-OSB)}

Table 23 describes the layers and their respective functions in the Round 3, Wall 5 configuration, and Figure 119 shows the layers from exterior to interior.

Table 23. Round 3, Wall 5 (Stucco-OSB) layers

\begin{tabular}{ll}
\hline Layer & Function \\
\hline Stucco & provides exterior finish for aesthetics \\
\hline $\begin{array}{l}\text { 2 layers asphalt saturated Kraft paper } \\
\text { (building paper) }\end{array}$ & functions as air and water control layer \\
\hline OSB sheathing & provides structural support \\
\hline 2x6 framing & provides structural support \\
\hline R-19 fiberglass batt & functions as thermal control layer \\
\hline 6-mil polyethylene & functions as vapor control layer \\
\hline Gypsum wall board & provides interior finish \\
\hline Latex paint & functions as vapor drive throttle \\
\hline
\end{tabular}




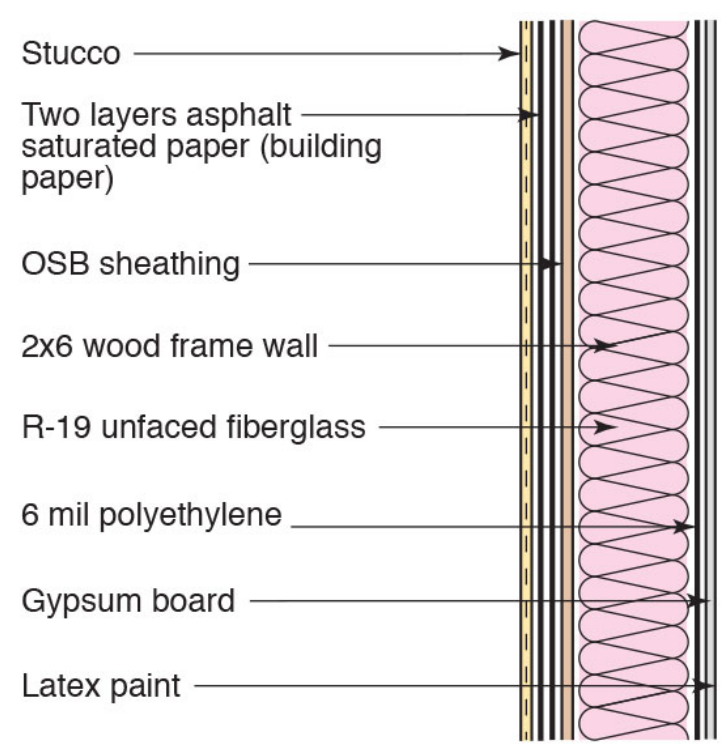

Figure 119. Round 3, Wall 5 (Stucco-OSB) configuration

WUFI simulations are run on this wall on both north and south orientations in six climate zones; Figure 120 to Figure 125 show the MC graphs of the inner face of wall sheathing over a period of 3 years.
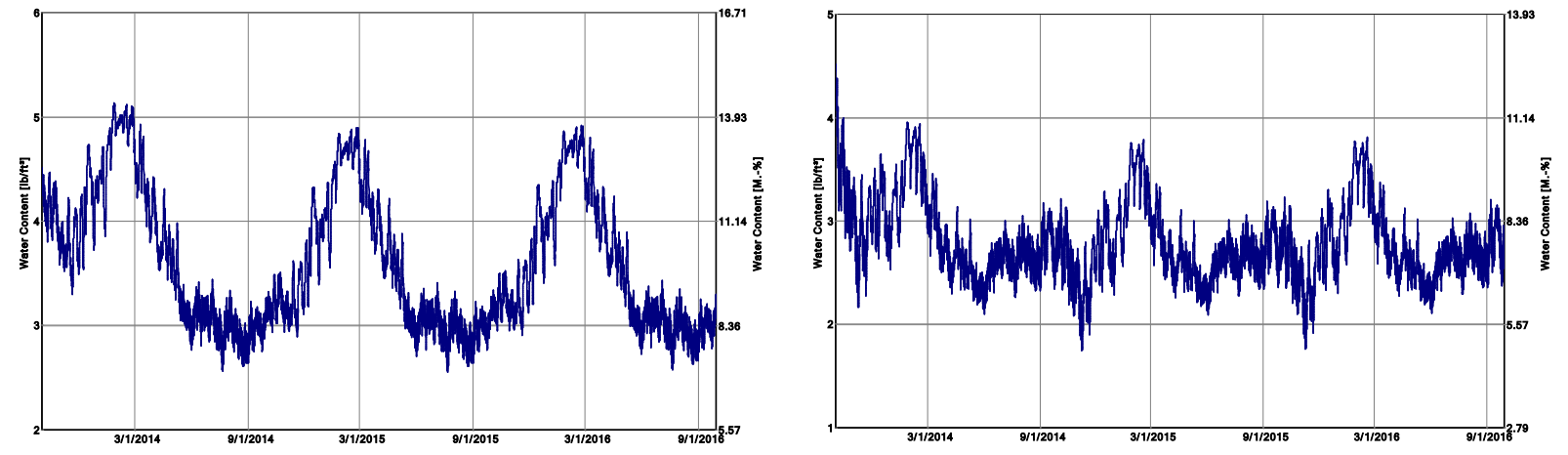

Figure 120. Round 3, Wall 5 sheathing MC in Houston (Zone 2A), north (left) and south (right)
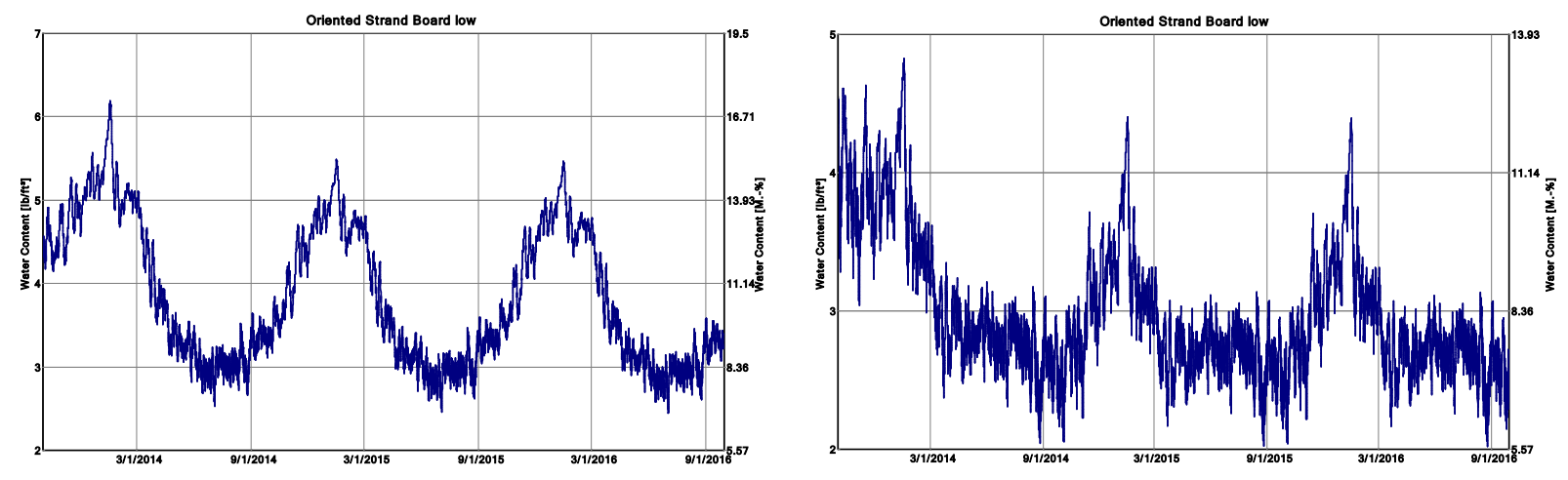

Figure 121. Round 3, Wall 5 sheathing MC in Atlanta (Zone 3A), north (left) and south (right) 

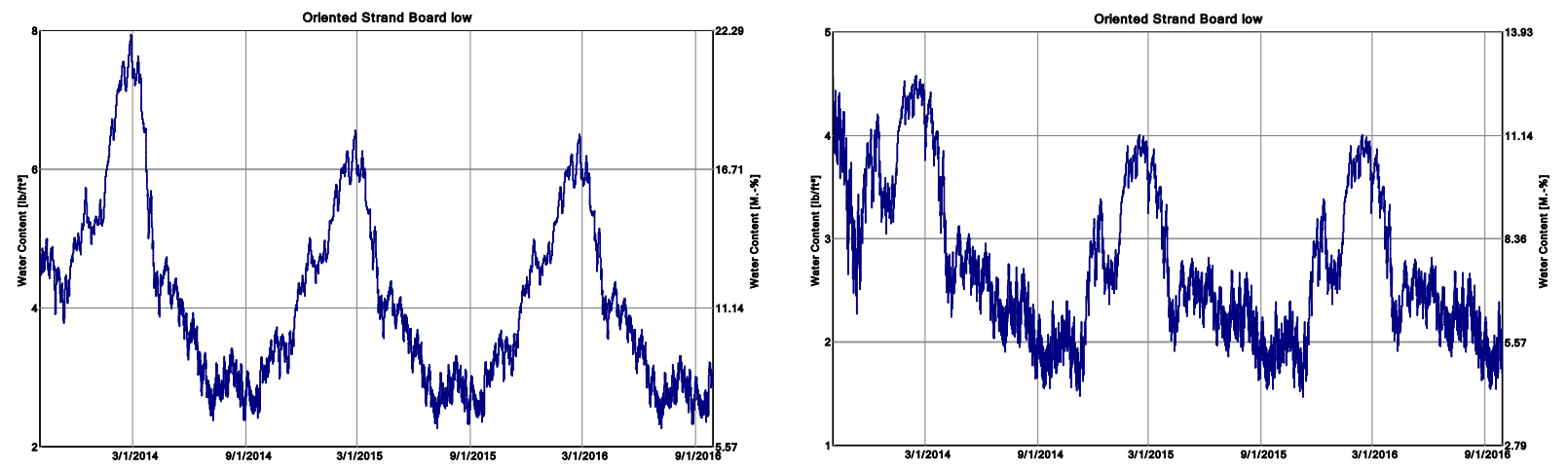

Figure 122. Round 3, Wall 5 sheathing MC in Kansas City (Zone 4A), north (left) and south (right)
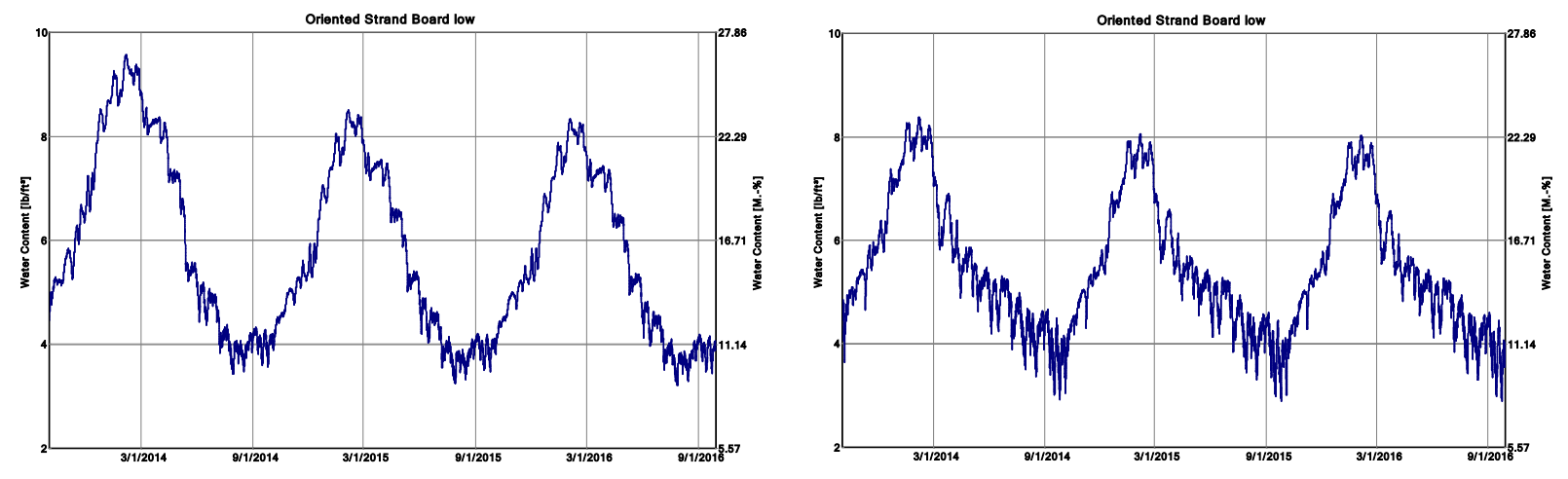

Figure 123. Round 3, Wall 5 sheathing MC in Seattle (Zone 4C), north (left) and south (right)
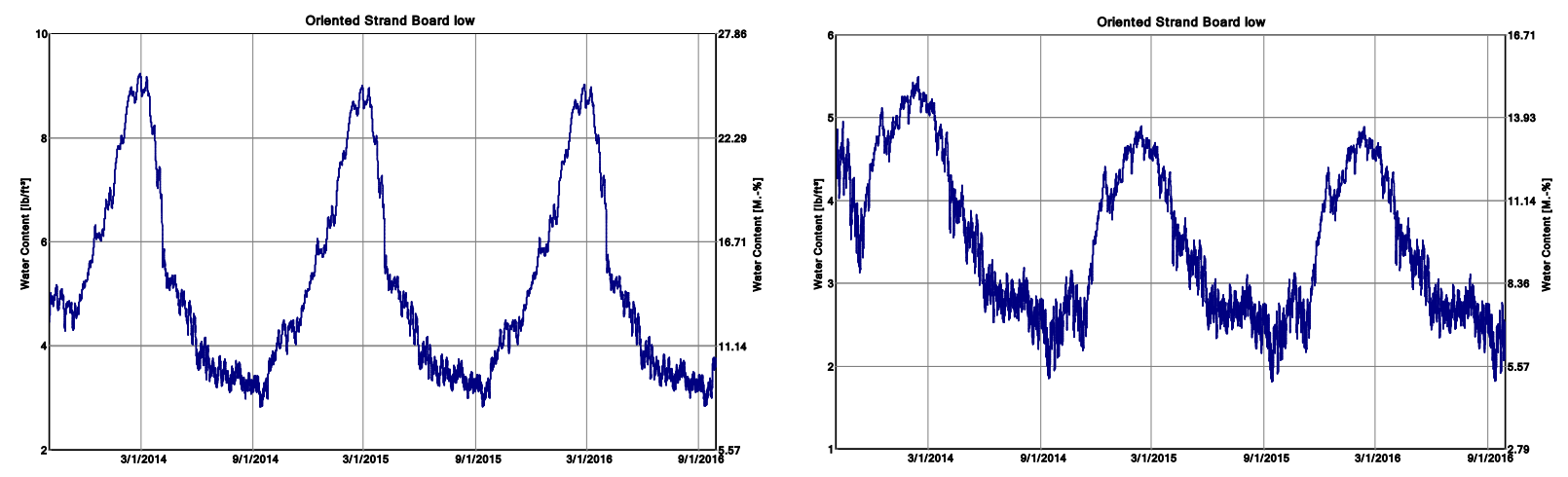

Figure 124. Round 3, Wall 5 sheathing MC in Chicago (Zone 5A), north (left) and south (right) 

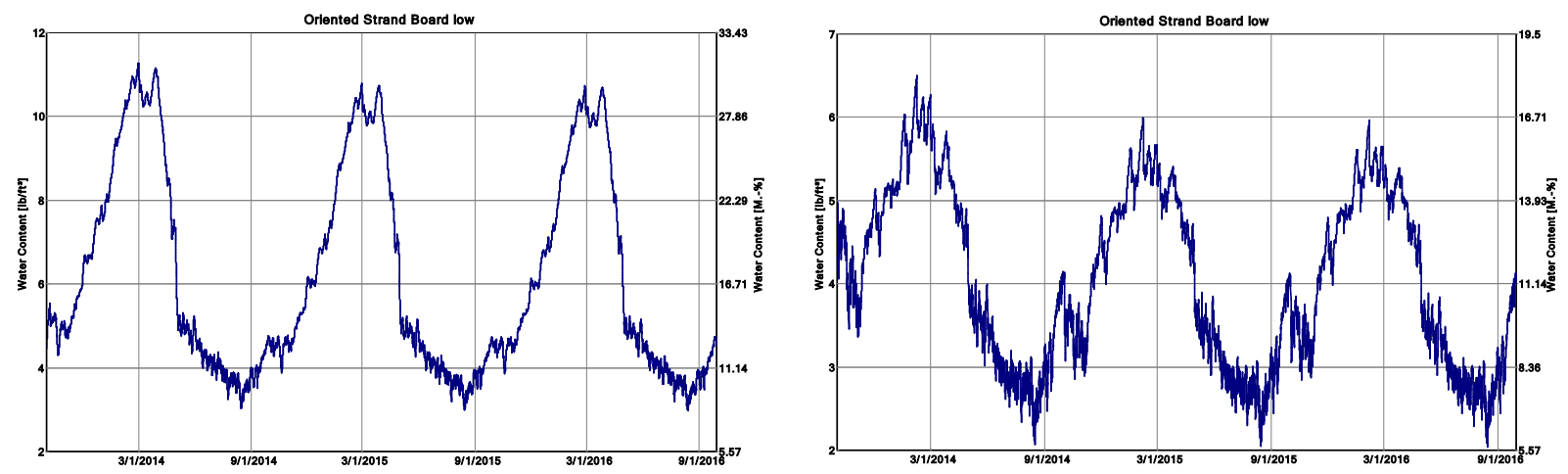

Figure 125. Round 3, Wall 5 sheathing MC in Minneapolis (Zone 6A), north (left) and south (right)

\subsubsection{Wall 6 (Vented Stucco-OSB)}

Table 24 describes the layers and their respective functions in the Round 3, Wall 6 configuration, and Figure 126 shows the layers from exterior to interior.

Table 24. Round 3, Wall 6 (Vented Stucco-OSB) layers

\begin{tabular}{ll}
\hline Layer & Function \\
\hline Stucco & provides exterior finish for aesthetics \\
\hline $\begin{array}{l}1 \text { layer asphalt saturated Kraft paper } \\
\text { (building paper) }\end{array}$ & provides backing for stucco \\
\hline $\begin{array}{l}\text { Polypropylene drainage mat }(1 / 2 \text { in.) } \\
\text { Another layer asphalt saturated Kraft paper } \\
\text { (building paper) }\end{array}$ & provides drainage and ventilation gap \\
\hline OSB sheathing & functions as air and water control layer \\
\hline 2x6 framing & provides structural support \\
\hline R-19 fiberglass batt & provides structural support \\
\hline 6-mil polyethylene & functions as thermal control layer \\
\hline Gypsum wall board & functions as vapor control layer \\
\hline Latex paint & provides interior finish \\
\hline
\end{tabular}




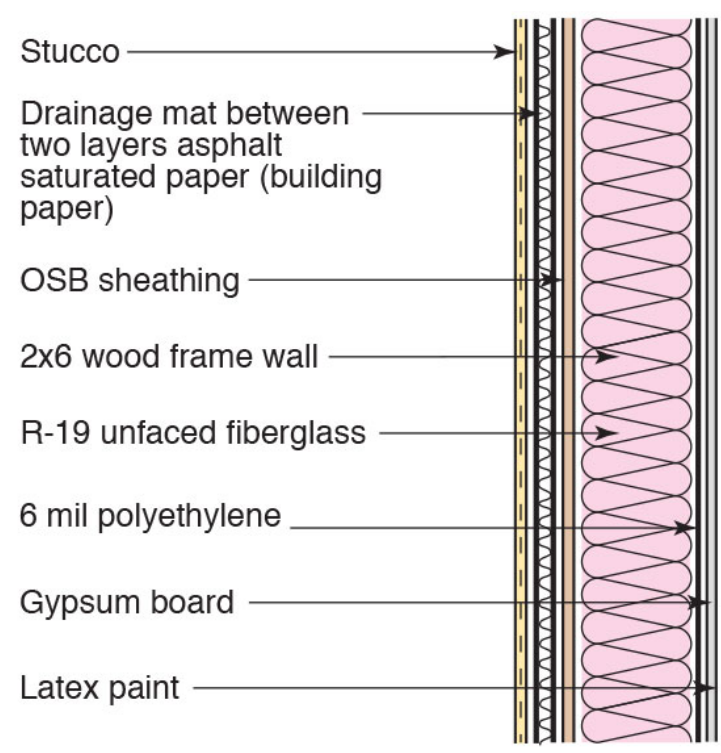

Figure 126. Round 3, Wall 6 (Vented Stucco-OSB) configuration

WUFI simulations are run on this wall on both north and south orientations in six climate zones; Figure 127 to Figure 132 show the MC graphs of the inner face of wall sheathing over a period of 3 years.
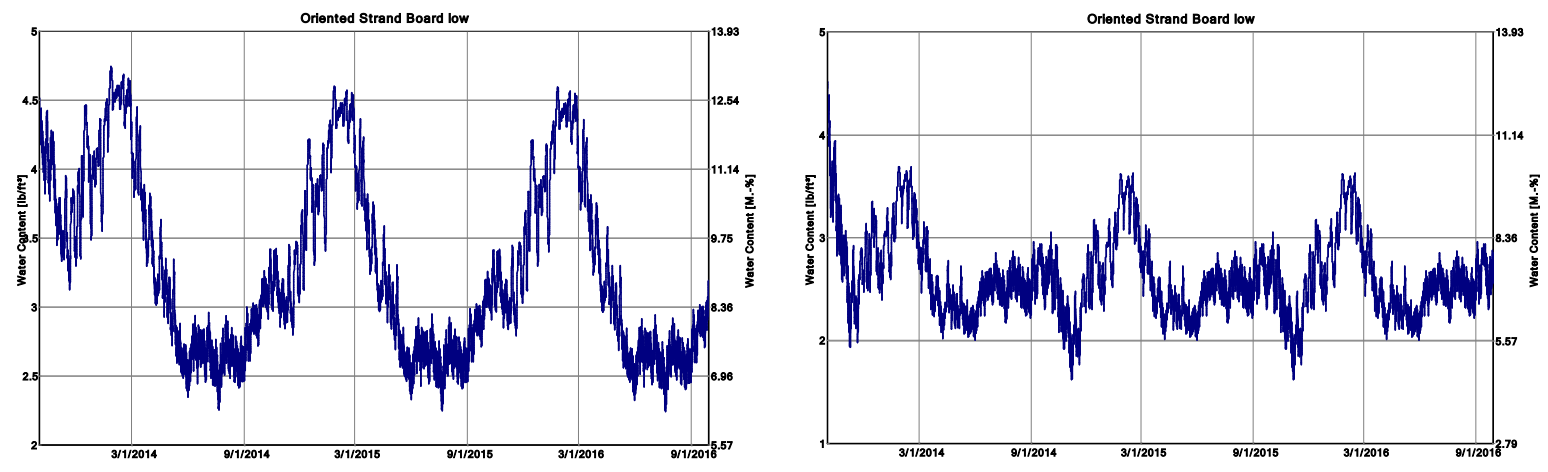

Figure 127. Round 3, Wall 6 sheathing MC in Houston (Zone 2A), north (left) and south (right)
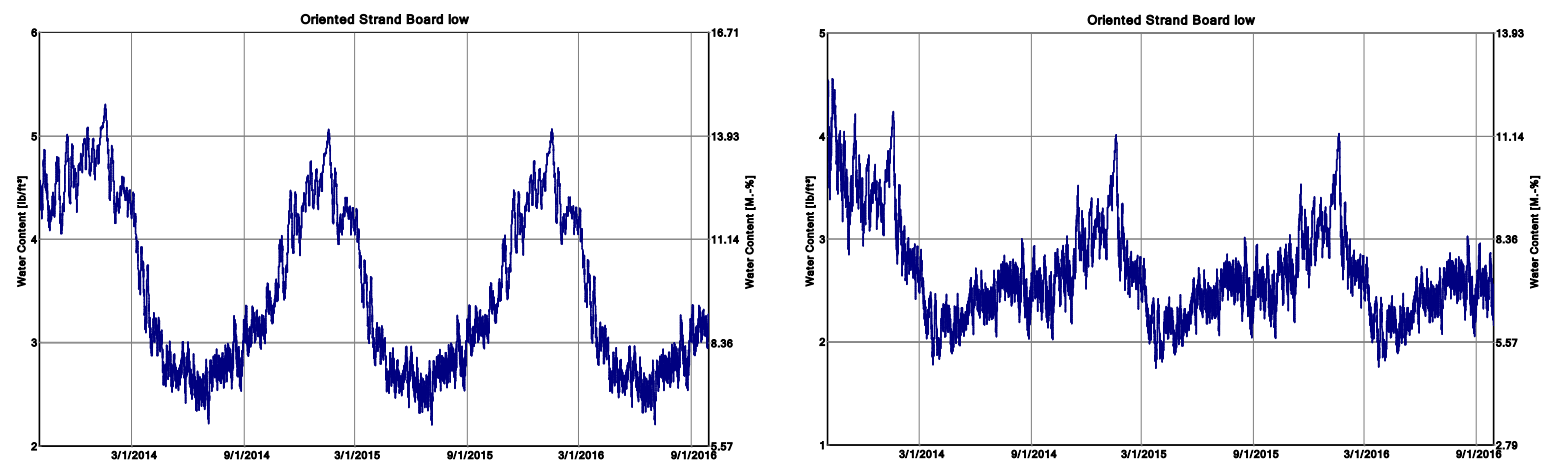

Figure 128. Round 3, Wall 6 sheathing MC in Atlanta (Zone 3A), north (left) and south (right) 

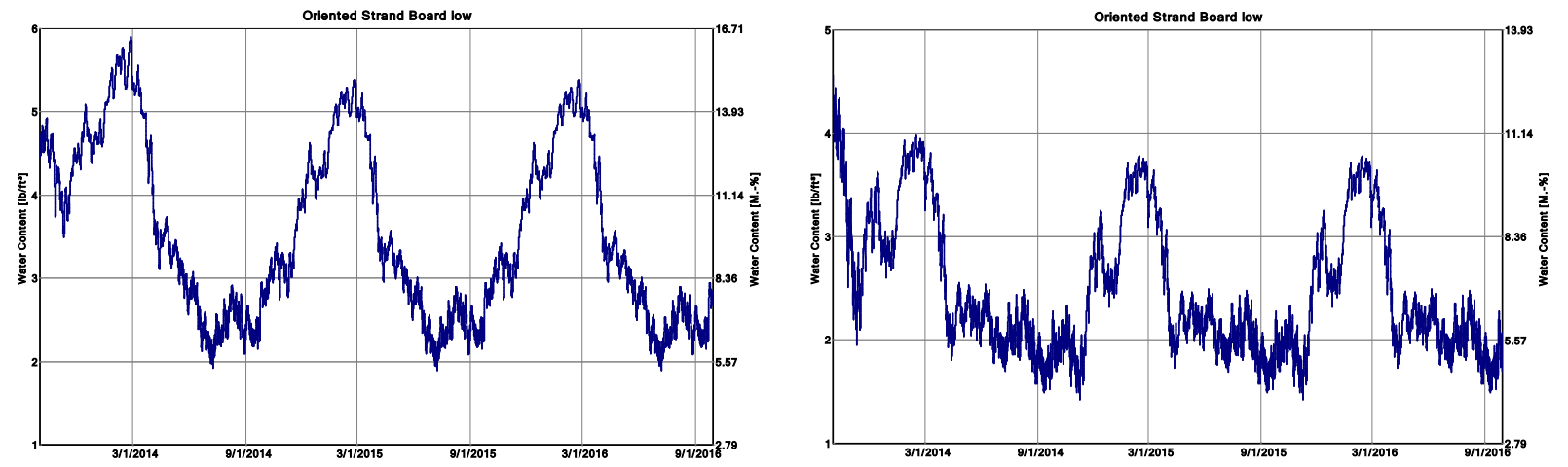

Figure 129. Round 3, Wall 6 sheathing MC in Kansas City (Zone 4A), north (left) and south (right)
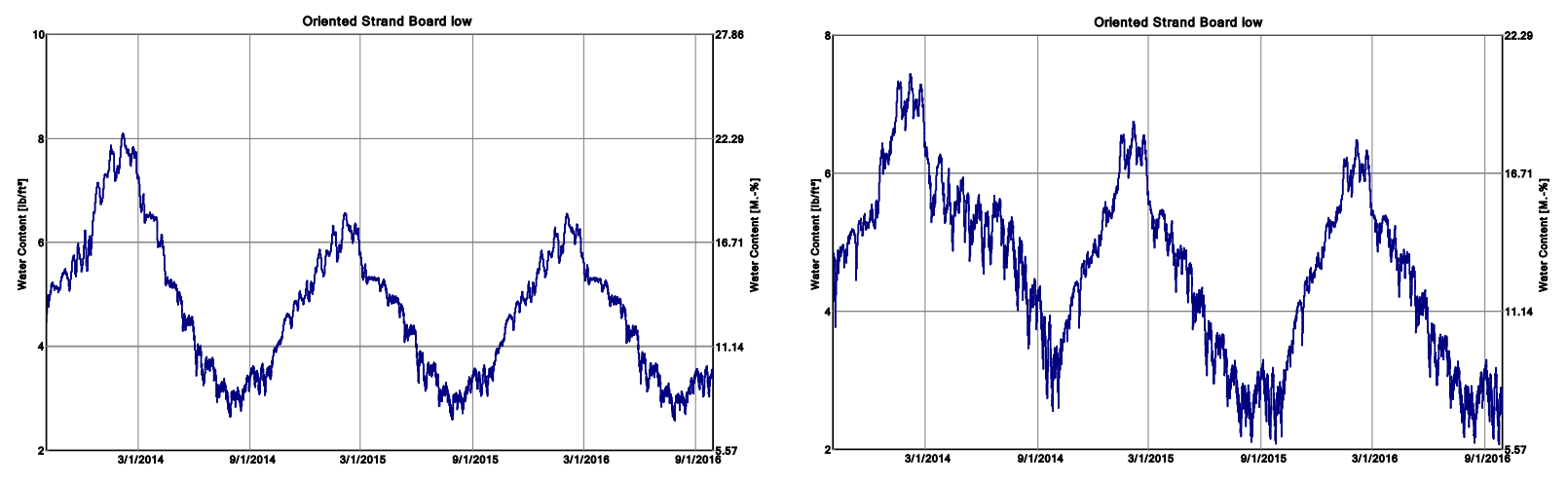

Figure 130. Round 3, Wall 6 sheathing MC in Seattle (Zone 4C), north (left) and south (right)
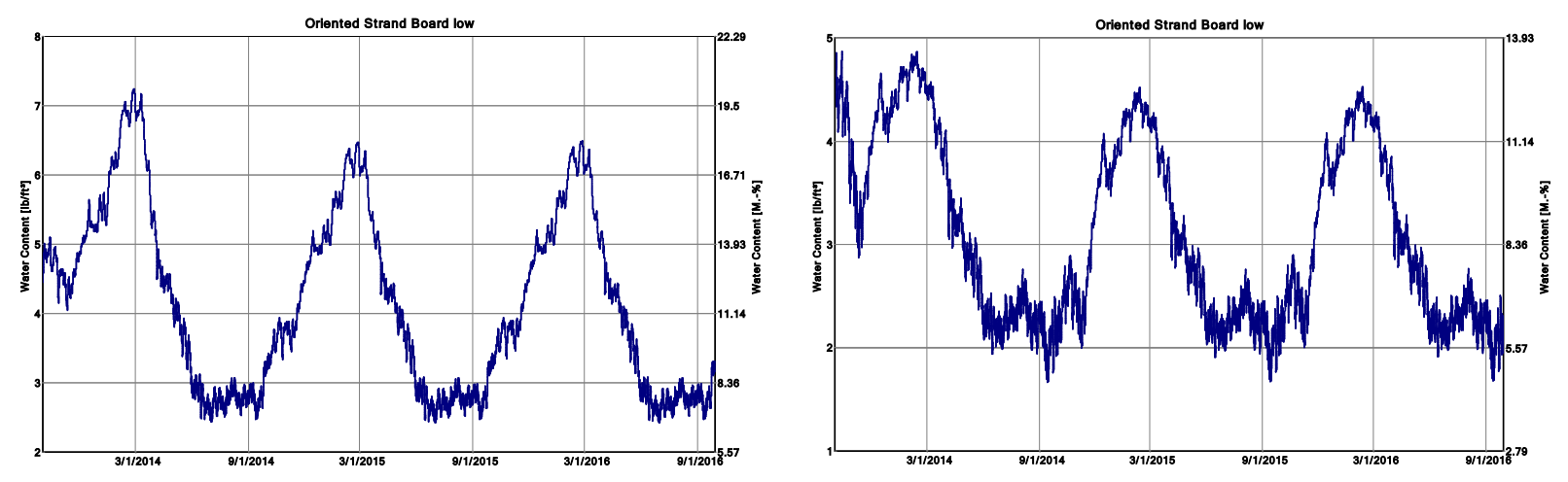

Figure 131. Round 3, Wall 6 sheathing MC in Chicago (Zone 5A), north (left) and south (right) 

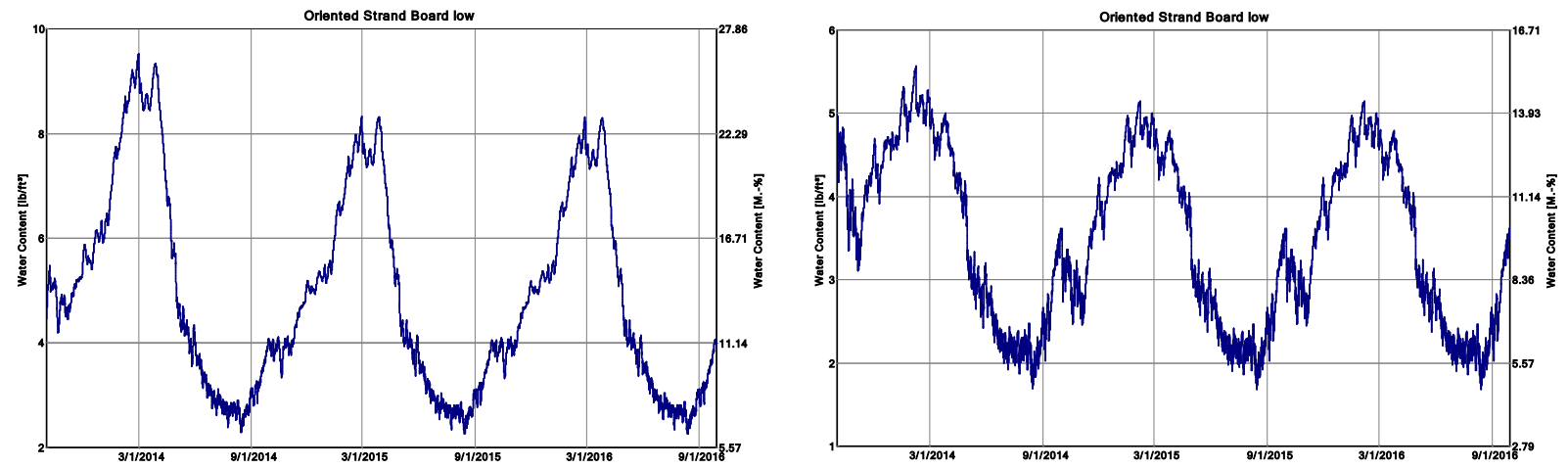

Figure 132. Round 3, Wall 6 sheathing MC in Minneapolis (Zone 6A), north (left) and south (right) 


\section{Conclusions}

This technical report describes the modeling of typical wall assemblies that have historically performed well in various climate zones. The WUFI Version 5.3 software model was used and a library of input data and results are provided. This information can be generalized for application to a broad population of houses, within the limits of existing experience.

The WUFI software model was calibrated or "tuned" using wall assemblies with historically successful performance. The primary performance criteria or failure criteria establishing historic performance was MC of the exterior sheathing: more specifically, historic reports of decay based on observation of large numbers of wall assemblies (buildings) over a decade or longer. The primary tuning parameters (simulation inputs) were specifying airflow and appropriate material properties. "Rational" hygric loads were established based on experience: specifically rain wetting and interior moisture (RH) levels. The tuning parameters were limited or bounded by published data or experience.

The WUFI software model is a one-dimensional combined heat and moisture flow model. Typical building assemblies are multilayer systems with complex three-dimensional airflow pathways. One-dimensional combined heat and moisture flow models have proven difficult to use for analysis in these types of assemblies due to the complexity added by the airflow component.

One challenge for a one-dimensional combined heat and moisture flow model is to address the rain and airflow components.

Rain is a significant moisture load. Modeling the rain transport mechanism - a three-dimensional phenomena in a multilayer system — adds more complexity. The WUFI rain modeling inputs had the following assumptions:

- Thirty percent of this water bounces off the wall, and $70 \%$ is retained on the wall.

- One percent of the $70 \%$ (the "retained water') is assumed to penetrate to the back side of the cladding.

- One percent of the $1 \%$ is assumed to penetrate the water control layer and enter into the sheathing.

WUFI software is capable of modeling cladding ventilation by introducing interior- or exteriorcondition air into an air space within the assembly. This allows for explicit (and correct) modeling of ventilated rain-screen behaviors, including vinyl siding (bypass of vaporimpermeable vinyl material with airflow) or brick veneer construction.

This airflow model within WUFI also allows the analysis of "through the assembly airflow" (i.e., air leakage through typical imperfect assemblies). This flow can be approximated as follows. Two arbitrary 5-mm ( ${ }^{3} / 16$-in.) air spaces are created at the interface of the cavity insulation and the structural sheathing. One air space is coupled to the interior, simulating air-transported moisture from the interior to the interior face of the exterior sheathing. The other air space is coupled to the exterior, and simulates air leakage from the exterior into the cavity. 
Running the rainwater- and airflow-"tuned" WUFI software model generated the library of input data and results presented. The results agree with historical experience of these assemblies constructed in the climate zones modeled.

The WUFI templates provided with this report supply useful information resources to new or less-experienced users. The files present various custom settings that will help avoid results that will require overly conservative enclosure assemblies. Overall, better material data, consistent initial assumptions, and consistent inputs among practitioners will improve the quality of WUFI modeling and the level of sophistication in the field. 


\section{References}

ASHRAE. 2013. 2013 ASHRAE Handbook-Fundamentals. American Society of Heating, Refrigerating, and Air-Conditioning Engineers, Atlanta, GA. Accessed January 29, 2016. https://www.ashrae.org/resources--publications/handbook/description-of-the-2013-ashraehandbook--fundamentals.

ASHRAE. 2009. ANSI/ASHRAE Standard 160-2009, Criteria for Moisture-Control Design Analysis in Buildings (ANSI/ASHRAE Approved). American Society of Heating, Refrigerating, and Air-Conditioning Engineers, Atlanta, GA.

Hutcheon, N. and Handegord, G. 1983. Building Science for a Cold Climate. ISBN: 0-96943660-2, National Research Council of Canada, Ottawa, ON.

Kumaran, M., Mitalas, G., and Bomberg, M. 1994. Fundamentals of Transport and Storage of Moisture in Building Materials and Components. ASTM Manual Round: MNL 18, Philadelphia, PA, February 1994.

Künzel, H. 2002. "WUFI ${ }^{\circledR}$ PC-Program for calculating the coupled heat and moisture transfer in buildings," Fraunhofer Institute for Building Physics. Holzkirchen, Germany.

Lstiburek, J.W. 2007. "Building Sciences: The Perfect Storm Over Stucco," ASHRAE Journal 50:38-43. Atlanta, GA: American Society of Heating, Refrigerating and Air-Conditioning Engineers, Inc,. 2008.

NREL. 2013. FY 2014 Residential Energy System Research Needs. National Renewable Energy Laboratory, Golden, CO, 25 pp.

NREL. 2013. Building America Technical Innovations Leading to 50\% Savings - A Critical Path. National Renewable Energy Laboratory, Golden, Co.

Ojanen, T., Kohonen, R., and Kumaran, M. 1994. Modeling Heat, Air and Moisture Transport Through Building Materials and Components. ASTM Manual Round: MNL 18, Philadelphia, PA, February 1994.

Shi, X., Schumacher, C., and Burnett, E. 2004. Ventilation Drying Under Simulated Climate Conditions-Report \#7, ASHRAE 1091 -Development of Design Strategies for Rainscreen and Sheathing Membrane Performance in Wood Frame Walls. The Pennsylvania Housing Research/Resource Center, Pennsylvania State University Report for ASHRAE. University Park, PA.

Straube, J. and Burnett, E. 2005. Building Science for Building Enclosures, ISBN: 0-9755127-49, Building Science Press, Westford, MA.

Straube, J.F., Burnett, E., VanStraaten, R., and Schumacher, C. 2004. Review of Literature and Theory-Report \#1, ASHRAE 1091 - Development of Design Strategies for Rainscreen and Sheathing Membrane Performance in Wood Frame Walls. University of Waterloo, Building Engineering Group Report for ASHRAE. Waterloo, ON. 
Straube, J. and Smegal, J. 2009. Building America Special Research Project: High-R Walls Case Study Analysis. Building America Report - 0903, Building Science Corporation, Somerville, MA, March 11, 2009. Accessed December 4, 2012.

http://www.buildingscience.com/documents/bareports/ba-0903-building-america-specialresearch-project-high-r-walls/view.

Timusk, P.C. 2005. "Moisture Related Properties of Oriented Strand Board (OSB)," 10DBMC International Conference on Durability of Building Materials and Components, Lyon, France, April 17-20, 2005. Accessed January 29, 2016. http://www.section08.com/timuskmoist $\% 20$ rel $\% 20$ prop $\% 20$ osb $\% 2010 \mathrm{dbmc} \% 20$ full.pdf.

Ueno, K. and Lstiburek, J. 2014. Guidance on Modeling Enclosure Design in Above Grade Walls: Expert Meeting Report. Prepared by Building Science Corporation for the National Renewable Energy Laboratory on behalf of the U.S. Department of Energy, Golden, CO, June 14, 2014. Accessed January 29, 2016. http://buildingscience.com/documents/bareports/ba-1403guidance-modeling-enclosure-design-above-grade-walls-expert-meeting/view.

Viitanen, H. and Ritschkoff, A. 1991. Mould growth in pine and spruce sapwood in relation to air humidity and temperature. ISBN: 9157645221, Swedish University of Agriculture Sciences, Department of Forest Products, Uppsala, Sweden. 1991. 


\section{Appendix A. WUFI Component Assemblies Round 1, Wall 1 (Wood Siding-Ply)}

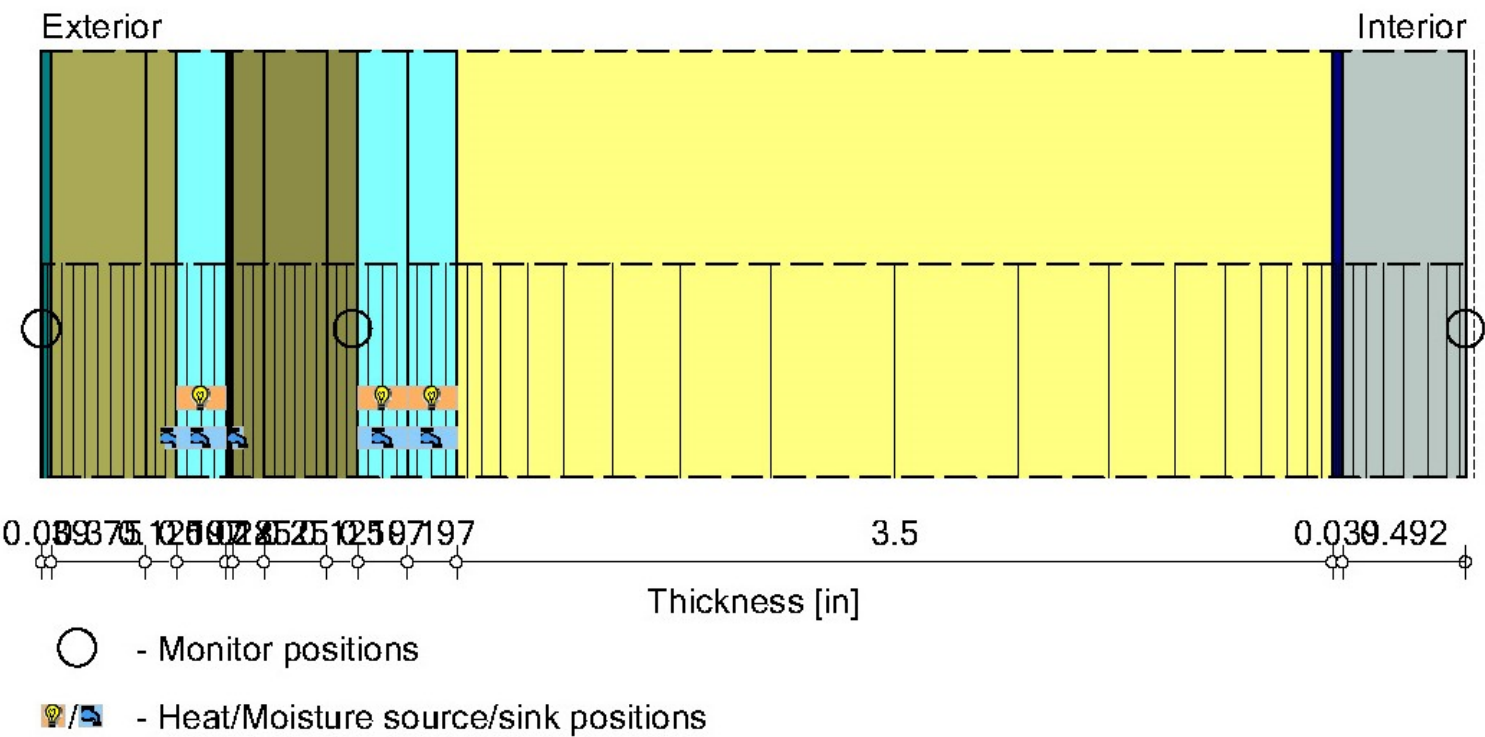

\section{Materials:}

\begin{tabular}{|c|c|}
\hline - *(BSC) Latex Paint \& Oil Primer for Wood Siding & $0.039 \mathrm{in}$ \\
\hline - *Southern Yellow Pine & 0.375 in \\
\hline - *Southern Yellow Pine & 0.125 in \\
\hline - *Air Layer $5 \mathrm{~mm}$; without additional moisture capacity & 0.197 in \\
\hline - 'Bituminous Paper (\#15 Felt) & 0.028 in \\
\hline - Plywood high & 0.125 in \\
\hline - Plywood high & $0.25 \mathrm{in}$ \\
\hline - Plywood high & $0.125 \mathrm{in}$ \\
\hline - *Air Layer 5 mm & 0.197 in \\
\hline - *Air Layer 5 mm & 0.197 in \\
\hline - *Fibre Glass (unlocked) & 3.5 in \\
\hline - *(BSC) Kraft Paper & 0.039 in \\
\hline - *Gypsum Board (USA) & 0.492 in \\
\hline
\end{tabular}

Sd-Value Int. [perm]: 10,0

Total Thickness: 5.69 in

R-Value: $18.03 \mathrm{~h} \mathrm{ft}^{2}{ }^{\circ} \mathrm{F} / \mathrm{Btu}$

U-Value: $0.052 \mathrm{Btu} / \mathrm{h} \mathrm{ft}^{2{ }^{\circ}} \mathrm{F}$ 


\section{Round 1, Wall 2 (Vinyl Siding-Ply)}

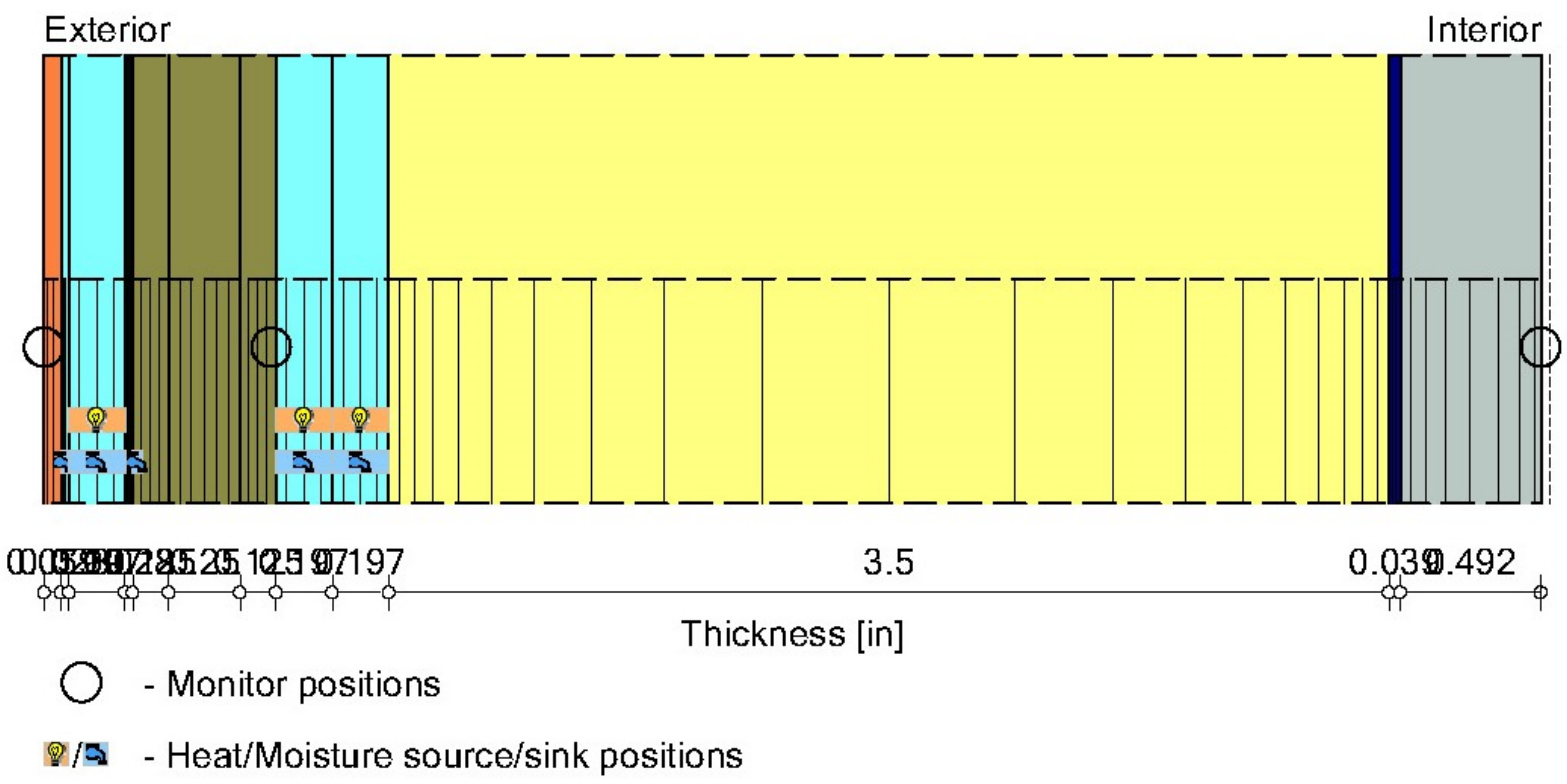

\section{Materials:}

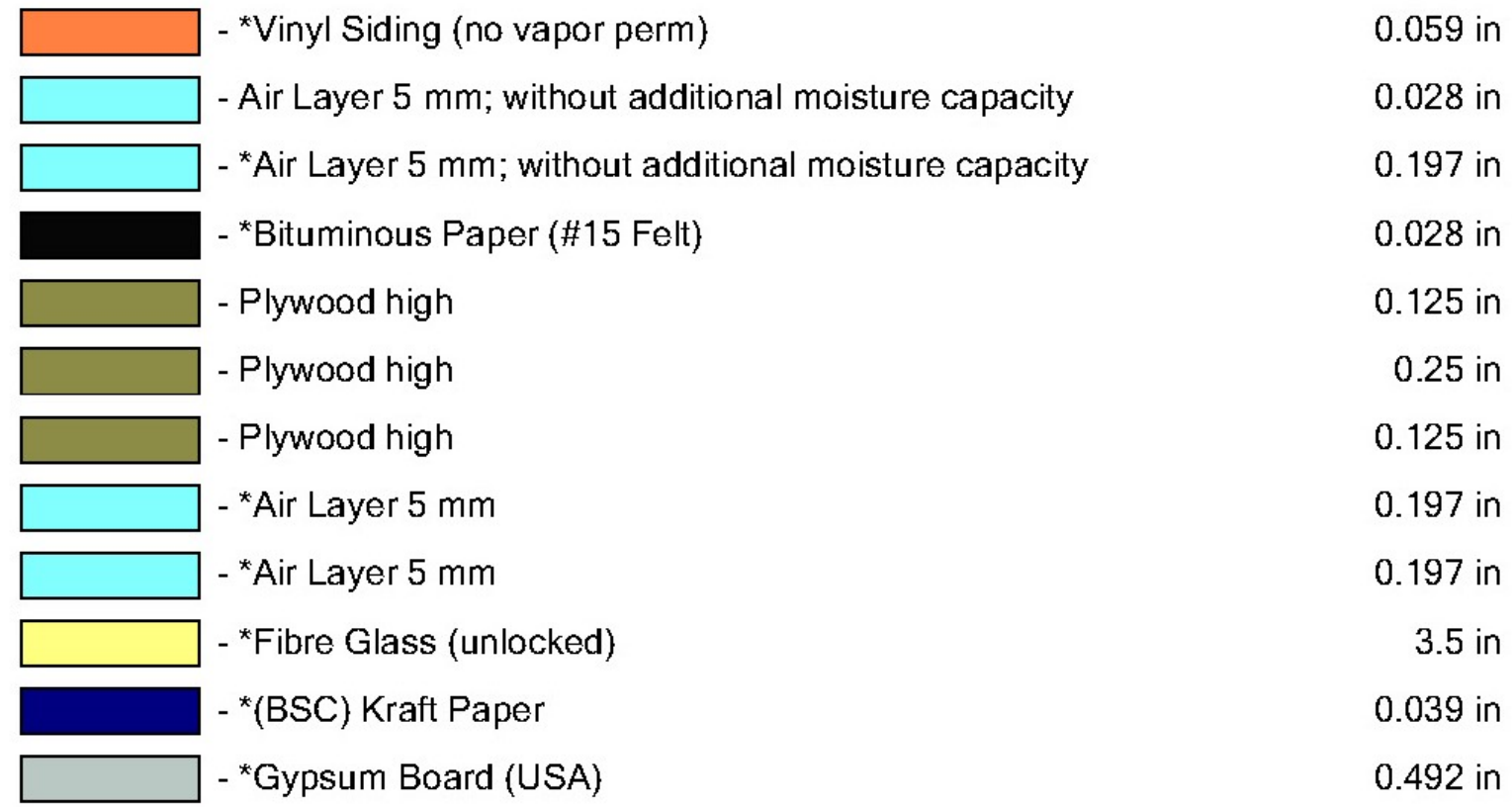

Sd-Value Int. [perm]: 10,0

Total Thickness: 5.24 in

R-Value: $17.56 \mathrm{~h} \mathrm{ft}^{2}{ }^{\circ} \mathrm{F} / \mathrm{Btu}$

U-Value: $0.054 \mathrm{Btu} / \mathrm{h} \mathrm{ft}{ }^{2 \circ} \mathrm{F}$ 


\section{Round 1, Wall 3 (Vinyl-OSB)}

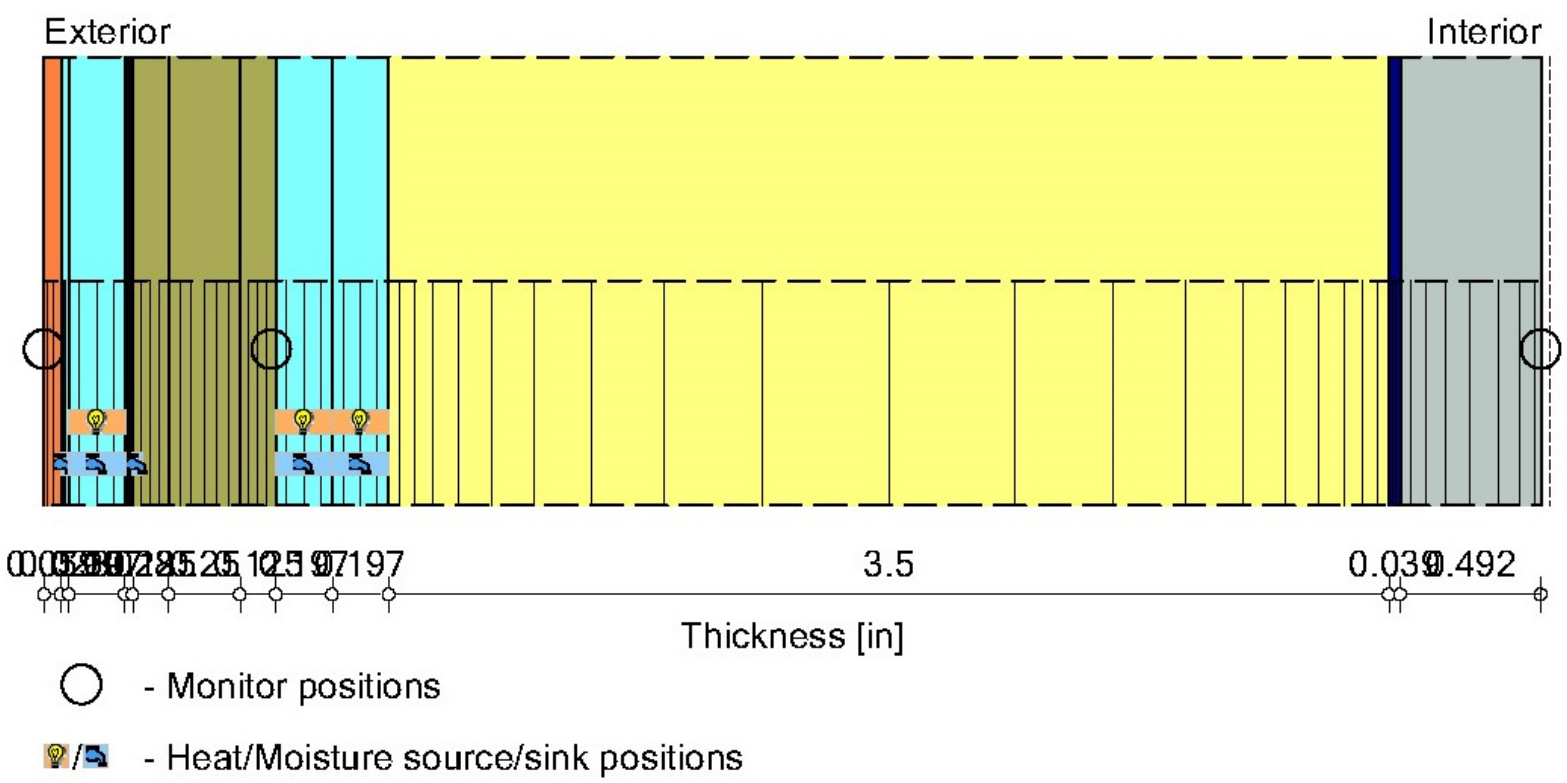

\section{Materials:}

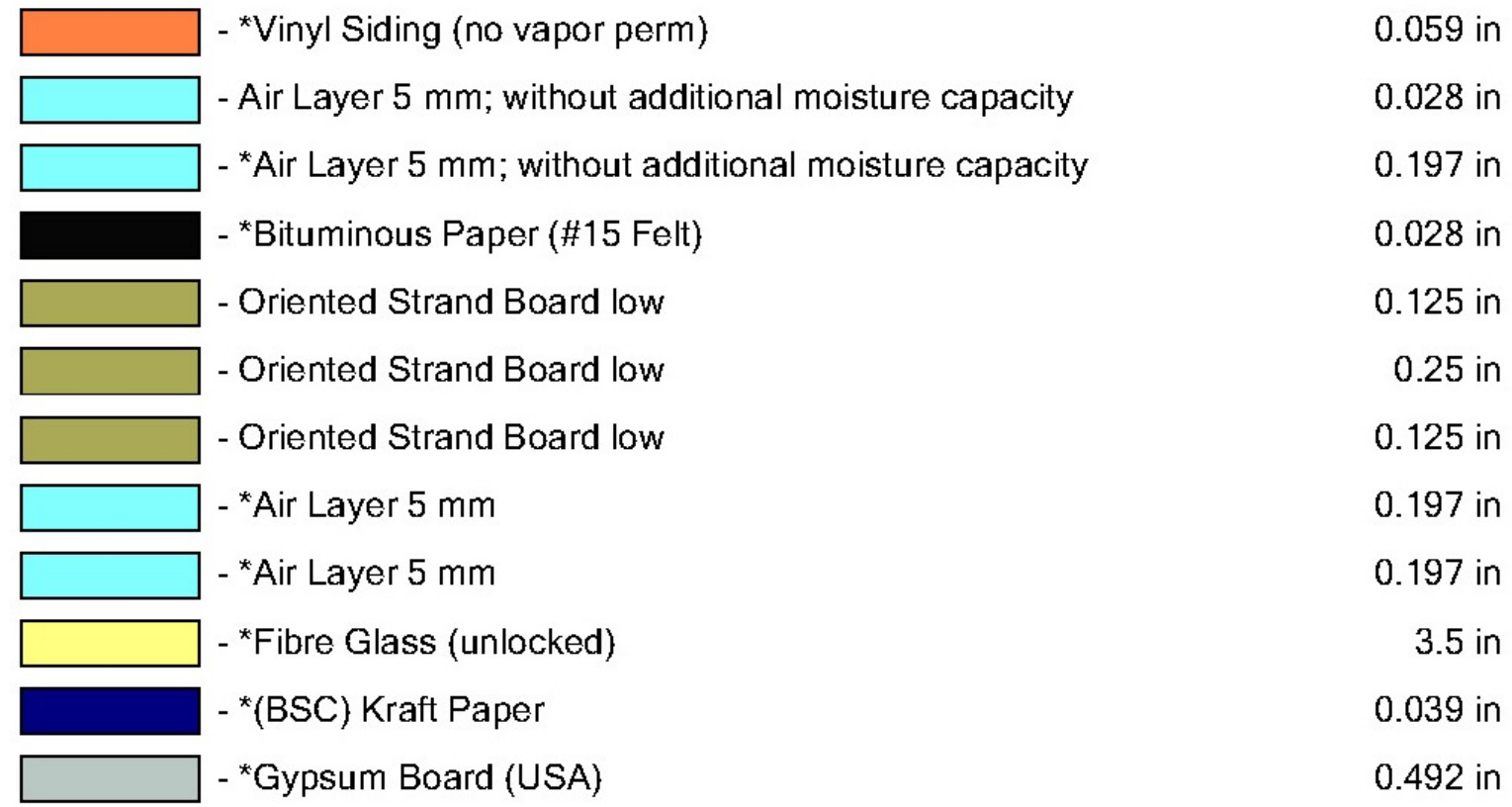

Sd-Value Int. [perm]: 10,0

Total Thickness: 5.24 in

R-Value: $17.69 \mathrm{~h} \mathrm{ft}^{2}{ }^{\circ} \mathrm{F} / \mathrm{Btu}$

U-Value: $0.053 \mathrm{Btu} / \mathrm{h} \mathrm{ft}{ }^{2 \circ} \mathrm{F}$ 


\section{Round 1, Wall 4 (Brick-OSB)}

Exterior
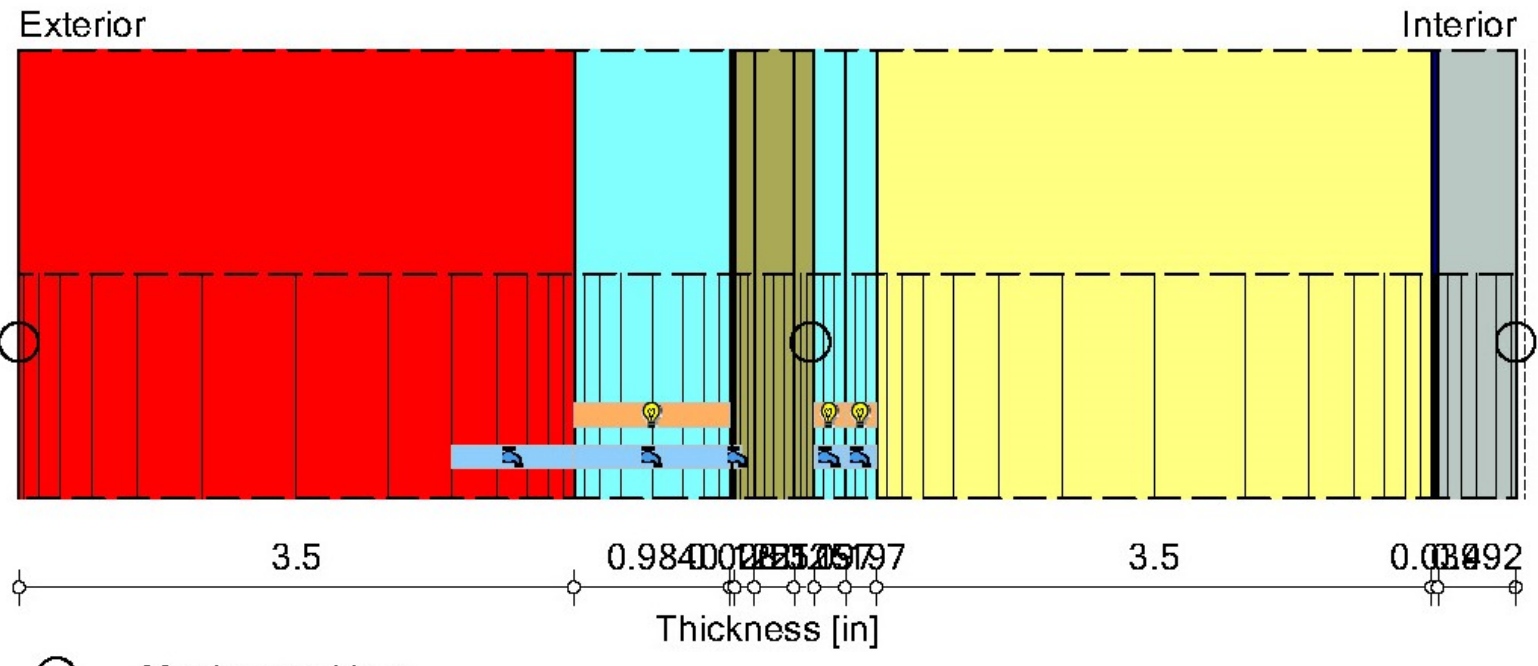

3.5

0.03992

- Monitor positions

(1/ - Heat/Moisture source/sink positions

\section{Materials:}

\begin{tabular}{|c|c|}
\hline - Solid Brick Masonry & 3.5 in \\
\hline - Air Layer 25 mm; without additional moisture capacity & 0.984 in \\
\hline - *Bituminous Paper (\#15 Felt) & 0.028 in \\
\hline - Oriented Strand Board low & 0.125 in \\
\hline - Oriented Strand Board low & 0.25 in \\
\hline - Oriented Strand Board low & 0.125 in \\
\hline - *Air Layer 5 mm & 0.197 in \\
\hline - *Air Layer 5 mm & 0.197 in \\
\hline - *Fibre Glass (unlocked) & $3.5 i$ \\
\hline - *(BSC) Kraft Paper & $0.039 i$ \\
\hline - *Gypsum Board (USA) & 0.492 \\
\hline
\end{tabular}

Sd-Value Int. [perm]: 10,0

Total Thickness: 9.44 in

R-Value: $18.6 \mathrm{~h} \mathrm{ft}^{2}{ }^{\circ} \mathrm{F} / \mathrm{Btu}$

U-Value: $0.051 \mathrm{Btu} / \mathrm{h} \mathrm{f{ } ^ { 2 } { } ^ { \circ } \mathrm { F }}$ 


\section{Round 1, Wall 5 (Stucco-OSB)}

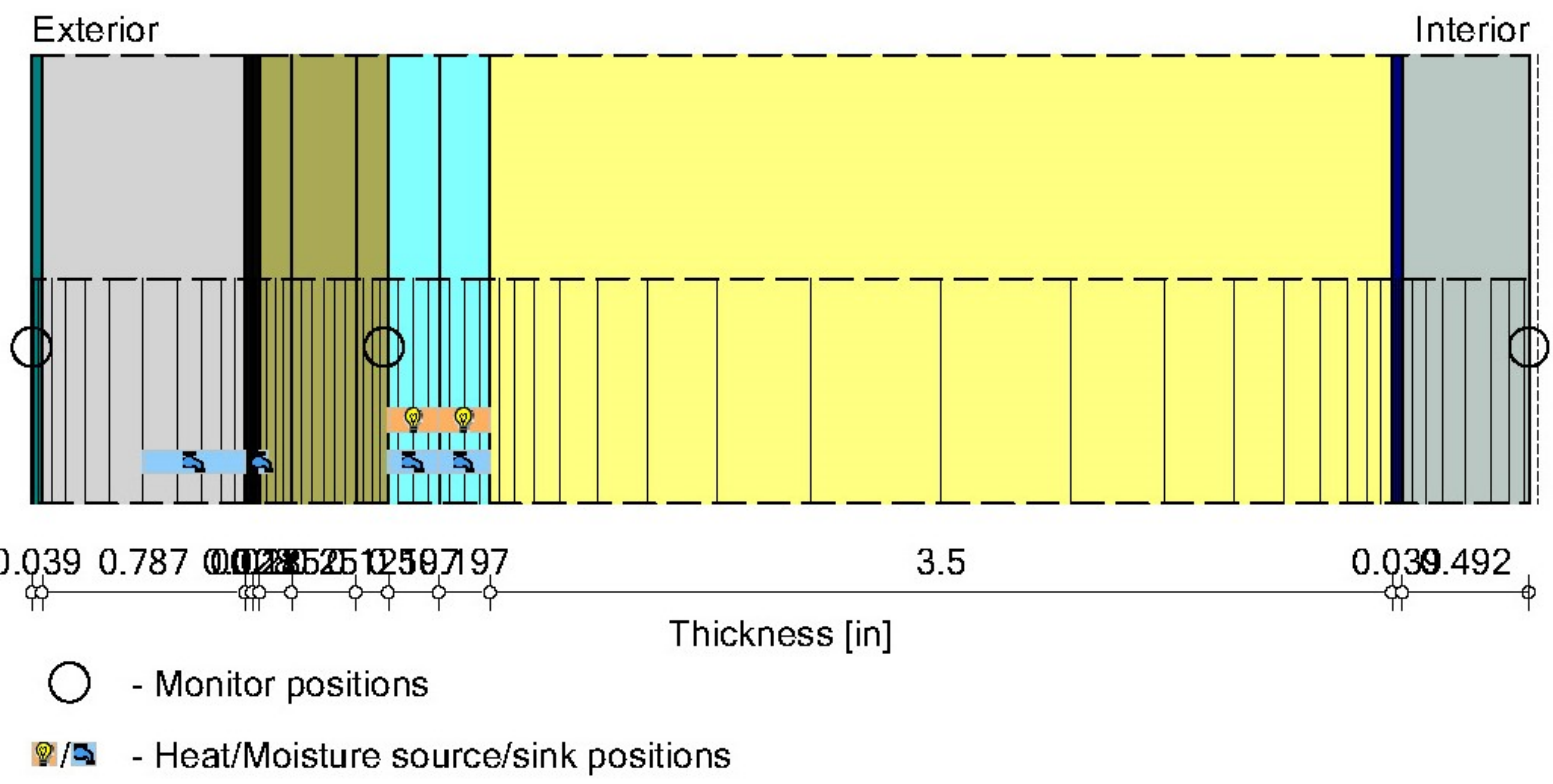

\section{Materials:}

\begin{tabular}{|c|c|}
\hline - *(BSC) Latex Paint \& Oil Primer for Wood Siding & 0.039 in \\
\hline - Regular Portland Stucco & 0.787 in \\
\hline - *Bituminous Paper (\#15 Felt) Outer & 0.028 in \\
\hline - *Bituminous Paper (\#15 Felt) Inner & 0.028 in \\
\hline - Oriented Strand Board low & 0.125 in \\
\hline - Oriented Strand Board low & $0.25 \mathrm{in}$ \\
\hline - Oriented Strand Board low & 0.125 in \\
\hline - *Air Layer 5 mm & 0.197 in \\
\hline - *Air Layer 5 mm & 0.197 in \\
\hline - *Fibre Glass (unlocked) & 3.5 in \\
\hline - *(BSC) Kraft Paper & $0.039 \mathrm{in}$ \\
\hline - *Gypsum Board (USA) & 0.492 \\
\hline
\end{tabular}

Sd-Value Int. [perm]: 10,0

Total Thickness: 5.81 in R-Value: $17.23 \mathrm{~h} \mathrm{ft}^{2}{ }^{\circ} \mathrm{F} / \mathrm{Btu}$ U-Value: $0.055 \mathrm{Btu} / \mathrm{h} \mathrm{ft}{ }^{2 \circ} \mathrm{F}$ 


\section{Round 1, Wall 6 (Vented Stucco-OSB)}

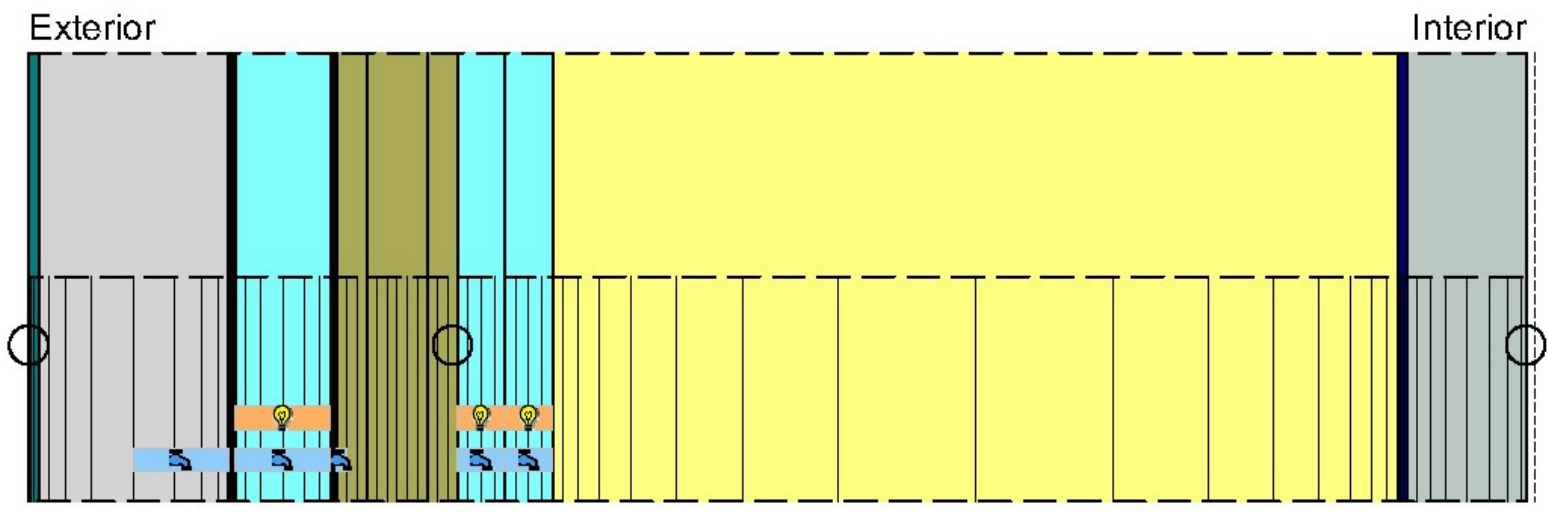

0.0390 .7870 .0083060285255 T2597797 3.5

Thickness [in]

- Monitor positions

(1/a - Heat/Moisture source/sink positions

\section{Materials:}

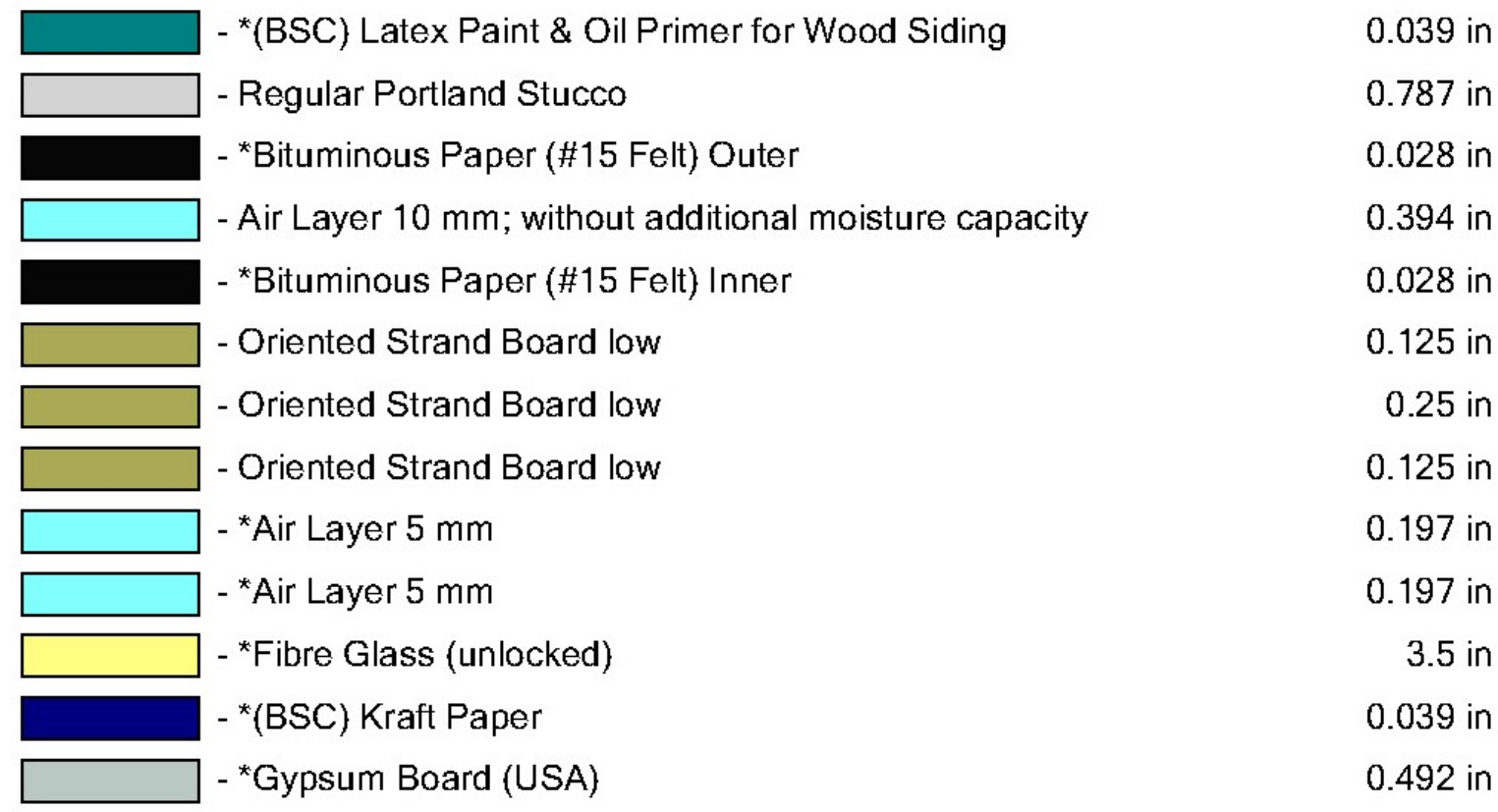

Sd-Value Int. [perm]: 10,0

Total Thickness: 6.2 in

R-Value: $18.04 \mathrm{~h} \mathrm{ft}^{2}{ }^{\circ} \mathrm{F} / \mathrm{Btu}$ U-Value: $0.052 \mathrm{Btu} / \mathrm{h} \mathrm{ft}^{2 \circ} \mathrm{F}$ 


\section{Round 2, Wall 1 (Wood Siding-Ply)}

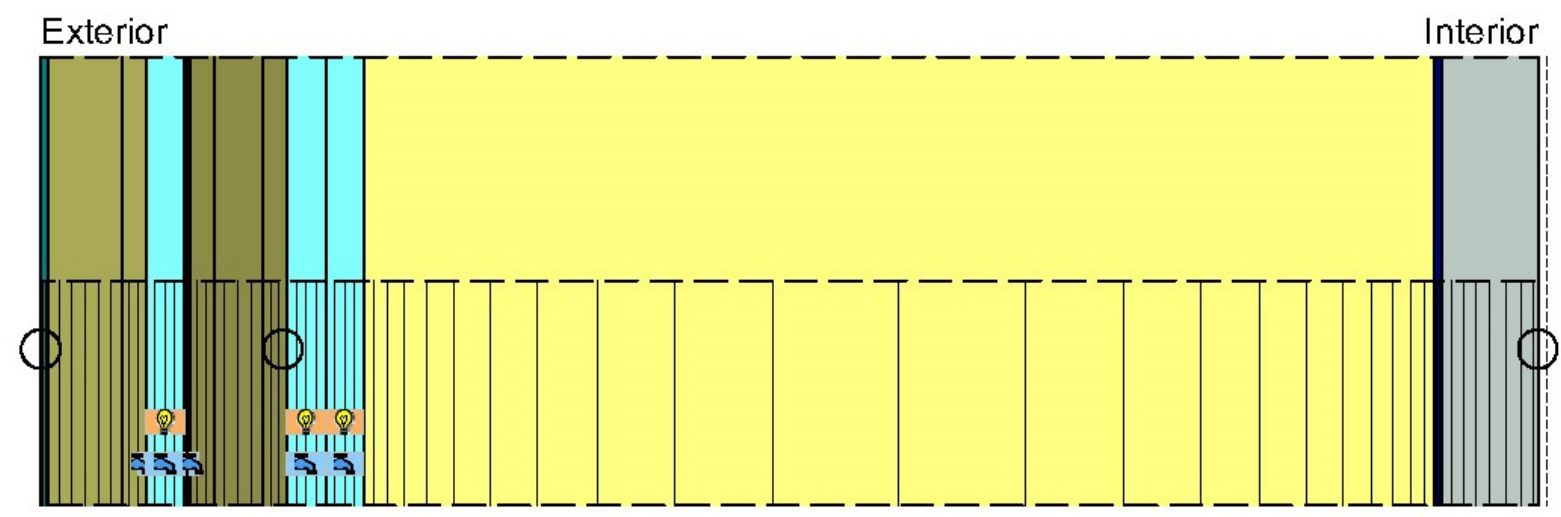

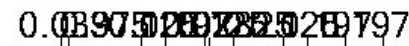
5.5

Thickness [in]

- Monitor positions

(1/ - Heat/Moisture source/sink positions

\section{Materials:}

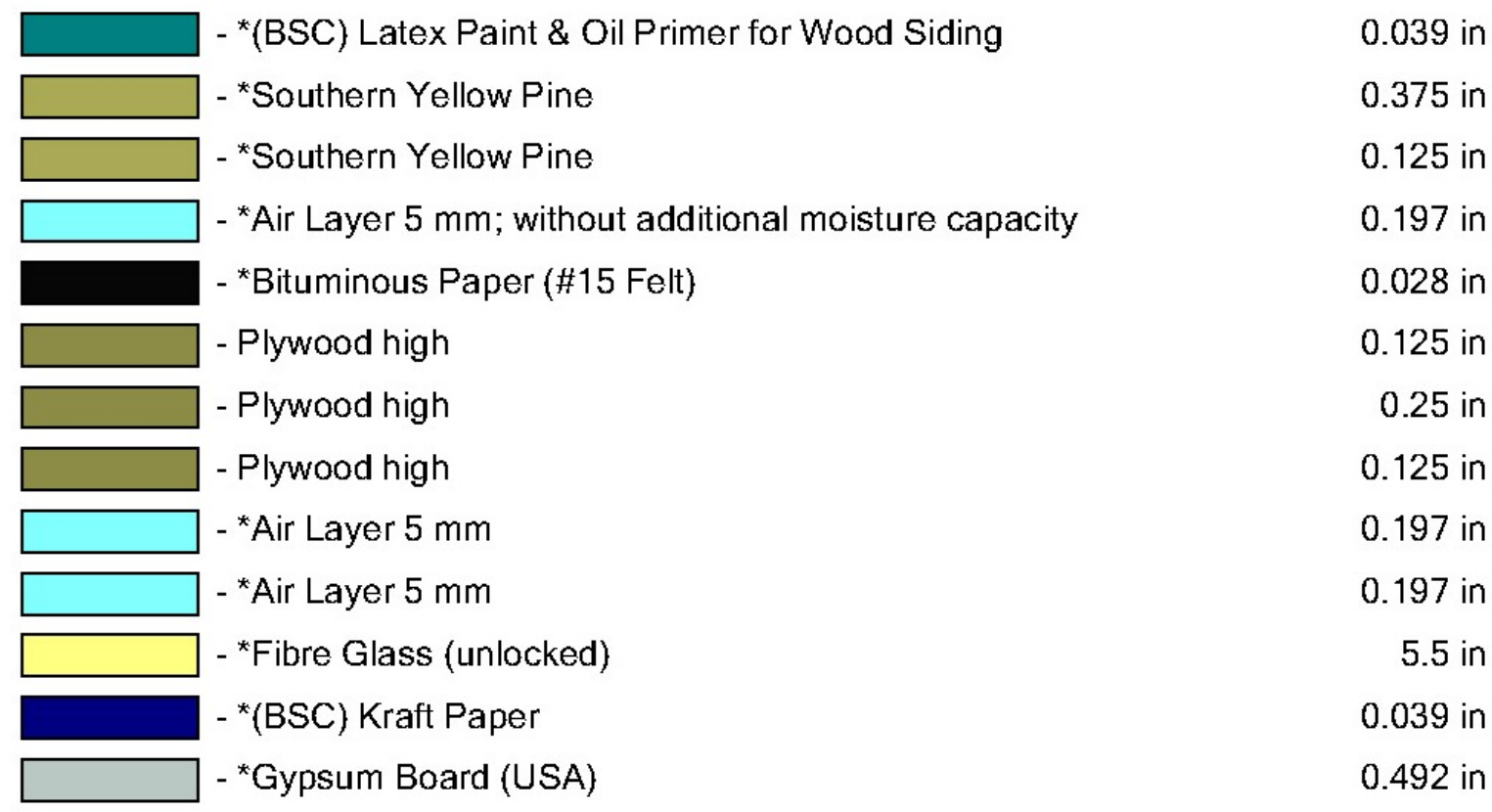

Sd-Value Int. [perm]: 10,0

Total Thickness: 7.69 in

R-Value: $26.29 \mathrm{~h} \mathrm{ft}^{2}{ }^{\circ} \mathrm{F} / \mathrm{Btu}$

U-Value: $0.037 \mathrm{Btu} / \mathrm{h} \mathrm{ft}{ }^{2 \circ} \mathrm{F}$ 


\section{Round 2, Wall 2 (Vinyl Siding-Ply)}
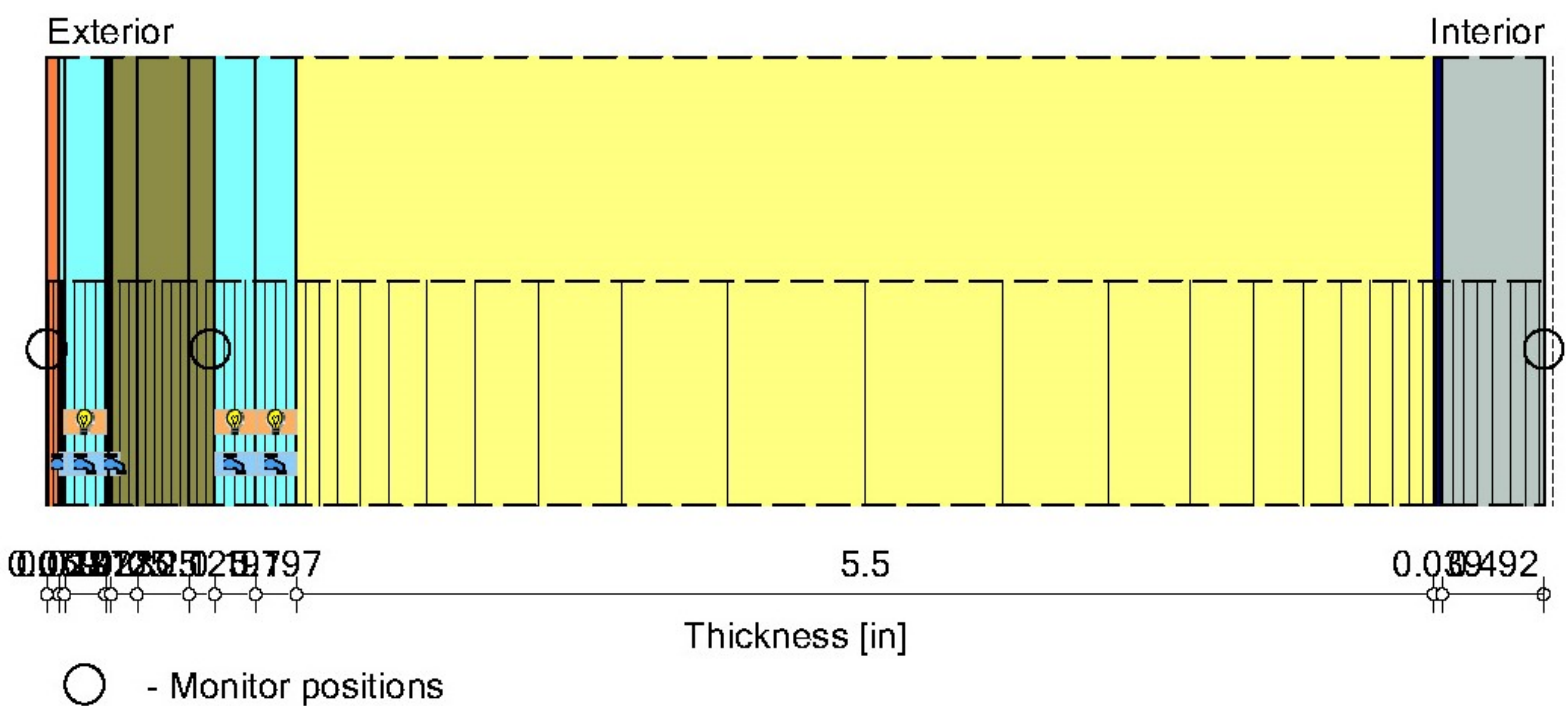

(1/ - Heat/Moisture source/sink positions

\section{Materials:}

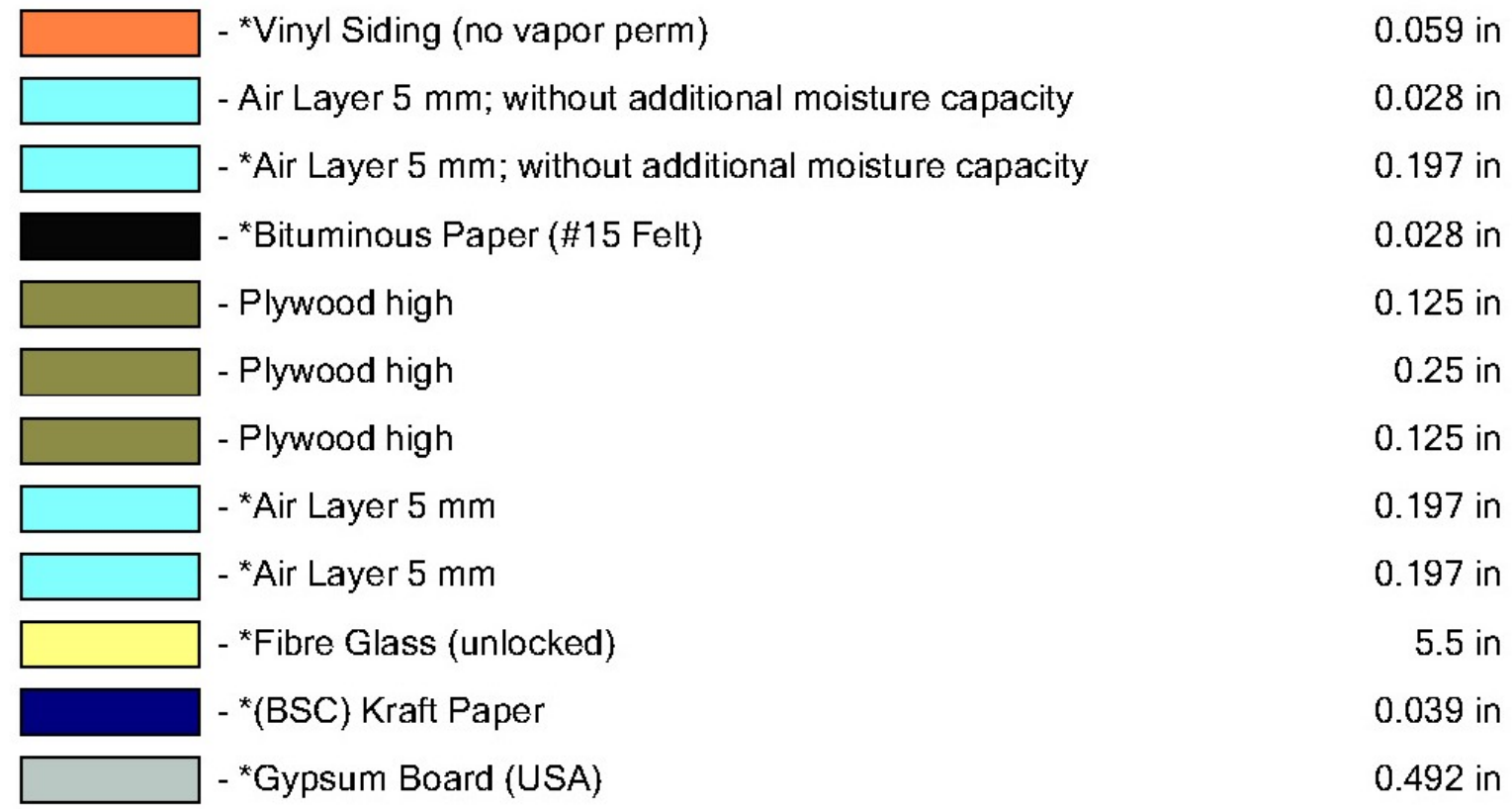

Sd-Value Int. [perm]: 10,0

Total Thickness: 7.24 in

R-Value: $25.82 \mathrm{~h} \mathrm{ft}^{2}{ }^{\circ} \mathrm{F} / \mathrm{Btu}$

U-Value: $0.037 \mathrm{Btu} / \mathrm{h} \mathrm{ft}^{20} \mathrm{~F}$ 


\section{Round 2, Wall 3 (Vinyl-OSB)}

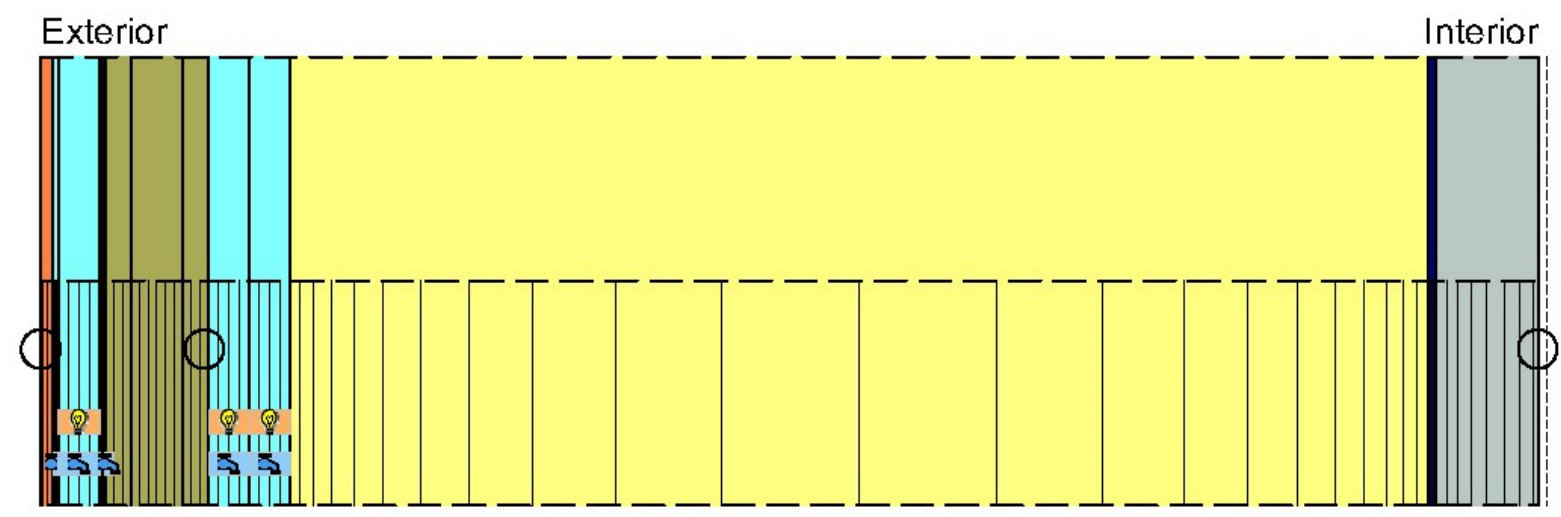

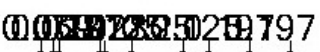

5.5

0.0 .09492

Thickness [in]

- Monitor positions

(1/ - Heat/Moisture source/sink positions

\section{Materials:}

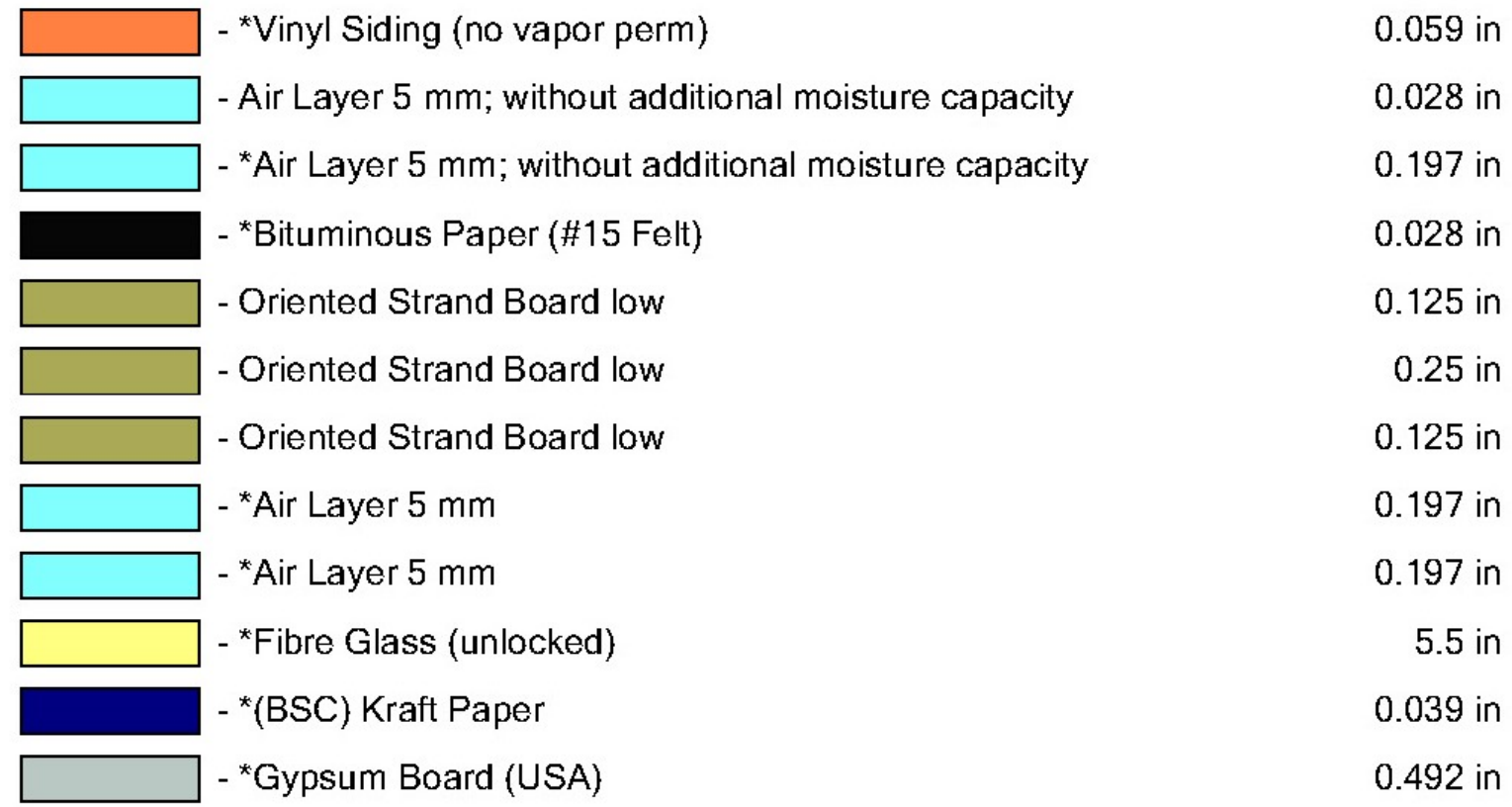

Sd-Value Int. [perm]: 10,0

Total Thickness: 7.24 in

R-Value: $25.95 \mathrm{~h} \mathrm{ft}^{2}{ }^{\circ} \mathrm{F} / \mathrm{Btu}$

U-Value: $0.037 \mathrm{Btu} / \mathrm{h} \mathrm{ft}{ }^{2 \circ} \mathrm{F}$ 


\section{Round 2, Wall 4 (Brick-OSB)}

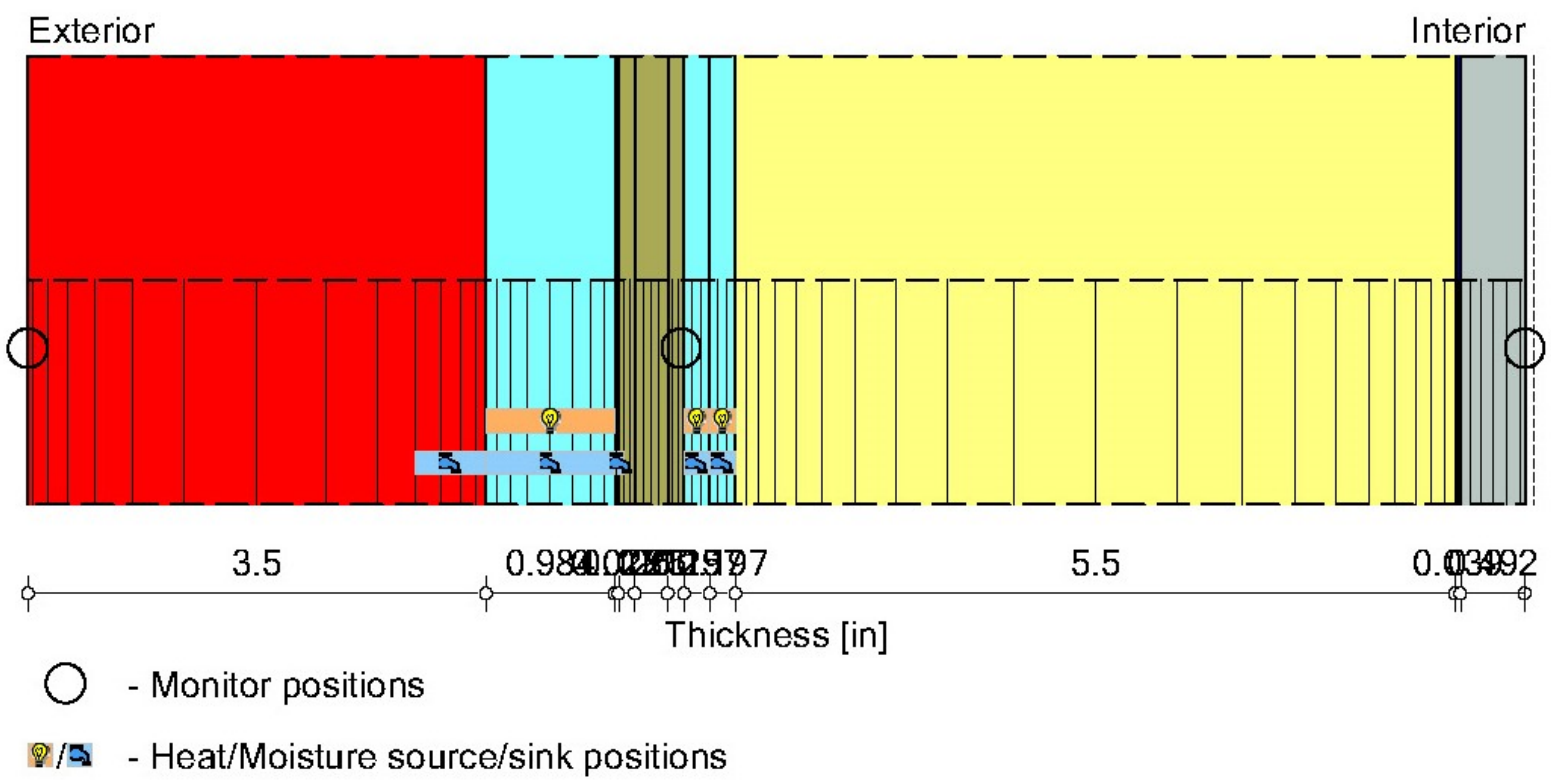

\section{Materials:}

\begin{tabular}{|c|c|}
\hline - Solid Brick Masonry & 3.5 in \\
\hline - Air Layer 25 mm; without additional moisture capacity & 0.984 in \\
\hline - *Bituminous Paper (\#15 Felt) & 0.028 in \\
\hline - Oriented Strand Board low & 0.125 in \\
\hline - Oriented Strand Board low & 0.25 in \\
\hline - Oriented Strand Board low & 0.125 in \\
\hline - *Air Layer 5 mm & 0.197 in \\
\hline - *Air Layer 5 mm & 0.197 in \\
\hline - *Fibre Glass (unlocked) & 5.5 in \\
\hline - *(BSC) Kraft Paper & 0.039 in \\
\hline - *Gypsum Board (USA) & 0.492 in \\
\hline
\end{tabular}

Sd-Value Int. [perm]: 10,0

Total Thickness: 11.44 in

R-Value: $26.85 \mathrm{~h} \mathrm{ft}^{2}{ }^{\circ} \mathrm{F} /$ Btu

U-Value: $0.036 \mathrm{Btu} / \mathrm{h} \mathrm{ft}^{2{ }^{\circ}} \mathrm{F}$ 


\section{Round 2, Wall 5 (Stucco-OSB)}

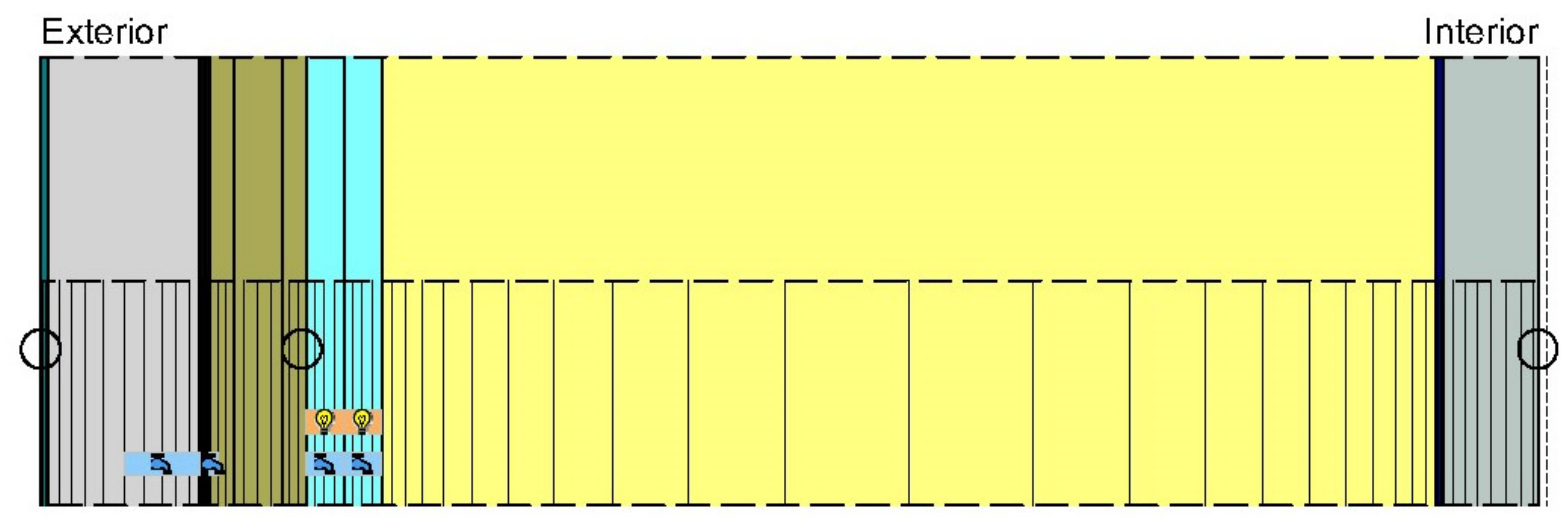

0.039 .7870002827029797

5.5

0.09992

- Monitor positions

ه/a - Heat/Moisture source/sink positions

\section{Materials:}

\begin{tabular}{|c|c|}
\hline - *(BSC) Latex Paint \& Oil Primer for Wood Siding & 0.039 in \\
\hline - Regular Portland Stucco & 0.787 in \\
\hline - *Bituminous Paper (\#15 Felt) Outer & 0.028 in \\
\hline - *Bituminous Paper (\#15 Felt) Inner & 0.028 in \\
\hline - Oriented Strand Board low & 0.125 in \\
\hline - Oriented Strand Board low & 0.25 in \\
\hline - Oriented Strand Board low & 0.125 in \\
\hline - *Air Layer 5 mm & 0.197 in \\
\hline - *Air Layer 5 mm & 0.197 in \\
\hline - *Fibre Glass (unlocked) & 5.5 in \\
\hline$-{ }^{*}$ (BSC) Kraft Paper & 0.039 in \\
\hline - *Gypsum Board (USA) & $0.492 i$ \\
\hline
\end{tabular}

Sd-Value Int. [perm]: 10,0

Total Thickness: 7.81 in

R-Value: $25.49 \mathrm{~h} \mathrm{ft}^{2}{ }^{\circ} \mathrm{F} /$ Btu

U-Value: $0.038 \mathrm{Btu} / \mathrm{h} \mathrm{ft}^{2{ }^{\circ}} \mathrm{F}$ 


\section{Round 2, Wall 6 (Vented Stucco-OSB)}

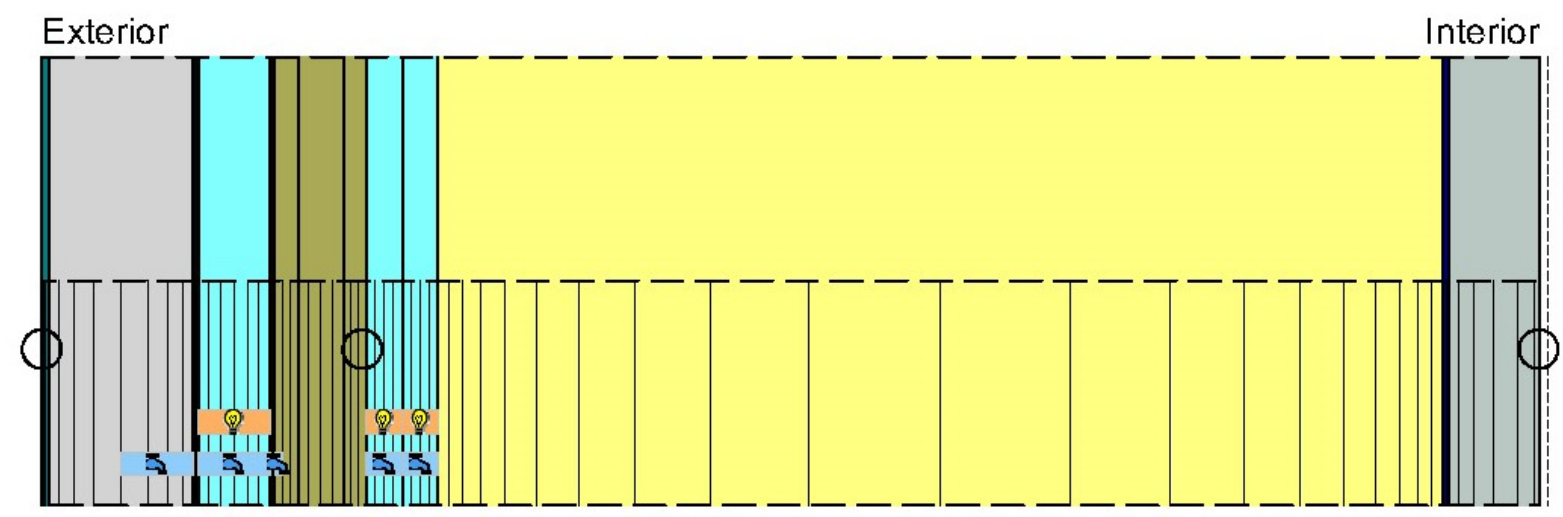

0.039 .780 .02890829259797

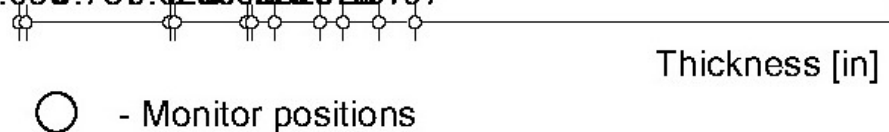

5.5

$0.099492_{\phi}$

(1/A - Heat/Moisture source/sink positions

\section{Materials:}

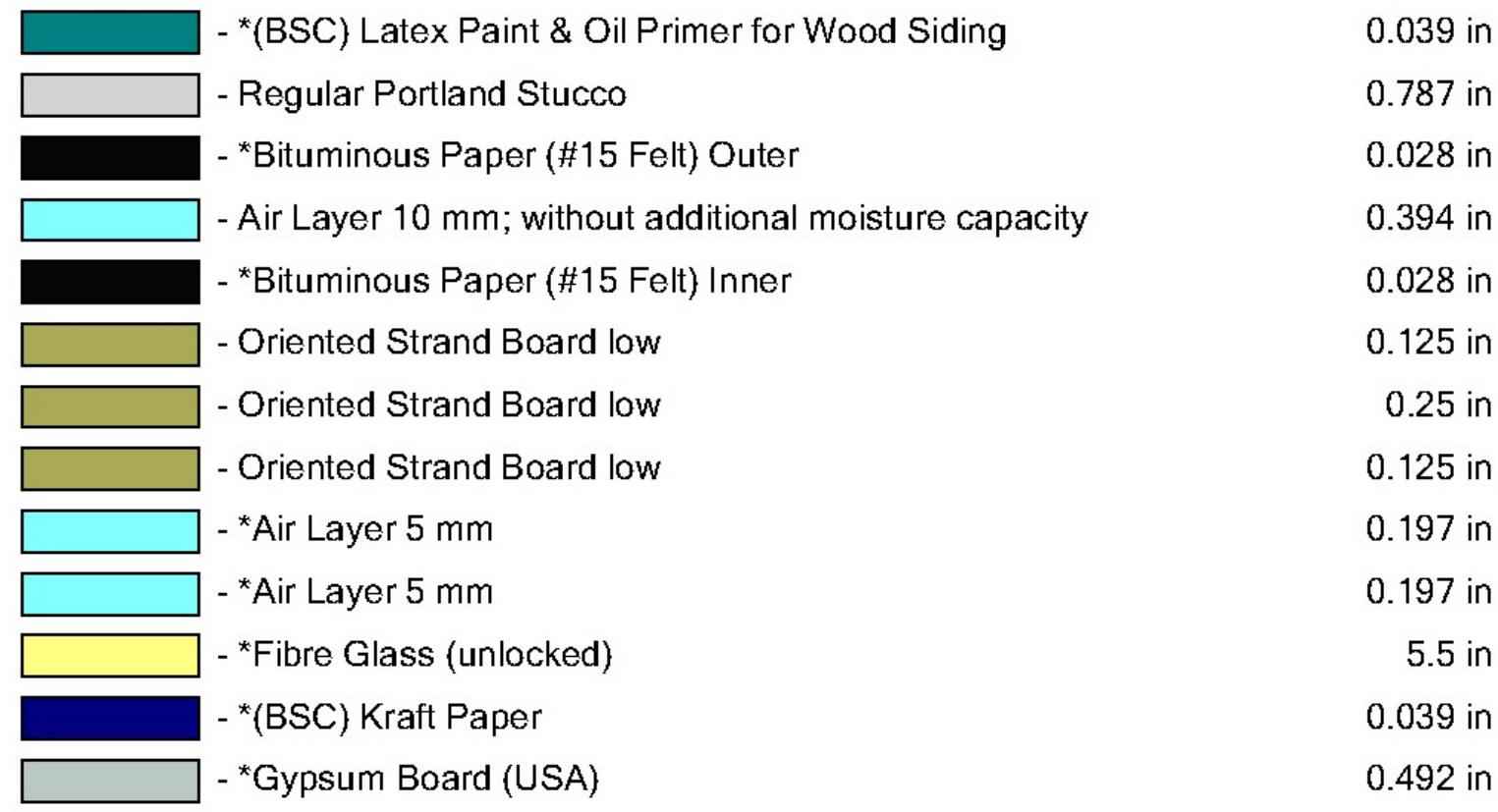

Sd-Value Int. [perm]: 10,0

Total Thickness: 8.2 in

R-Value: $26.29 \mathrm{~h} \mathrm{ft}^{2}{ }^{\circ} \mathrm{F} / \mathrm{Btu}$

U-Value: $0.037 \mathrm{Btu} / \mathrm{h} \mathrm{ft}^{2 \circ} \mathrm{F}$ 


\section{Round 3, Wall 1 (Wood Siding-Ply)}

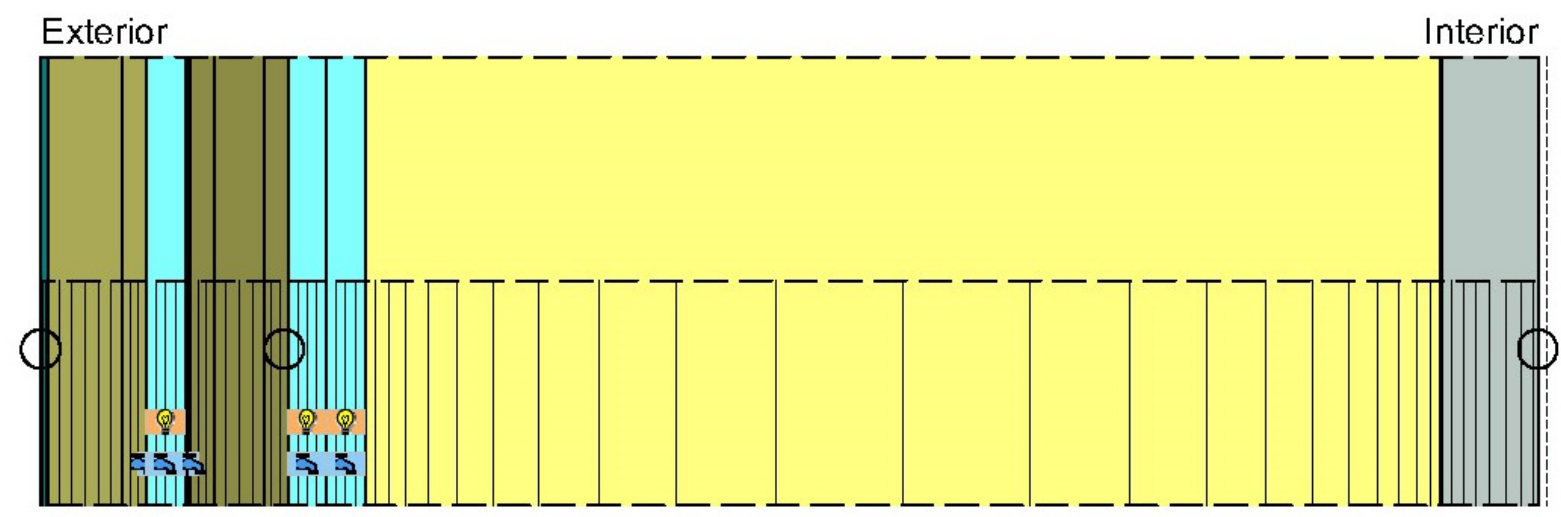

0.0390502696825218797 5.5

Thickness [in]

- Monitor positions

ه/a - Heat/Moisture source/sink positions

\section{Materials:}

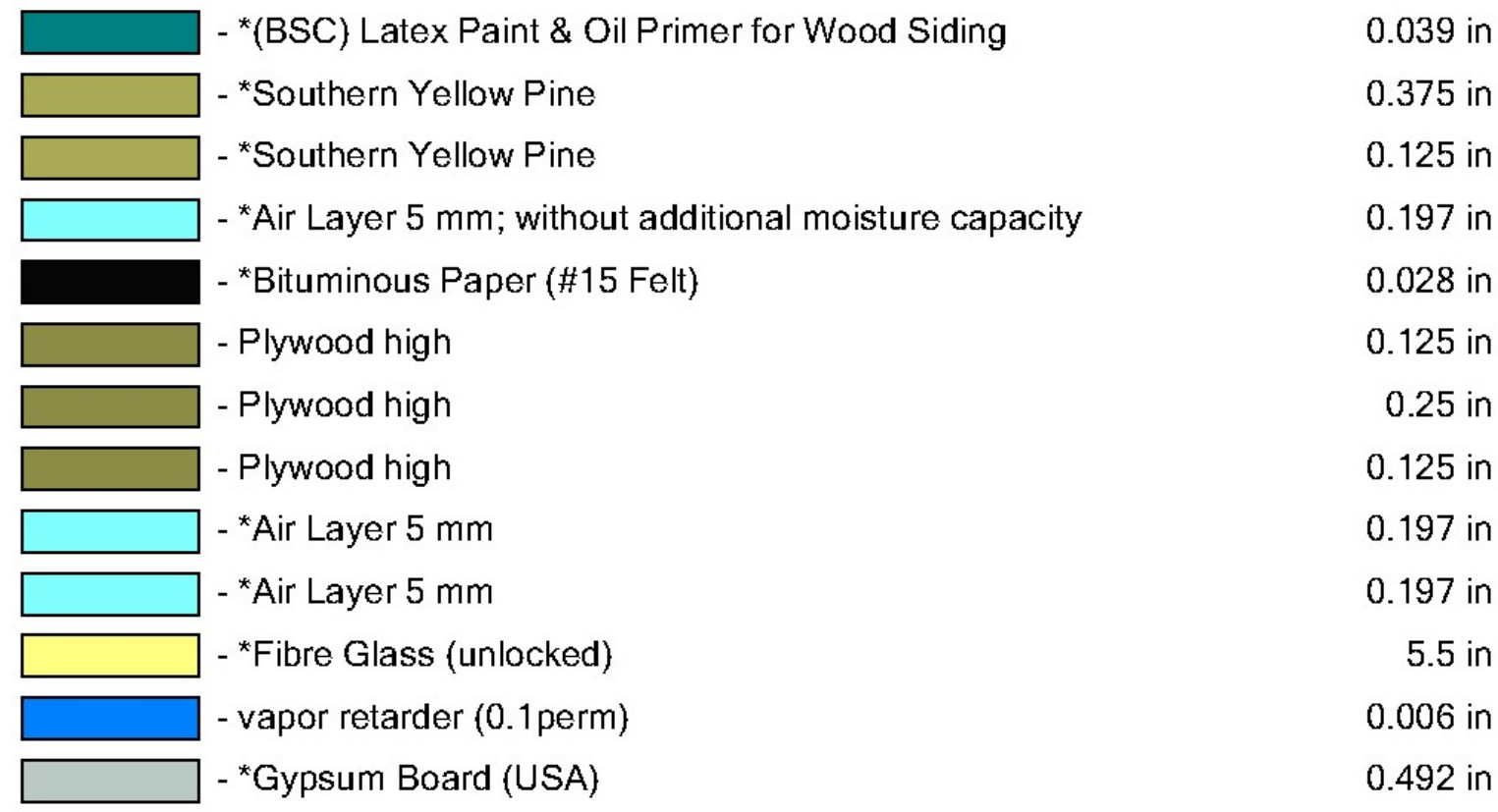

Sd-Value Int. [perm]: 10,0

Total Thickness: 7.66 in

R-Value: $26.28 \mathrm{~h} \mathrm{ft}^{2}{ }^{\circ} \mathrm{F} / \mathrm{Btu}$

U-Value: $0.037 \mathrm{Btu} / \mathrm{h} \mathrm{ft}{ }^{2 \circ} \mathrm{F}$ 


\section{Round 3, Wall 2 (Vinyl Siding-Ply)}

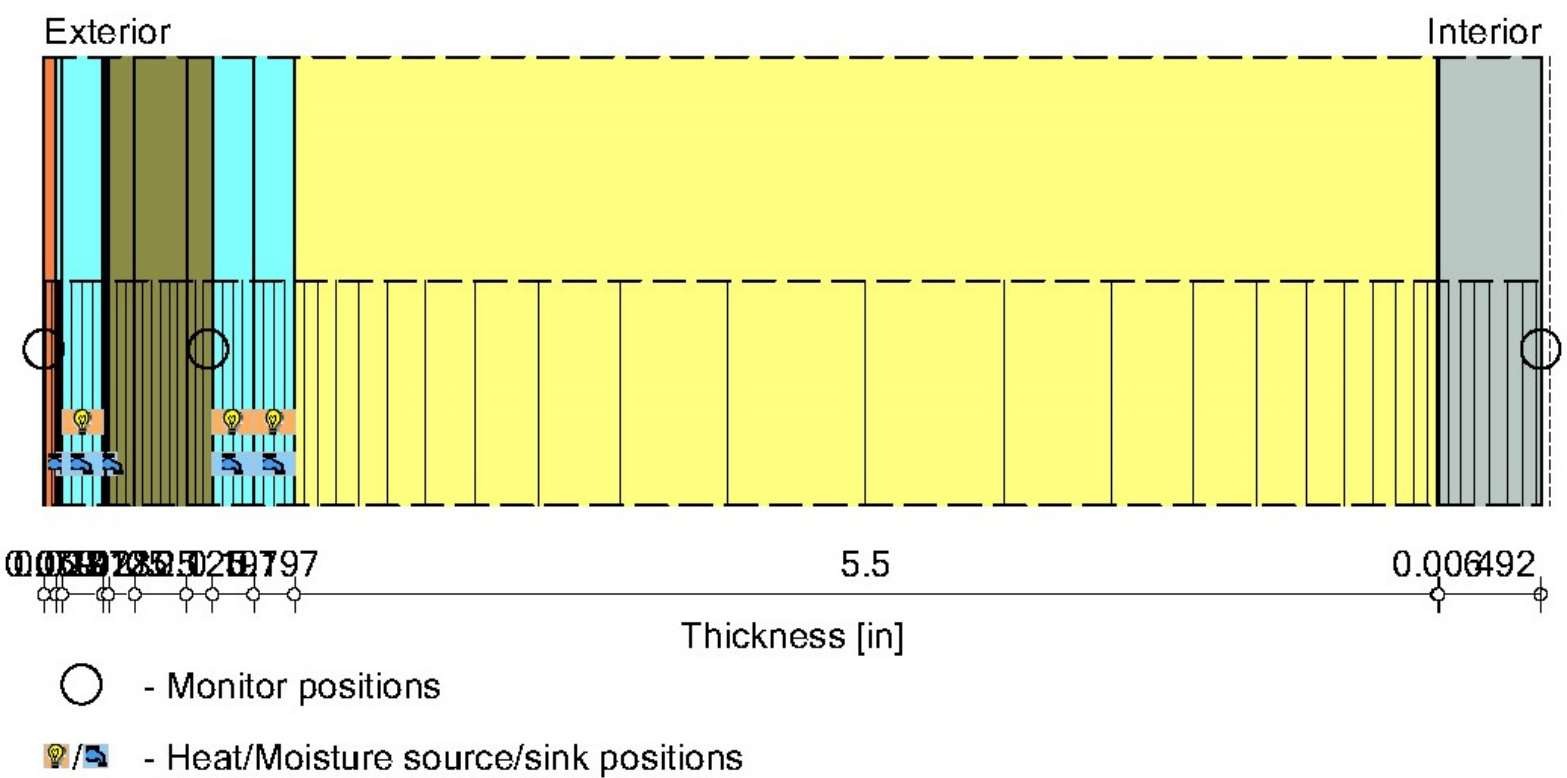

\section{Materials:}

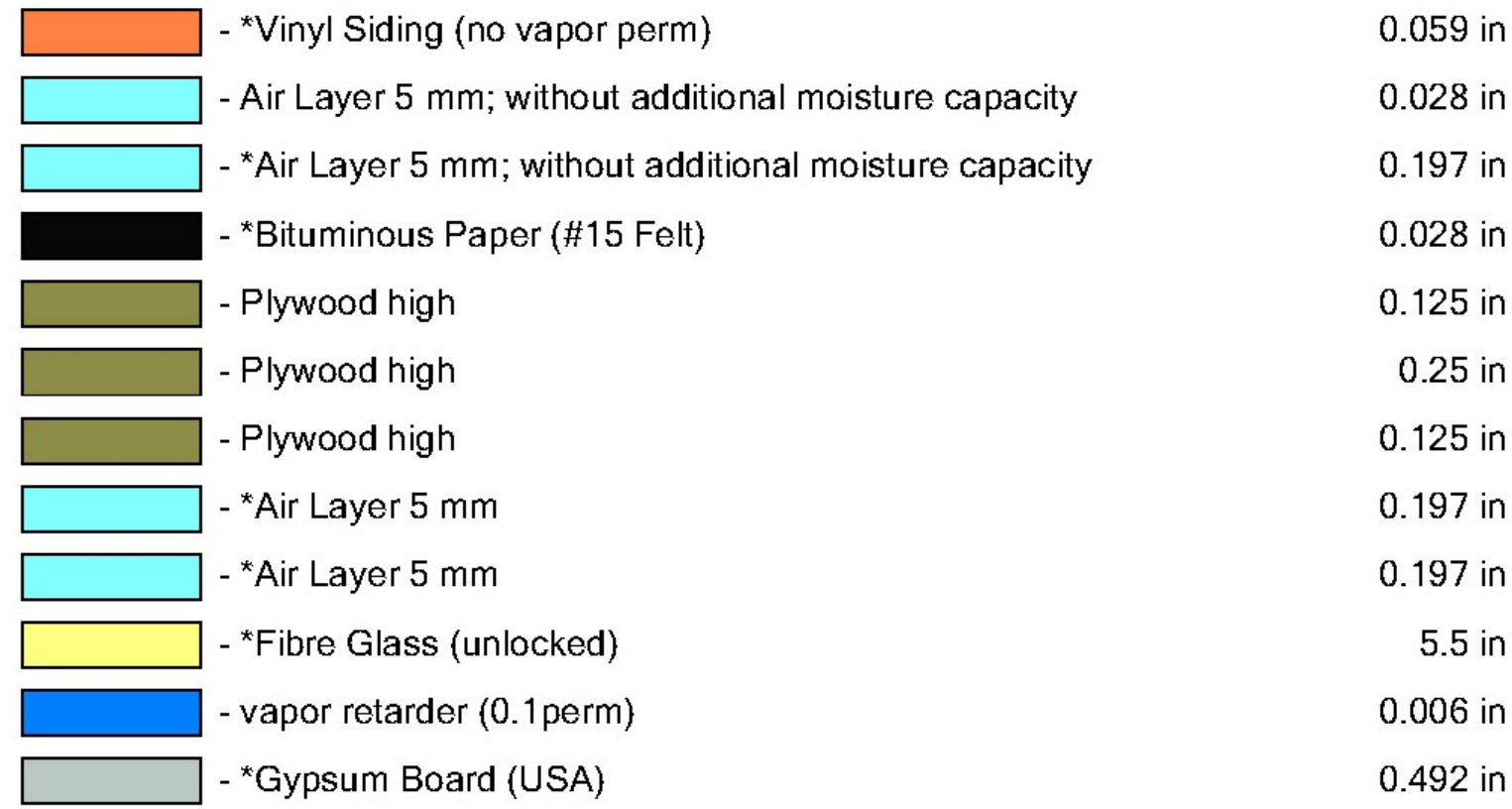

Sd-Value Int. [perm]: 10,0

Total Thickness: 7.2 in

R-Value: $25.8 \mathrm{~h} \mathrm{ft}^{2}{ }^{\circ} \mathrm{F} / \mathrm{Btu}$

U-Value: $0.037 \mathrm{Btu} / \mathrm{h} \mathrm{ft}^{2{ }^{\circ}} \mathrm{F}$ 


\section{Round 3, Wall 3 (Vinyl-OSB)}

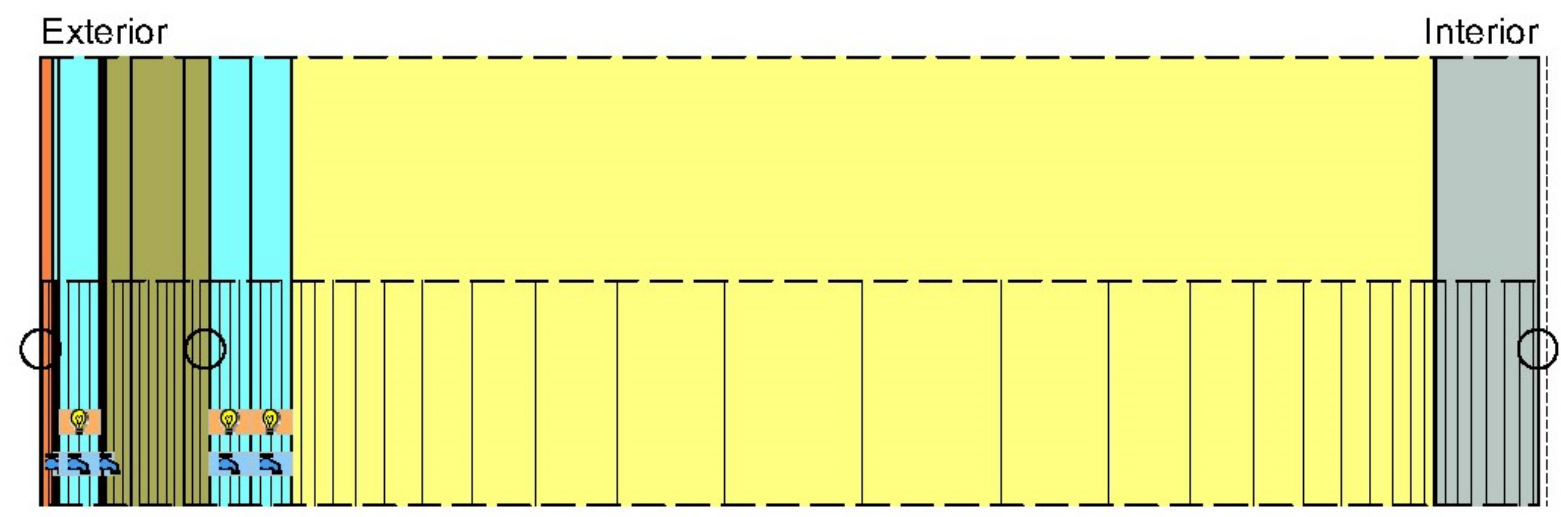

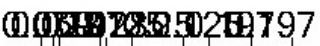

5.5

0.006492

Thickness [in]

- Monitor positions

(1/ - Heat/Moisture source/sink positions

\section{Materials:}

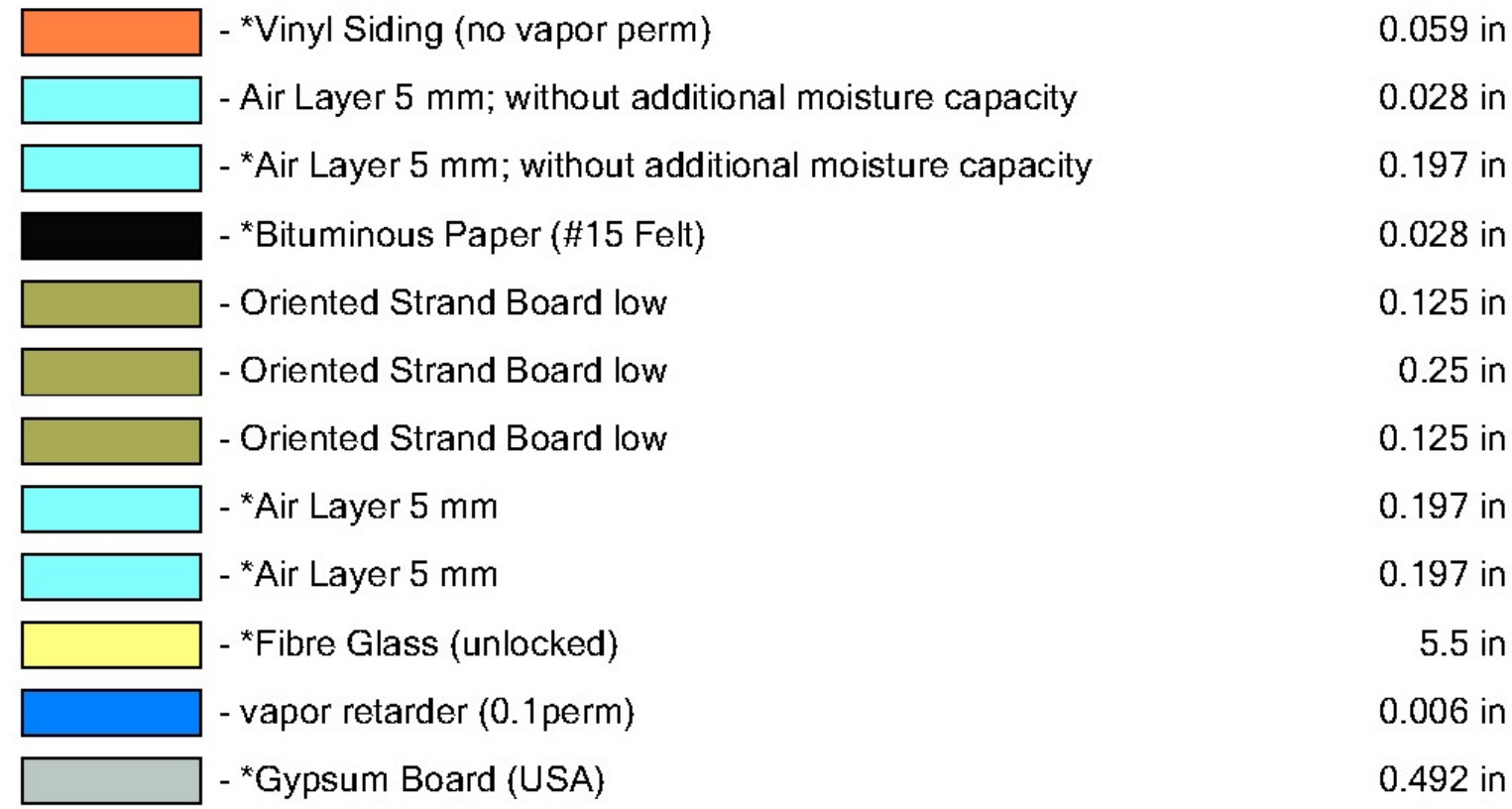

Sd-Value Int. [perm]: 10,0

Total Thickness: 7.2 in

R-Value: $25.94 \mathrm{~h} \mathrm{ft}^{2}{ }^{\circ} \mathrm{F} / \mathrm{Btu}$

U-Value: $0.037 \mathrm{Btu} / \mathrm{h} \mathrm{ft}^{2{ }^{\circ}} \mathrm{F}$ 


\section{Round 3, Wall 4 (Brick-OSB)}

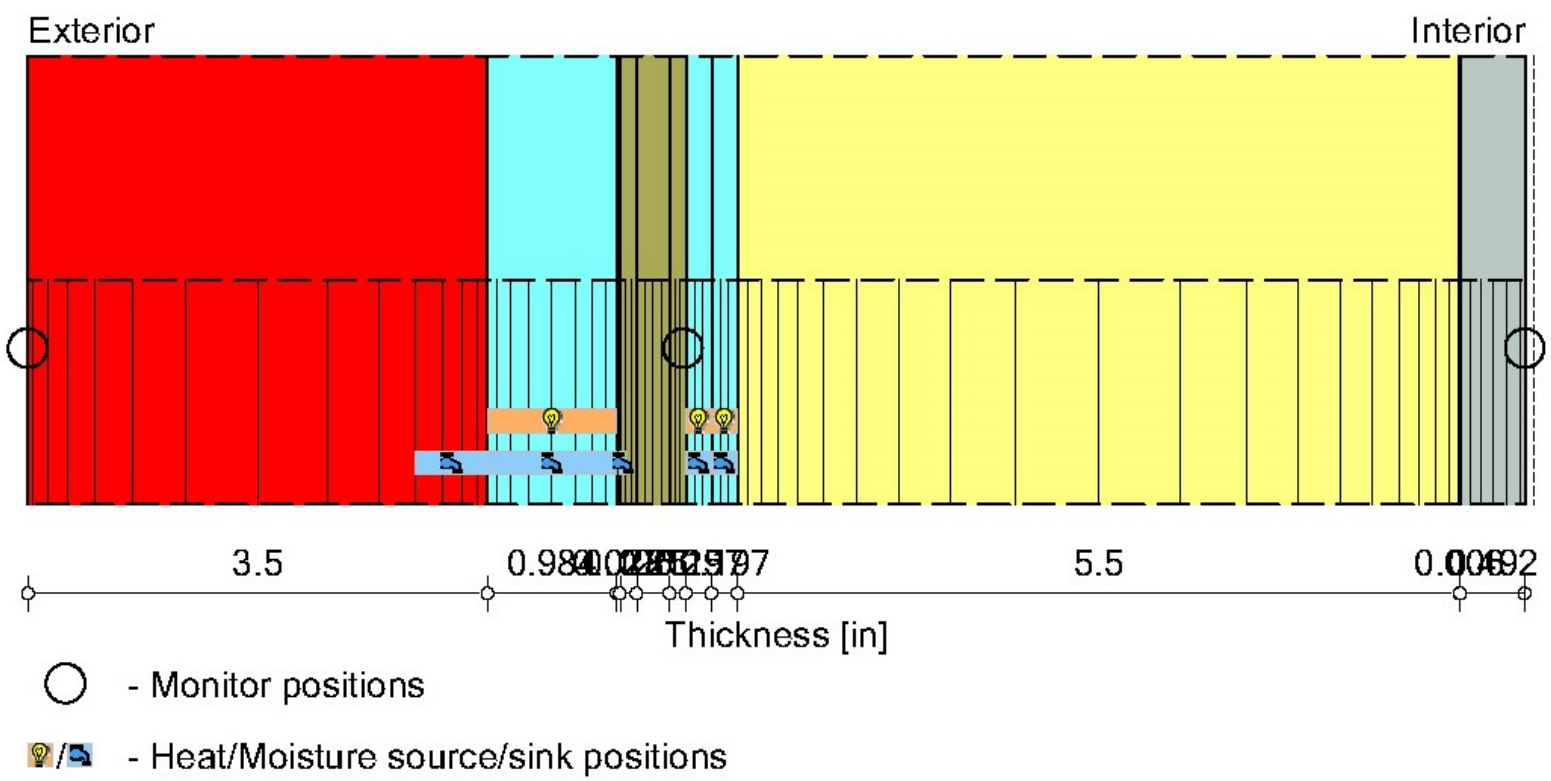

\section{Materials:}

\begin{tabular}{|c|c|}
\hline - Solid Brick Masonry & 3.5 in \\
\hline - Air Layer 25 mm; without additional moisture capacity & 0.984 in \\
\hline - *Bituminous Paper (\#15 Felt) & 0.028 in \\
\hline - Oriented Strand Board low & 0.125 in \\
\hline - Oriented Strand Board low & 0.25 in \\
\hline - Oriented Strand Board low & 0.125 in \\
\hline - *Air Layer 5 mm & 0.197 in \\
\hline - *Air Layer 5 mm & 0.197 in \\
\hline - *Fibre Glass (unlocked) & 5.5 in \\
\hline - vapor retarder $(0.1$ perm $)$ & 0.006 in \\
\hline - *Gypsum Board (USA) & $0.492 i$ \\
\hline
\end{tabular}

Sd-Value Int. [perm]: 10,0

Total Thickness: 11.4 in

R-Value: $26.84 \mathrm{~h} \mathrm{ft}^{2}{ }^{\circ} \mathrm{F} /$ Btu

U-Value: $0.036 \mathrm{Btu} / \mathrm{h} \mathrm{ft}^{2{ }^{\circ}} \mathrm{F}$ 


\section{Round 3, Wall 5 (Stucco-OSB)}

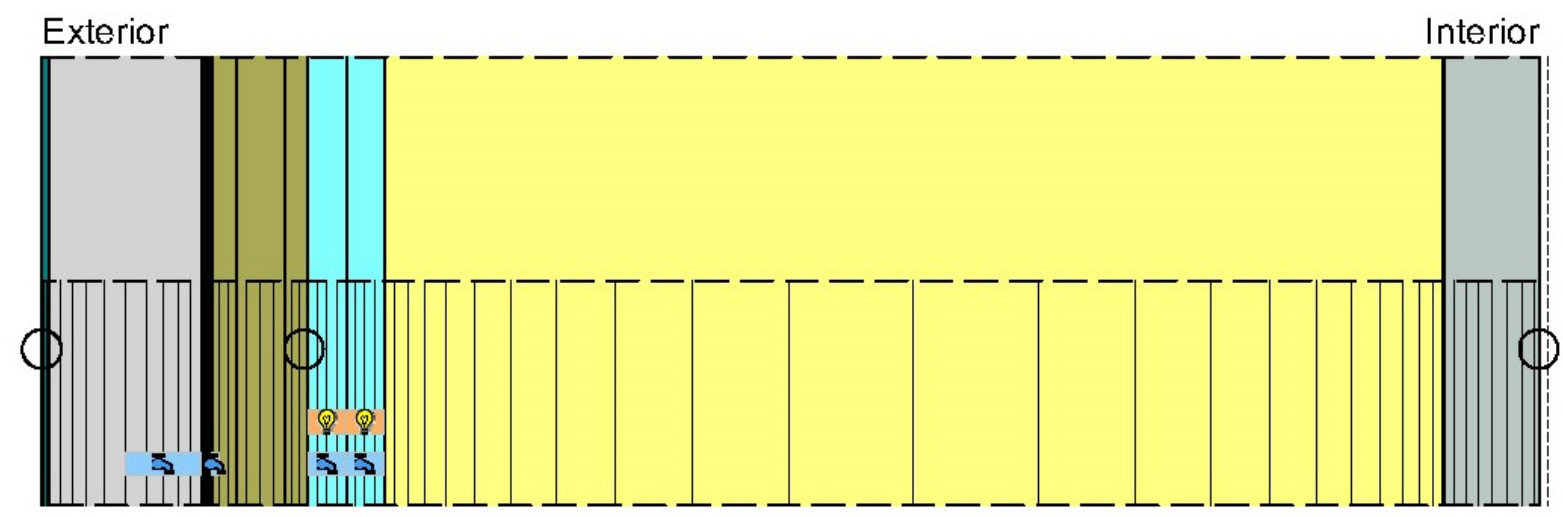

0.039 .78700020797

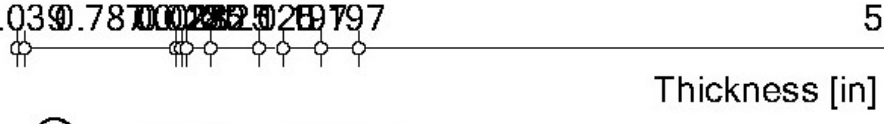

5.5

$0.00 \% 92$

- Monitor positions

(1/ - Heat/Moisture source/sink positions

\section{Materials:}

\begin{tabular}{|c|c|}
\hline - *(BSC) Latex Paint \& Oil Primer for Wood Siding & 0.039 in \\
\hline - Regular Portland Stucco & 0.787 in \\
\hline - *Bituminous Paper (\#15 Felt) Outer & 0.028 in \\
\hline - *Bituminous Paper (\#15 Felt) Inner & 0.028 in \\
\hline - Oriented Strand Board low & 0.125 in \\
\hline - Oriented Strand Board low & 0.25 in \\
\hline - Oriented Strand Board low & 0.125 in \\
\hline - *Air Layer 5 mm & 0.197 in \\
\hline - *Air Layer 5 mm & 0.197 in \\
\hline - *Fibre Glass (unlocked) & 5.5 in \\
\hline - vapor retarder $(0.1$ perm $)$ & 0.006 in \\
\hline - *Gypsum Board (USA) & $0.492 i$ \\
\hline
\end{tabular}

Sd-Value Int. [perm]: 10,0

Total Thickness: 7.77 in

R-Value: $25.48 \mathrm{~h} \mathrm{ft}^{2}{ }^{\circ} \mathrm{F} / \mathrm{Btu}$

U-Value: $0.038 \mathrm{Btu} / \mathrm{h} \mathrm{ft}^{2{ }^{\circ}} \mathrm{F}$ 


\section{Round 3, Wall 6 (Vented Stucco-OSB)}

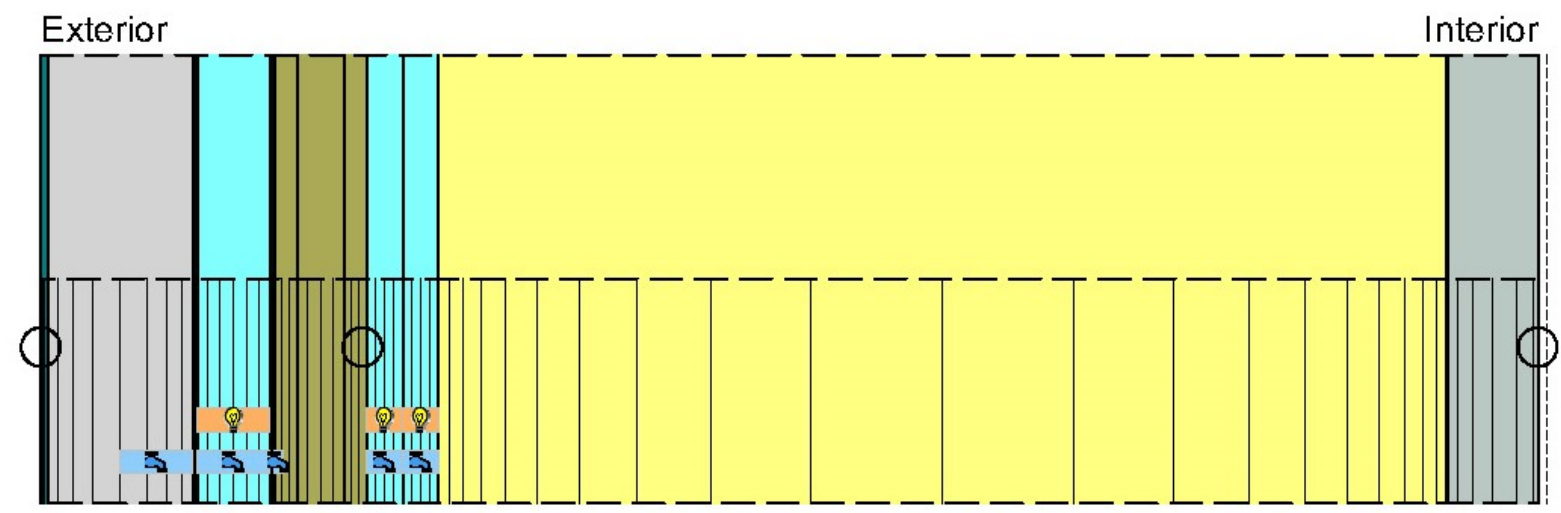

0.039 .780 .0289402525797

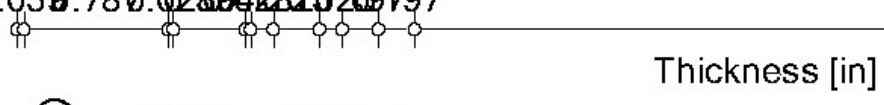

5.5

0.00692

- Monitor positions

(1/ - Heat/Moisture source/sink positions

\section{Materials:}

\begin{tabular}{|c|c|}
\hline - *(BSC) Latex Paint \& Oil Primer for Wood Siding & 0.039 in \\
\hline - Regular Portland Stucco & 0.787 in \\
\hline - *Bituminous Paper (\#15 Felt) Outer & 0.028 in \\
\hline - Air Layer $10 \mathrm{~mm}$; without additional moisture capacity & 0.394 in \\
\hline - *Bituminous Paper (\#15 Felt) Inner & 0.028 in \\
\hline - Oriented Strand Board low & 0.125 in \\
\hline - Oriented Strand Board low & 0.25 in \\
\hline - Oriented Strand Board low & 0.125 in \\
\hline - *Air Layer 5 mm & 0.197 in \\
\hline - *Air Layer 5 mm & 0.197 in \\
\hline - *Fibre Glass (unlocked) & 5.5 \\
\hline - vapor retarder (0.1perm) & 0.006 in \\
\hline - *Gypsum Board (USA) & 0.492 in \\
\hline
\end{tabular}

Sd-Value Int. [perm]: 10,0

Total Thickness: 8.17 in

R-Value: $26.28 \mathrm{~h} \mathrm{ft}^{2}{ }^{\circ} \mathrm{F} / \mathrm{Btu}$

U-Value: $0.037 \mathrm{Btu} / \mathrm{h} \mathrm{ft}{ }^{2 \circ} \mathrm{F}$ 


\section{Appendix B. WUFI Materials}

Material: *(BSC) Latex Paint \& Oil Primer for Wood Siding

Checking Input Data

\begin{tabular}{|l|c|c|}
\hline \multicolumn{1}{|c|}{ Property } & Unit & Value \\
\hline Bulk density & {$\left[\mathrm{lb} / \mathrm{ft}^{3}\right]$} & 8,116 \\
\hline Porosity & {$\left[\mathrm{ft}^{3} / \mathrm{ft}^{3}\right]$} & 0,001 \\
\hline Specific Heat Capacity, Dry & {$\left[\mathrm{Btu} / \mathrm{b}^{\circ} \mathrm{F}\right]$} & 0,549 \\
\hline Thermal Conductivity, Dry, $50^{\circ} \mathrm{F}$ & {$\left[\mathrm{Btu} / \mathrm{h} \mathrm{ft}{ }^{\circ} \mathrm{F}\right]$} & 1,329 \\
\hline Permeability & {$[\mathrm{perm} \mathrm{in}]$} & 0,035 \\
\hline Temp-dep. Thermal Cond. Supplement & {$\left[\mathrm{Btu} / \mathrm{h} \mathrm{ft}^{\circ} \mathrm{F}^{2}\right]$} & 0.0000640 \\
\hline
\end{tabular}
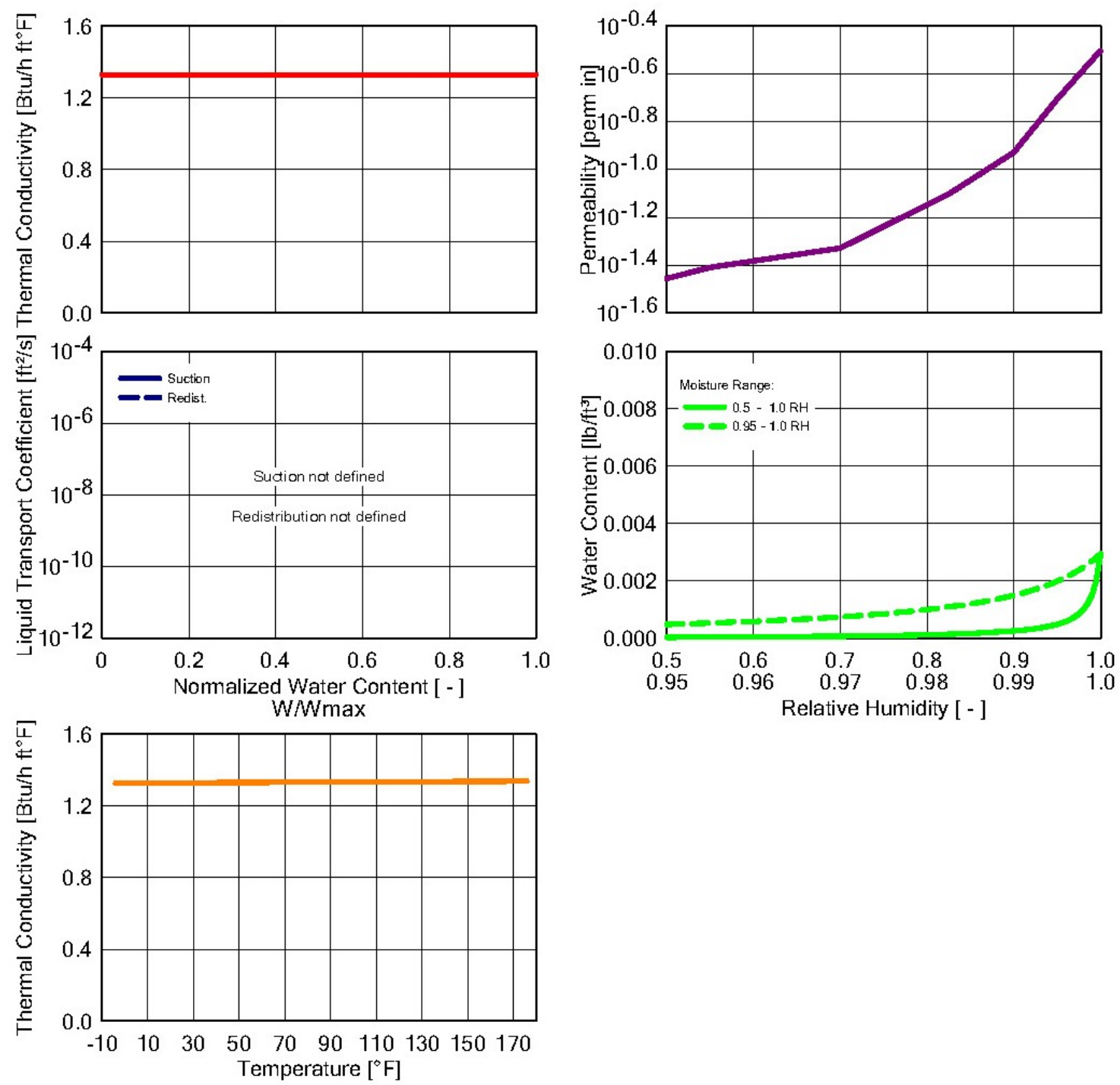
Material: *Southern Yellow Pine

Checking Input Data

\begin{tabular}{|l|c|c|}
\hline \multicolumn{1}{|c|}{ Property } & Unit & Value \\
\hline Bulk density & {$\left[\mathrm{lb} / \mathrm{ft}^{3}\right]$} & 31,214 \\
\hline Porosity & {$\left[\mathrm{ft}^{3} / \mathrm{ft}^{3}\right]$} & 0,858 \\
\hline Specific Heat Capacity, Dry & {$\left[\mathrm{Btu} / \mathrm{b}^{\circ} \mathrm{F}\right]$} & 0,449 \\
\hline Thermal Conductivity, Dry, 50 ${ }^{\circ} \mathrm{F}$ & {$\left[\mathrm{Btu} / \mathrm{h} \mathrm{ft}{ }^{\circ} \mathrm{F}\right]$} & 0,069 \\
\hline Permeability & {$[\mathrm{perm}$ in] } & 0,074 \\
\hline Reference Water Content & {$\left[\mathrm{lb} / \mathrm{ft}^{3}\right]$} & 3,883 \\
\hline Free Water Saturation & {$\left[\mathrm{lb} / \mathrm{ft}^{3}\right]$} & 18,728 \\
\hline Water Absorption Coefficient & {$\left[\mathrm{b} / \mathrm{in}^{2} \mathrm{~s}^{\wedge} 0.5\right]$} & 0.0000020 \\
\hline Temp-dep. Thermal Cond. Supplement & {$\left[\mathrm{Btu} / \mathrm{h} \mathrm{ft}{ }^{\circ} \mathrm{F}^{2}\right]$} & 0.0000640 \\
\hline
\end{tabular}
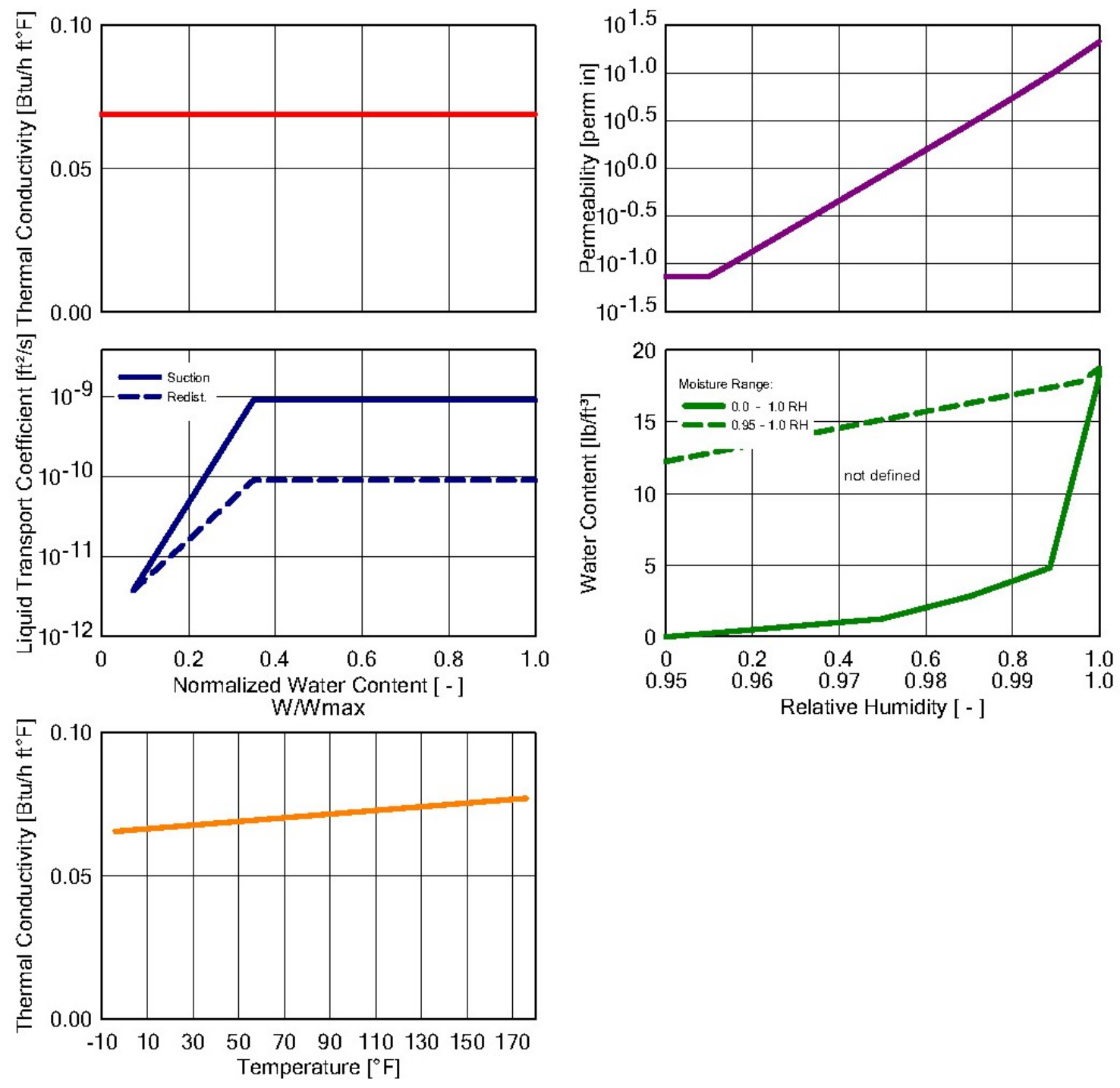
Material: *Vinyl Siding (no vapor perm)

Checking Input Data

\begin{tabular}{|l|c|c|}
\hline \multicolumn{1}{|c|}{ Property } & Unit & Value \\
\hline Bulk density & {$\left[\mathrm{lb} / \mathrm{ft}^{3}\right]$} & 51.753 \\
\hline Porosity & {$\left[\mathrm{ft}^{3} / \mathrm{ft}^{3}\right]$} & 0.001 \\
\hline Specific Heat Capacity, Dry & {$\left[\mathrm{Btu} / \mathrm{b}^{\circ} \mathrm{F}\right]$} & 0.549 \\
\hline Thermal Conductivity, Dry, $50^{\circ} \mathrm{F}$ & {$\left[\mathrm{Btu} / \mathrm{h} \mathrm{ft}{ }^{\circ} \mathrm{F}\right]$} & 0.098 \\
\hline Permeability & {$[\mathrm{perm}$ in] } & 0.001 \\
\hline Temp-dep. Thermal Cond. Supplement & {$\left[\mathrm{Btu} / \mathrm{h} \mathrm{ft}^{\circ} \mathrm{F}^{2}\right]$} & 0.000064 \\
\hline
\end{tabular}
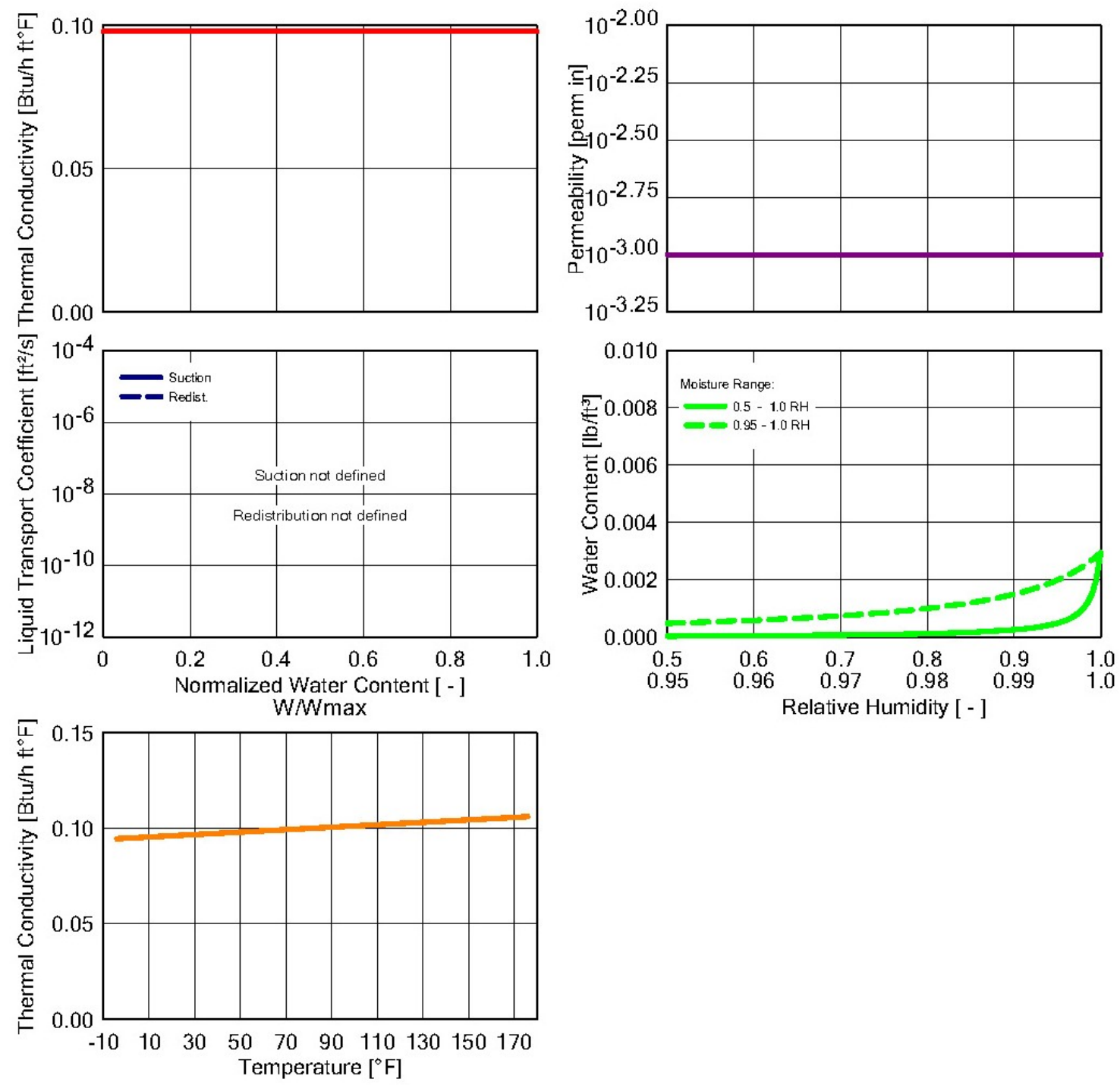
Material: Solid Brick Masonry

Checking Input Data

\begin{tabular}{|l|c|c|}
\hline \multicolumn{1}{|c|}{ Property } & Unit & Value \\
\hline Bulk density & {$\left[\mathrm{lb} / \mathrm{ft}^{3}\right]$} & 118.613 \\
\hline Porosity & {$\left[\mathrm{ft}^{3} / \mathrm{ft}^{3}\right]$} & 0.24 \\
\hline Specific Heat Capacity, Dry & {$\left[\mathrm{Btu} / \mathrm{b}^{\circ} \mathrm{F}\right]$} & 0.203 \\
\hline Thermal Conductivity, Dry, 50 ${ }^{\circ} \mathrm{F}$ & {$\left[\mathrm{Btu} / \mathrm{h} \mathrm{ft}{ }^{\circ} \mathrm{F}\right]$} & 0.347 \\
\hline Permeability & {$[\mathrm{perm}$ in] } & 12.88 \\
\hline Reference Water Content & {$\left[\mathrm{lb} / \mathrm{ft}^{3}\right]$} & 1.124 \\
\hline Free Water Saturation & {$\left[\mathrm{lb} / \mathrm{ft}^{3}\right]$} & 11.861 \\
\hline Moisture-dep. Thermal Cond. Supplement & {$[\% / \mathrm{M} .-\%]$} & 15.0 \\
\hline Temp-dep. Thermal Cond. Supplement & {$\left[\mathrm{Btu} / \mathrm{h} \mathrm{ft}{ }^{\circ} \mathrm{F}^{2}\right]$} & 0.000064 \\
\hline
\end{tabular}
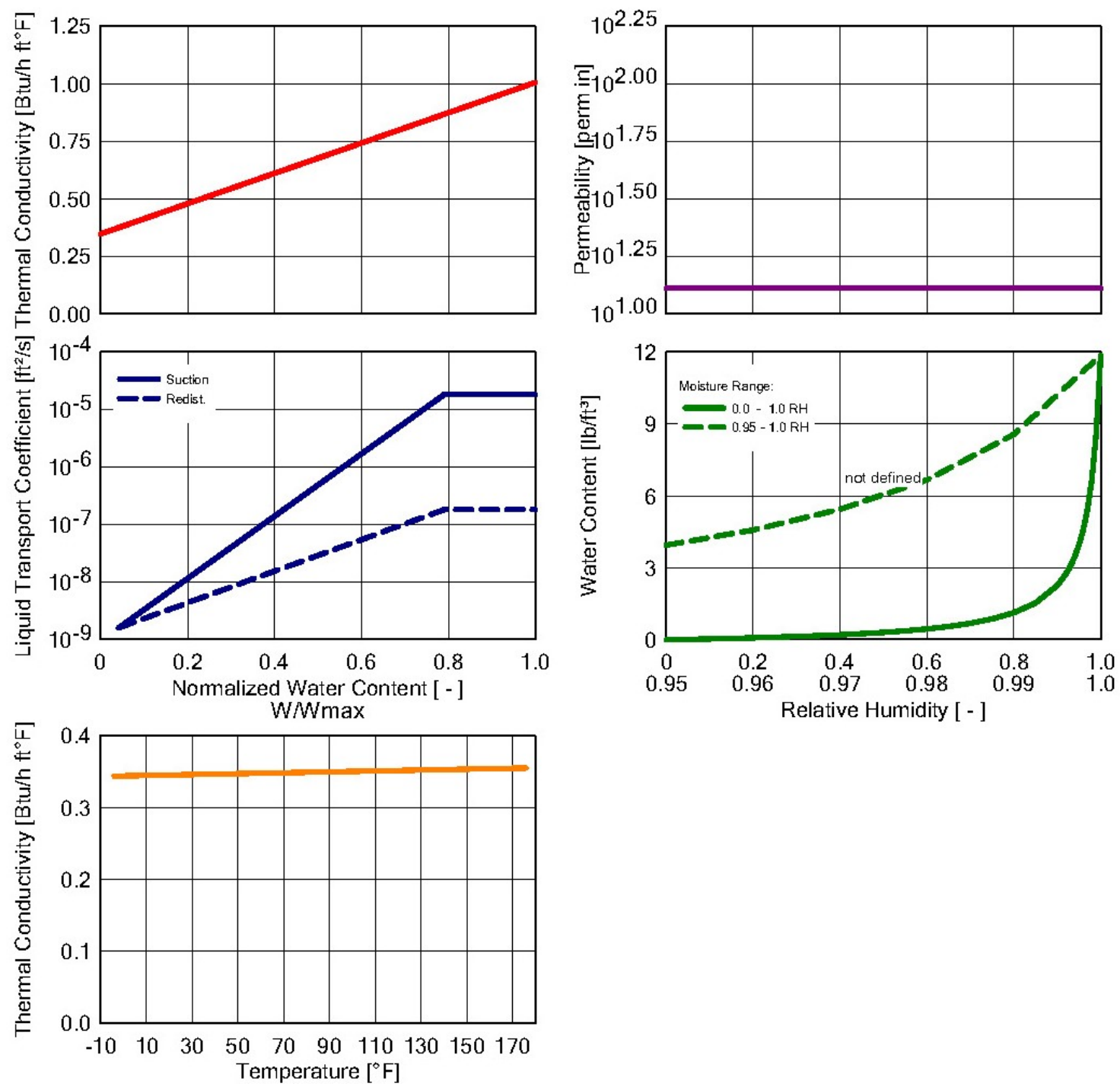


\section{Material: Regular Portland Stucco}

\section{Checking Input Data}

\begin{tabular}{|l|c|c|}
\hline \multicolumn{1}{|c|}{ Property } & Unit & Value \\
\hline Bulk density & {$\left[\mathrm{lb} / \mathrm{ft}^{3}\right]$} & 122.078 \\
\hline Porosity & {$\left[\mathrm{ft}^{3} / \mathrm{ft}^{3}\right]$} & 0.225 \\
\hline Specific Heat Capacity, Dry & {$\left[\mathrm{Btu} / \mathrm{b}^{\circ} \mathrm{F}\right]$} & 0.201 \\
\hline Thermal Conductivity, Dry, $50^{\circ} \mathrm{F}$ & {$\left[\mathrm{Btu} / \mathrm{h} \mathrm{ft}{ }^{\circ} \mathrm{F}\right]$} & 0.231 \\
\hline Permeability & {$[\mathrm{perm}$ in] } & 0.362 \\
\hline Temp-dep. Thermal Cond. Supplement & {$\left[\mathrm{Btu} / \mathrm{h} \mathrm{ft}^{\circ} \mathrm{F}^{2}\right]$} & 0.000064 \\
\hline
\end{tabular}
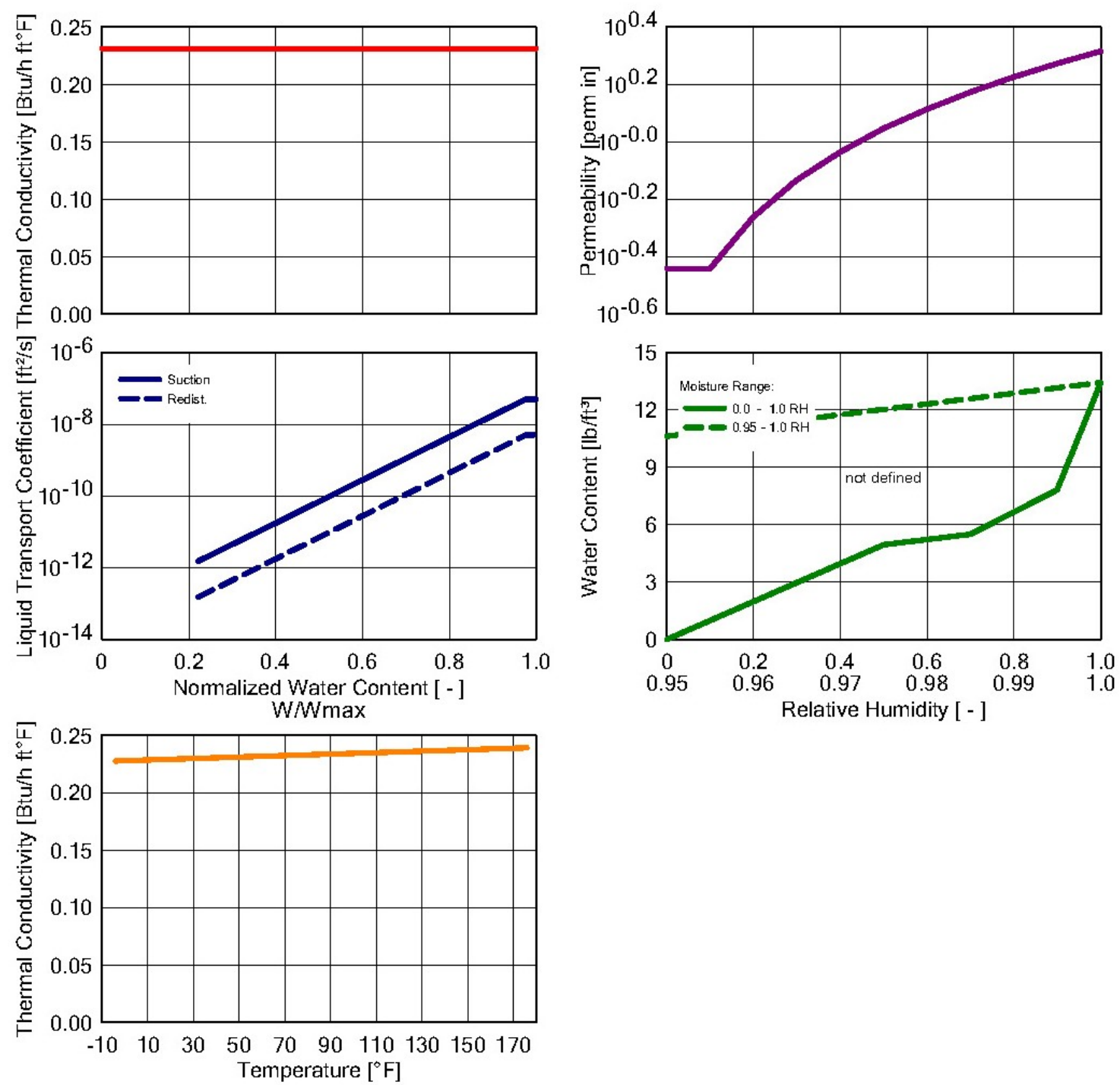
Material: *Air Layer $5 \mathrm{~mm}$; without additional moisture capacity

Checking Input Data

\begin{tabular}{|l|c|c|}
\hline \multicolumn{1}{|c|}{ Property } & Unit & Value \\
\hline Bulk density & {$\left[\mathrm{lb} / \mathrm{ft}^{3}\right]$} & 0,081 \\
\hline Porosity & {$\left[\mathrm{ft}^{3} / \mathrm{ft}^{3}\right]$} & 0,999 \\
\hline Specific Heat Capacity, Dry & {$\left[\mathrm{Btu} / \mathrm{b}^{\circ} \mathrm{F}\right]$} & 0,239 \\
\hline Thermal Conductivity, Dry, $50^{\circ} \mathrm{F}$ & {$\left[\mathrm{Btu} / \mathrm{h} \mathrm{ft}{ }^{\circ} \mathrm{F}\right]$} & 0,027 \\
\hline Permeability & {$[\mathrm{perm}$ in $]$} & 163,038 \\
\hline
\end{tabular}
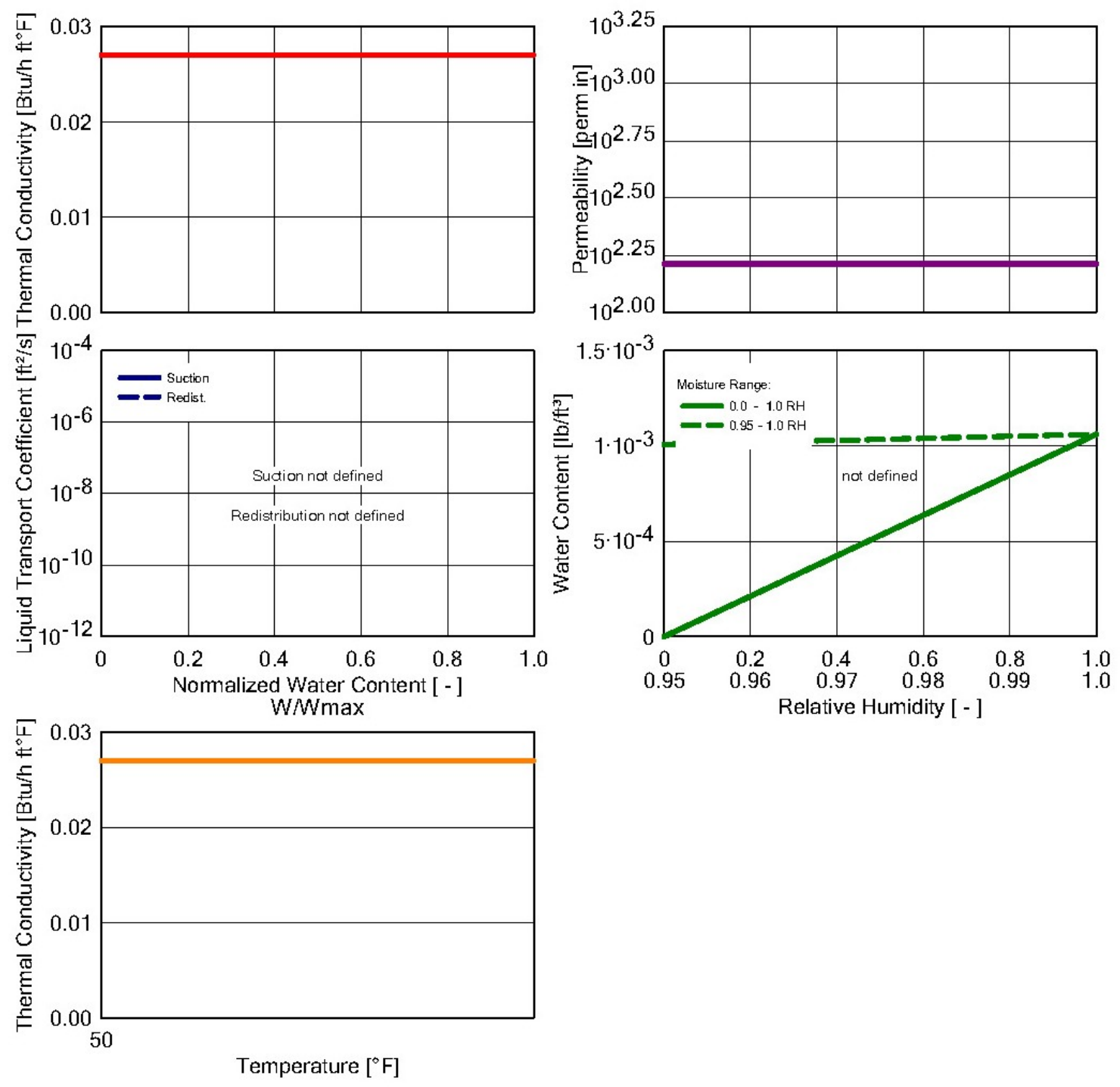
Material: Air Layer $25 \mathrm{~mm}$; without additional moisture capacity

Checking Input Data

\begin{tabular}{|l|c|c|}
\hline \multicolumn{1}{|c|}{ Property } & Unit & Value \\
\hline Bulk density & {$\left[\mathrm{lb} / \mathrm{ft}^{3}\right]$} & 0.081 \\
\hline Porosity & {$\left[\mathrm{ft}^{3} / \mathrm{ft}^{3}\right]$} & 0.999 \\
\hline Specific Heat Capacity, Dry & {$\left[\mathrm{Btu} / \mathrm{b}^{\circ} \mathrm{F}\right]$} & 0.239 \\
\hline Thermal Conductivity, Dry, $50^{\circ} \mathrm{F}$ & {$\left[\mathrm{Btu} / \mathrm{h} \mathrm{ft}{ }^{\circ} \mathrm{F}\right]$} & 0.09 \\
\hline Permeability & {$[\mathrm{perm}$ in $]$} & 252.549 \\
\hline
\end{tabular}
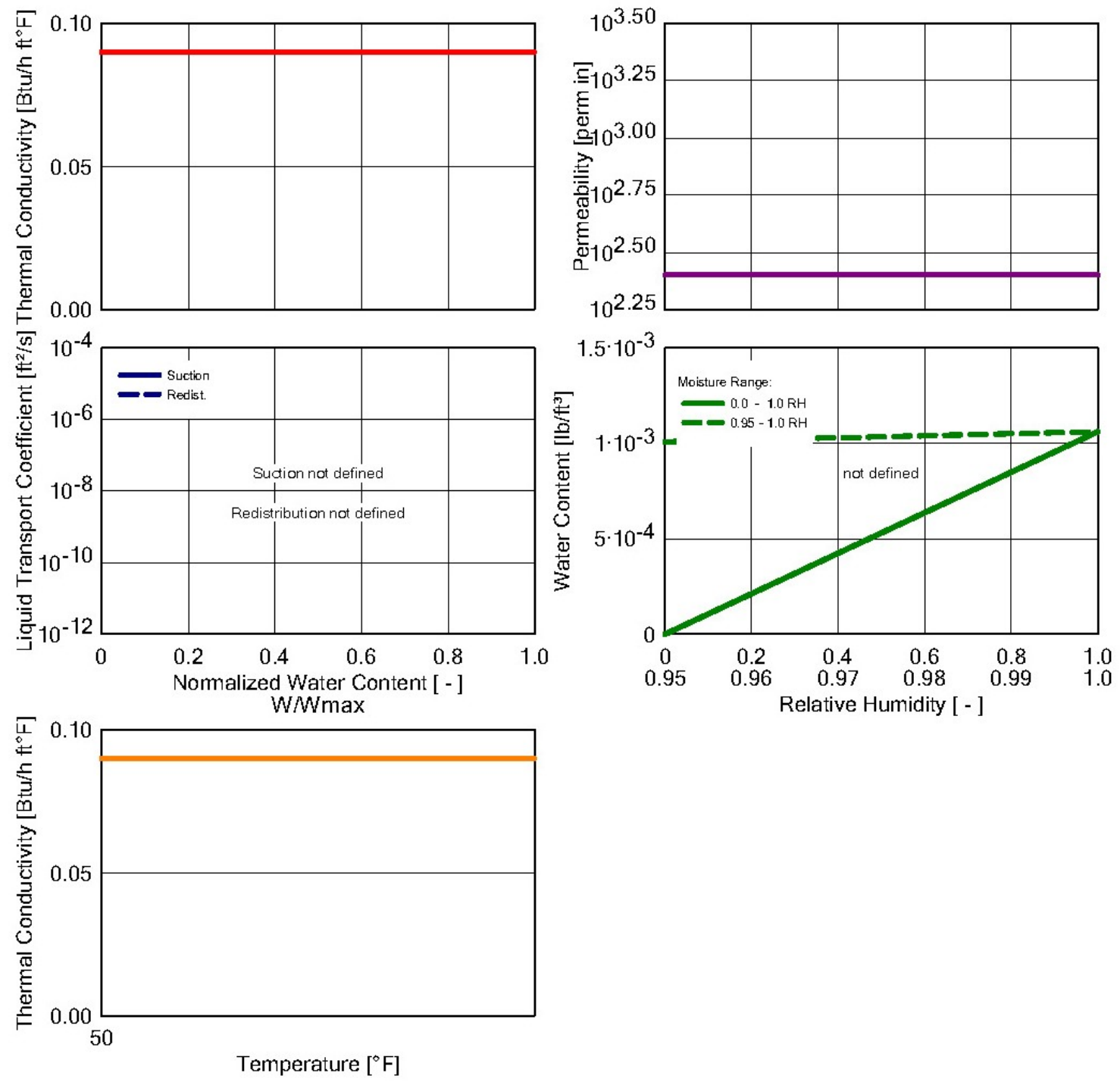
Material: Air Layer $10 \mathrm{~mm}$; without additional moisture capacity

Checking Input Data

\begin{tabular}{|l|c|c|}
\hline \multicolumn{1}{|c|}{ Property } & Unit & Value \\
\hline Bulk density & {$\left[\mathrm{lb} / \mathrm{ft}^{3}\right]$} & 0.081 \\
\hline Porosity & {$\left[\mathrm{ft}^{3} / \mathrm{ft}^{3}\right]$} & 0.999 \\
\hline Specific Heat Capacity, Dry & {$\left[\mathrm{Btu} / \mathrm{b}^{\circ} \mathrm{F}\right]$} & 0.239 \\
\hline Thermal Conductivity, Dry, $50^{\circ} \mathrm{F}$ & {$\left[\mathrm{Btu} / \mathrm{h} \mathrm{ft}{ }^{\circ} \mathrm{F}\right]$} & 0.041 \\
\hline Permeability & {$[\mathrm{perm}$ in $]$} & 176.438 \\
\hline
\end{tabular}
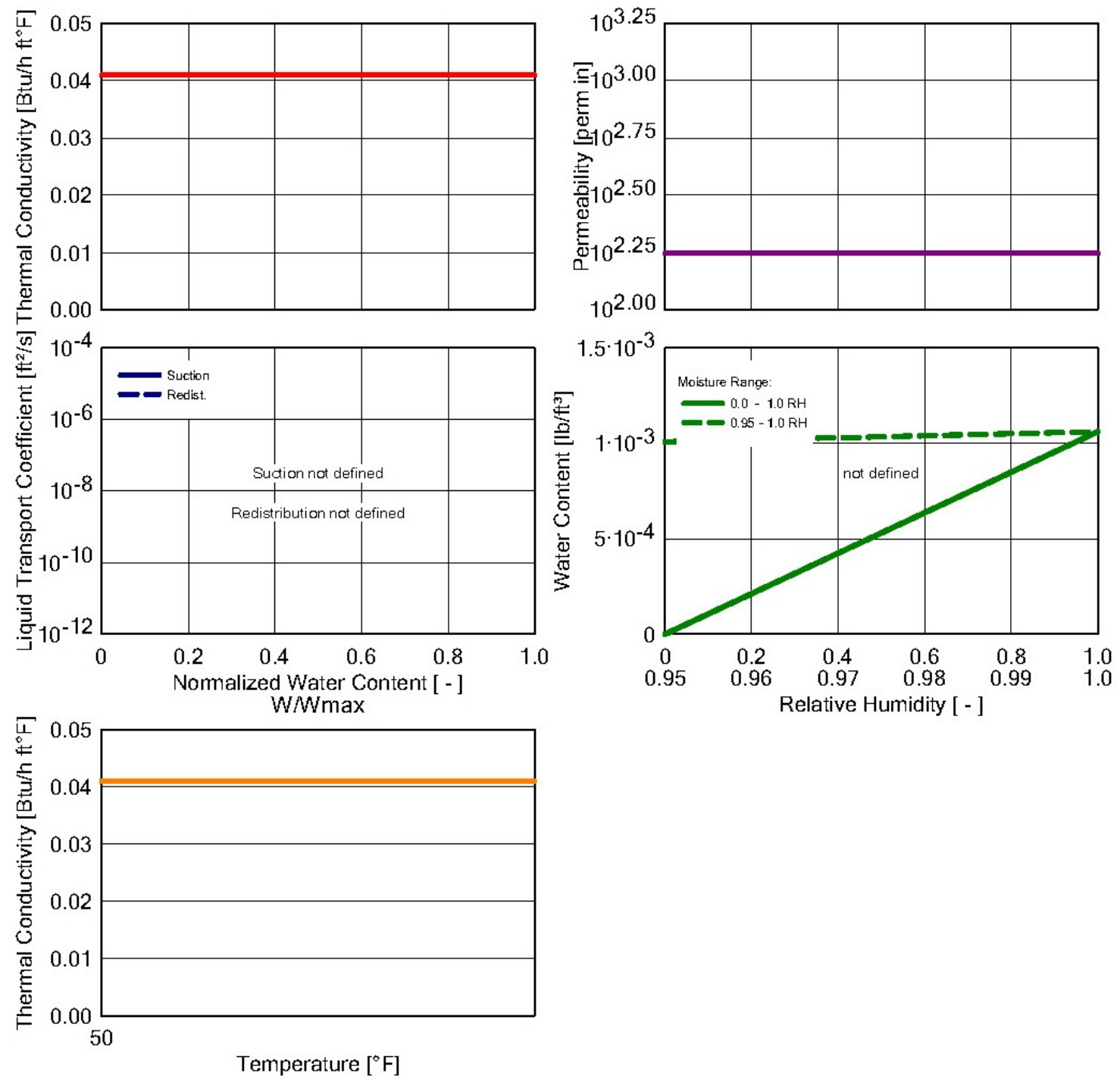
Material: *Bituminous Paper (\#15 Felt)

Checking Input Data

\begin{tabular}{|l|c|c|}
\hline \multicolumn{1}{|c|}{ Property } & Unit & Value \\
\hline Bulk density & {$\left[\mathrm{lb} / \mathrm{ft}^{3}\right]$} & 44,636 \\
\hline Porosity & {$\left[\mathrm{ft}^{3} / \mathrm{ft}^{3}\right]$} & 0,001 \\
\hline Specific Heat Capacity, Dry & {$\left[\mathrm{Btu} / \mathrm{lb}^{\circ} \mathrm{F}\right]$} & 0,358 \\
\hline Thermal Conductivity, Dry, $50^{\circ} \mathrm{F}$ & {$\left[\mathrm{Btu} / \mathrm{h} \mathrm{ft}{ }^{\circ} \mathrm{F}\right]$} & 2,311 \\
\hline Permeability & {$[\mathrm{perm}$ in] } & 0,13 \\
\hline Temp-dep. Thermal Cond. Supplement & {$\left[\mathrm{Btu} / \mathrm{h} \mathrm{ft}^{\circ} \mathrm{F}^{2}\right]$} & 0.0000640 \\
\hline
\end{tabular}
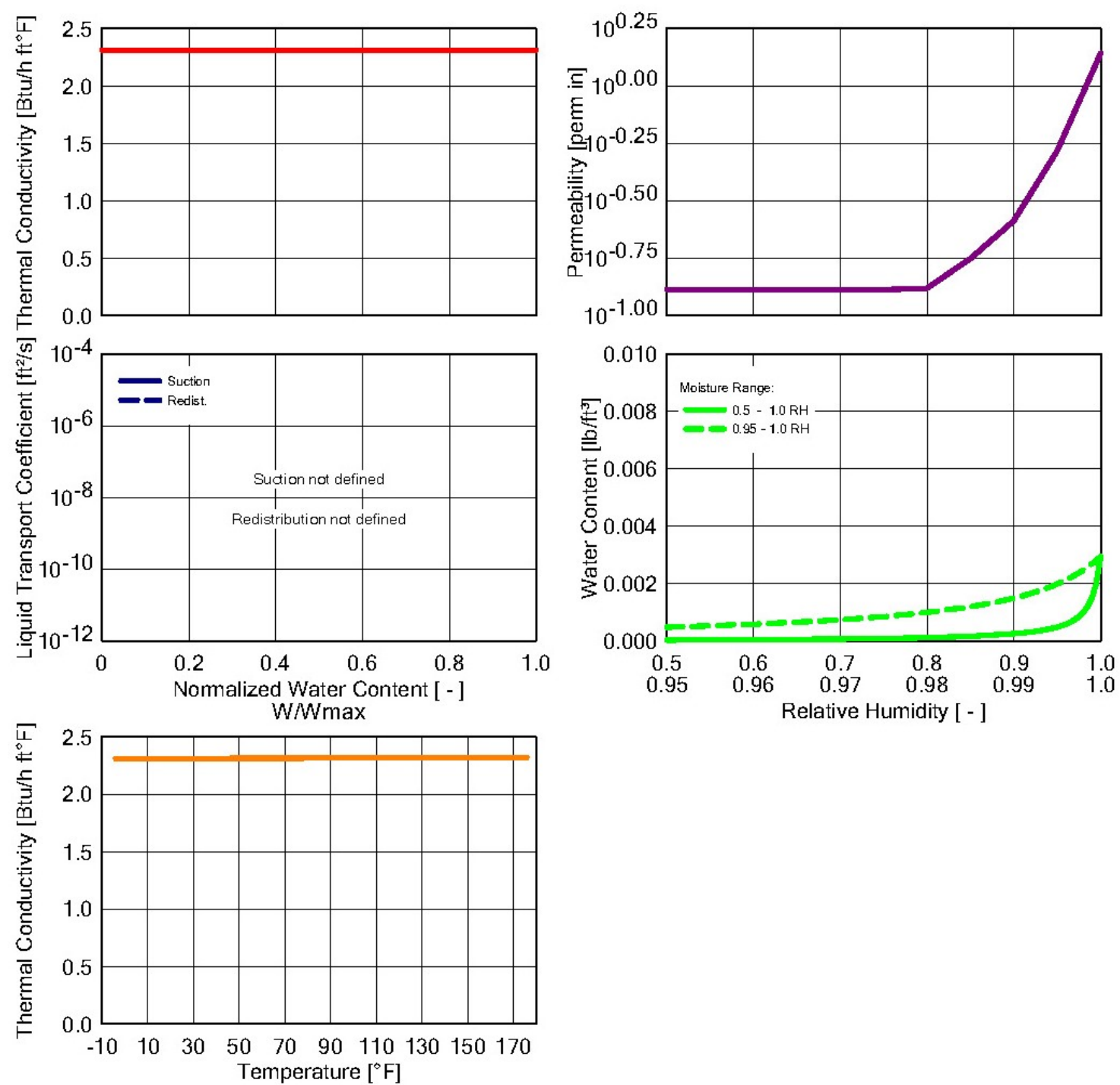
Material: Plywood high

Checking Input Data

\begin{tabular}{|l|c|c|}
\hline \multicolumn{1}{|c|}{ Property } & Unit & Value \\
\hline Bulk density & {$\left[\mathrm{lb} / \mathrm{ft}^{3}\right]$} & 37.457 \\
\hline Porosity & {$\left[\mathrm{ft}^{3} / \mathrm{ft}^{3}\right]$} & 0.96 \\
\hline Specific Heat Capacity, Dry & {$\left[\mathrm{Btu} / \mathrm{b}^{\circ} \mathrm{F}\right]$} & 0.449 \\
\hline Thermal Conductivity, Dry, 50 ${ }^{\circ} \mathrm{F}$ & {$\left[\mathrm{Btu} / \mathrm{h} \mathrm{ft}{ }^{\circ} \mathrm{F}\right]$} & 0.058 \\
\hline Permeability & {$[\mathrm{perm}$ in] } & 0.336 \\
\hline Reference Water Content & {$\left[\mathrm{lb} / \mathrm{ft}^{3}\right]$} & 5.132 \\
\hline Free Water Saturation & {$\left[\mathrm{lb} / \mathrm{ft}^{3}\right]$} & 22.1 \\
\hline Water Absorption Coefficient & {$\left[\mathrm{b} / \mathrm{in}^{2} \mathrm{~s}^{\wedge} 0.5\right]$} & 0.000004 \\
\hline Temp-dep. Thermal Cond. Supplement & {$\left[\mathrm{Btu} / \mathrm{h} \mathrm{ft}{ }^{\circ} \mathrm{F}^{2}\right]$} & 0.000064 \\
\hline
\end{tabular}
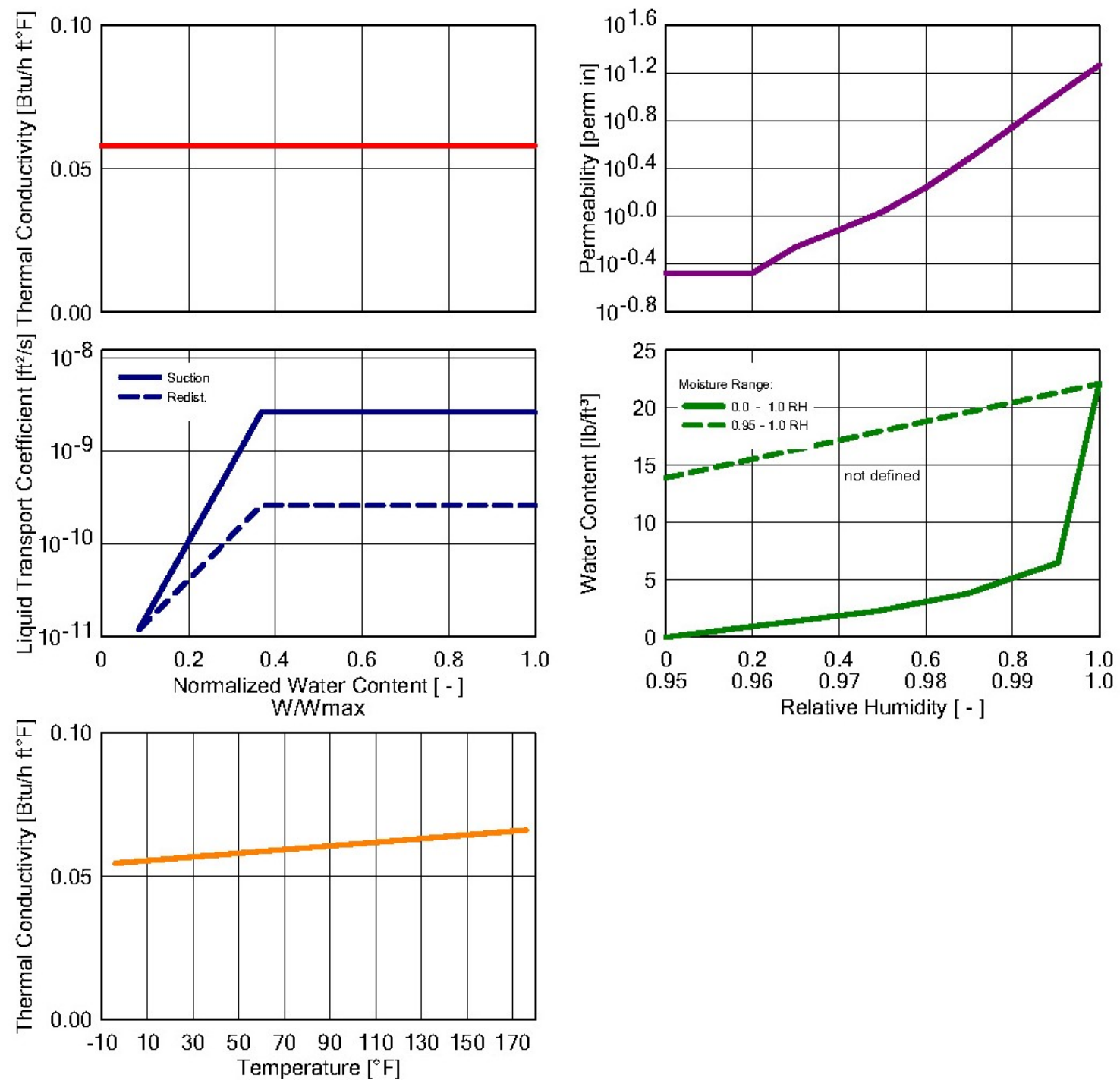
Material: Oriented Strand Board low

Checking Input Data

\begin{tabular}{|l|c|c|}
\hline \multicolumn{1}{|c|}{ Property } & Unit & Value \\
\hline Bulk density & {$\left[\mathrm{lb} / \mathrm{ft}^{3}\right]$} & 35.896 \\
\hline Porosity & {$\left[\mathrm{ft}^{3} / \mathrm{ft}^{3}\right]$} & 0.8625 \\
\hline Specific Heat Capacity, Dry & {$\left[\mathrm{Btu} / \mathrm{b}^{\circ} \mathrm{F}\right]$} & 0.449 \\
\hline Thermal Conductivity, Dry, 50 ${ }^{\circ} \mathrm{F}$ & {$\left[\mathrm{Btu} / \mathrm{h} \mathrm{ft}{ }^{\circ} \mathrm{F}\right]$} & 0.049 \\
\hline Permeability & {$[\mathrm{perm}$ in] } & 0.109 \\
\hline Reference Water Content & {$\left[\mathrm{lb} / \mathrm{ft}^{3}\right]$} & 4.451 \\
\hline Free Water Saturation & {$\left[\mathrm{lb} / \mathrm{ft}^{3}\right]$} & 20.82 \\
\hline Water Absorption Coefficient & {$\left[\mathrm{b} / \mathrm{in}^{2} \mathrm{~s}^{\wedge} 0.5\right]$} & 0.000003 \\
\hline Temp-dep. Thermal Cond. Supplement & {$\left[\mathrm{Btu} / \mathrm{h} \mathrm{ft}{ }^{\circ} \mathrm{F}^{2}\right]$} & 0.000064 \\
\hline
\end{tabular}
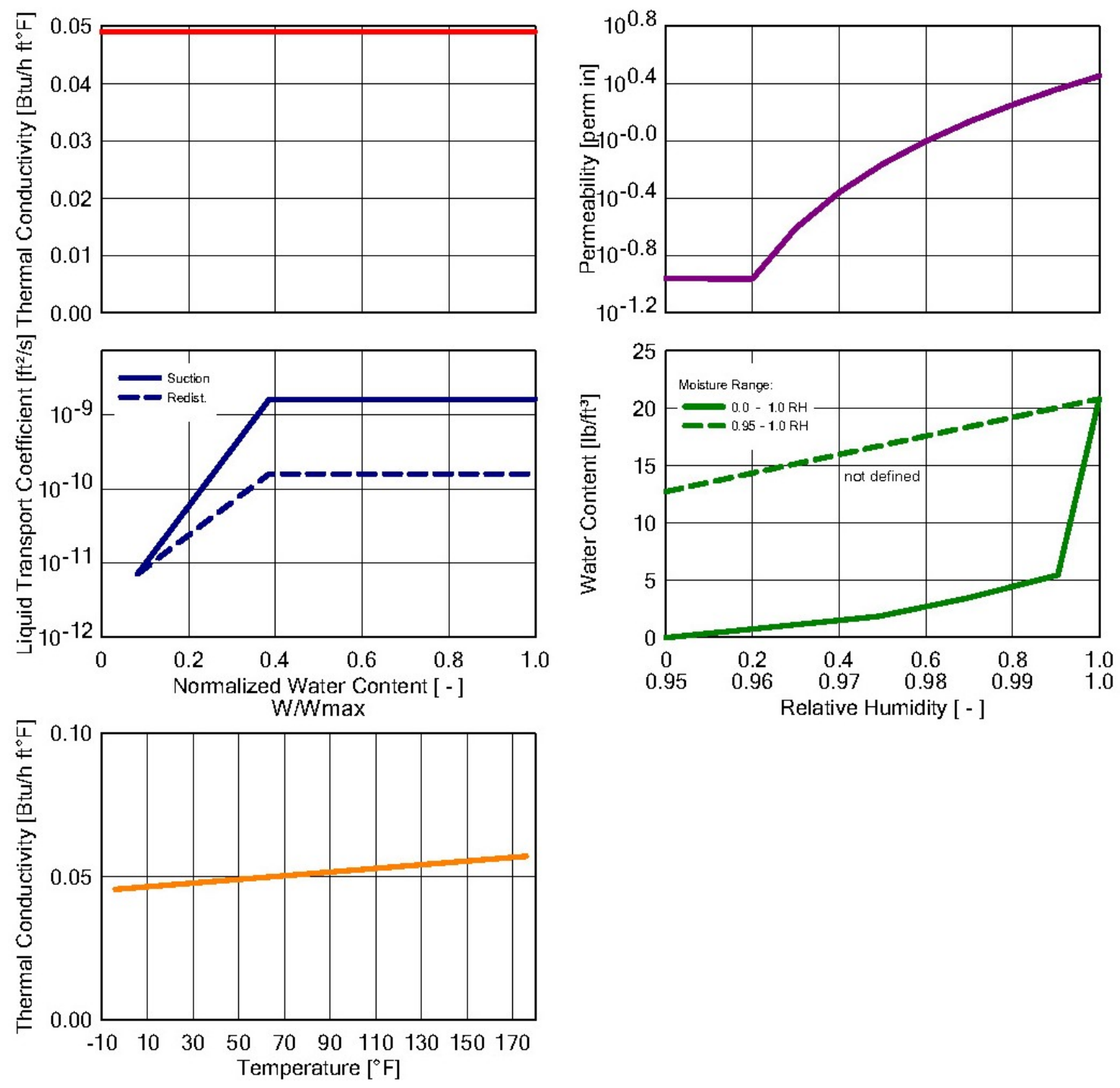
Material: *Air Layer $5 \mathrm{~mm}$

Checking Input Data

\begin{tabular}{|l|c|c|}
\hline \multicolumn{1}{|c|}{ Property } & Unit & Value \\
\hline Bulk density & {$\left[\mathrm{lb} / \mathrm{ft}^{3}\right]$} & 0,081 \\
\hline Porosity & {$\left[\mathrm{ft}^{3} / \mathrm{ft}^{3}\right]$} & 0,999 \\
\hline Specific Heat Capacity, Dry & {$\left[\mathrm{Btu} / \mathrm{b}^{\circ} \mathrm{F}\right]$} & 0,239 \\
\hline Thermal Conductivity, Dry, $50^{\circ} \mathrm{F}$ & {$\left[\mathrm{Btu} / \mathrm{h} \mathrm{ft}{ }^{\circ} \mathrm{F}\right]$} & 0,027 \\
\hline Permeability & {$[\mathrm{perm}$ in $]$} & 163,038 \\
\hline
\end{tabular}
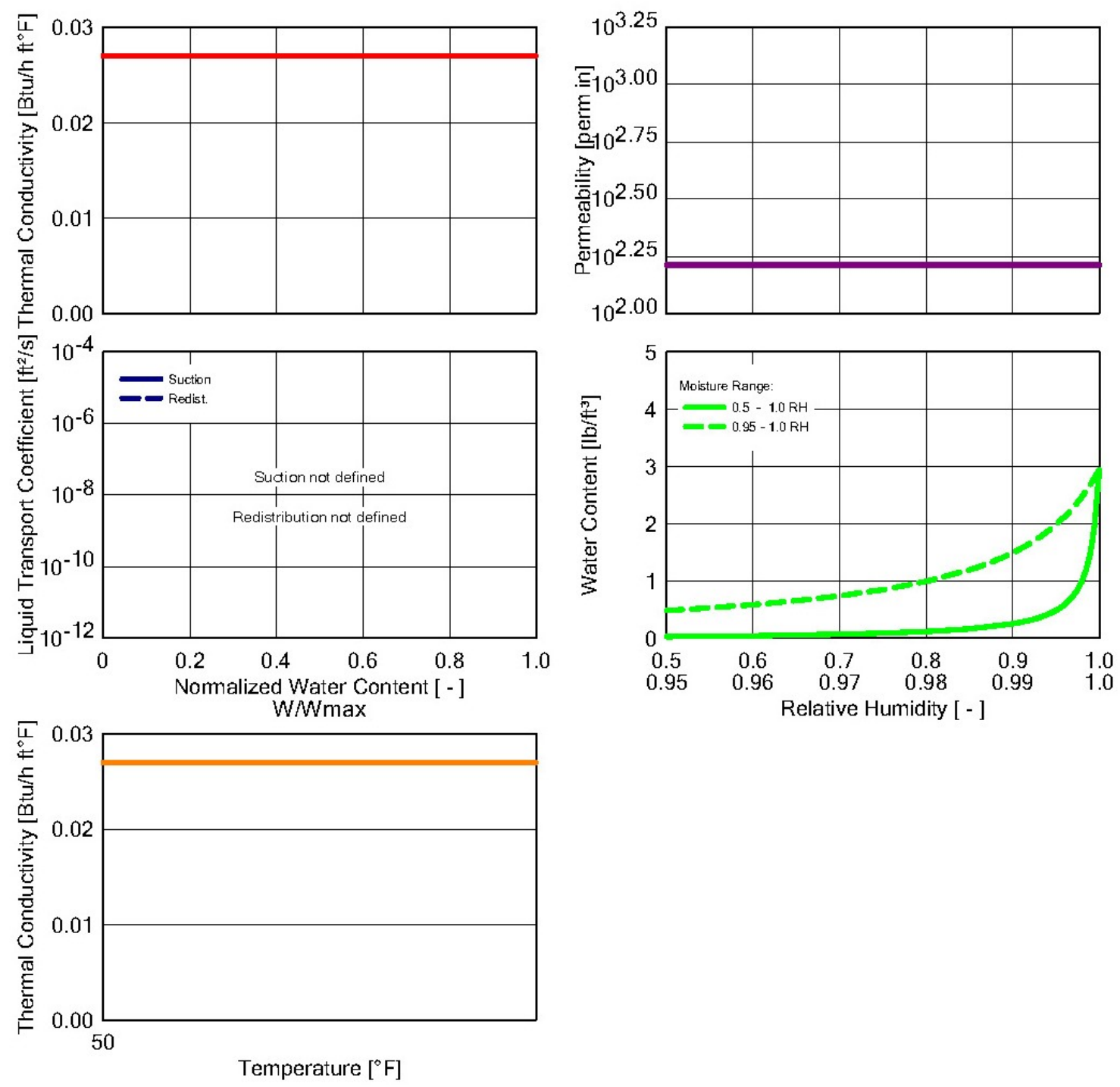
Material: *Fibre Glass (unlocked)

Checking Input Data

\begin{tabular}{|l|c|c|}
\hline \multicolumn{1}{|c|}{ Property } & Unit & Value \\
\hline Bulk density & {$\left[\mathrm{lb} / \mathrm{ft}^{3}\right]$} & 1,2 \\
\hline Porosity & {$\left[\mathrm{ft}^{3} / \mathrm{ft}^{3}\right]$} & 0,99 \\
\hline Specific Heat Capacity, Dry & {$\left[\mathrm{Btu} / \mathrm{b}^{\circ} \mathrm{F}\right]$} & 0,201 \\
\hline Thermal Conductivity, Dry, $50^{\circ} \mathrm{F}$ & {$\left[\mathrm{Btu} / \mathrm{h} \mathrm{ft}{ }^{\circ} \mathrm{F}\right]$} & 0,02 \\
\hline Permeability & {$[\mathrm{perm}$ in] } & 99,0769 \\
\hline Temp-dep. Thermal Cond. Supplement & {$\left[\mathrm{Btu} / \mathrm{h} \mathrm{ft}^{\circ} \mathrm{F}^{2}\right]$} & 0.0000640 \\
\hline
\end{tabular}
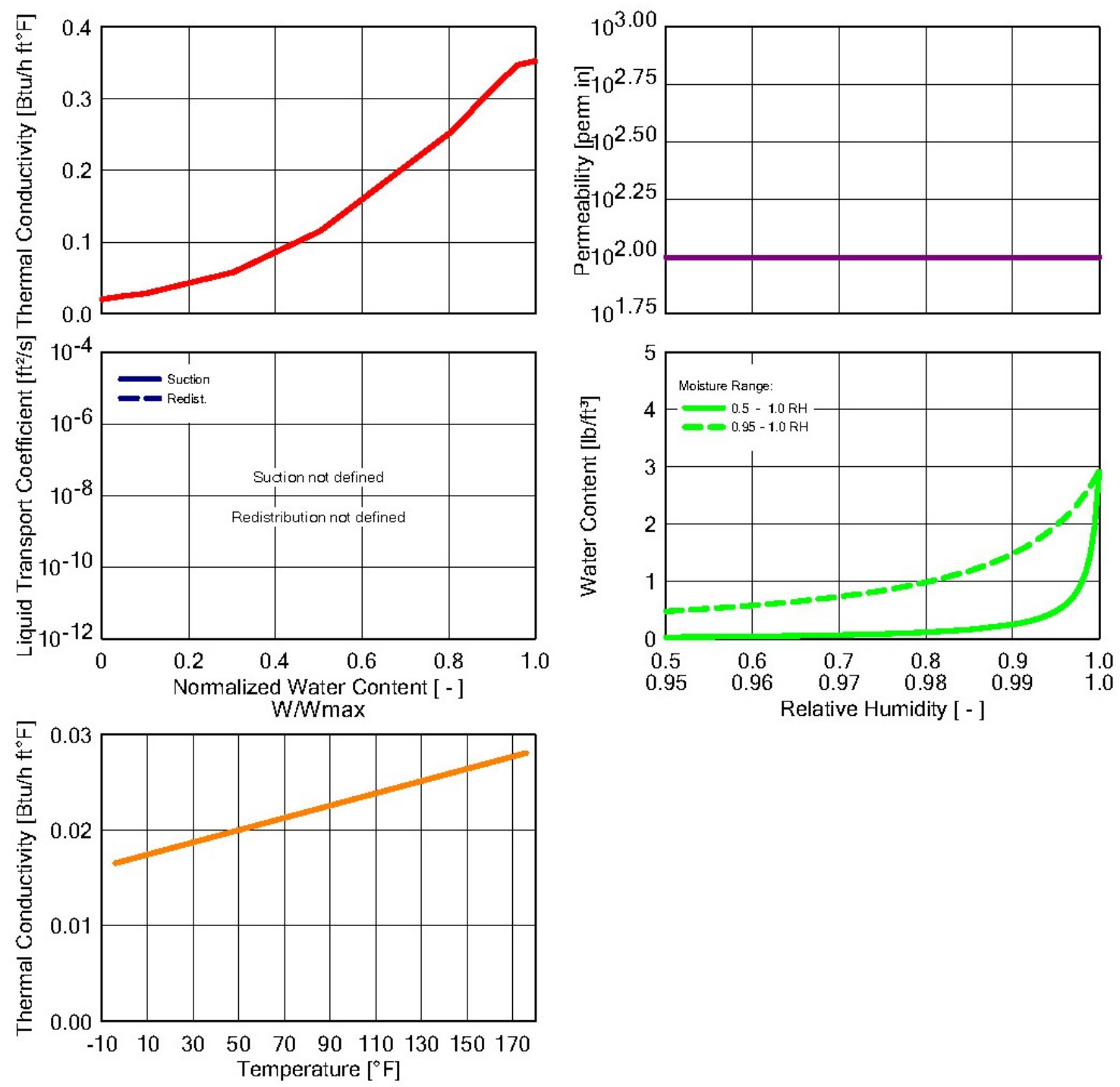


\section{Material: *(BSC) Kraft Paper}

\section{Checking Input Data}

\begin{tabular}{|l|c|c|}
\hline \multicolumn{1}{|c|}{ Property } & Unit & Value \\
\hline Bulk density & {$\left[\mathrm{lb} / \mathrm{ft}^{3}\right]$} & 7,491 \\
\hline Porosity & {$\left[\mathrm{ft}^{3} / \mathrm{ft}^{3}\right]$} & 0,6 \\
\hline Specific Heat Capacity, Dry & {$\left[\mathrm{Btu} / \mathrm{b}^{\circ} \mathrm{F}\right]$} & 0,358 \\
\hline Thermal Conductivity, Dry, $50^{\circ} \mathrm{F}$ & {$\left[\mathrm{Btu} / \mathrm{h} \mathrm{ft}{ }^{\circ} \mathrm{F}\right]$} & 0,243 \\
\hline Permeability & {$[\mathrm{perm}$ in] } & 0,035 \\
\hline Temp-dep. Thermal Cond. Supplement & {$\left[\mathrm{Btu} / \mathrm{h} \mathrm{ft}^{\circ} \mathrm{F}^{2}\right]$} & 0.0000640 \\
\hline
\end{tabular}
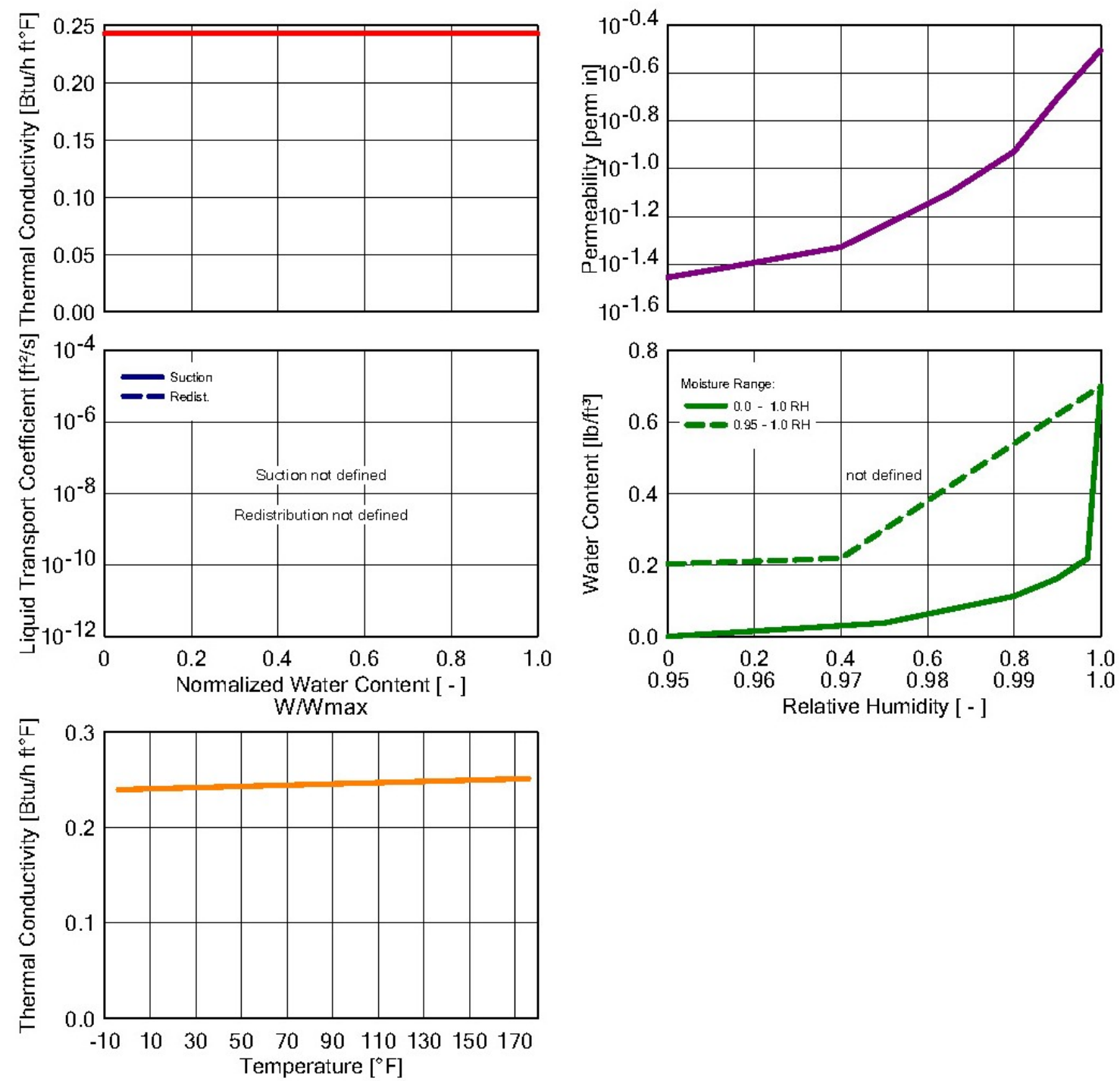
Material: vapor retarder ( 0.1 perm)

Checking Input Data

\begin{tabular}{|l|c|c|}
\hline \multicolumn{1}{|c|}{ Property } & Unit & Value \\
\hline Bulk density & {$\left[\mathrm{lb} / \mathrm{ft}^{3}\right]$} & 8.1156 \\
\hline Porosity & {$\left[\mathrm{ft}^{3} / \mathrm{ft}^{3}\right]$} & 0.001 \\
\hline Specific Heat Capacity, Dry & {$\left[\mathrm{Btu} / \mathrm{b}^{\circ} \mathrm{F}\right]$} & 0.5493 \\
\hline Thermal Conductivity, Dry, $50^{\circ} \mathrm{F}$ & {$\left[\mathrm{Btu} / \mathrm{h} \mathrm{ft}{ }^{\circ} \mathrm{F}\right]$} & 1.3289 \\
\hline Permeability & {$[\mathrm{perm}$ in] } & 0.0039 \\
\hline Temp-dep. Thermal Cond. Supplement & {$\left[\mathrm{Btu} / \mathrm{h} \mathrm{ft}^{\circ} \mathrm{F}^{2}\right]$} & 0.0000642 \\
\hline
\end{tabular}
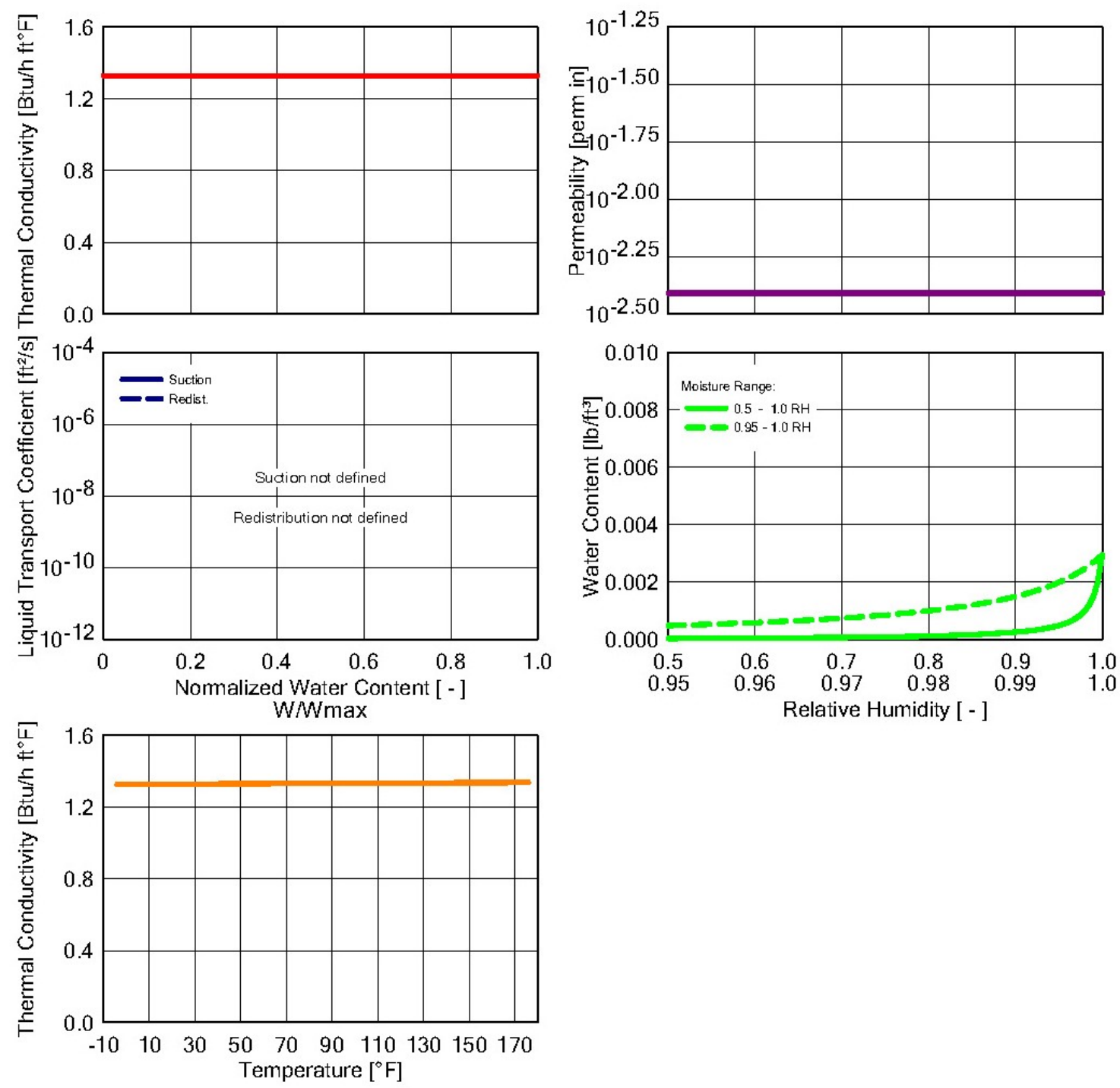
Material: *Gypsum Board (USA)

Checking Input Data

\begin{tabular}{|l|c|c|}
\hline \multicolumn{1}{|c|}{ Property } & Unit & Value \\
\hline Bulk density & {$\left[\mathrm{lb} / \mathrm{ft}^{3}\right]$} & 53,064 \\
\hline Porosity & {$\left[\mathrm{ft}^{3} / \mathrm{ft}^{3}\right]$} & 0,65 \\
\hline Specific Heat Capacity, Dry & {$\left[\mathrm{Btu} / \mathrm{b}^{\circ} \mathrm{F}\right]$} & 0,208 \\
\hline Thermal Conductivity, Dry, $50^{\circ} \mathrm{F}$ & {$\left[\mathrm{Btu} / \mathrm{h} \mathrm{ft}{ }^{\circ} \mathrm{F}\right]$} & 0,094 \\
\hline Permeability & {$[\mathrm{perm}$ in] } & 21,467 \\
\hline Moisture-dep. Thermal Cond. Supplement & {$[\% / \mathrm{M} .-\%]$} & 8,0 \\
\hline Temp-dep. Thermal Cond. Supplement & {$\left[\mathrm{Btu} / \mathrm{htt}^{\circ} \mathrm{F}^{2}\right]$} & 0.0000640 \\
\hline
\end{tabular}
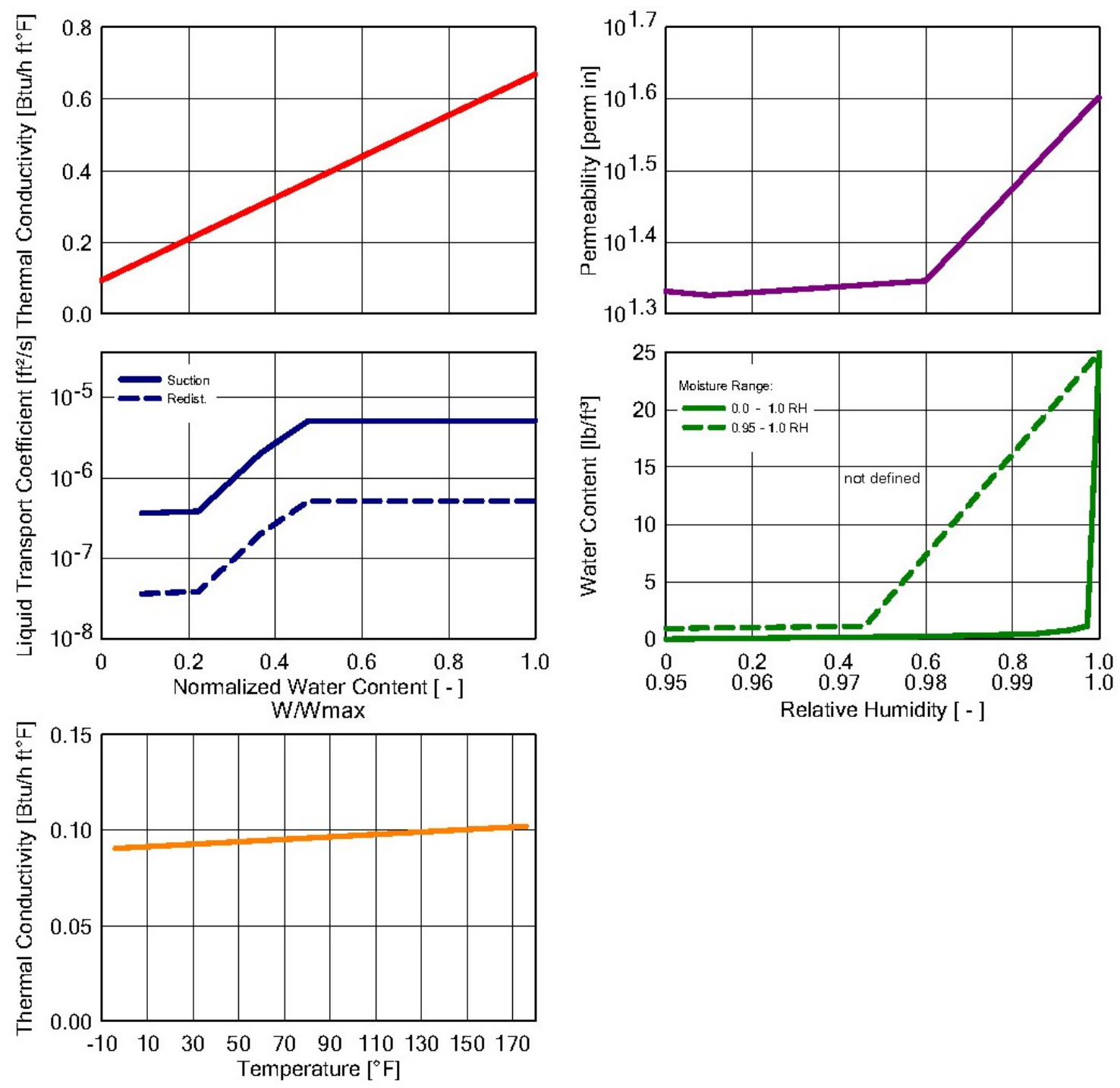


\section{Appendix C. WUFI Surface Transfer Coefficients}

Exterior (Left Side)

\begin{tabular}{|c|c|c|c|}
\hline Name & Description & Unit & Value \\
\hline $\begin{array}{l}\text { Heat Resistance } \\
\text { - includes long-wave radiation }\end{array}$ & External Wall & {$\left[\mathrm{h} \mathrm{ft}{ }^{2} \mathrm{~F} / \mathrm{Btu}\right]$} & $\begin{array}{c}0,3339 \\
\text { yes }\end{array}$ \\
\hline Permeance & No coating & [perm] & ---- \\
\hline Short-Wave Radiation Absorptivity & Stucco, dark (aged) & {$[-]$} & 0.6 \\
\hline Long-Wave Radiation Emissivity & Stucco, dark (aged) & {$[-]$} & 0.9 \\
\hline Adhering Fraction of Rain & \multicolumn{3}{|c|}{ According to inclination and consjruction t9p队e } \\
\hline Explicit Radiation Balance & & & no \\
\hline
\end{tabular}

Interior (Right Side)

\begin{tabular}{|l|l|c|c|}
\hline \multicolumn{1}{|c|}{ Name } & \multicolumn{1}{c|}{ Description } & Unit & Value \\
\hline Heat Resistance & External Wall & {$\left[\mathrm{h} \mathrm{ft}^{2}{ }^{\circ} \mathrm{F} / \mathrm{Btu}\right]$} & 0,7098 \\
\hline Permeance & & {$[\mathrm{perm}]$} & 10,0 \\
\hline
\end{tabular}




\section{Appendix D. WUFI Source, Sinks}

\section{Wall 1 (Wood Siding-Ply)}

*Southern Yellow Pine

\begin{tabular}{|l|l|c|c|}
\hline \multicolumn{3}{|c|}{ Type } \\
\hline \multirow{4}{*}{ Rain Leak @ back of claddingoisture Source } & {$[\mathrm{in}]$} & 0,1181 \\
\cline { 2 - 4 } & Depth in Layer & {$\left[\mathrm{b} / \mathrm{ft}^{3}\right]$} & 18,728 \\
\cline { 2 - 4 } & Cut-Off at Free Water Saturation & {$[\%]$} & 1 \\
\cline { 2 - 5 } & Fraction of Driving Rain & {$[\%]$} & \\
\hline
\end{tabular}

*Air Layer 5 mm; without additional moisture capacity

\begin{tabular}{|l|l|c|c|}
\hline \multicolumn{1}{|c|}{ Name } & \multicolumn{3}{|c|}{ Type } \\
\hline \multirow{4}{*}{ Ventilation } & \multicolumn{2}{|c|}{ Air Change Source } \\
\cline { 2 - 4 } & Whole Layer & {$[1 / \mathrm{h}]$} & 20 \\
\cline { 2 - 4 } & mix with air from left-hand side & \multicolumn{3}{|c|}{} \\
\cline { 2 - 4 } & Air Changes &
\end{tabular}

Plywood high

\begin{tabular}{|l|l|c|c|}
\hline \multirow{2}{|c|}{ Name } & \multicolumn{3}{|c|}{ Type } \\
\hline Rain Leak @ Shthg & Moisture Source & {$[\mathrm{in}]$} & 0,0118 \\
\cline { 2 - 4 } & Depth in Layer & {$\left[\mathrm{lb} / \mathrm{ft}^{3}\right]$} & 22.1 \\
\cline { 2 - 4 } & Cut-Off at Free Water Saturation & {$[\%]$} & 0.01 \\
\cline { 2 - 4 } & Fraction of Driving Rain &
\end{tabular}

*Air Layer 5 mm

\begin{tabular}{|l|l|c|c|}
\hline \multicolumn{1}{|c|}{ Name } & \multicolumn{3}{|c|}{ Type } \\
\hline Stud Space Ventilation & \multicolumn{2}{|l|}{ Air Change Source } \\
\cline { 2 - 4 } & Whole Layer & {$[1 / \mathrm{h}]$} & 10 \\
\cline { 2 - 4 } & mix with air from left-hand side & \\
\cline { 2 - 4 } & Air Changes &
\end{tabular}


*Air Layer 5 mm

\begin{tabular}{|c|c|c|c|}
\hline Name & \multicolumn{3}{|c|}{ Type } \\
\hline \multirow[t]{4}{*}{ Air Leak } & \multicolumn{3}{|l|}{ Air Change Source } \\
\hline & \multicolumn{3}{|l|}{ Whole Layer } \\
\hline & \multicolumn{3}{|l|}{ mix with air from right-hand side } \\
\hline & Air Changes & {$[1 / \mathrm{h}]$} & 10 \\
\hline
\end{tabular}




\section{Wall 2 (Vinyl Siding-Ply)}

Air Layer $5 \mathrm{~mm}$; without additional moisture capacity

\begin{tabular}{|l|l|c|c|}
\hline \multicolumn{3}{|c|}{ Type } \\
\hline \multirow{4}{*}{ Rain Leak @ back of claddingoisture Source } \\
\cline { 2 - 4 } & Whole Layer & {$\left[\mathrm{lb} / \mathrm{ft}^{3}\right]$} & \\
\cline { 2 - 4 } & Cut-Off at Free Water Saturation & {$[\%]$} & 1 \\
\cline { 2 - 4 } & Fraction of Driving Rain & \\
\hline
\end{tabular}

*Air Layer $5 \mathrm{~mm}$; without additional moisture capacity

\begin{tabular}{|l|l|c|c|}
\hline \multicolumn{1}{|c|}{ Name } & \multicolumn{3}{|c|}{ Type } \\
\hline \multirow{3}{*}{ Ventilation } & \multicolumn{2}{|c|}{ Air Change Source } \\
\cline { 2 - 4 } & Whole Layer & {$[1 / \mathrm{h}]$} & 200 \\
\cline { 2 - 4 } & mix with air from left-hand side & \\
\cline { 2 - 4 } & Air Changes &
\end{tabular}

Plywood high

\begin{tabular}{|l|l|c|c|}
\hline \multicolumn{3}{|c|}{ Name } & \multicolumn{3}{|c|}{} \\
\hline Rain Leak @ Shthg & Moisture Source & {$[\mathrm{in}]$} & 0,0118 \\
\cline { 2 - 4 } & Depth in Layer & {$\left[\mathrm{lb} / \mathrm{ft}^{3}\right]$} & 22.1 \\
\cline { 2 - 4 } & Cut-Off at Free Water Saturation & {$[\%]$} & 0.01 \\
\cline { 2 - 4 } & Fraction of Driving Rain & {$[\%]$}
\end{tabular}

*Air Layer 5 mm

\begin{tabular}{|c|c|c|c|}
\hline Name & \multicolumn{3}{|c|}{ Type } \\
\hline \multirow[t]{4}{*}{ Stud Space Ventilation } & \multicolumn{3}{|l|}{ Air Change Source } \\
\hline & \multicolumn{3}{|l|}{ Whole Layer } \\
\hline & \multicolumn{3}{|l|}{ mix with air from left-hand side } \\
\hline & Air Changes & {$[1 / \mathrm{h}]$} & 10 \\
\hline
\end{tabular}

*Air Layer 5 mm

\begin{tabular}{|c|c|c|c|}
\hline Name & Typ & & \\
\hline \multirow[t]{4}{*}{ Air Leak } & \multicolumn{3}{|l|}{ Air Change Source } \\
\hline & \multicolumn{3}{|l|}{ Whole Layer } \\
\hline & \multicolumn{3}{|l|}{ mix with air from right-hand side } \\
\hline & Air Changes & {$[1 / \mathrm{h}]$} & 10 \\
\hline
\end{tabular}




\section{Wall 3 (Vinyl-OSB)}

Air Layer $5 \mathrm{~mm}$; without additional moisture capacity

\begin{tabular}{|l|l|c|c|}
\hline \multicolumn{3}{|c|}{ Type } \\
\hline \multirow{4}{*}{ Rain Leak @ back of claddingoisture Source } \\
\cline { 2 - 4 } & Whole Layer & {$\left[\mathrm{lb} / \mathrm{ft}^{3}\right]$} & \\
\cline { 2 - 4 } & Cut-Off at Free Water Saturation & {$[\%]$} & 1 \\
\cline { 2 - 4 } & Fraction of Driving Rain & \\
\hline
\end{tabular}

*Air Layer $5 \mathrm{~mm}$; without additional moisture capacity

\begin{tabular}{|l|l|c|c|}
\hline \multicolumn{1}{|c|}{ Name } & \multicolumn{3}{|c|}{ Type } \\
\hline \multirow{3}{*}{ Ventilation } & \multicolumn{2}{|c|}{ Air Change Source } \\
\cline { 2 - 4 } & Whole Layer & {$[1 / \mathrm{h}]$} & 200 \\
\cline { 2 - 4 } & mix with air from left-hand side & \\
\cline { 2 - 4 } & Air Changes &
\end{tabular}

\section{Oriented Strand Board low}

\begin{tabular}{|l|l|c|c|}
\hline \multirow{2}{|c|}{ Name } & \multicolumn{3}{|c|}{ Type } \\
\hline Rain Leak @ Shthg & Moisture Source & {$[\mathrm{in}]$} & 0,0118 \\
\cline { 2 - 4 } & Depth in Layer & {$\left[\mathrm{b} / \mathrm{ft}^{3}\right]$} & 20.82 \\
\cline { 2 - 4 } & Cut-Off at Free Water Saturation & {$[\%]$} & 0.01 \\
\cline { 2 - 4 } & Fraction of Driving Rain &
\end{tabular}

*Air Layer 5 mm

\begin{tabular}{|c|c|c|c|}
\hline Name & \multicolumn{3}{|c|}{ Type } \\
\hline \multirow[t]{4}{*}{ Stud Space Ventilation } & \multicolumn{3}{|l|}{ Air Change Source } \\
\hline & \multicolumn{3}{|l|}{ Whole Layer } \\
\hline & \multicolumn{3}{|l|}{ mix with air from left-hand side } \\
\hline & Air Changes & {$[1 / \mathrm{h}]$} & 10 \\
\hline
\end{tabular}

*Air Layer 5 mm

\begin{tabular}{|c|c|c|c|}
\hline Name & \multicolumn{3}{|c|}{ Type } \\
\hline \multirow[t]{4}{*}{ Air Leak } & \multicolumn{3}{|l|}{ Air Change Source } \\
\hline & \multicolumn{3}{|l|}{ Whole Layer } \\
\hline & \multicolumn{3}{|l|}{ mix with air from right-hand side } \\
\hline & Air Changes & {$[1 / \mathrm{h}]$} & 10 \\
\hline
\end{tabular}




\section{Wall 4 (Brick-OSB)}

\section{Solid Brick Masonry}

\begin{tabular}{|l|l|c|c|}
\hline \multicolumn{3}{|c|}{ Type } \\
\hline \multirow{4}{*}{ Rain Leak @ back of claddirgoisture Source } & {$[\mathrm{in}]$} & 3 \\
\cline { 2 - 4 } & Start Depth in Layer & {$[\mathrm{in}]$} & 3.5 \\
\cline { 2 - 4 } & End Depth in Layer & {$\left[\mathrm{lb} / \mathrm{ft}^{3}\right]$} & 11.861 \\
\cline { 2 - 4 } & Cut-Off at Free Water Saturation & {$[\%]$} & 1 \\
\cline { 2 - 4 } & Fraction of Driving Rain &
\end{tabular}

Air Layer 25 mm; without additional moisture capacity

\begin{tabular}{|c|c|c|c|}
\hline Name & \multicolumn{3}{|c|}{ Type } \\
\hline \multirow[t]{4}{*}{ Ventilation } & \multicolumn{3}{|l|}{ Air Change Source } \\
\hline & \multicolumn{3}{|l|}{ Whole Layer } \\
\hline & \multicolumn{3}{|l|}{ mix with air from left-hand side } \\
\hline & Air Changes & {$[1 / \mathrm{h}]$} & 10 \\
\hline
\end{tabular}

\section{Oriented Strand Board low}

\begin{tabular}{|l|l|c|c|}
\hline \multicolumn{3}{|c|}{ Name } & \multicolumn{3}{|c|}{ Type } \\
\hline \multirow{4}{*}{ Rain Leak @ Shthg } & Moisture Source & {$[\mathrm{in}]$} & 0,0118 \\
\cline { 2 - 4 } & Depth in Layer & {$\left[\mathrm{b} / \mathrm{ft}^{3}\right]$} & 20.82 \\
\cline { 2 - 4 } & Cut-Off at Free Water Saturation & {$[\%]$} & 0.01 \\
\cline { 2 - 4 } & Fraction of Driving Rain & {$[\%$} & \\
\hline
\end{tabular}

"Air Layer 5 mm

\begin{tabular}{|c|c|c|c|}
\hline Name & \multicolumn{3}{|c|}{ Type } \\
\hline \multirow[t]{4}{*}{ Stud Space Ventilation } & \multicolumn{3}{|l|}{ Air Change Source } \\
\hline & \multicolumn{3}{|l|}{ Whole Layer } \\
\hline & \multicolumn{3}{|l|}{ mix with air from left-hand side } \\
\hline & Air Changes & {$[1 / \mathrm{h}]$} & 10 \\
\hline
\end{tabular}

*Air Layer 5 mm

\begin{tabular}{|c|c|c|c|}
\hline Name & \multicolumn{3}{|c|}{ Type } \\
\hline \multirow[t]{4}{*}{ Air Leak } & \multicolumn{3}{|l|}{ Air Change Source } \\
\hline & \multicolumn{3}{|l|}{ Whole Layer } \\
\hline & \multicolumn{3}{|l|}{ mix with air from right-hand side } \\
\hline & Air Changes & {$[1 / \mathrm{h}]$} & 10 \\
\hline
\end{tabular}




\section{Wall 5 (Stucco-OSB)}

Regular Portland Stucco

\begin{tabular}{|l|l|c|c|}
\hline \multicolumn{2}{|c|}{ Type } \\
\hline \multirow{4}{*}{ Rain Leak @ back of claddiolgoisture Source } & {$[\mathrm{in}]$} & 0.5 \\
\cline { 2 - 4 } & Start Depth in Layer & {$[\mathrm{in}]$} & 0.75 \\
\cline { 2 - 4 } & End Depth in Layer & {$\left[\mathrm{lb} / \mathrm{ft}^{3}\right]$} & \\
\cline { 2 - 4 } & Cut-Off at Free Water Saturation & {$[\%]$} & 1 \\
\cline { 2 - 4 } & Fraction of Driving Rain & \multicolumn{1}{|c|}{1} \\
\hline
\end{tabular}

Oriented Strand Board low

\begin{tabular}{|l|l|c|c|}
\hline \multicolumn{3}{|c|}{ Name } & \multicolumn{3}{|c|}{ Type } \\
\hline \multirow{4}{*}{ Rain Leak @ Shthg } & Moisture Source & {$[\mathrm{in}]$} & 0,0118 \\
\cline { 2 - 4 } & Depth in Layer & {$\left[\mathrm{lb} / \mathrm{ft}^{3}\right]$} & 20.82 \\
\cline { 2 - 4 } & Cut-Off at Free Water Saturation & {$[\%]$} & 0.01 \\
\cline { 2 - 4 } & Fraction of Driving Rain & \multicolumn{3}{|c|}{} \\
\hline
\end{tabular}

"Air Layer 5 mm

\begin{tabular}{|c|c|c|c|}
\hline Name & \multicolumn{3}{|c|}{ Type } \\
\hline \multirow[t]{4}{*}{ Stud Space Ventilation } & \multicolumn{3}{|l|}{ Air Change Source } \\
\hline & \multicolumn{3}{|l|}{ Whole Layer } \\
\hline & \multicolumn{3}{|l|}{ mix with air from left-hand side } \\
\hline & Air Changes & {$[1 / h]$} & 10 \\
\hline
\end{tabular}

*Air Layer 5 mm

\begin{tabular}{|c|c|c|c|}
\hline Name & \multicolumn{3}{|c|}{ Type } \\
\hline \multirow[t]{4}{*}{ Air Leak } & \multicolumn{3}{|c|}{ Air Change Source } \\
\hline & \multicolumn{3}{|c|}{ Whole Layer } \\
\hline & \multicolumn{3}{|c|}{ mix with air from right-hand side } \\
\hline & Air Changes & {$[1 / \mathrm{h}]$} & 10 \\
\hline
\end{tabular}




\section{Wall 6 (Vented Stucco-OSB)}

Regular Portland Stucco

\begin{tabular}{|l|l|c|c|}
\hline \multicolumn{2}{|c|}{ Type } \\
\hline \multirow{4}{*}{ Rain Leak @ back of claddirlgoisture Source } & {$[\mathrm{in}]$} & 0.5 \\
\cline { 2 - 4 } & Start Depth in Layer & {$[\mathrm{in}]$} & 0.75 \\
\cline { 2 - 4 } & End Depth in Layer & {$\left[\mathrm{lb} / \mathrm{ft}^{3}\right]$} & \\
\cline { 2 - 4 } & Cut-Off at Free Water Saturation & {$[\%]$} & 1 \\
\cline { 2 - 4 } & Fraction of Driving Rain & {$[\%]$} & 1 \\
\hline
\end{tabular}

Air Layer $10 \mathrm{~mm}$; without additional moisture capacity

\begin{tabular}{|l|l|c|l|}
\hline \multicolumn{2}{|c|}{ Name } & \multicolumn{3}{|c|}{ Type } \\
\hline \multirow{4}{*}{ Ventilation } & \multicolumn{2}{|c|}{ Air Change Source } \\
\cline { 2 - 4 } & Whole Layer & {$[1 / \mathrm{h}]$} & 10 \\
\cline { 2 - 4 } & mix with air from left-hand side & \multicolumn{2}{|c|}{10} \\
\cline { 2 - 4 } & Air Changes &
\end{tabular}

\section{Oriented Strand Board low}

\begin{tabular}{|l|l|c|c|}
\hline \multicolumn{3}{|c|}{ Name } & \multicolumn{3}{|c|}{ Type } \\
\hline \multirow{4}{*}{ Rain Leak @ Shthg } & Moisture Source & {$[\mathrm{in}]$} & 0,0118 \\
\cline { 2 - 4 } & Depth in Layer & {$\left[\mathrm{b} / \mathrm{ft}^{3}\right]$} & 20.82 \\
\cline { 2 - 4 } & Cut-Off at Free Water Saturation & {$[\%]$} & 0.01 \\
\cline { 2 - 4 } & Fraction of Driving Rain & \multicolumn{3}{|c|}{} \\
\end{tabular}

*Air Layer 5 mm

\begin{tabular}{|c|c|c|c|}
\hline Name & \multicolumn{3}{|c|}{ Type } \\
\hline \multirow[t]{4}{*}{ Stud Space Ventilation } & \multicolumn{3}{|l|}{ Air Change Source } \\
\hline & \multicolumn{3}{|l|}{ Whole Layer } \\
\hline & \multicolumn{3}{|l|}{ mix with air from left-hand side } \\
\hline & Air Changes & {$[1 / \mathrm{h}]$} & 10 \\
\hline
\end{tabular}

*Air Layer 5 mm

\begin{tabular}{|c|c|c|c|}
\hline Name & \multicolumn{3}{|c|}{ Type } \\
\hline \multirow[t]{4}{*}{ Air Leak } & \multicolumn{3}{|l|}{ Air Change Source } \\
\hline & \multicolumn{3}{|l|}{ Whole Layer } \\
\hline & \multicolumn{3}{|l|}{ mix with air from right-hand side } \\
\hline & Air Changes & {$[1 / \mathrm{h}]$} & 10 \\
\hline
\end{tabular}


